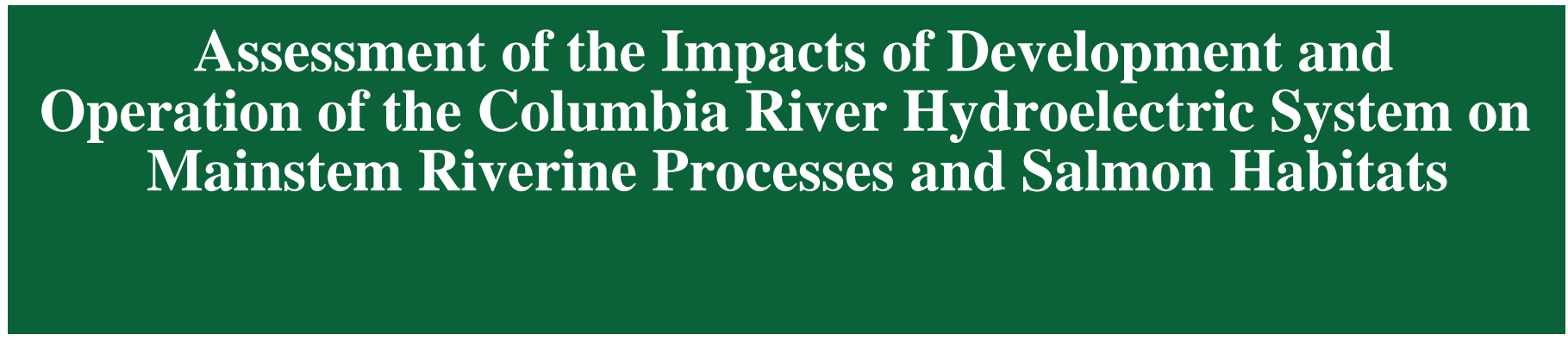

Final Report

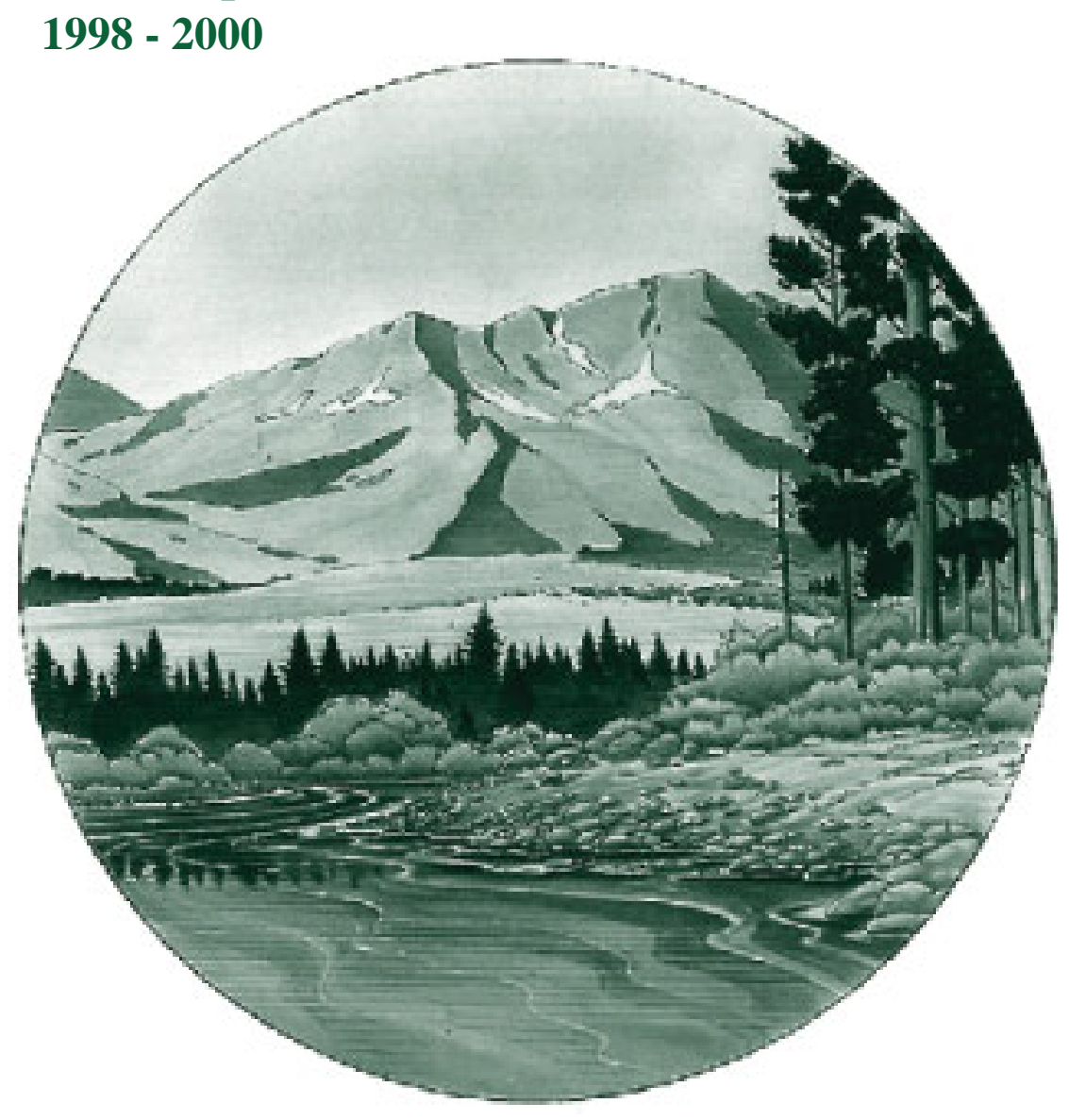

DOE/BP-08104-1

December 2000 
This Document should be cited as follows:

Dauble, Dennis, Columbia River Research Laboratory, "Assessment of the Impacts of Development and Operation of the Columbia River Hydroelectric System on Mainstem Riverine Processes and Salmon Habitats", 1998-2000 Final Report, Project No. 199800402, 148 electronic pages, (BPA Report DOE/BP-08104-1)

\author{
Bonneville Power Administration \\ P.O. Box 3621 \\ Portland, OR 97208
}

This report was funded by the Bonneville Power Administration (BPA), U.S. Department of Energy, as part of BPA's program to protect, mitigate, and enhance fish and wildlife affected by the development and operation of hydroelectric facilities on the Columbia River and its tributaries. The views in this report are the author's and do not necessarily represent the views of BPA. 


\title{
ASSESSMENT OF THE IMPACTS OF DEVELOPMENT AND OPERATION OF THE COLUMBIA RIVER HYDROELECTRIC SYSTEM ON MAINSTEM RIVERINE PROCESSES AND SALMON HABITATS
}

\author{
Prepared by \\ Battelle's Pacific Northwest Division \\ Richland, Washington \\ and \\ U.S. Geological Survey, Biological Resources Division \\ Cook, Washington \\ Prepared for \\ Bonneville Power Administration \\ Division of Fish and Wildlife \\ Portland, Oregon
}

June 2000 


\section{SUMMARY}

This report consists of three separate, but closely related, studies designed to address overall goals of the project, which were to: 1) identify the amount of mainstem river salmon spawning and juvenile rearing habitat lost to development and operations of the Columbia River hydroelectric system, 2) identify the types of ecological modifications that have occurred, and 3) suggest areas or actions with particular potential for restoration of riverine habitat. The first chapter of this report is a quantitative assessment of salmon and steelhead habitats lost because of hydroelectric development. Chapter Two provides results of a workshop with a list of restoration options, including risks and benefits of implementing those options, for mainstem habitats in the Columbia and Snake rivers. Chapter three of this report provides a test of two restoration strategies: 1) drawdown of John Day reservoir on the lower Columbia River, and 2) removal of the four lower Snake River dams. The final chapter includes conclusions, constraints to analysis, and recommendations for related research. Collectively, the results of our studies represent significant progress toward defining locations in the Columbia and Snake rivers with greatest potential for restoration of mainstem riverine processes and salmon habitats. Most data products are presented in a Geographic Information System (GIS) format to facilitate information exchange among fisheries scientists and resource managers.

\section{CHAPTER ONE-EFFECTS OF HYDROELECTRIC DEVELOPMENT ON MAINSTEM RIVERINE PROCESSES AND SALMON HABITS}

Salmon habitats in the Columbia and Snake rivers have changed dramatically during the past 60 years because of hydroelectric development and operation. For example, much of the former riverine environment where salmon spawned is now a series of low-velocity impoundments. Hydroelectric dams have also created impassable barriers that block access of salmon and steelhead to many historic habitats. Changes in water quality, temperature, food supply, and flow regimes have also affected salmon survival and behavior. The overall effect of these changes to freshwater aquatic ecosystems has been a reduction in the production capacity of the Columbia River for anadromous salmonids.

Specific objectives of this study were to assess the extent of riverine habitat lost as a result of development and operation of the hydroelectric systems. The focus of our analysis was fall chinook salmon (Oncorhynchus tshawytscha) because these populations carry out their entire freshwater life cycle within mainstem habitats of the Columbia and Snake rivers. Only limited data was available on both historical and current mainstem spawning areas for steelhead. We defined three development periods in the Columbia River Basin to help assess changes due to physical habitat modifications: pre-hydro development, or prior to construction of any mainstem dams (pre-1910), hydro development (1910 to 1984), and post-hydro development. Changes in systems operations, structural operations, and increases in upstream storage capacity occurred during each of these periods. Our initial effort focused on defining the importance of landscape processes to salmonid habitat, with the next level of analysis occurring at the channel scale or river segment. Geomorphic features were assessed by incorporating historic and contemporary spatial data into a GIS. The geographical extent of spatial data range from Bonneville Dam to Kettle Falls on the Columbia River $(\sim 900 \mathrm{~km})$ and the Snake River from its mouth to Shoshone Falls, Idaho $(\sim 1000 \mathrm{~km})$. Both qualitative descriptions and quantitative data on spawning areas were compiled for all three development periods and incorporated into the GIS through the use of dynamic segmentation. 
Geomorphology characteristics used for analysis included thalweg elevation and geologic features within $1 \mathrm{~km}$ of the mainstem. Historic and current channel planform features were compiled from maps, georeferenced, edgematched, and joined into contiguous GIS data layers. A geomorphic spawning habitat model was then developed based on geologic composition of the river bank, longitudinal gradient, and presence/absence of channel bars.

The first level of analysis included quantifying lost riverine habitat in terms of lineal distance of freeflowing river. This iteration provided an upper bounds to the estimate of lost production area. Only about 13 and 58\% of the historic mainstem Columbia and Snake rivers, respectively, are still considered riverine. The biggest loss of riverine habitat in the Columbia River occurred downstream of the Snake River confluence where only $\sim 3 \%$ of historic riverine habitat still exists, mostly in the tailraces downstream of hydroelectric projects. Nearly $70 \%$ of historic mainstem riverine habitat remains in the upper Snake River. However, this habitat is upstream of Hells Canyon Dam and not accessible to anadromous salmonids.

The next level of analysis involved quantifying lost spawning habitat. We determined that $\sim 661$ and $805 \mathrm{~km}$ of the Columbia and Snake rivers, respectively, were once used by fall chinook salmon for spawning. Fall chinook salmon currently use only $\sim 85 \mathrm{~km}$ of the mainstem Columbia River and $163 \mathrm{~km}$ of the mainstem Snake River for spawning. The total amount of historic habitat (i.e., actual use based on redd densities) is unknown because of the lack of precision associated with surveys of historic spawning areas.

When we applied our geomorphic spawning model to the entire Columbia River Basin, we predicted approximately 283 and $311 \mathrm{~km}$ of spawning habitat was available to fall chinook salmon in the mainstem Columbia and Snake rivers during the pre-hydro development period. This distance is $\sim 40-50 \%$ less than that documented as historic spawning habitats. When the model was applied to specific river reaches containing the highest known redd densities, we predicted that only 20 to $66 \%$ of the total habitat available for spawning would be suitable for spawning. About $97 \%$ of habitat identified as suitable for fall chinook salmon in the Snake River system was upstream of present migration barriers (i.e., Hells Canyon Dam) to anadromous fish.

Flow regulation has altered the natural hydrograph is the Columbia River Basin, particularly during the latter half of the $20^{\text {th }}$ century. Both flood control and hydropower loading practices have resulted in a dampening of the seasonal maximum and minimum discharge regions. Construction and operation of low-head reservoirs on the mainstem Columbia and Snake rivers has not produced a significant change in the average temperature of the two rivers. However, large upstream storage projects have resulted in a delay in the transport of water through the reservoir system, resulting in a temperature phase shift.

Construction of mainstem dams has fragmented historic populations of fall chinook salmon and reduced the flow of colonists between local populations. The two remaining populations of fall chinook salmon have responded differently to this isolation. Fall chinook salmon have successfully exploited suitable spawning and rearing habitat in the Hanford Reach as other production areas became inundated by mainstem reservoirs; in contrast, Snake River populations are listed as endangered under the Endangered Species Act. 
Our analysis substantiated the assertion that historic spawning areas for fall chinook salmon occurred primarily within wide alluvial floodplains once common in the mainstem Columbia and Snake rivers. These areas tended to possess more unconsolidated sediment, more bars and islands, and had lower slopes than areas not extensively used. We identified three river reaches downstream of present migration barriers with high potential for restoration of riverine processes: the Columbia River upstream of John Day Dam, the Columbia-Snake-Yakima River confluence, and the lower Snake River upstream of Little Goose Dam. Because flows in the mainstem are highly regulated, the pre-development alluvial river ecosystem is not expected to be restored simply by operational modification of one or more dams. Establishing more normative flow regimes, specifically sustained peak flows for scouring, would be essential to restoring the functional characteristics of existing, altered habitats. Restoring populations to any of these reaches also requires that population genetics and viability of potential seed populations (i.e., from tributaries and tailrace spawning areas, and hatcheries) be considered.

\section{CHAPTER TWO-OPTIONS FOR RESTORATION OF MAINSTEM HABITATS}

The Battelle/USGS team held a one-day workshop in August 1999 to develop a list of mainstem restoration options. A select group of participants was invited based on their involvement with regional assessments of hydrosystem operations and knowledge of mainstem aquatic habitats. The intent was to focus on scientific issues related to restoration of riverine processes; resource management policy and socioeconomics were not major considerations. The workshop process was facilitated and included brainstorming of restoration options, development of criteria for ranking options, discussion of options, and final prioritization.

Six general categories of restoration options were initially developed at the workshop: 1) reservoir drawdown, 2) flow management practices, 3) dam removal, 4) engineered fixes, 5) anadromous fish passage, and 6) other. The risks and benefits of specific options (e.g., remove Little Goose dam) under each general category were summarized for two categories of salmonids 1) juvenile and adult anadromous salmonids within existing aquatic ecosystems, and 2) resident salmonids present in reservoir systems upstream of current barriers to anadromous fish migration.

After identifying the risks and benefits associated with various mainstem habitat restoration options, participants were asked to consider what criteria could be used to determine whether an implemented action actually resulted in restoration of riverine habitat. The primary purpose of having criteria was to give participants a defined basis for reviewing and ranking the relative value or benefit of each restoration option. A list of attributes of an alluvial river system, compiled from several sources, was presented for discussion. The list of attributes included characteristics such as spatially complex channel morphology and natural variability in flows and water quality. A description of each attribute and its ecological significance was also presented.

Following extensive discussion on whether participant choices were truly based on the agreed-upon selection criteria, each person voted on the initial list of 30 specific options for restoring mainstem habitats. The dam breaching and flow management categories were most favored by participants (32\% of votes cast), followed by reservoir drawdown (18\%) and engineered fixes (7\%). The top three options selected for restoring mainstem habitats were to 1) conduct a phased drawdown of McNary Reservoir, 
2) restore an annual hydrograph, and 3) breach the four lower Snake River dams. A major uncertainty associated with the selected options was whether we could adequately define the geologic environment that salmon prefer for spawning and/or rearing. In addition, any "restored" habitat would likely require flow management changes to be viable. Concerns were also expressed regarding potential impacts of drawdown and dam removal on the current transportation program for juvenile salmonids.

A key assumption to implementing possible actions (or combinations of actions) to restore normative riverine processes, is that the habitat upon which salmon and steelhead evolved will be restored and that populations will respond positively. Participants in the workshop initially focused on single options for restoring mainstem habitats. However, most felt that one or more hydroelectric project would need to be breached or that more than one reservoir would have to be drawn down to produce a positive effect. These actions would have to be implemented in combination with providing a more normative hydrograph (via manipulation of upstream storage reservoirs). Both the geomorphologic and hydrologic aspects of the Columbia and Snake rivers will ultimately "control" the time required for restoration of riverine processes. Socioeconomic and political aspects of the proposed actions were not factored into our discussions, but will likely drive the decisions that result in implementation of any restoration option.

\section{CHAPTER THREE-TESTS OF TWO RESTORATION OPTIONS}

The Battelle/UGSG study team conducted a detailed analysis of two options for restoring mainstem habitats and riverine processes. The options were selected based on both the workshop results and availability of information on physical habitat characteristics of the river reaches evaluated. The first restoration option, drawdown of John Day reservoir, was ranked number four by workshop participants. The USGS team had the lead for this analysis, building upon previous work conducted by Sheer (1999). The second option, natural river drawdown of lower Snake River dams, was selected as the third highest priority option by workshop participants. The Battelle team used the extensive data base summarized in Hanrahan et al (1998) as the basis for their analysis.

Drawdown of John Day reservoir-The objective of this analysis was to evaluate whether physical habitat for spawning and rearing of fall chinook salmon could be restored in the John Day reservoir. Our analysis included characterizing the physical features of the reservoir under three operational scenarios: 1) normal pool levels, 2) spillway crest drawdown, and 3) full drawdown or natural river channel. These features were then modeled under varying hydraulic conditions to determine the potential spatial distribution and extent of fall chinook salmon spawning and rearing areas.

Habitat patches suitable for spawning are distributed throughout the reservoir under natural river conditions. These patches were concentrated upstream of rkm 410 for spillway crest water level and limited to the extreme upper end of the reservoir (i.e., upstream of rkm 455 for normal operating pool level). Based on water depth and velocity criteria alone, up to 53, 22, and $3 \%$ of the total reservoir area would be potential suitable spawning habitat for fall chinook salmon under natural river, spillway crest, and normal pool conditions, respectively. It is important to note that these estimates are liberal due to data limitations. Additionally, the areas of potential habitat suggest where spawning might occur if reservoir drawdown were implemented, rather than where spawning would occur. 
Comparison of the three water level scenarios showed that restoration to natural river conditions would result in more potential rearing habitat for fall chinook salmon than would either maintaining normal operations or drawing down a reservoir to spillway crest. The greatest increases in rearing habitat would occur in the lower, more confined portion of John Day reservoir. The large-scale resolution of available geographic data (10- x 10-m cells) could not accurately predict fine-scale microhabitat variations in depth and velocity. This limitation may have biased our estimates of potential rearing habitat upward. However, the values are useful for comparing operational and restoration strategies for fall chinook salmon in John Day reservoir.

In summary, our analysis showed that changes in river morphology resulting from a reservoir drawdown to natural river water surface elevations provided significant increases in potential suitable spawning habitat for fall chinook salmon and slight increases in rearing habitat. Other necessary hydrologic features, including frequency of flood events and seasonal variation in river discharge are also important in creating and maintaining the abiotic and biotic conditions required for fall chinook salmon to successfully carry out their life history.

Removal of Four Lower Snake River Dams-To address this option, our analysis had three objectives: 1) describe the physical characteristics and habitats of the pre-dam river, 2) quantify the geomorphic features that describe fall chinook salmon production areas, and 3) evaluate changes in the flow regime under natural river drawdown. The 266-km study area was classified into geomorphic units based on an evaluation of the watershed-scale controlling factors of channel morphology (i.e., geology, physiography, and channel planform). Characterization at the reach scale was based on analysis of hydraulic geometry and channel morphology at cross-sections spaced 0.4 to $0.8 \mathrm{~km}$ apart. Channel substrate data were incorporated from general data on grain size and spatial distribution. All quantitative data sets for known fall chinook salmon spawning locations and associated redd densities were incorporated into the GIS through the use of dynamic segmentation. A geomorphic spawning habitat model was then created based on the relationship between redd densities and geomorphic features.

Based on a coarse-scale analysis of geomorphic characteristics, the majority of the study area ( $74 \%)$ was classified as alluvial or partially alluvial. Two reaches that may be important restoration areas are from the Snake-Columbia confluence upstream to rkm 31 and near the confluence of the Clearwater River. On a dam-by-dam basis, the section of the Snake River between Little Goose Dam and Lower Granite Dam and the section upriver of Lower Granite Dam contained the largest number and highest percentage of partially alluvial reaches.

We estimated that $\sim 131 \mathrm{~km}$ or $55 \%$ of the lower Snake River may have been available as suitable spawning habitat during the pre-hydroelectric development period based on our geomorphic model. In contrast, historic accounts suggest that only $51 \mathrm{~km}$ of the lower Snake River was used for spawning by fall chinook salmon. The geomorphic model suggests that approximately $87 \%$ of the lineal river distance between Little Goose and Lower Granite dams contains geomorphic characteristics conducive to fall chinook salmon spawning or the largest proportion on a dam-by-dam basis. These results are different than a model that used suitable depth, substrate, and velocity (USFWS 1999) to predict that the section from Lower Monumental to Little Goose dams had the most potential spawning habitat under natural river drawdown. 
Analysis of historic and contemporary discharge records indicates that regulated flow regimes under natural river drawdown will be competent enough to result in channelbed mobilization. The time required before the channel characteristics and riverine processes are realized depends on many factors, including an initial 5-to 10-year period of erosion and transport of accumulated fine sediments. The frequency and duration of maximum discharge events $\geq 2707 \mathrm{~m}^{3} / \mathrm{sec}$ would determine the eventual time required for initiation of such processes. It is important to note that many other factors, yet to be addressed or resolved, govern the recovery of lower Snake River physical habitats and processes that fall chinook salmon require for spawning and rearing.

\section{EPILOGUE}

In conclusion, we believe the primary actions required for recovery of anadromous salmonids dependent on mainstem habitats are re-establishment of natural flow regimes and maintenance of geomorphic features common to alluvial floodplains. Changes to these essential riverine processes because of extensive hydroelectric development have contributed to significant population declines in fall chinook salmon. Consequently, it is not possible to increase natural production of fall chinook salmon in the Columbia River Basin without restoring those controlling factors and processes that supported their life history requirements. In this context, selective reservoir drawdown and/or dam breaching, in combination with establishment of more normative flow regimes, is the only viable strategy for restoring mainstem habitats. Restoration goals must also recognize that other ecosystem changes and environmental pressures have reduced the production potential of mainstem habitats from that provided by the historic template. 


\section{ACKNOWLEDGMENTS}

This report could not have been possible without the cooperation and hard work of researchers from several organizations. Individual contributors for the data analysis and reporting aspects of the project were as follows: Dennis Dauble, David Geist, and Tim Hanrahan (Battelle); Michael Parsley, Mindi Sheer, Kenneth Tiffan, Rodney Garland, and Dennis Rondorf (U.S. Geological Survey/Biological Resources Division). We thank Ernie Brannon (University of Idaho), Christopher Frissel (University of Montana), Rick Williams (Clear Creek Genetics), Chip McConnaha (Northwest Power Planning Council), and Dan Daley and Bill Maslen (Bonneville Power Administration) for their review and comment on various drafts. We also thank Alan Ruger (Bonneville Power Administration) for his technical oversight. Georganne O'Connor (Battelle) was our technical editor. 


\section{CONTENTS}

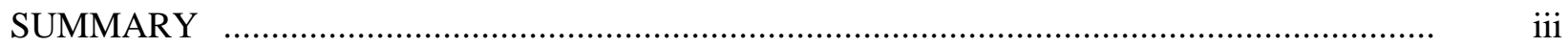

ACKNOWLEDGMENTS ......................................................................................... ix

\section{CHAPTER ONE-EFFECTS OF HYDROELECTRIC DEVELOPMENT ON MAINSTEM RIVERINE PROCESSES AND SALMON HABITATS}

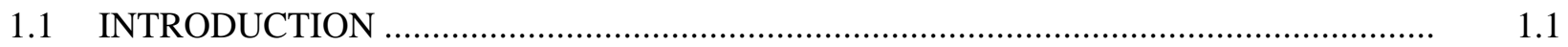

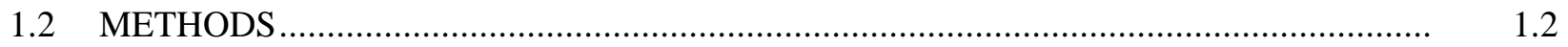

1.2.1 FISHERIES DATA ............................................................................ 1.3

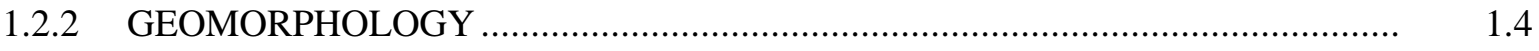

1.2.3 CHANNEL PLANFORM ........................................................................... 1.4

1.2.4 GEOMORPHIC FEATURES AT SPAWNING LOCATIONS................................. 1.6

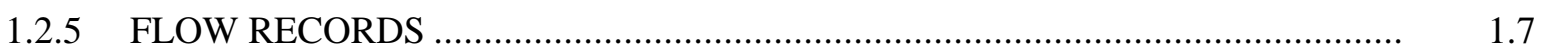

1.3 ENVIROMENTAL SETTING ……........................................................................

1.3.1 POPULATION STATUS OF FALL CHINOOK SALMON …………………….... 1.8

1.3.2 WATERSHED CHARACTERISTICS ............................................................ 1.11

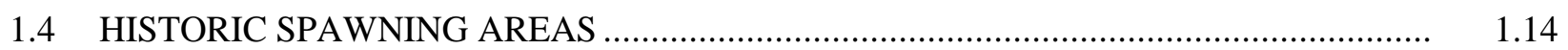

1.4.1 FALL CHINOOK SALMON.................................................................. 1.14

1.4.2 STEELHEAD .................................................................................... 1.19

1.4.3 OTHER ANADROMOUS SALMONIDS ......................................................... 1.21

1.5 CURRENT SPAWNING AREAS ……………….................................................... 1.21

1.5.1 FALL CHINOOK SALMON ...................................................................... 1.21

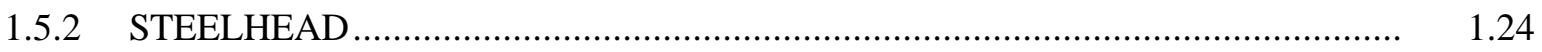

1.5.3 OTHER ANADROMOUS SALMONIDS....................................................... 1.26

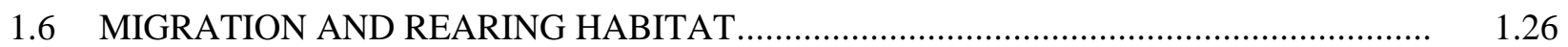

1.7 CHANGES IN HABITAT AVAILABILITY FOR FALL CHINOOK SALMON .................. 1.27

1.7.1 SPATIAL ANALYSIS HIERARCHY ............................................................. 1.27

1.7.2 ASSESSMENT OF LOST HABITAT ……………………………………... 1.28

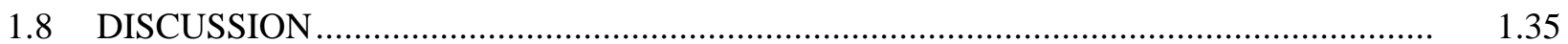

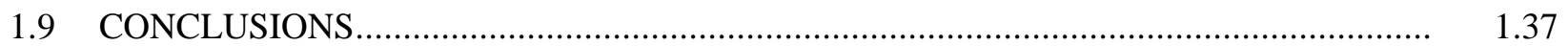

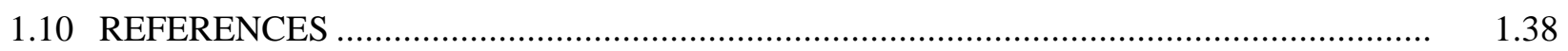

\section{CHAPTER TWO-OPTIONS FOR RESTORATION OF MAINSTEM HABITATS}

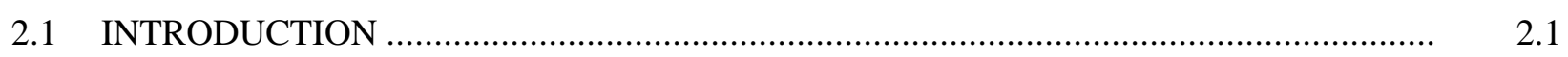

2.2 IDENTIFICATION OF RESTORATION OPTIONS ………………………………........ 2.1

2.3 EVALUTION CRITERIA ....................................................................................... 2.6

2.4 PRIORITIZAITON OF MAIN OPTIONS ………………………………….............. 2.10

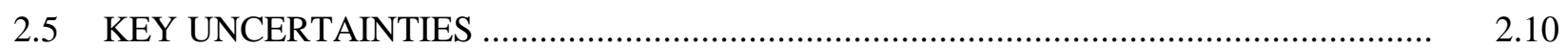

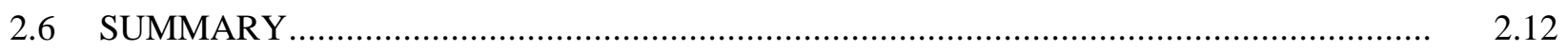




\section{CHAPTER THREE-TESTS OF TWO RESTORATION STRATEGIES}

DRAWDOWN OF JOHN DAY RESERVOIR

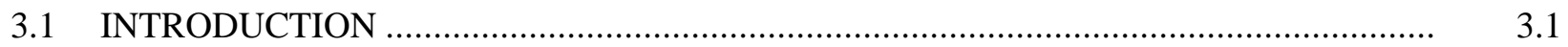

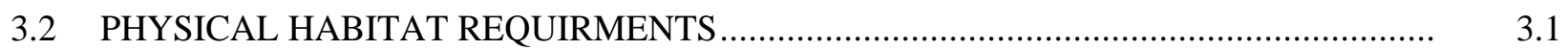

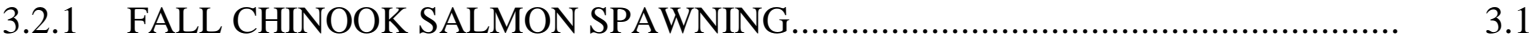

3.2.2 FALL CHINOOK SALMON REARING ........................................................ 3.2

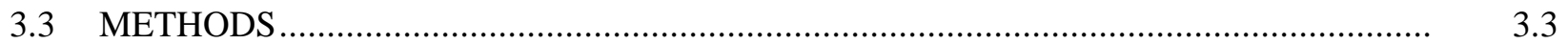

3.3.1 FALL CHINOOK SPAWNING HABITAT MODEL ....................................... 3.3

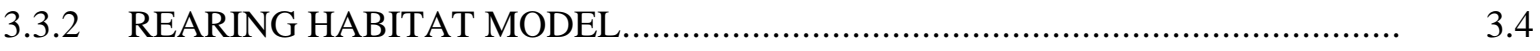

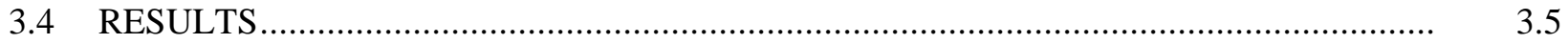

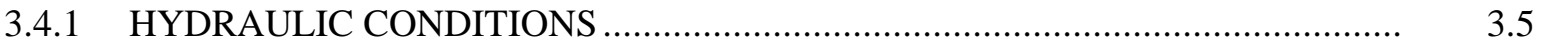

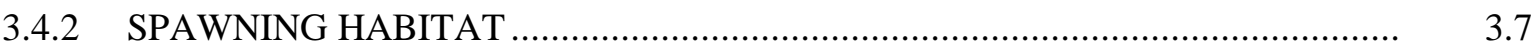

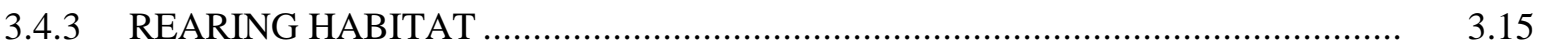

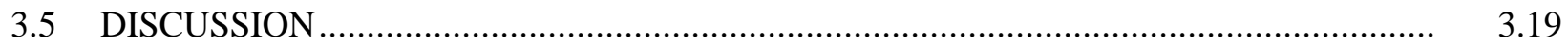

REMOVAL OF FOUR LOWER SNAKE RIVER DAMS

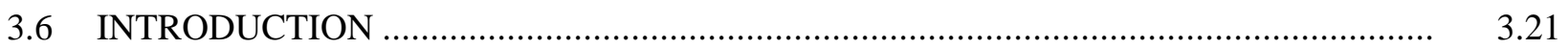

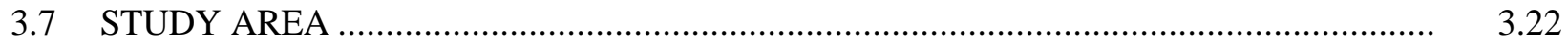

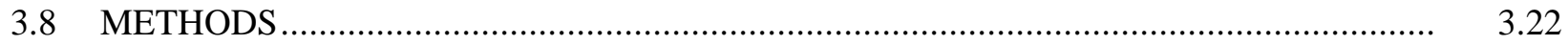

3.8.1 COARSE-SCALE GEOMORPHIC CHARACTERIZATION ............................... 3.22

3.8.2 REACH-SCALE CLASSIFICATION............................................................ 3.24

3.8.3 ADDITIONAL HYDRAULIC AND GEOMORPHIC CHARACERISTICS........... 3.26

3.8.4 GEOMORPHIC FEATURES AND SALMON PRODUCTION AREAS ............... 3.27

3.8.5 FLOW REGIME AND SEDIMENT TRANSPORT ............................................. 3.28

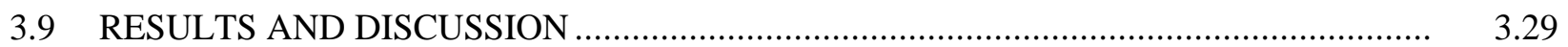

3.9.1 COARSE-SCALE GEOMORPHIC CHARACTERIZATION ................................ 3.29

3.9.2 REACH-SCALE CLASSIFICATION ................................................................... 3.33

3.9.3 ADDITIONAL HYDRAULIC AND GEOMORPHIC CHARACTERISTICS ........ 3.33

3.9.4 GEOMORPHIC FEATURES AND SALMON PRODUCTION AREAS ............... 3.46

3.9.5 FLOW REGIME AND SEDIMENT TRANSPORT ............................................. 3.49

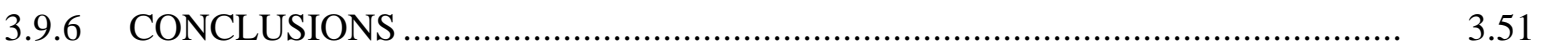

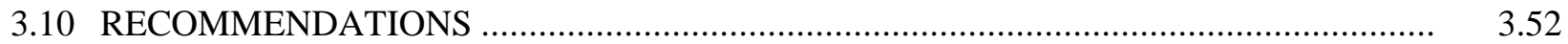

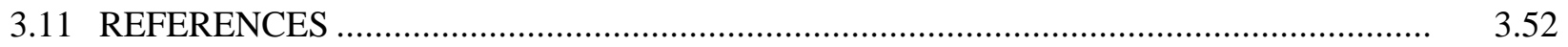

EPILOGUE

APPENDIX A - SUMMARY OF FALL CHINOOK SALMON SPAWNING IN MAINSTEM COLUMBIA AND SNAKE RIVERS......................................... A. A

APPENDIX B - NAMES AND ADDRESSES OF WORKSHOP PARTICIPANTS.................... B. B

APPENDIX C - SYNOPSIS OF RESTORATION OPTIONS AS PRESENTED BY INDIVIDUAL PARTICIPANTS …............................................................. C.1 


\section{FIGURES}

1.1 Principal Geologic Features for a Section of the Columbia River.

1.2 Lower Snake River Planform Channel Morphology Under Present Reservoir Conditions and Pre-Dam Riverine Conditions

1.3 Mainstem Dam Passage Counts and Escapement to Major Production Areas for Fall Chinook Salmon

1.4 Principal Geological Features of the Columbia and Snake Rivers.

1.5 Water Surface Elevation for the Columbia and Snake Rivers ....

1.6 Lower Columbia River, The Dalles, Flow Data from 1878 to 1998 Showing Average Daily, Monthly Maximum and Minimum, and Amplitude.

1.10 Post-Hydro Development Period Fall Chinook Spawning Locations

1.11 Fall Chinook Hatcheries and Tributary Spawning Locations

1.12 Comparison of Geomorphic Features in Spawning Sites Documented During the Preand Hydro Development Period and With Greater than 100 redds $/ \mathrm{km}$

1.13 Geomorphic Spawning Habitat Model and Pre-Hydro Development Period Fall Chinook Spawning Locations.....

1.14 Application of the Geomorphic Model to Spawning Sites Documented During the Preand Hydro Development Period with Greater than 10 redds/km

3.1 Spatial Extent of Wetted Surface Area of the Columbia River Between John Day and McNary Dams for Normal Operating Pool, Spillway Crest, and Natural River Scenarios for a Discharge of $300 \mathrm{kcfs}$

3.2 Longitudinal Profile of Water Surface Elevation for John Day Reservoir, With a River Discharge of $100 \mathrm{kcfs}$. 
3.3 Longitudinal Profile of Water Surface Elevation for John Day Reservoir, With a River Discharge of $156 \mathrm{kcfs}$.

3.4 Longitudinal Profile of Water Surface Elevation for John Day Reservoir, With a River Discharge of $300 \mathrm{kcfs}$.

3.5 Distribution of Water Velocity Under Different Water Level Scenarios Based on Hydraulic Model Results

3.6 Percent of Pool, Run, and Riffle Habitat Derived From Water Depth and Velocity....

3.7 Distribution of Pools, Runs, and Riffles for Normal Operating Pool River Level Derived from Froude Number.

3.8 Distribution of Pools, Runs, and Riffles for Spillway Crest River Level Derived from Froude Number.

3.9 Distribution of Pools, Runs, and Riffles for Natural River Level Derived from Froude Number

3.10 Percent of Suitable Fall Chinook Salmon Spawning Habitat Derived from Water Depth and Velocity.

3.11 Distribution of Suitable and Unsuitable Fall Chinook Spawning Habitat Based on Water Depth and Velocity for Three Operational Scenarios

3.12 Acres of Rearing Habitat with High Probability or Low Probability for Habitat Cells Containing 10 or More Subyearling Fall Chinook Salmon at Normal Operating Pool, Spillway Crest, and Natural River Operational Scenarios in John Day Reservoir...

3.13 Example of Shoreline Fall Chinook Salmon Rearing Habitat Probabilities for John Day Reservoir at a Discharge of $4417 \mathrm{~m}^{3} \mathrm{~s}^{-1}$

3.14 Acres of High Probability and Low Probability Subyearling Chinook Salmon Rearing Habitat by 16-km Sections in John Day Reservoir at Simulated Flows of $4417 \mathrm{~m}^{3} \mathrm{~s}^{-1}$ for Normal Operating Pool, Spillway Crest, and Natural River Operational Scenarios.

3.16a Level 1 Classification for Lower Snake River

3.16b Level 1 Classification for Lower Snake River. 


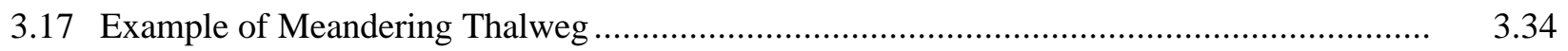

3.18 Example of Meandering Filament of Maximum Velocity ............................................ 3.34

3.19 Level 2 Classifications as a Percent of Lower Snake River ......................................... 3.36

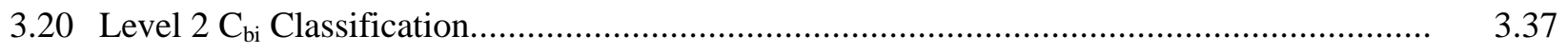

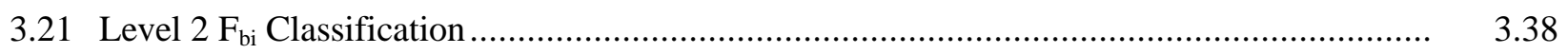

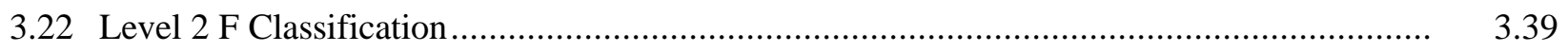

3.23 Mean Velocity and Mean Depth at Each Cross Section for $\mathrm{Q}_{50}$ Flow.............................. 3.41

3.24 Stream Power at Each Cross Section for $\mathrm{Q}_{50}$ Flow .................................................... 3.42

3.25 Longitudinal Profile of Water Surface and Thalweg Elevations for $\mathrm{Q}_{50}$ Flow .................... 3.43

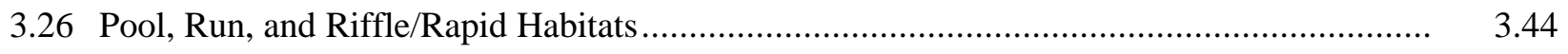

3.27 Channel Shape Indices at Each Cross Section for $\mathrm{Q}_{50}$ Flow .......................................... 3.45

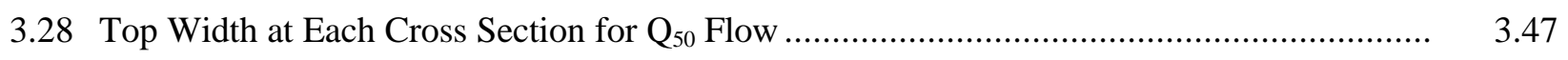

3.29 Geomorphic Spawning Habitat Model and Pre-Hydro Development Period Fall Chinook

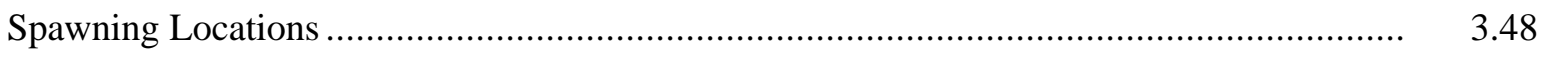

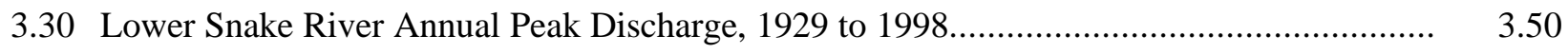

3.31 Estimated Time to Remove Fine Sediments from Lower Granite Reservoir Under Natural

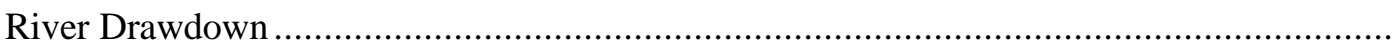




\section{TABLES}

1.1 Hydroelectric Dam Timeline for the Columbia and Snake Rivers and

Operating Characteristics.

1.2 Summary of Discharge Characteristics for Long-Term Monitoring Stations in the Columbia and Snake Rivers.

1.3 Summary of Major Historic Spawning Areas for Fall Chinook Salmon in the Mainstem Columbia and Snake Rivers

1.4 Summary of Known Spawning Areas for Fall Chinook Salmon in the Mainstem Columbia and Snake Rivers, Post-Hydroelectric Development Period.

1.5 Fall Chinook Salmon Hatcheries Upstream of Columbia River km 231.

1.6 The Lineal Distance of Potential Spawning Habitat that Existed Before Hydroelectric Development of the Mainstem Snake and Columbia Rivers Compared to the Amount Currently Available

1.7 Summary of Surface Area, Shoreline Length, and Channel Complexity for the Mainstem Columbia and Snake Rivers Prior to Hydroelectric Development and Under Current Conditions.

2.1 Initial List of Options for Restoring Mainstem Habitats of the Columbia and Snake Rivers

2.2 Risks and Benefits of Different Restoration Options to Juvenile and Adult Anadromous Salmonids in Existing Aquatic Ecosystems and to Resident Salmonids Present in Reservoir Systems Upstream of Current Barriers to Anadromous Fish Migration.

2.3 Attributes of an Alluvial River System

2.4 Top Six Mainstem Habitat Restoration Options Selected by Workshop Participants and a Summary of Associated Uncertainties

3.1 Area and Percentages for Habitat Cells Containing 10 or More Subyearling Chinook Salmon Rearing Habitat for Normal Operating Pool, Spillway Crest, and Natural River Operational Scenarios at Flows Simulated at $2832 \mathrm{~m}^{3} \mathrm{~s}^{-1}, 4417 \mathrm{~m}^{3} \mathrm{~s}^{-1}$, and $8495 \mathrm{~m}^{3} \mathrm{~s}^{-1}$ in John Day Reservoir

3.2 Grain Size Classification

3.3 Level 2 Characteristics 
3.4 Example and Description of Level 2 Classification ................................................ 3.26

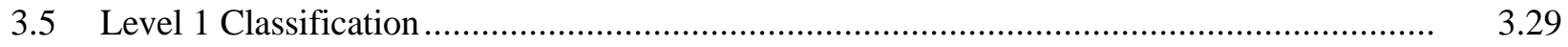

3.6 Level 2 Classification Descriptions by Level 1 Class .............................................. 3.35

3.7 Level 2 Classifications as Percent of Lower Snake River .............................................. 3.36

3.8 Level 2 Classifications as Percent of Lower Snake River Segments ................................ 3.40

3.9 Pool, Riffle/Rapid, Run Habitats of Lower Snake River Segments ...................................

3.10 Geomorphic Spawning Habitat Model Prediction for Lower Snake River Sections ............. $\quad 3.49$

3.11 Fall Chinook Spawning Habitat Under Natural River Conditions Based on Modeled

Depths, Velocities, and Substrates ....................................................................... 3.49

3.12 Lower Snake River Change in Annual Maximum Discharge for Pre- and Post-Major Storage Periods; Units are $\mathrm{m}^{3} \mathrm{~s}^{-1}$ 


\section{CHAPTER ONE \\ EFFECTS OF HYDROELECTRIC DEVELOPMENT ON MAINSTEM RIVERINE PROCESSES AND SALMON HABITATS}

\subsection{INTRODUCTION}

Columbia River Basin anadromous fish runs at the turn of the $20^{\text {th }}$ century were estimated to range from 10 to 16 million fish (NPPC 1986). In contrast, the estimated current average annual run-size is about 2.5 million fish. There are many reasons for the decline in fish runs, including over-fishing in the mid-1800s (Van Hyning 1973; Smith 1979) and habitat degradation following European development from the late 1800s to present-day (NPPC 1986). Although the exact amount of fish lost to hydropower development is uncertain, the fact remains that salmon habitats in the Columbia and Snake rivers have changed dramatically during the past 60 years because of hydroelectric development and operation. For example, much of the former riverine environment where salmon spawned is now a series of low-velocity impoundments. Several hydroelectric dams have created impassable barriers that block access of salmon and steelhead to many historic habitats. Changes in water quality (e.g., dissolved gas), temperature, food supply, and flow regimes have also affected salmon survival and behavior during their freshwater residence period (Ebel et al. 1989). The overall effect of these changes to the aquatic ecosystem has been a reduction in the natural production capacity of the Columbia River system for anadromous salmonids (Raymond 1988; Ebel et al. 1989; Rondorf et al. 1990; Berggren and Filardo 1993; Dauble and Watson 1997; and others).

There is now considerable debate regarding management activities directed specifically toward recovering these lost mainstem production areas. Restoration of mainstem habitats through dam removal and/or reservoir drawdown is a possible component of recovery planning for salmon and steelhead species currently protected under the Endangered Species Act (ESA) (USACE 1992, 1994). However, some stakeholders have argued that the ecological risks and benefits of these proposed actions have not been adequately studied. To date, no systematic assessment of the extent and types of habitat modifications resulting from dam construction has been made. Additionally, potential locations for restoration of riverine processes and/or specific benefits to salmon and steelhead have not been identified.

Of the seven species of Pacific salmon (Oncorhynchus spp.) that were historically found in the Columbia River Basin, fall chinook salmon were most affected by the development of the mainstem Columbia and Snake rivers. This is because most fall chinook salmon populations carry out their entire freshwater life cycle within the mainstem habitats of the Columbia and Snake rivers. Thus, they are the most vulnerable to physical habitat modifications resulting from construction and operation of mainstem hydroelectric dams and have been the primary focus of our investigations. Because steelhead and spring chinook salmon also used mainstem habitat for spawning/rearing (steelhead) and migration (both species), we also included them in our analysis of historical habitats. However, with one exception (Fulton 1970), little evidence exists on which to base an estimate of spawning habitat lost in the mainstem for steelhead, and only general information exists for assessing lost migration habitat for both species. Therefore, these species do not form a significant part of findings in this report. 
This study, initiated in October 1998, addresses uncertainties associated with the loss of salmon and steelhead production areas in the mainstem Columbia and Snake rivers. Specific objectives were to assess the extent of riverine habitat lost as a result of development and operation of the Columbia River Basin hydroelectric system and to identify the types of modifications that have occurred to remaining lotic habitats. We identify both historic and current production areas for fall chinook salmon and discuss how their population status was influenced by hydroelectric development. The relationship between geomorphic characteristics of the Columbia River Basin and spawning/rearing habitats of mainstem populations of salmon and steelhead is also presented.

\subsection{METHODS}

To help assess changes that are a result of physical habitat modifications, we defined three development periods in the Columbia River Basin:

1. Pre-hydro development. This period occurred before construction of any major mainstem dams (pre1910). During this period, all mainstem habitats within the limits of anadromous fish production were not yet impacted by construction or operation of hydroelectric dams. Impacted means that upstream passage of adult salmon and steelhead was blocked by a dam, and that water surface elevations and velocities were altered by normal water storage and power peaking operations.

2. Hydro development. The second period covers the extended time frame when dams were being constructed in the basin (1910-1984).

3. Post-hydro development. This period has involved changes in systems operations, structural modifications, and increases of upstream storage capacity.

Because of the large spatial scale of this study, our initial effort was a coarse-level assessment. That is, we first focused on quantifying the importance of landscape processes relative to salmonid habitat, with the next level for assessment at the channel scale or river segment (e.g., 1-10 river widths in length). Our experience in the Hanford Reach of the Columbia River and the Hells Canyon Reach of the Snake River suggested that the following landscape-level features are highly important to salmon production: hydrograph magnitude, timing, and duration; longitudinal slope of the water surface; and geomorphic features that promote groundwater-surface water interaction (e.g., geologic composition, channel bars). Geomorphic features were assessed by incorporating historic and contemporary spatial data into a Geographic Information System (GIS).

The geographical extent of historic and contemporary spatial data used range from Bonneville Dam to Kettle Falls on the Columbia River ( $\sim 900 \mathrm{~km}$ total distance), and on the Snake River from its mouth to Shoshone Falls, ID (rkm 990). All GIS data layers were georeferenced to the same projection and coordinate system. Each of the data sources had varying degrees of resolution and accuracy. For example, the highest spatial resolution was available from the 1934 U.S. Army Corps of Engineers (USACE) hydrographic survey maps (1:2,000 scale), while the 1:100,000 scale U.S. Geological Survey (USGS) Digital 
Line Graphs (DLGs) represented the lowest resolution. Along with differences in scale and resolution of the source maps, the ability to accurately register maps during digitizing varied among data sources and introduced additional error in georeferencing.

\subsubsection{FISHERIES DATA}

Our approach was to compile all quantitative data sets collected prior to and during the hydro development period and use these data as the basis for comparison to the post-hydro development period. Descriptions of spawning areas before the early $20^{\text {th }}$ century were limited to brief, mostly qualitative descriptions of migrating or spawning adults by trappers, early naturalists, and Native American tribes. No basin-wide surveys of spawning were ever conducted. Indeed, no comprehensive survey of any general spawning area for fall chinook salmon was conducted prior to the 1940s. Fulton (1970) summarized known distribution of fall chinook salmon and steelhead before completion of several mainstem dams. However, he did not differentiate between spawning/rearing areas and those areas used strictly as migration corridors. Only the Hanford Reach of the Columbia River (1947 to present) and portions of the upper Snake River (1959 to 1976; 1986 to present) have long-term monitoring records for fall chinook salmon spawning.

The main purpose of early spawning surveys was to provide baseline information on the distribution and numbers of salmon redds present before construction of planned hydroelectric projects. These data sets, acquired during the hydro development period, provide the best quantitative measure of habitat used. Whether these same habitats were used by salmon to the same extent before Europeans settled in the Pacific Northwest is unknown.

Changes in population size of adult salmon returning to the Columbia River Basin were based primarily on dam passage counts, available only after the hydroelectric development period. The distribution and relative abundance of adult salmon returning to mainstem habitats before dam construction was not well documented. Overall, population size of returning adults during the latter part of the $19^{\text {th }}$ century could be inferred from commercial catch statistics (see Chapman 1986). However, catch records did not always separate out the three different runs of chinook salmon for the pre-hydroelectric period (i.e., from $\sim 1870$ to 1910 ).

All quantitative data sets for fall chinook spawning locations and redd densities, representing all hydro development periods (pre, current, post) were incorporated into the GIS by dynamic segmentation. These data sets were built as linear event tables containing locational information (e.g., from rkm to rkm), attribute data, and data base keys linking to the reference source for the attribute data. The event tables were then linked to their location in the mainstem Columbia and Snake rivers through the use of 1:100,000 scale Pacific Northwest River Reach Files (PNW RRF) obtained from the USGS and StreamNet. These files include GIS data layers containing line segments that represent the channel midline. 


\subsubsection{GEOMORPHOLOGY}

Riverbed elevations in the thalweg were available for the section of the Columbia River from downstream of Bonneville Dam to Priest Rapids Dam and from a section of the Snake River from the mouth to rkm 383. A running average of thalweg elevations for 5 river miles $(8 \mathrm{~km})$ was taken for every half mile $(0.8 \mathrm{~km})$ and $25 \mathrm{ft}(8 \mathrm{~m})$ was added to each of these elevation measurements to obtain approximate water surface elevations. English units were converted to metric units for analysis. For the remaining sections of the rivers, the river midlines and all river kilometers and points at which elevation contours cross the river midlines were digitized from USGS 7.5-minute quadrangles into the GIS. Using dynamic segmentation, the river midlines were then calibrated using the elevation contour points. Elevations were calculated for every $0.8 \mathrm{~km}$ along these sections of the rivers using the calibrated midlines. Two possible sources of error in the estimates were that some sections, of the river were discordant with adjacent sections and river miles were missing from some quadrangles.

Data for geologic features of Washington, Oregon, and Idaho were incorporated into the GIS. The data originated at a scale of 1:500,000 and contained descriptions of geologic formation, rock type, age, and major lithology (Johnson and Raines 1996; Raines and Johnson 1996). The data layers for each individual state were edgematched and joined into one GIS coverage for the entire study area. Only geologic features within $1 \mathrm{~km}$ of the mainstem Columbia and Snake rivers were retained in the coverage for further analyses (Figure 1.1). The geologic units of these river valleys were subsequently classified into two classes based on geological formations (unconsolidated sediments and bedrock), and compared with hard copy maps of geologic features in the study area.

\subsubsection{CHANNEL PLANFORM}

Historic channel planform features (e.g., shoreline, bars, islands, near-shore topography) were incorporated into the GIS from a variety of sources, depending on geographic location. The USGS Columbia River Research Laboratory processed the spatial data for the Columbia River from Bonneville Dam to the mouth of the Snake River (rkm 230-518). Information for Bonneville through Celilo Falls (rkm 230-323) was taken from 1931 USGS quad sheets (1:24,000) and 1936 U.S. Army Corps of Engineers land survey maps. The maps used for Celilo Falls through Crow Butte (rkm 323-416) were 1931 War Department hydrographic survey maps at a scale of 1:10,000. Maps used for Crow Butte through the mouth of the Snake River (rkm 416-518) were 1:2,000 and 1:4,000 scale 1935 War Department maps. Aerial photographs from $1944(1: 20,000)$ were also scanned and georeferenced to help delineate substrate areas from Crow Butte to McNary Dam (rkm 416-467). The discharge at which these shorelines were mapped is unknown.

Historic spatial information for the Columbia River from the confluence of the Snake River upriver to the international border was taken from 1930 USGS maps (1:31,680 scale). Pre-dam planform features for the Snake River from its mouth upriver to the Washington/Oregon border were acquired from 1934 U.S. Army Corps of Engineers maps (1:2,000 scale). All maps were georeferenced, digitized, and edgematched during processing. Spatial information acquired from the resulting GIS coverages included shoreline extent (right bank, left bank, islands), near-shore topography, and water surface elevation. 


\section{Geology Area 7}

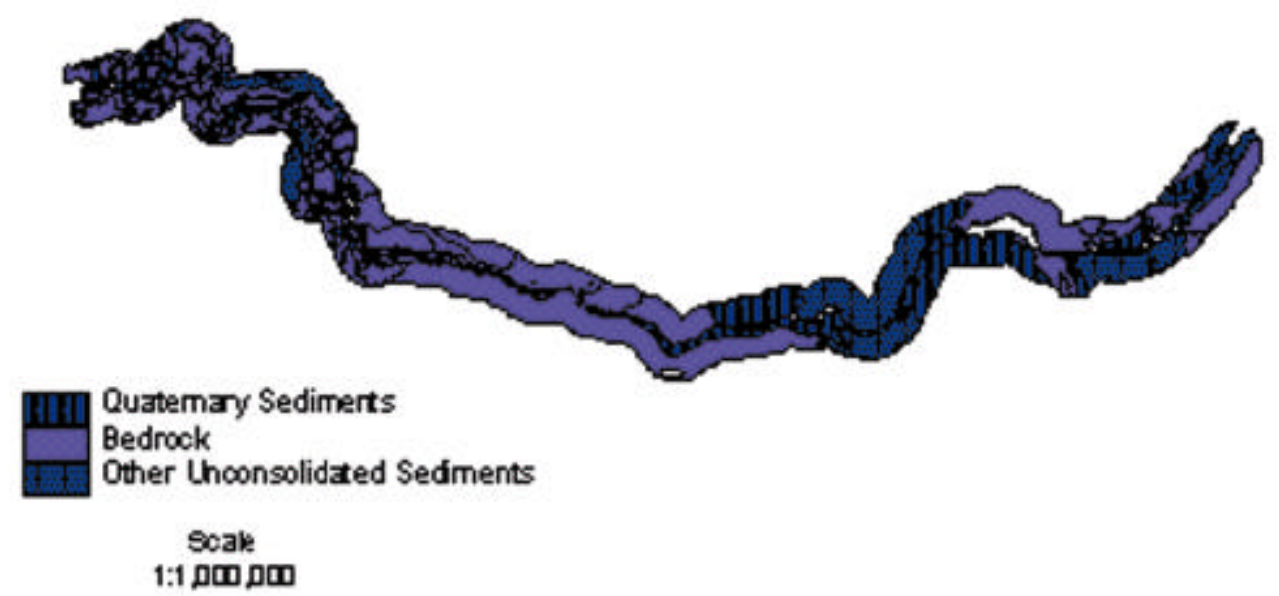

Figure 1.1. Principal Geologic Features for a Section of the Columbia River

The availability of historic information for the remainder of the Snake River was limited to any predam spatial data existing in the present-day 1:24,000 scale USGS digital line graph (DLG) files. In some sections (e.g., from Brownlee Dam upriver to Swan Falls Dam) pre-dam planform channel characteristics (e.g., shoreline, islands) were contained in the DLG files. In other sections of the river such pre-dam characteristics were not present in the DLG files. However, because of the location of some Snake River dams, planform characteristics in some sections of the river have not changed appreciably since hydropower development (e.g., Hells Canyon Reach of the Snake River). Spatial information acquired from the resulting GIS coverages included shoreline extent (right bank, left bank, islands), near-shore topography, and water surface elevation. The discharge at which these shorelines were mapped is unknown.

Channel planform characteristics for present-day conditions were taken from 1:24,000 and 1:100,000 scale USGS DLG files for the entire study area. The 1:100,000 scale DLGs were used where the 1:24,000 scale DLGs were unavailable from the USGS. The discharge at which these shorelines were mapped is unknown. Near-shore topography for the entire mainstem Columbia and Snake rivers was acquired from 7.5', 1:24,000 scale USGS digital elevation models (DEMs) with cell resolutions of $30 \mathrm{~m}$. All individual DLGs and DEMs were georeferenced, edgematched, and joined into contiguous GIS data layers. An example of channel planform for the lower Snake River during historic and present-day conditions is shown in Figure 1.2. 


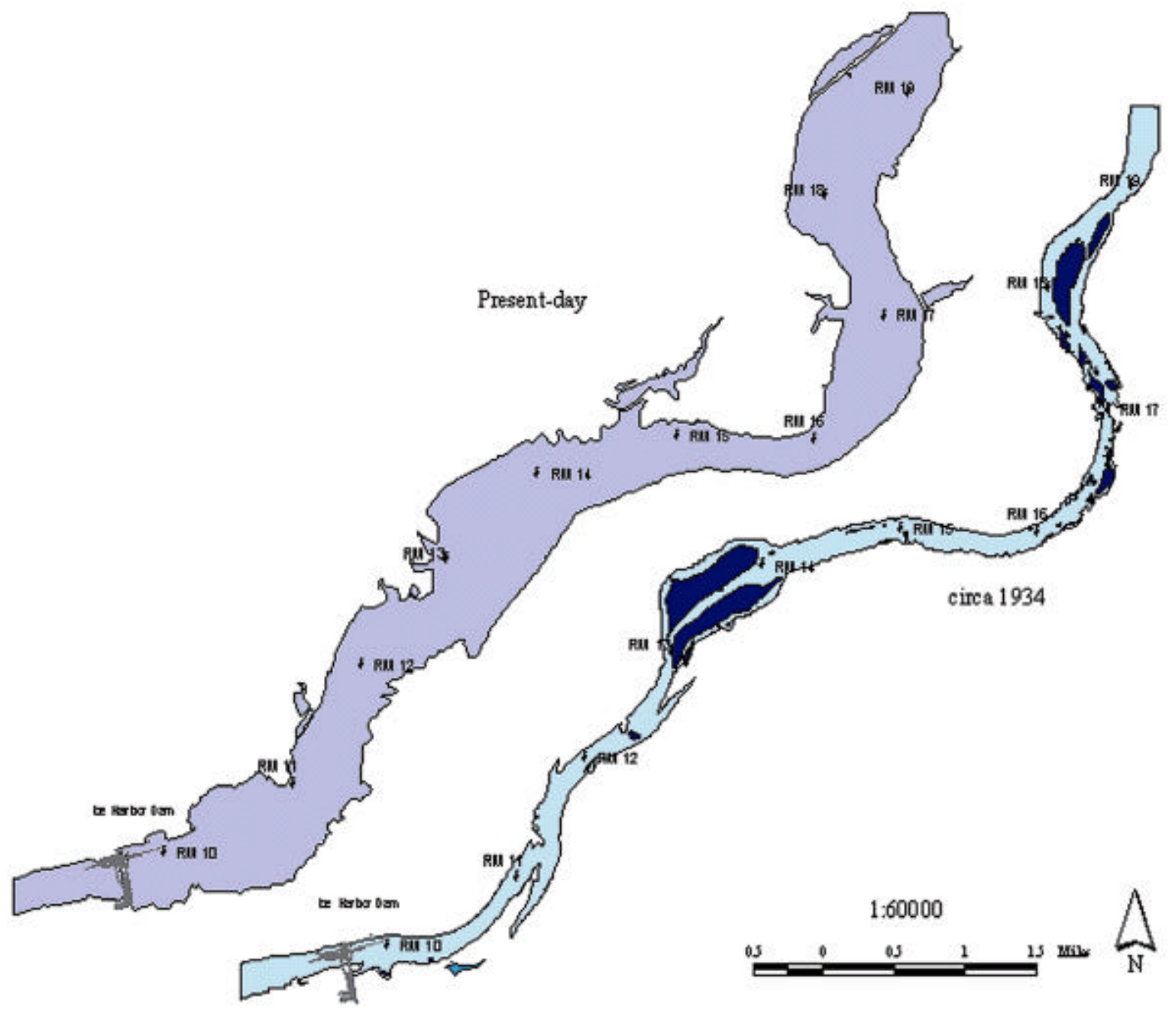

Figure 1.2. Lower Snake River Planform Channel Morphology Under Present Reservoir Conditions (Lake Sacajawea) and Pre-Dam Riverine Conditions

\subsubsection{GEOMORPHIC FEATURES AT SPAWNING LOCATIONS}

Geomorphic characteristics were assessed by incorporating historic and contemporary spatial data into the GIS. We used the geology and planform data layers to quantify the geologic composition and availability of depositional features along the mainstem Columbia and Snake rivers. The 1:100,000 scale PNW RRF were segmented into 500-m linear sections and used as the base layer for delineating geologic and depositional features. As such, the delineation of these features correlate spatially with the delineation of fall chinook salmon spawning locations described earlier.

To differentiate geologic features important to salmon production, the geologic composition of the right and left bank (facing downriver) for each 500-m segment was estimated through the use of nearest 
neighbor analysis in the GIS. Each 500-m segment was assigned the geologic attributes (geologic formation, rock type, age, major lithology, and bedrock/unconsolidated classification) of the nearest right bank and left bank geologic unit. A composite geologic typing of each 500-m segment was calculated by averaging the right and left bank bedrock/unconsolidated classification. Thus, each $500 \mathrm{~m}$ segment could be classified into one of three types: $100 \%$ unconsolidated, 50/50 unconsolidated/bedrock, or 100\% bedrock. The same composite geologic typing was completed for longer contiguous river sections as well (e.g., 32-km spawning section), resulting in different percentages of geologic composition for these sections as a whole.

Planform depositional features (bars and islands) were interpreted from planform GIS data layers. The data layers used included those depicting right- and left-bank shorelines, cutoff channels, islands, and near-shore topography (contour lines and hillshaded DEMs). Depositional features were incorporated into the analysis by delineating each 500-m segment into one of three classes: islands or bars present, islands or bars absent, or unknown. Only genetic features - those constructed by the present-day river through the course of lateral shifting or flooding (Kellerhals et al. 1976; Kellerhals and Church 1989)_were included in the classification. The term "genetic features" is used to differentiate them from terraces deposited during cataclysmic events (e.g., the Bonneville Flood) that were constructed at elevations exceeding present-day peak flood stages. Genetic features were interpreted based on their elevation relative to the water surface elevation and near-shore topography. Segments were classified as unknown if pre-dam channel planform data was absent, and if bars could not be interpreted from the planform characteristics as a result of the absence of near-shore topography data. An example of segments classified as unknown is in the upper Snake River (e.g., C.J. Strike Reservoir), where the absence of predam near-shore topography and planform features limit the ability to accurately interpret depositional characteristics. A composite depositional typing for contiguous river sections (e.g., 32-km spawning section) was calculated by determining the proportion of a given contiguous section classified as depositional features present, absent, and unknown.

Redd density data for fall chinook salmon spawning in the Columbia and Snake rivers was used to evaluate the relationship between various geomorphic features and spawning areas. Our geomorphic spawning habitat model was based on the following three features: 1) geologic composition of the river bank, 2) longitudinal gradient of water surface, and 3) presence, absence of channel bars or islands. These features have previously been shown to be important for describing fall chinook salmon spawning areas (Dauble and Geist, in press). Segments of river were considered usable for spawning if they contained greater than 50\% unconsolidated sediment, contained bars and/or islands, and were less than 0.0005 units in longitudinal gradient. River segments that failed to meet all criteria were considered unsuitable spawning habitat.

\subsubsection{FLOW RECORDS}

Continuous discharge records were obtained from USGS records for two Columbia River locations: The Dalles (rkm 305) for 1878-1998 and Vernita (rkm 637) for 1918-1994. Snake River discharge records are for the mainstem downstream of the Clearwater River at Clarkston (rkm 260). Data from the gauging station at Clarkston was used for 1928-1974, and discharge from 1974-1994 was estimated from combined discharge records at Anatone (rkm 270) and the Clearwater River. 


\subsection{ENVIRONMENTAL SETTING}

Effects of hydro development on salmon populations are not easy to differentiate from the effects of other human activities (i.e., harvest, hatchery production, pollution, etc.) because dams were constructed over a relatively long time span and distance. In 1910, Swan Falls Dam (rkm 735) blocked anadromous fish access to former production areas in the upper Snake River. Construction of Rock Island Dam at rkm 730 in 1933 initiated the period of hydroelectric development in the Columbia River. Grand Coulee Dam, constructed at rkm 960 in 1941, was the first high-head dam to completely block anadromous fish migration in the Columbia River. Eight more hydroelectric projects were constructed in the Columbia River from 1953 to 1968. The period of major hydroelectric development for the Snake River occurred slightly later, from 1958 to 1975. The post-hydro electric development period has involved changes in systems operations, structural modifications, as well as increases of upstream storage capacity. For example, three large hydroelectric projects were constructed in Canada from 1968 to 1984. The addition of these projects more than doubled the water storage capacity of the Columbia River system.

Construction and operation of mainstem dams resulted in blocked access to historic production areas, changed downstream spawning and rearing areas from flowing habitats to a series of slackwater pools, and modified seasonal patterns of flow and temperature. These changes occurred very early in the $20^{\text {th }}$ century (Table 1.1). Five of the first hydroelectric projects in the Snake River were built upstream of the range of anadromous fish populations. However, in 1910 Swan Falls Dam eliminated nearly 25\% of the mainstem lotic habitat that was available to Snake River salmon and steelhead at that time. The first hydroelectric dams built in the Columbia River (i.e., Rock Island Dam at rkm 730 and Bonneville Dam at rkm 235 in 1933 and 1938, respectively) had fish ladders that allowed upstream passage of adult salmon and steelhead. In contrast, Grand Coulee Dam (rkm 960) blocked access of Columbia River anadromous salmonids to $\sim 17 \%$ of their upstream production areas when it was constructed in 1941. A total of 15 hydroelectric dams were constructed in the Snake and Columbia rivers from 1953 to 1975. Collectively, these projects converted almost 1,000 km of riverine habitat to reservoir habitat. The Hells Canyon Dam complex, built from 1958 to 1967 , effectively blocked access of salmon and steelhead to $338 \mathrm{~km}$ of mainstem riverine environment. Additionally, reservoirs behind mainstem hydroelectric dams reduced the average water velocity for impounded reaches, reduced habitat diversity, and increased water surface elevations. All of these modifications resulted in extensive changes to aquatic ecosystems and riverine processes that salmon and steelhead had adapted to and responded to since they first colonized the Columbia River Basin.

\subsubsection{POPULATION STATUS OF FALL CHINOOK SALMON}

The current run size for fall chinook salmon can be fairly accurately measured based on fish counts at dams and from harvest statistics (WDFW/ODFW 1996). In contrast, historical run sizes can only be estimated based on early catch statistics and/or habitat availability (Chapman 1986). Pre-development accounts indicate that large numbers of adult fall chinook salmon returned to the floodplains adjacent to and downstream of the Snake River-Columbia River confluence in southeastern Washington and to the Snake River upstream of Hells Canyon in southwestern Idaho (Gilbert and Evermann 1894; DeVoto 1953). In his report to the vice-president of the United States dated May 31, 1894, Mr. Marshall McDonald, U.S. Commissioner of Fish and Fisheries, testified that "There is no reason to doubt-indeed, 
Table 1.1. Hydroelectric Dam Timeline for the Columbia and Snake Rivers and Operating Characteristics

\begin{tabular}{|c|c|c|c|c|}
\hline River/Project & Date & River km & $\begin{array}{c}\text { Reservoir Length } \\
(\mathbf{k m})\end{array}$ & $\begin{array}{c}\text { Storage Capacity } \\
\text { (acre ft) }\end{array}$ \\
\hline \multicolumn{5}{|l|}{ Snake River } \\
\hline Idaho Falls - Lower & 1904 & 1278 & Run of River & 800 \\
\hline Milner & 1905 & 1028 & & 14,200 \\
\hline Minidoka & 1906 & 1086 & 26 & 220,000 \\
\hline Shoshone Falls & 1907 & 988 & & 12,500 \\
\hline Jackson Lake & 1907 & 1591 & 16 & 847,000 \\
\hline Swan Falls & 1910 & 735 & & 6,900 \\
\hline Idaho Falls & 1913 & 1281 & ROR & 400 \\
\hline American Falls & 1927 & 1149 & 22 & $1,671,300$ \\
\hline Twin Falls & 1935 & 933 & & 10,000 \\
\hline Idaho Falls - Upper & 1937 & 1288 & ROR & 800 \\
\hline Upper Salmon Falls B & 1947 & 933 & & 1,200 \\
\hline Lower Salmon Falls & 1949 & 922 & & 18,500 \\
\hline Bliss & 1950 & 901 & & 11,000 \\
\hline C.J. Strike & 1952 & 795 & & 250,000 \\
\hline Palisades & 1957 & 1451 & 16 & $1,401,600$ \\
\hline Brownlee Dam & 1958 & 459 & 60 & $1,420,060$ \\
\hline Oxbow Dam & 1961 & 439 & 12 & 58,200 \\
\hline Ice Harbor Dam & 1962 & 16 & 31.9 & 407,000 \\
\hline Hells Canyon Dam & 1967 & 397 & 26 & 167,720 \\
\hline L. Monumental Dam & 1969 & 67 & 28.7 & 377,000 \\
\hline Little Goose Dam & 1970 & 113 & 37.2 & 565,200 \\
\hline Lower Granite Dam & 1975 & 173 & 43.9 & 483,800 \\
\hline \multicolumn{5}{|l|}{ Columbia River } \\
\hline Rock Island Dam & 1933 & 730 & 20 & 135,000 \\
\hline Bonneville Dam & 1938 & 235 & 45 & 600,000 \\
\hline Grande Coulee Dam & 1941 & 960 & 151 & $9,562,000$ \\
\hline McNary Dam & 1953 & 470 & 61.6 & $1,350,000$ \\
\hline Chief Joseph Dam & 1955 & 879 & 50.9 & 480,000 \\
\hline The Dalles Dam & 1957 & 308 & 24 & 330,000 \\
\hline Priest Rapids Dam & 1959 & 639 & 30 & 250,000 \\
\hline Rocky Reach Dam & 1961 & 762 & 42 & 430,000 \\
\hline Wanapum Dam & 1963 & 669 & 60 & 748,000 \\
\hline Wells Dam & 1967 & 830 & 28 & 361,200 \\
\hline John Day Dam & 1968 & 347 & 76.4 & $2,530,000$ \\
\hline Keenleyside Dam & 1968 & 1633 & 145 & $8,337,000$ \\
\hline Mica Dam & 1973 & 1263 & 134 & $20,000,000$ \\
\hline Revelstoke Dam & 1984 & & 80 & $4,300,000$ \\
\hline
\end{tabular}


the fact is beyond question-that the number of salmon now reaching the head waters of streams in the Columbia River basin is insignificant in comparison with the number which some years ago annually visited and spawned in these waters" (p. 5, Gilbert and Evermann 1894). The initial declines in salmon and steelhead populations that occurred during the late $19^{\text {th }}$ and early $20^{\text {th }}$ centuries were mainly attributed to high rates of commercial harvest (Van Hyning 1973; Smith 1979). Chapman (1986) concluded that summer and late spring chinook salmon made up most of the commercial harvest for 1881-1885 or the peak catch period for chinook salmon according to Van Hyning (1973). This observation is consistent with Thompson's (1951) determination that summer chinook salmon were the main component of the adult run in the 1870s. Peak catches of fall chinook salmon were thought to occur from 1915 to 1919 or after the summer run was severely overfished (Chapman 1986). Consequently, the reference period for assessing how hydroelectric development influenced populations of fall chinook salmon returning to the Snake River is earlier than that for populations returning to mainstem habitats in the Columbia River.

Numbers of fall chinook salmon (adult and jacks) migrating to upriver spawning areas in the Columbia River Basin have varied widely since 1938 (Figure 1.3). For example, peak numbers of fall chinook salmon over Bonneville Dam reached 416,000 in 1986 with lowest numbers occurring from 1953-1962 (10-year average: 136,000). From 8 to 59\% of all adults migrating over Bonneville Dam passed McNary Dam from 1954 to 1994. Adult passage counts at McNary Dam reflect only the upriver bright component destined for spawning areas in the Snake River, Hanford Reach, and areas upstream of Priest Rapids Dam. Escapement of fall chinook salmon to the Hanford Reach increased after the

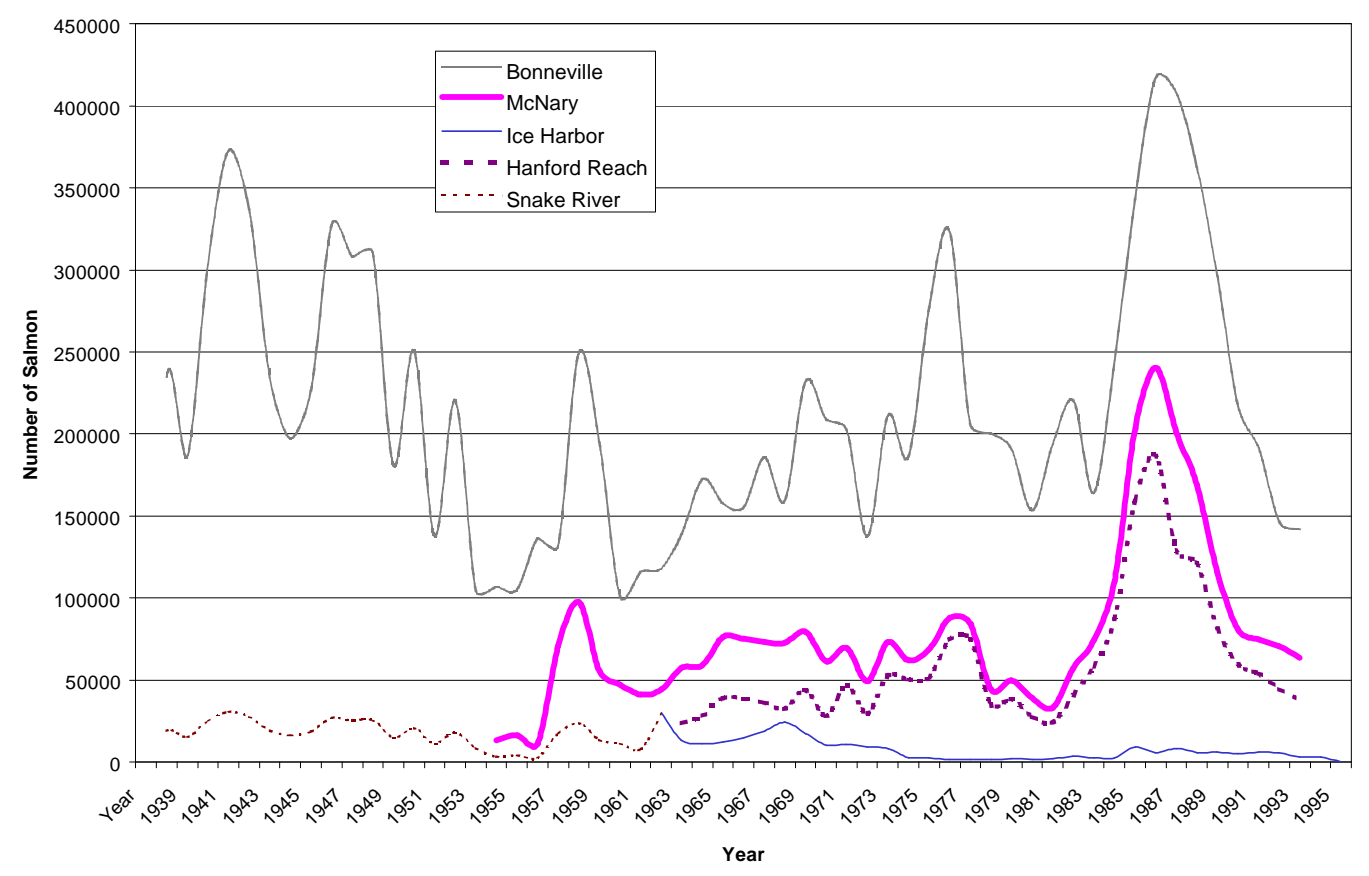

Figure 1.3. Mainstem Dam Passage Counts and Escapement to Major Production Areas for Fall Chinook Salmon. Snake River values are based on Irving and Bjornn (1981). All other values are from WDFW (WDFW 1996). 
mid-1950s or following the completion of three mainstem dams near the Snake River-Columbia River confluence. Peak escapement of about 200,000 adults to the Hanford Reach occurred in the mid- to late 1980s, and escapement has averaged >50,000 adults since 1994 (WDFW/ODFW 1996; Dauble and Watson 1997).

In contrast, both numbers and relative proportion returning to the Snake River have declined drastically over the last 40 years. For example, annual escapement of fall chinook salmon to the Hells Canyon Reach of the Snake River has averaged <1,000 adults from 1987 to 1995 or only about $1 \%$ of the total passage over McNary Dam. The estimated number of fall chinook salmon returning to the Snake River declined dramatically after completion of the Hells Canyon Dam complex. For example, numbers of adult fall chinook salmon passing Brownlee-Oxbow dams declined from $29 \%$ to $2 \%$ of the McNary Dam counts from 1957 to 1963 . Haas (1965) attributed the decline in returning adults to hydroproject operations, since the 1962 run was the first run to have all year classes exposed to the full influence of the Brownlee-Oxbow projects. The most obvious population decline (i.e., from 30,000 to 13,500 adults over Ice Harbor Dam, rkm 16) occurred between 1962 and 1963, or after passage of fall chinook salmon upstream of Oxbow Dam (rkm 460) was stopped. A second major population decline (i.e., from an estimated 8,300 to 2,800 adults) occurred between 1973 and 1974, following construction of Little Goose Dam (rkm 113).

\subsubsection{WATERSHED CHARACTERISTICS}

The Columbia River watershed extends from the mountains of eastern British Columbia, Canada to southern Idaho/Oregon and drains an area of approximately $668,000 \mathrm{~km}^{2}$ (van der Leen et al. 1990). The Snake River is its largest tributary (entering at rkm 522) and flows from it source near the Grand Tetons in Wyoming, across southern Idaho, and along the Washington-Oregon border for a distance of 1,700 km. It covers a watershed area of approximately $280,000 \mathrm{~km}^{2}$ (van der Leen et al. 1990).

\subsubsection{Geology}

The surface topography in the Columbia River Basin has been modified by several geomorphic processes, including Pleistocene cataclysmic flooding, Holocene eolian activity, and landsliding. Major geological features of the Columbia and Snake rivers, within the limits of former fall chinook salmon production, can be generally separated into Quaternary (i.e., alluvial), other unconsolidated sediments, and bedrock. Quaternary sediments were deposited in four major areas: lower Columbia River downstream of the present Bonneville Dam site, near the Snake-Columbia river confluence, upstream of Hells Canyon, and in the Marsing area upstream of the Boise River (Figure 1.4). Much of the remaining stream channel is confined by bedrock, with small deposits of Quaternary and other unconsolidated sediments present.

\subsubsection{Longitudinal Slope}

In general, and within the range of historic fall chinook salmon spawning areas, the longitudinal slope of the Columbia River is not as steep as the Snake River (Figure 1.5). However, the longitudinal slope of 


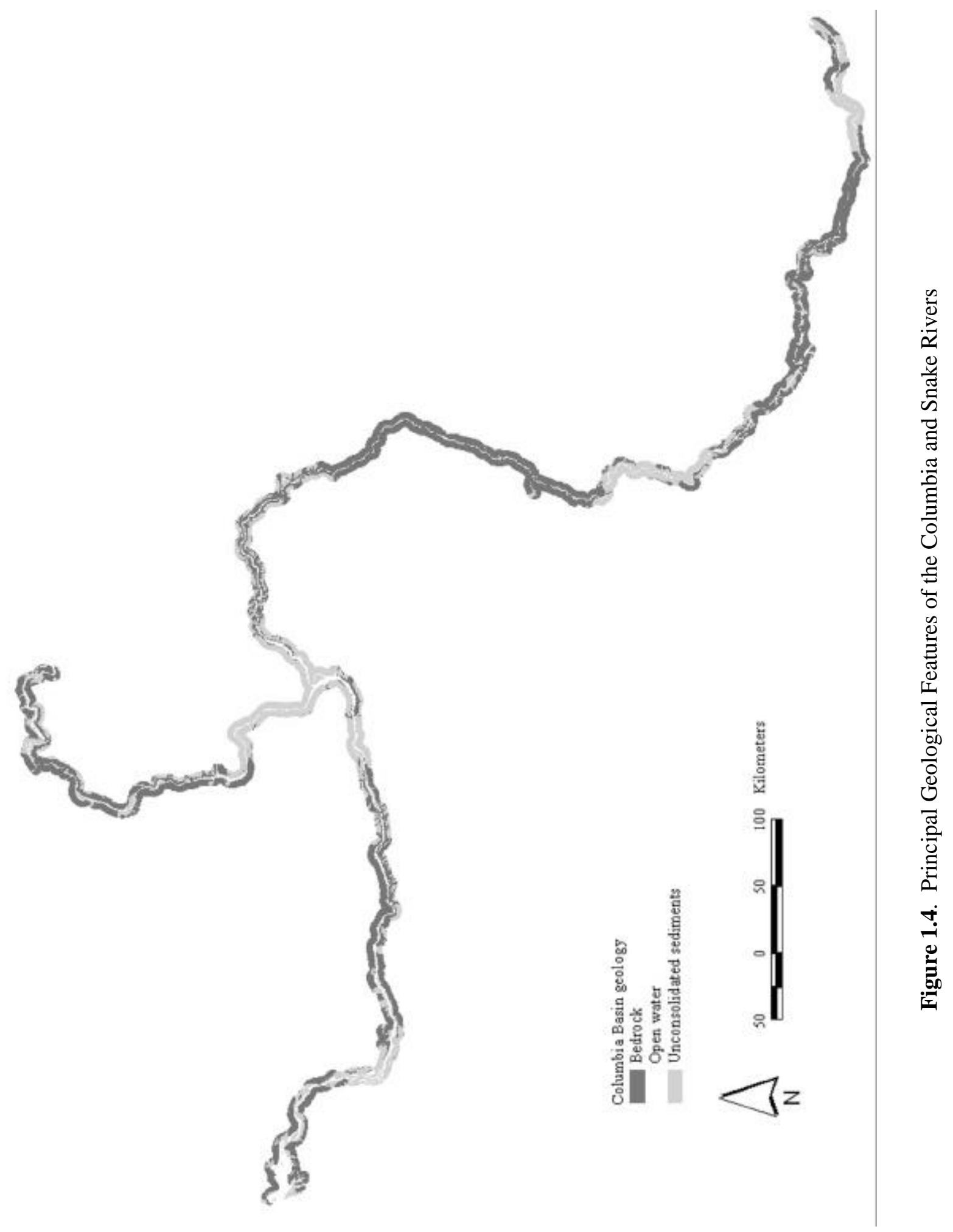

1.12 


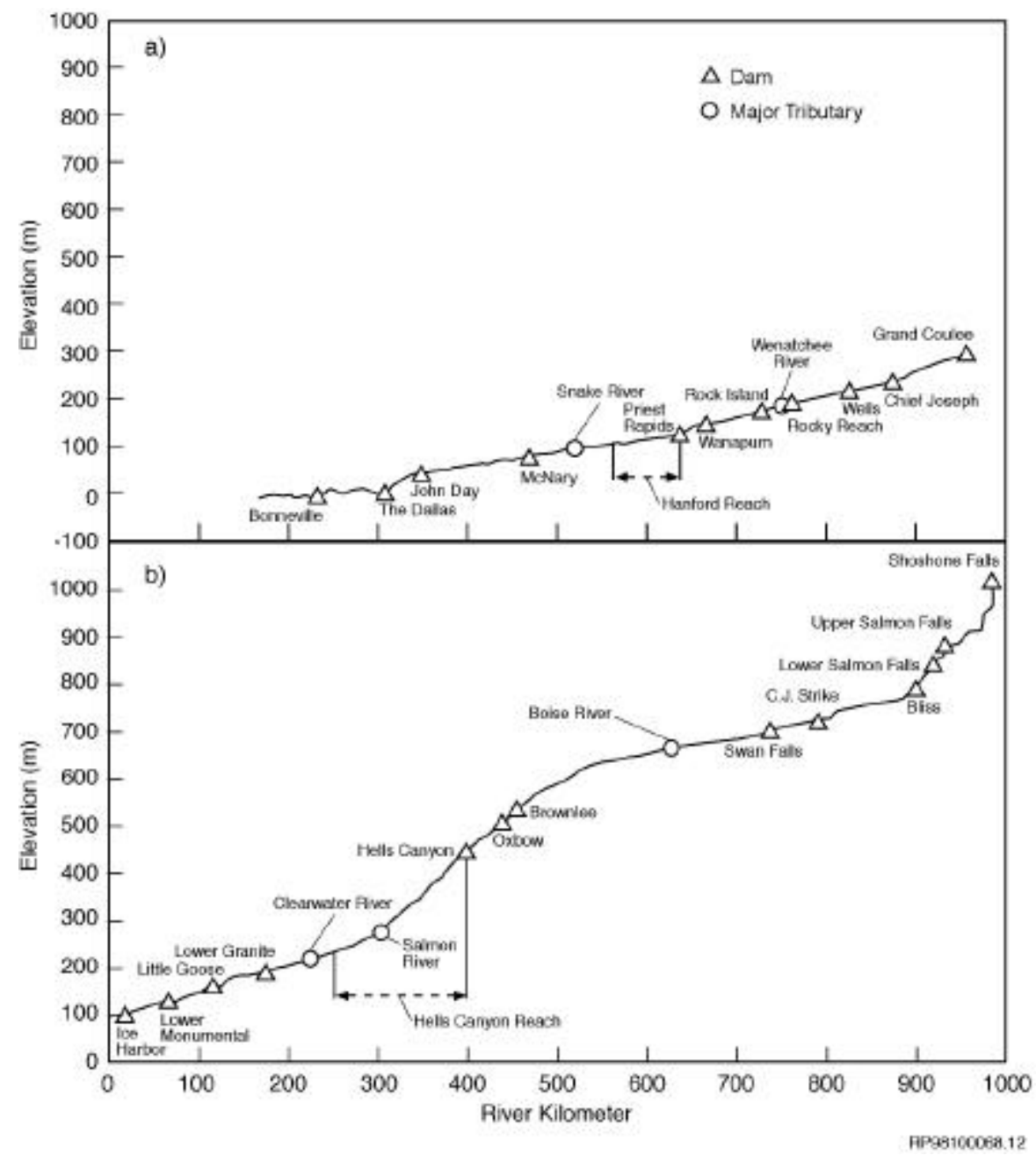

Figure 1.5. Water Surface Elevation for the Columbia and Snake Rivers

both river systems varies according to location within the larger watershed. For example, the Columbia River has a relatively uniform slope of about $0.25 \mathrm{~m} / \mathrm{km}$ from its confluence with the Deschutes River, Oregon, to Priest Rapids Dam; the slope then increases to about $0.45 \mathrm{~m} / \mathrm{km}$ from Priest Rapids Dam to Chief Joseph Dam (Figure 1.5a). Before dam construction, there were a succession of rapids and one waterfall in the mid-Columbia River between Wenatchee and Pasco, Washington. The greatest drop in elevation was at Priest Rapids, where the river fell $22 \mathrm{~m}$ in about $18 \mathrm{~km}(1.2 \mathrm{~m} / \mathrm{km}$; U.S. Army 1952).

There are four major changes in slope within the Snake River system (Figure 1.5b). The lower Snake River, from the Columbia River confluence near Pasco, Washington, to the Salmon River, Idaho, has a slope of about $0.6 \mathrm{~m} / \mathrm{km}$. The middle portion of the drainage, containing the Hells Canyon Reach, has a higher slope of about $1.4 \mathrm{~m} / \mathrm{km}$. The slope decreases again from Burnt River upriver to Bliss, averaging about $0.5 \mathrm{~m} / \mathrm{km}$. Finally, the slope increases sharply to $>2.0 \mathrm{~m} / \mathrm{km}$ for the next $100 \mathrm{~km}$ upstream of Bliss. Current mainstem spawning areas (i.e., Hanford Reach and Hells Canyon Reach) for fall chinook salmon are also indicated in Figure 1.5. 


\subsubsection{Changes in the Hydrograph}

Hydroelectric development and operation may change the characteristics of the river hydrograph in several different ways. For example, upstream storage practices may influence both the amplitude and shape of the annual discharge regime by changing maximum and minimum discharge, changing the seasonal timing, and altering the shape of extreme flow events. In addition, power peaking operations cause more severe fluctuations in both daily and weekly discharge profiles downstream of projects.

We used the cumulative storage capacity of mainstem and tributary dams to determine appropriate time periods for our analysis of potential changes in the annual hydrograph. For example, major increases in reservoir storage capacity occurred after 1952 and 1975 for the Snake River (Table 1.1). These increases resulted from addition of both mainstem and tributary hydroelectric projects to the system. Significant changes occurred in the mid-Columbia River storage capacity after 1941 and 1967 (Table 1.1). These increases were due to the addition of Grand Coulee Dam and three large Canadian projects, respectively. Data from the lower Columbia River station was segregated into one additional period (1941 to 1952) because of possible influence from upstream storage reservoirs in the Snake River system.

There were no significant differences among the mean monthly values for the three stations and among the different intervals (Table 1.2). However, the annual minimum discharge showed a significant increase for the post-hydroelectric development period at all three monitoring locations. The annual maximum discharge decreased significantly for the two Columbia River stations, but not for Clarkston on the Snake River. The flow amplitude (a measure of relative change in discharge) declined dramatically, as reservoir storage capacity increased, for both Columbia River stations (Table 1.2).

There have been marked differences in the monthly average flows at The Dalles from 1878 to 1998 (Figure 1.6). For example, the annual hydrograph indicates that the average maximum discharge has decreased, and that the average minimum discharge has increased since the hydro-development period. In addition, the annual flow amplitude has decreased over time, indicating that the range in annual flows is much less than what occurred historically (Figure 1.6). This same flow pattern is also evident at Vernita, suggesting that operation of upstream storage dams influences the entire Columbia River (Figure 1.7). In contrast, there have been no obvious changes in the Snake River hydrograph at Clarkston from 1928 to 1998 (Figure 1.8), except that the flow amplitude is significantly lower for the post-1968 interval when compared to 1928 to 1952. This indicates that addition of the Hells Canyon complex and Dworshak Dam has moderated the discharge regime through the lower Snake River.

\subsection{HISTORIC SPAWNING AREAS}

\subsubsection{FALL CHINOOK SALMON}

Little quantitative data exist on the distribution and abundance of fall chinook salmon spawning prior to the mid- $20^{\text {th }}$ century. Several pieces of evidence indicate significant spawning occurred in the Columbia River near the Snake River confluence (DeVoto 1953). For example, Lewis and Clark noted fishing activities and high densities of Native American lodges from the Snake-Columbia confluence to 
Table 1.2. Summary of Discharge Characteristics for Long-Term Monitoring Stations in the Columbia and Snake Rivers. Intervals were based on major changes in cumulative storage capacity. All values are in thousands of cubic feet per second $(\mathrm{kcfs}) \pm 95 \%$ C.I.

\begin{tabular}{|l|l|l|l|l|l|}
\hline \multicolumn{1}{|c|}{ Station } & \multicolumn{1}{|c|}{ Interval } & \multicolumn{1}{|c|}{ Mean Monthly } & $\begin{array}{c}\text { Annual } \\
\text { Minimum }\end{array}$ & $\begin{array}{c}\text { Annual } \\
\text { Maximum }\end{array}$ & $\begin{array}{c}\text { Flow } \\
\text { Amplitude }\end{array}$ \\
\hline Vernita & $1917-1941$ & $112.8 \pm 11.4$ & $33.3 \pm 8.8$ & $323.4 \pm 15.7$ & $10.1 \pm 2.5$ \\
\hline & $1942-1967$ & $125.5 \pm 10.7$ & $56.6 \pm 9.9$ & $345.4 \pm 15.5$ & $5.8 \pm 1.6$ \\
\hline & $1968-1994$ & $116.4 \pm 4.8$ & $76.8 \pm 9.3$ & $186.8 \pm 12.2$ & $2.5 \pm 0.8$ \\
\hline & & & & & \\
\hline Clarkston & $1928-1952$ & $45.8 \pm 4.3$ & $17.6 \pm 1.2$ & $121.3 \pm 17.2$ & $6.9 \pm 0.8$ \\
\hline & $1953-1975$ & $54.1 \pm 4.8$ & $22.3 \pm 1.5$ & $140.4 \pm 17.2$ & $6.3 \pm 0.7$ \\
\hline & $1975-1998$ & $50-4 \pm 4.2$ & $21.9 \pm 2.4$ & $111.7 \pm 16.0$ & $5.1 \pm 0.5$ \\
\hline & & & & & \\
\hline The Dalles & $1878-1941$ & $195.2 \pm 10.5$ & $73.9 \pm 3.5$ & $506.6 \pm 37.5$ & $6.9+0.5$ \\
\hline & $1942-1952$ & $189.8 \pm 23.7$ & $87.1 \pm 7.8$ & $490.1 \pm 91.9$ & $5.7+1.0$ \\
\hline & $1953-1967$ & $193.0 \pm 18.2$ & $101.9 \pm 7.2$ & $488.4 \pm 48.0$ & $4.8 \pm 0.5$ \\
\hline & $1968-1998$ & $185.1 \pm 8.1$ & $111.2 \pm 5.4$ & $320.7 \pm 35.8$ & $2.9 \pm 0.3$ \\
\hline
\end{tabular}

the Yakima River in early October 1804, "the number of dead Salmon on the shores \& floating in the river is incredible...saw great numbers of Dead Salmon on the shores and floating in the water,..." (DeVoto 1953). An important early fishing site for fall chinook salmon during the late $19^{\text {th }}$ century was "Wy-Yow-Na" (Columbia River km 595), a camp where up to 500 tribal members gathered each fall to harvest chinook salmon (U.S. DOI 1942). Gilbert and Evermann (1894) also reported that salmon spawned in "ripples" near the mouths of the Snake and Yakima rivers.

There are also accounts of large numbers of summer/fall chinook salmon migrating to areas upstream of the mid-Columbia region. For example, Gilbert and Evermann (1894) noted that chinook salmon were still abundant at Kettle Falls (rkm 1124) in mid-August 1878, but this run had mostly disappeared by 1890. Chapman (1943) estimated that up to 1,000 chinook salmon still spawned in a 3-km area downstream of Kettle Falls in 1938, with additional spawning occurring at Columbia River kms 1063 and 1093. Before construction of the five mid-Columbia River dams (1955 to 1967), several spawning areas were observed within the approximate $200-\mathrm{km}$ area between Rocky Reach and Grand Coulee dams by Fish and Hanavan (1948) and Edson (1958a, 1958b). In 1946, Fish and Hanaven (1948) counted 785 redds between the mouth of the Snake River and Rock Island Dam, a distance of $216 \mathrm{~km}$. Fulton (1968) reported that a large population of fall chinook salmon spawned in the 160-km stretch of river downstream of McNary Dam. However, neither of the latter two authors described specific spawning locations.

Shoshone Falls (rkm 990) was thought to be the absolute barrier to upstream migration of salmon in the upper Snake River (Gilbert and Evermann 1894). Auger Falls, approximately $16 \mathrm{~km}$ downstream, was passable but "it does not seem possible that many fish would be able to make it through the long series of rapids, although an occasional one does" (Evermann 1896). Downstream of Upper Salmon Falls at rkm $~ 930$ was the "largest and most important salmon spawning ground of which we know in Snake River" (Evermann 1896). Additional spawning beds were said to be present in the vicinity of King Hill 

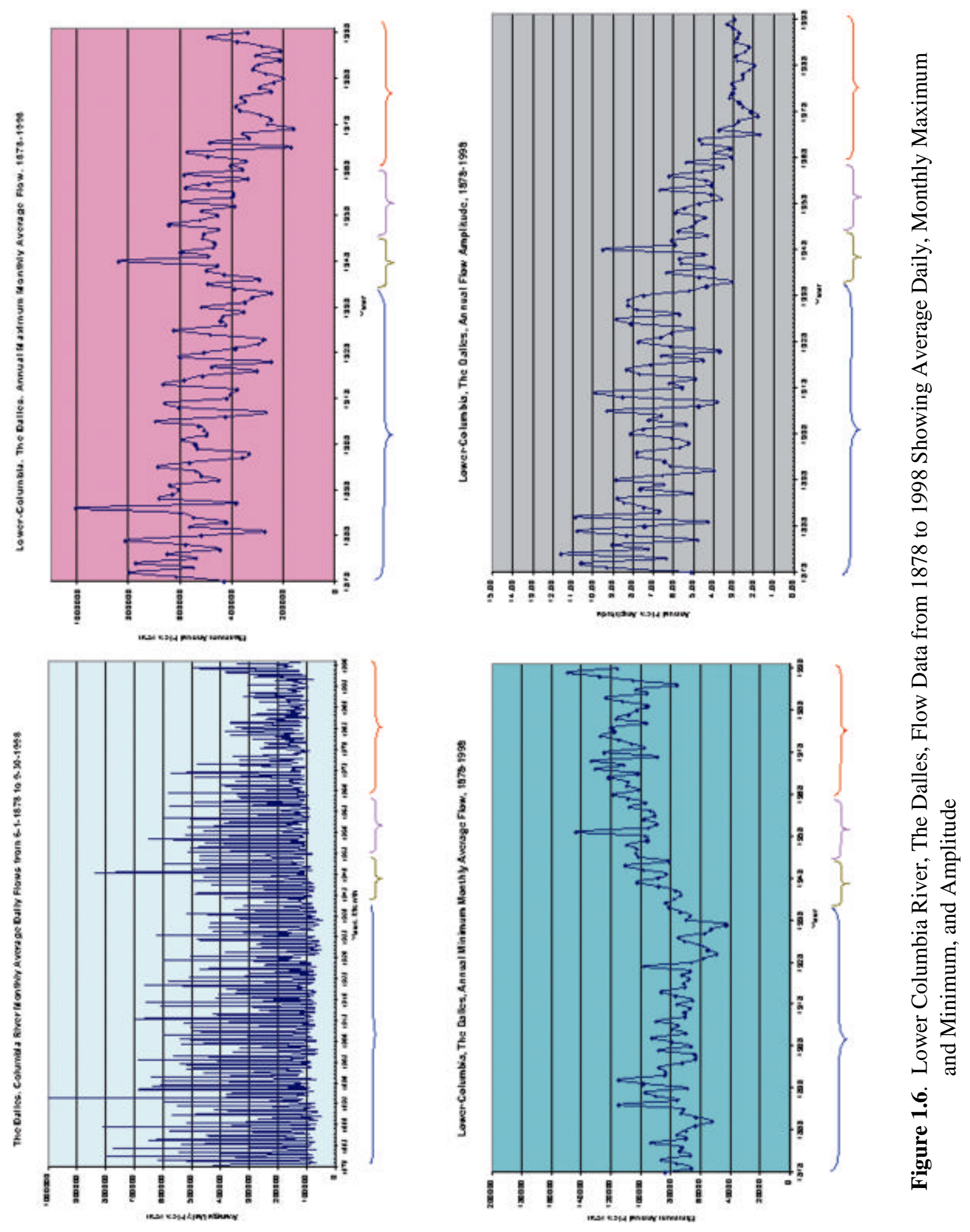

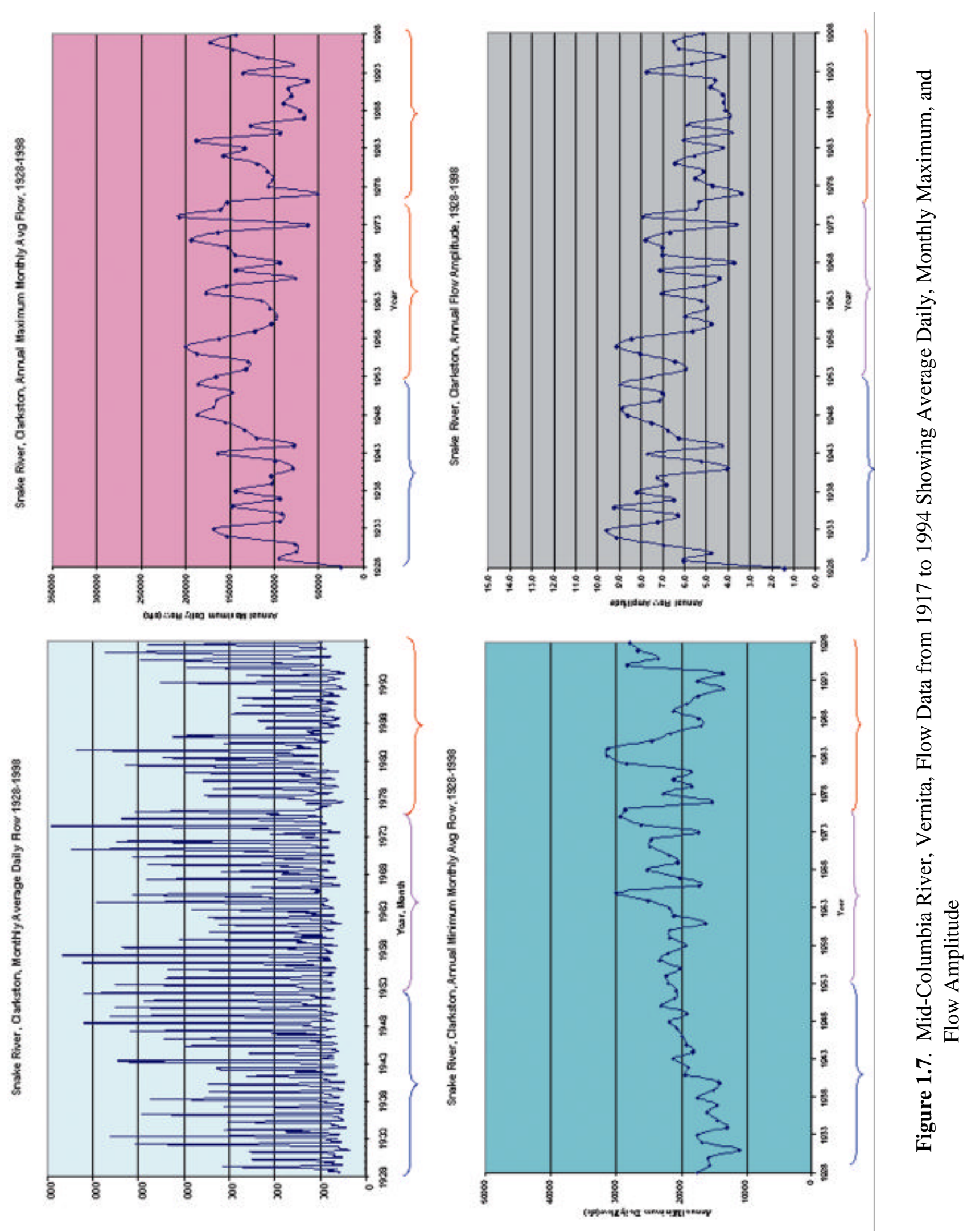

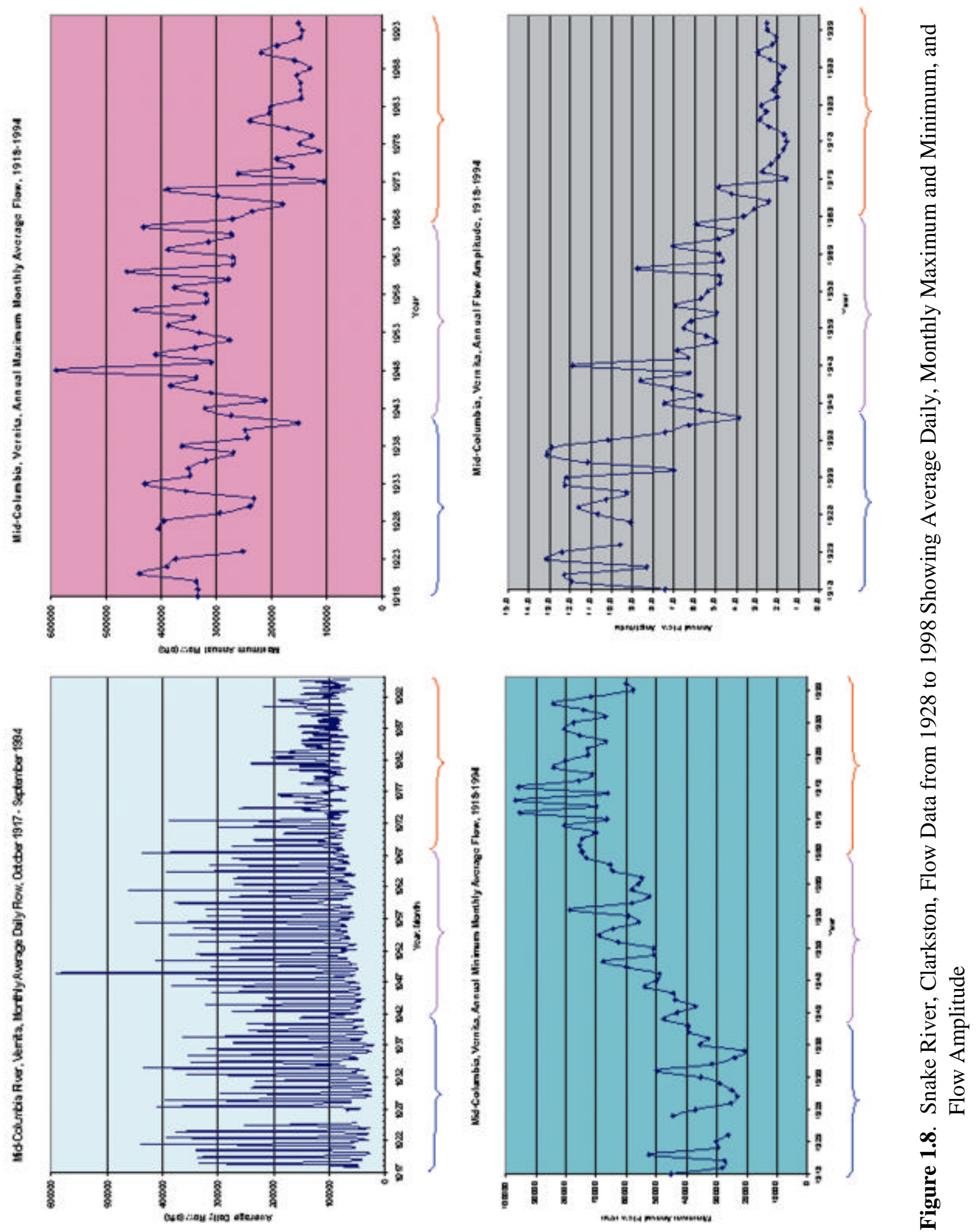
(rkm 878) and Glen Ferry (rkm 867) (Gilbert and Evermann 1894; Evermann 1896). In 1910, construction of Swan Falls Dam at rkm 735 blocked runs of fall chinook salmon that returned to the Snake River upstream of this point. The run was never reestablished, despite improvement of the fishway in 1940 (Fulton 1968). After 1910, upriver areas between Marsing and Weiser, Idaho (rkm 565 to 682), were thought to be particularly important for fall chinook salmon production in the Snake River (Haas 1965; Irving and Bjornn 1981). Parkhurst (1950c), based on a survey conducted in 1942, noted that an 8-km section upstream of Walters Ferry had the best spawning gravels in this area: "This section formerly accommodated a large run of fall chinook salmon, the last good run occurring in 1929 or 1930, according to local residents."

According to Fulton (1968), significant, though scattered, spawning areas were present near the Palouse River junction and near Lewiston, Idaho. Parkhurst (1950a) also reported that extensive salmon spawning areas were present from the mouth of the Snake River to Lewiston, Idaho or a distance of about $225 \mathrm{~km}$. The exact locations were not indicated, nor were species identified. There is no evidence that significant numbers of fall chinook salmon spawned in the section of river now known as the Hells Canyon Reach (Parkhurst 1950b). Bureau of Commercial Fisheries (BCF 1960; cited in Chapman and Witty 1993) also reported redds in the lower Snake River between rkm 11 and 30, before construction of McNary and Ice Harbor dams. These various observations of pre-dam spawning in the lower Snake River were consistent with the size and numbers of subyearling chinook salmon noted at Central Ferry (rkm 132) in 1954 and 1955 by Mains and Smith (1964).

The locations of all known historical spawning locations in the mainstem Columbia and Snake rivers are shown in Figure 1.9, and major spawning areas are summarized in Table 1.3. All known spawning areas are summarized in Appendix A. It is important to note that the level of detail on the distribution and abundance of redds was variable for early reports. For example, some spawning sites were described in great detail, while other sites were only generally described as being present within relatively long stretches of the river. Our best estimate is that fall chinook salmon spawned over a distance of $\sim 600 \mathrm{~km}$ and $\sim 800 \mathrm{~km}$ in the Columbia and Snake rivers, respectively. About $41 \%$ of spawning distance described in the Columbia River and 36\% of the spawning distance described in the Snake River had no information on redd abundance. Thus, these values provide an upper limit on the actual extent of the river channel used for spawning by fall chinook salmon.

\subsubsection{STEELHEAD}

Historical data on important steelhead production areas appears limited to that summarized by Fulton (1970). Based on the distribution of steelhead spawning circa 1970, Fulton reasoned that former spawning areas for steelhead in the mainstem of the Columbia River could have extended from Priest Rapids Dam to the Canadian border (rkm 635 to 1,192), and from approximately $30 \mathrm{~km}$ below Swans Fall Dam to the Bruneau River (rkm 730 to 796) in the mainstem of the Snake River. It is difficult to find primary references to support Fulton's reasoning. Steelhead are mentioned in several historical surveys of the Columbia and Snake rivers, but no mention is made of whether they spawned in mainstem habitats (e.g., Suckley 1860; Gilbert and Evermann 1894; Parkhurst 1950a-c; Bryant and Parkhurst 1950; Edson 1958a, 1958b). Consequently, it is difficult to ascertain if the paucity of data is because steelhead did not spawn in mainstem habitats or because of the difficulty in monitoring steelhead spawning in the mainstem 


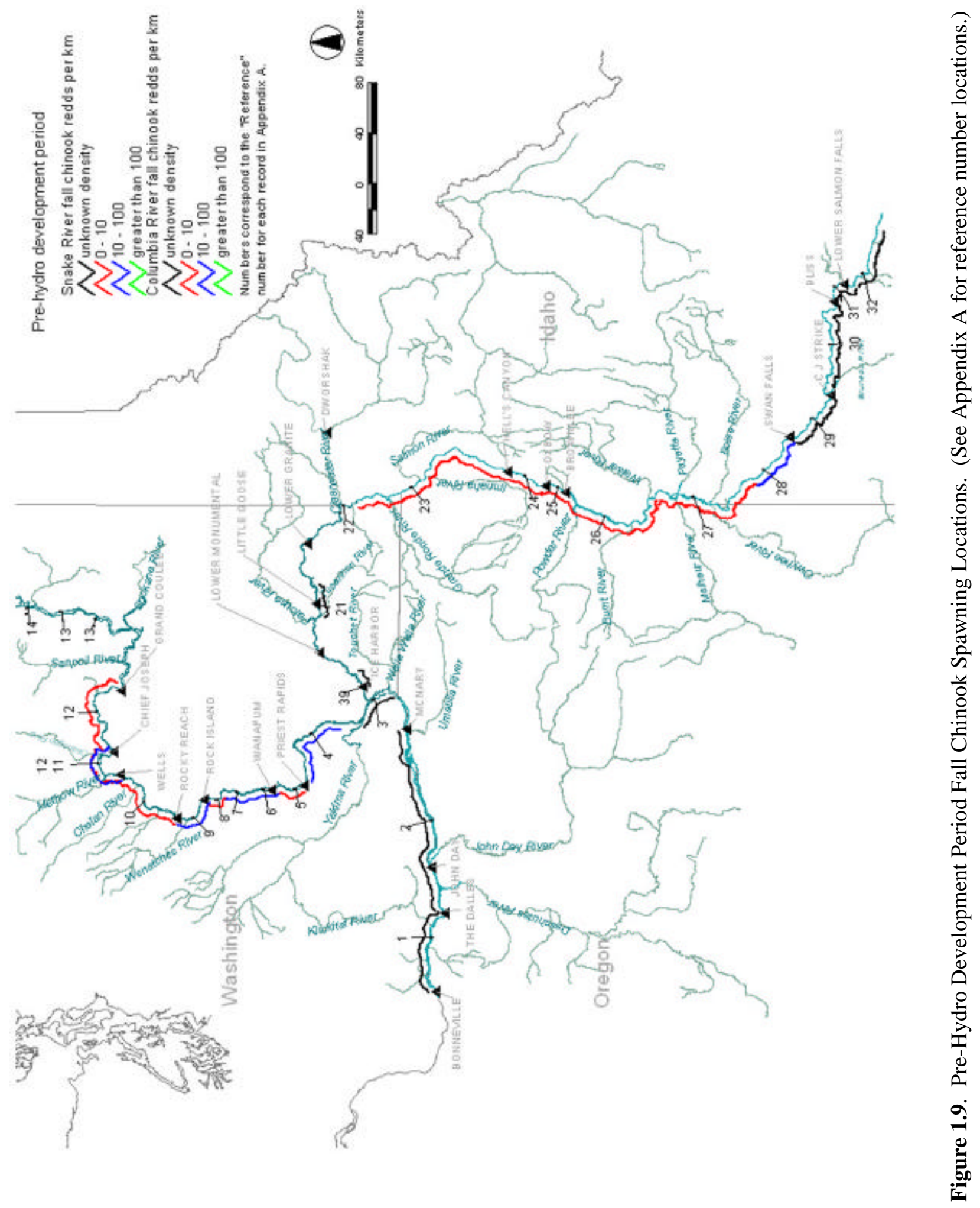


Table 1.3. Summary of Major Historic Spawning Areas for Fall Chinook Salmon in the Mainstem Columbia and Snake Rivers (note that some observations were made during the hydroelectric development period)

\begin{tabular}{|l|l|l|}
\hline \multicolumn{1}{|c|}{$\begin{array}{c}\text { Columbia } \\
\text { River km }\end{array}$} & \multicolumn{1}{|c|}{ Interval } & \multicolumn{1}{c|}{ Reference } \\
\hline $235-308+$ & pre-1968 & unpublished data in Fulton (1968) \\
\hline $309-470$ & pre-1968 & summarized by Fulton (1968) \\
\hline$\sim 540$ vicinity & 1804 & described in DeVoto (1953) \\
\hline $558-630$ & 1947 to present & Dauble and Watson (1997) \\
\hline $663-729$ & $1947-1957$ & Edson (1958a) \\
\hline $763-877$ & $1947-1957$ & Edson (1958b) \\
\hline $809-960$ & 1946 & Fish and Hanavan (1948) \\
\hline $1118-1124$ & $1878-1938$ & Gilbert and Evermann (1894); Chapman (1943) \\
\hline Snake River km & \multicolumn{3}{|l}{} \\
\hline $11-30$ & pre-1954 & BCF (1960) \\
\hline $96-118$ & pre-1968 & summarized by Fulton (1968) \\
\hline$\sim 225$ & pre-1968 & summarized by Fulton (1968) \\
\hline $240-398$ & pre-1968 & summarized by Fulton (1968) \\
\hline $347-439$ & $1957-1969$ & Haas (1965); Irving and Bjornn (1981) \\
\hline $682-737$ & $1957-1969$ & Haas (1965);Irving and Bjornn (1981) \\
\hline $566-983$ & 1894 & Evermann (1896) \\
\hline
\end{tabular}

during high flow conditions. These conditions restrict the ability of fisheries managers to locate and count redds via traditional methods (e.g., aerial surveys). We found no data on steelhead redd densities for any of the areas reported by Fulton (1970) as former spawning locations.

\subsubsection{OTHER ANADROMOUS SALMONIDS}

Coho, sockeye, and spring chinook salmon spawn in tributaries of the Columbia and Snake rivers. They rear in their natal stream or lake system for 1 to 2 years before migrating to the ocean. Use of mainstem habitats by these populations of Pacific salmon is limited to their upstream and downstream migration periods. We found no evidence that these populations spawned in the mainstem Columbia or Snake rivers.

\subsection{CURRENT SPAWNING AREAS}

\subsubsection{FALL CHINOOK SALMON}

About $90 \%$ of the fall chinook salmon that return to the mid-Columbia River now spawn in the Hanford Reach (rkm 549 to 639; Dauble and Watson 1997). The Hanford Reach is the only significant segment of lotic habitat in the mainstem Columbia River upstream of Bonneville Dam. Minor spawning areas for fall chinook salmon are known to occur in the tailrace areas immediately downstream of upstream hydroelectric projects, including Wanapum Dam (rkm 668; Rogers et al. 1989), Rock Island 
Dam (rkm 702; Horner and Bjornn 1979), and Wells Dam (rkm 831; Giorgi 1992). A sizable population of fall chinook salmon, thought to originate from hatchery strays, was recently established downstream of Bonneville Dam (rkm 233; Hymer 1997).

Annual redd counts for the Hanford Reach ranged from 62 to 8,834 during 1948 to 1998. Before extensive hydroelectric development, less than 1,000 redds/year were counted in the Hanford Reach during aerial surveys (Dauble and Watson 1997). Although numbers of redds for the Hanford Reach have fluctuated widely during the last 50 years, the relative proportion of visible redds (i.e., percent of total by area) has been relatively constant within each of the 10 index areas. Fall chinook salmon spawn from about rkm 558 to 630 in the Hanford Reach. However, spawning sites are not continuous, and the actual area used within the river channel is estimated to be only $\sim 3.0 \mathrm{~km}^{2}$ (D.D. Dauble, unpublished data).

Fall chinook salmon that pass Lower Granite Dam on the lower Snake River spawn mainly in the Hells Canyon Reach (Irving and Bjornn 1981; Garcia et al. 1997, 1999). Up to 40\% of the spawning upstream of Lower Granite Dam occurred in major tributaries to the Snake River, including the Grand Ronde, Wallowa, and Clearwater river systems from 1991 to 1996 (A. Garcia, USFWS, personal communication, March 1997). Annual redd counts for the area currently known as the Hells Canyon Reach ranged from 4 to 568 during 1959 to 1978 (Irving and Bjorn 1981; Groves and Chandler 1996). Temporal patterns were difficult to discern because level of effort and methodology often differed among years. However, most spawning appeared to occur in the upper portion of the Hells Canyon Reach before 1980 (Irving and Bjorn 1981). Recent aerial surveys (i.e., 1987 to 1996; Groves and Chandler 1996) were more complete and often included verification of redd locations via ground observations and SCUBA. Redd counts ranged from 45 to 219 during this 10 -year interval. About $62 \%$ of the fall chinook salmon redds ( $\mathrm{n}=708)$ were found in the lower Hells Canyon Reach (rkm 238 to 308) or areas downstream of the Imnaha River. Frequency of use for individual spawning sites was low. Average redd densities were about $0.6 \mathrm{redds} / \mathrm{km} /$ year and $0.3 \mathrm{redds} / \mathrm{km} /$ year for the lower and upper sections, respectively (Groves and Chandler 1996).

From 1993 to 1997, spawning surveys were conducted in the tailraces of the four lower Snake River hydroelectric projects. The primary objective was to determine if apparent loss in adult fall chinook salmon during their upstream migration period could be explained by mainstem spawning. A few fall chinook salmon (<20 redds/year) were found to spawn downstream of Lower Granite, Little Goose, and Ice Harbor dams using underwater video techniques (Dauble et al. 1999). Although within-site fidelity appeared high, frequency of use of known tailrace spawning areas was variable.

The location of current mainstem Snake River spawning areas for fall chinook salmon is shown in Figure 1.10 and summarized in Table 1.4. Information on use of these areas is limited because surveys are not conducted on a regular basis. No comprehensive survey of mainstem habitats has ever been conducted.

Additional populations of fall chinook salmon spawn in tributary streams adjacent to reservoir habitats of the Columbia and Snake rivers (Figure 1.11). In the Columbia River, adult fall chinook return to the Wenatchee, Methow, Okanogan, and Chelan rivers (Chapman et al. 1994); the Yakima River (CTYIN et al. 1990); and the Deschutes, John Day, Wind, Klickitat, and White Salmon rivers (Hymer 


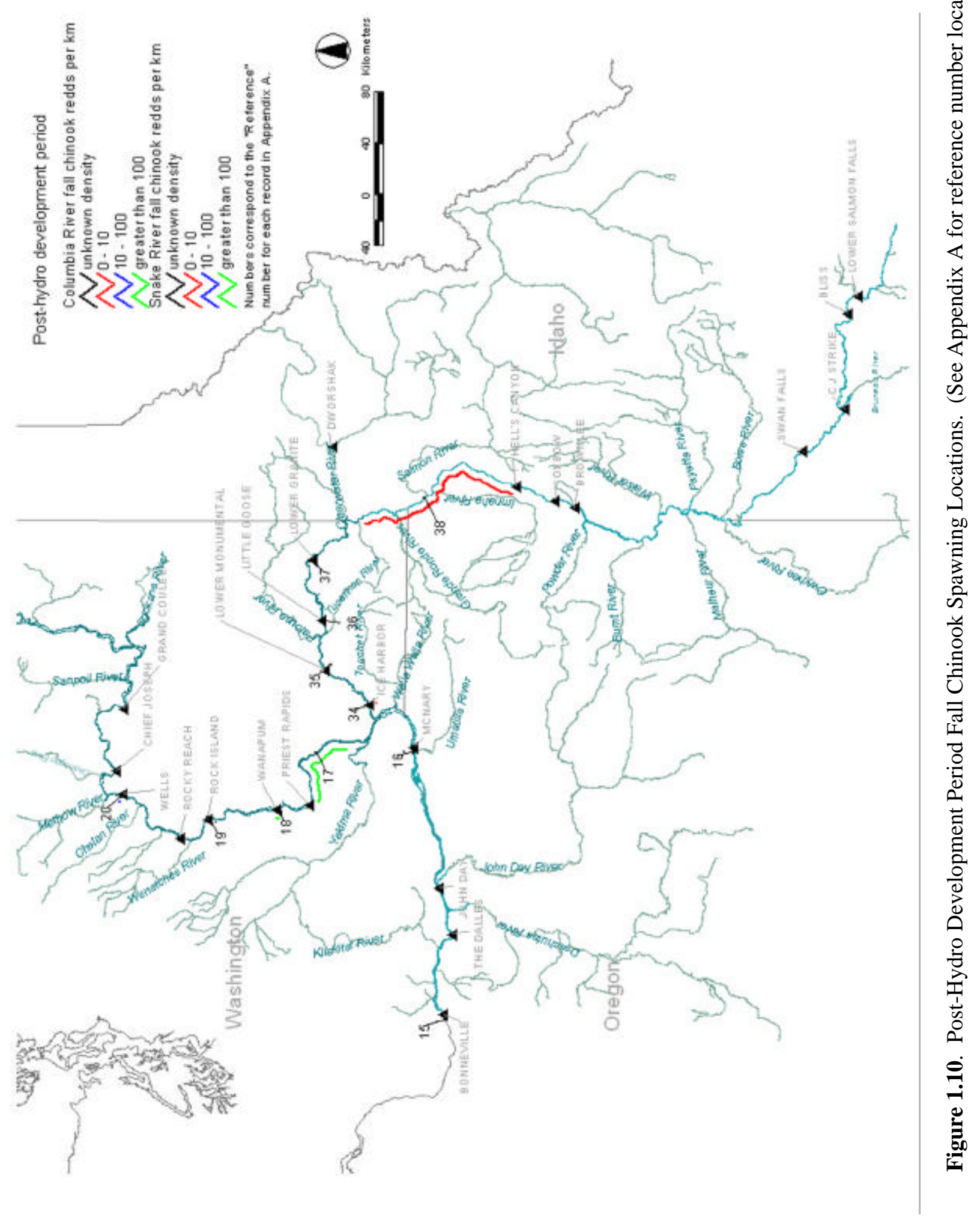


Table 1.4. Summary of Known Spawning Areas for Fall Chinook Salmon in the Mainstem Columbia and Snake Rivers, Post-Hydroelectric Development Period

\begin{tabular}{|l|l|l|}
\hline \multicolumn{1}{|c|}{ Columbia River km } & \multicolumn{1}{c|}{ Interval } & \multicolumn{1}{c|}{ Reference } \\
\hline 232 & $1995-$ present & Hymer (1997) \\
\hline$\sim 468$ & pre-1979 & Horner and Bjornn (1979) \\
\hline $558-630$ & $1947-$ present & Dauble and Watson (1997) \\
\hline $664-666$ & $1986-1991$ & \\
\hline 728 & pre-1979 & Horner and Bjornn (1979) \\
\hline 828 & 1991 & Giorgi (1992) \\
\hline Snake River km & \multicolumn{2}{|l}{} \\
\hline 15 & 1996 & Dauble et al. 1999 \\
\hline$\sim 66$ & 1991 & Kenney (1992) \\
\hline 113 & $1993-1997$ & Dauble et al. 1999 \\
\hline 172 & $1993-1996$ & Dauble et al. 1999 \\
\hline $238-397$ & $1985-1995$ & Groves and Chandler (1996) \\
\hline
\end{tabular}

1992; Beaty 1996). In the Snake River, tributary populations of fall chinook salmon are found in the Clearwater River (B. Arnsberg, personal communication), the Imnaha, Grand Ronde, Salmon (A. Garcia, personal communication), and Tucannon rivers (G. Mendel WDFW, personal communication). Fall chinook salmon populations from the Deschutes, Clearwater, and Yakima rivers are the largest relative to those returning to the Hanford Reach of the Columbia River and Hells Canyon Reach of the Snake River. There are several fall chinook salmon hatcheries and outplanting facilities in the Columbia River system (Figure 1.11; Table 1.5). Adult salmon that return to these hatcheries, as well as those returning to tributaries, could serve as satellite populations for reseeding restored mainstem habitats.

\subsubsection{STEELHEAD}

Little is known about the current levels of steelhead spawning in mainstem habitats of the Columbia and Snake rivers. Fulton (1970) indicated that spawning areas for steelhead in the mainstem Columbia River (circa 1970) were restricted to the Hanford Reach (rkm 558 to 635). It appears this information was based on aerial spawning surveys conducted by the Washington Department of Fish and Wildlife (WDFW) in 1968 and 1970. A total of 220 redds were counted in 1968 and 95 in 1970; total steelhead spawning was estimated to be approximately 2,200 to 25,000 in 1968 and 950 to 7,800 in 1970 (Tony Eldred, personal communication with D.R. Geist, 1989). Approximately 75 steelhead redds were noted during aerial surveys of the Hanford Reach in 1998 (D. Dauble, PNNL, unpublished data). To our knowledge, no other surveys of mainstem habitats for steelhead spawning have been conducted during the post-hydroelectric development period.

That steelhead spawn in the Hanford Reach is supported by other, indirect evidence. Watson (1973) estimated that from 1962 to 1971 an average of 35,000 steelhead trout that annually passed McNary Dam did not pass Priest Rapids Dam on the Columbia River or Ice Harbor Dam on the Snake River. He estimated that 10,000 of these fish were potential spawners in the Hanford Reach, after taking in account reductions due to migration into the Yakima and Walla Walla rivers, sport catch, and natural mortality. Counts from 1977 to 1996 indicated an average of 20,000 steelhead trout that annually passed McNary 


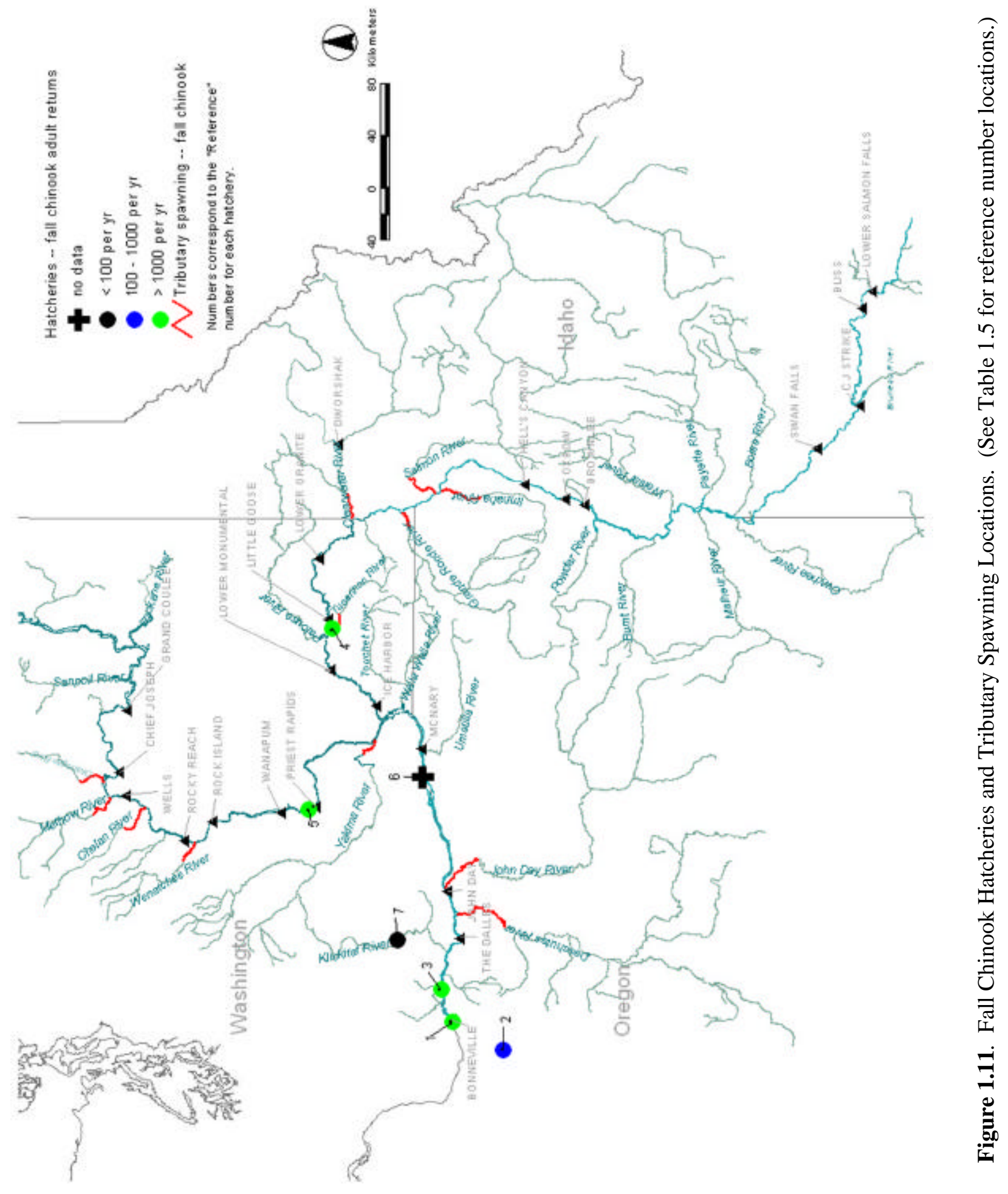


Table 1.5. Fall Chinook Salmon Hatcheries Upstream of Columbia River km 231. ID numbers refer to locations on Figure 1.11.

\begin{tabular}{|l|l|l|l|l|}
\hline \multicolumn{1}{|c|}{ ID } & \multicolumn{1}{|c|}{ Hatchery Name } & \multicolumn{1}{|c|}{ Hatchery Stream } & \multicolumn{1}{c|}{ Service } & Operating Agency \\
\hline 1 & Bonneville & Tanner Creek & 1909 & ODFW \\
\hline 2 & Cascade & Eagle Creek & 1958 & ODFW \\
\hline 3 & Little White Salmon & Little White Salmon & 1898 & USFWS \\
\hline 4 & Lyons Ferry & Snake River & 1983 & WDFW \\
\hline 5 & Priest Rapids & Columbia River & 1963 & WDFW \\
\hline 6 & Irrigon/Umatilla & Columbia River & $1985 / 1991$ & ODFW \\
\hline 7 & Klickitat & Klickitat River & 1951 & WDFW \\
\hline
\end{tabular}

Dam did not pass Ice Harbor or Priest Rapids dams, and approximately 9,000 of these could be potential spawners in the Hanford Reach (Pacific Northwest National Laboratory, unpublished data). Gray and Dauble (1976) collected gravid and ripe females in late April and early May and collected spent males in August within the Hanford Reach.

In the mainstem Snake River, Fulton (1970) reported that current (circa 1970) data showed scattered steelhead spawning upstream from Ice Harbor reservoir to Hells Canyon Dam (rkm 9 to 398). He indicated there were "many good spawning areas in the middle and upriver portions" of the Snake River. As indicated previously, the lack of data on steelhead spawning in mainstem habitats may be due to the fact that they do not extensively use mainstem habitats, or because unfavorable survey conditions present during spawning (e.g., high discharge and increased turbidity) restrict redd observations via aerial surveys.

\subsubsection{OTHER ANADROMOUS SALMONIDS}

Other salmon populations potentially affected by physical habitat modifications to the Columbia and Snake rivers include coho, sockeye, and spring/summer chinook salmon. As noted earlier, their use of mainstem habitats is limited to the adult and juvenile migration periods. There is no evidence that these populations spawned in mainstem habitats.

Radiotracking studies in the Snake River have shown that adult salmon and steelhead migrate faster through reservoir habitats than free-flowing environments (reviewed in PNNL 1995). The principal effects of hydroelectric facilities on migration of adult coho, sockeye, and spring/summer chinook salmon are passage delay and fallback (Dauble and Mueller 1993). There is no evidence that hydroelectric development and/or operation has resulted in a loss of physical habitat required during their upstream migration period. The primary impact to these populations has been from blocked access to former tributary or lake system spawning areas.

\subsection{MIGRATION AND REARING HABITAT}

It is not possible to define specific habitat requirements for salmon smolts because they use the entire cross-section of the river channel while migrating downstream through mainstem habitats. Documented 
migration rates of juvenile salmonids are consistent with activity rhythms that include feeding, quiescent behavior, and active migration (Dauble et al. 1989). These behaviors require that fish inhabit different portions of the river channel, for different reasons.

Studies conducted in the Columbia and Snake rivers before impoundment showed that downstream migrant juvenile salmon are present across the entire river and at all available depths (Mains and Smith 1964). Dauble et al. (1989) found that the spatial distribution of salmonid outmigrants in the Hanford Reach of the Columbia River, the only remaining area in the Columbia River with riverine characteristics, were size related. The larger outmigrants (i.e., yearling chinook salmon, steelhead, and sockeye salmon) occurred mainly near the bottom, mid-channel part of the river, while the smaller wild and hatchery subyearling fall chinook salmon were present in higher densities towards the shoreline. Collectively, these studies suggest that channel features influence smolt distribution in lotic habitats more than depth or velocity (Mains and Smith 1964; Dauble et al. 1989).

Smolts migrating through mainstem reservoirs are typically distributed across the channel, but appear to favor the surface zone. For example, Monan et al. (1969) found highest densities of juvenile salmonids (chinook and coho salmon) in the upper third of Brownlee Reservoir. Smith (1974) also reported that most juvenile salmonids were caught in the upper half of the water column upstream of Lower Monumental Dam. Hydroelectric development has altered seasonal flow patterns and decreased water velocities in the mainstem. These changes have affected both the seasonal timing and length of the downstream migration interval of smolts (Raymond 1979; Bentley and Raymond 1976). However, there is no evidence that the reservoir environment has resulted in loss of the amount of physical habitat required by smolts during their downstream migration period, though it may have changed habitat quality (i.e., velocity, temperature, etc.).

\subsection{CHANGES IN HABITAT AVAILABILITY FOR FALL CHINOOK SALMON}

\subsubsection{SPATIAL ANALYSIS HIERARCHY}

Rivers can be thought of as hierarchically organized geomorphic features arranged predictably within a watershed (Frissell et al. 1986; Schlosser and Angermeier 1995; Imhof et al. 1996). At progressively higher levels of organization, large rivers incorporate a variety of spatial scales. Although most habitat assessments focus on channel or site characteristics, it is well known that habitat hierarchies are spatially nested, i.e., a geomorphic feature at one level affects the form and function of features at a lower level (Frissell et al. 1986; Grant et al. 1990; Gregory et al. 1991). At the watershed scale, the most important physical features that ultimately affect the spawning habitat of fall chinook salmon are the longitudinal slope and flow regimes (Dauble and Geist, in press). This is because the longitudinal slope of a river reflects the long-term geological development of a watershed, and under conditions of uniform discharge,

a direct relationship exists between slope and bed material particle size (Richards 1982). In unconstrained reaches of large gravel- and cobble-bed rivers, the longitudinal slope is reduced and alluvium is deposited (Stanford et al. 1996). This alluvium is highly porous, allowing river water to penetrate into the bed material (hyporheic habitats), creating conditions beneficial to spawning and egg incubation. Thus, 
geologic formations affect longitudinal slope which, along with the flow regime, affects the quality of spawning habitat (i.e., substrate, velocity profiles, etc.) available at the site scale.

At the reach scale, the most important physical features that ultimately affect the spawning habitat of fall chinook salmon are channel morphology and associated hydraulic features. This is because channels that are capable of carrying sediment result in the development of lateral and point bars (Church and Jones 1982). Salmonid spawning usually occurs at the transition between pools to riffles (Bjornn and Reiser 1991), which are areas often associated with a lateral bar deposition area (Church and Jones 1982). Downwelling and upwelling of hyporheic flow occurs at the upstream and downstream portions of a channel bar or island creating interstitial flow pathways through the bed material (Brunke and Gonser 1997). The extent of this upwelling and downwelling is often a function of the channel morphology and flow characteristics (Geist and Dauble 1998).

Examples of reach features in large, alluvial rivers include gravel bars and islands that are longer than one channel width in length. The location and morphology of these features affect specific hydraulic features of the spawning habitat at the "channel unit scale or pool/riffle system" (i.e., distinct hydraulic and geomorphic structures with characteristic bed topography, water surface slope, depth, and velocity patterns) and those at the "sub-unit or micro-habitat" scale (i.e., transitory hydraulic features within a channel unit that have homogenous substrate type, water depth, and velocity).

At the site (i.e., redd) scale, standard habitat characteristics used to describe fall chinook salmon spawning habitat include water depth, substrate size, and velocity (Swan 1989; Chapman et al. 1986; Groves and Chandler, in press). Often these characteristics differ considerably both between and within major spawning areas of similar stocks or races of chinook salmon. For example, water depth over fall chinook salmon redds in the Hanford Reach of the Columbia River has been reported to be from 0.3 to $9.0 \mathrm{~m}$ (Chapman et al. 1986; Swan 1989); substrate particle size ranges from 5 to $30.5 \mathrm{~cm}$ (Swan 1989); and near-bed velocity ranges from 0.4 to $2 \mathrm{~m} / \mathrm{sec}$ (Chapman et al. 1986). Similar variability in physical habitat characteristics has been noted for chinook salmon spawning sites in the Snake River, Idaho (Groves 1993; Connor et al. 1994; Groves and Chandler, in press).

Our habitat evaluation of fall chinook salmon production was restricted to watershed and reach characteristics because historical data on channel bathymetry was available only for short sections of the Columbia River system. A comparative study of current production areas in the Snake and Columbia rivers (Dauble and Geist, in press) demonstrates the importance of geomorphic features to fall chinook salmon spawning. Specifically, longitudinal slope, geology, and the presence of bars and islands were key features of fall chinook salmon spawning areas. We used this information to build a spawning habitat model for predicting where important mainstem production areas might be restored.

\subsubsection{ASSESSMENT OF LOST HABITAT}

We conducted two levels of analysis to assess changes in habitat. The first level of analysis included quantifying lost riverine habitat in terms of lineal distance (river kilometers) of free-flowing river. This iteration assumed that all riverine or free-flowing areas were important to fall chinook salmon production and provided an upper bounds to the estimate of lost production area. It also provided a measure of 
change in riverine habitats available for other life stages of anadromous salmonids (e.g., downstream migration interval of fall chinook, spring chinook, sockeye salmon and steelhead). About $87 \%$ of riverine habitat in the historic mainstem Columbia River and $42 \%$ of riverine habitat in the historic mainstem Snake River have been lost (Table 1.6). The biggest loss of riverine habitat in the Columbia River occurred downstream of the Snake River (rkm 519) where only $3.1 \%$ of the historic riverine habitat still exists, mostly in the tailraces of lower Columbia River hydroelectric projects (not including Bonneville Dam). In contrast, nearly $70 \%$ of the historic riverine habitat remains in the upper Snake River above Hells Canyon Dam (rkm 398), however, this area is not accessible to anadromous salmonids.

\subsubsection{Spawning Habitat}

The next level of analysis included quantifying lost spawning habitat defined by the lineal distance (river kilometers) over which fall chinook salmon spawned before and after hydroelectric development. We determined that approximately 600 and $800 \mathrm{~km}$ of the Columbia and Snake rivers, respectively, were used for spawning (Table 1.6). Before hydro development, our analysis showed that most (80 to 90\%) of

Table 1.6. The Lineal Distance (kilometers) of Potential Spawning Habitat that Existed Before Hydroelectric Development of the Mainstem Snake and Columbia Rivers (historic) Compared to the Amount Currently Available. Riverine habitat is the distance of freeflowing river; actual spawning habitat is the distance over which fish spawned; and predicted spawning habitat is the distance of mainstem habitat predicted as suitable using a geomorphic model based on longitudinal slope, presence of bars and islands, and unconsolidated sediment. The percentages within the current categories represent a comparison to the historic value. Note that anadromous fish cannot migrate upstream of rkm 398 on the Snake River. Lineal Distance $(\mathrm{km})$ of Potential Spawning Habitat.

\begin{tabular}{|c|c|c|c|c|}
\hline Habitat Category & $\begin{array}{l}\text { Lower Col. }^{(\mathbf{a})} \\
\text { (rkm 229-519) }\end{array}$ & $\begin{array}{l}\text { Upper Col. } \\
\text { (rkm 519-964 }\end{array}$ & $\begin{array}{l}\text { Lower Snk. } \\
\text { (rkm 0-398) }\end{array}$ & $\begin{array}{l}\text { Upper Snk. } \\
\text { (rkm 398-994) }\end{array}$ \\
\hline Riverine historic & 289.5 & 445.5 & 397.5 & 597.0 \\
\hline Riverine current & $\begin{array}{c}9.0 \\
(3.1 \%)\end{array}$ & $\begin{array}{c}86.5 \\
(19 \%)\end{array}$ & $\begin{array}{c}164.5 \\
(41.4 \%)\end{array}$ & $\begin{array}{c}415.0 \\
(69.5 \%)\end{array}$ \\
\hline $\begin{array}{l}\text { Actual spawning } \\
\text { habitat - historic }\end{array}$ & 243.5 & 417.5 & 209.5 & 595.5 \\
\hline $\begin{array}{l}\text { Actual spawning } \\
\text { habitat - current }\end{array}$ & $\begin{array}{c}2.0 \\
(<1 \%)\end{array}$ & $\begin{array}{c}83.0 \\
(20 \%)\end{array}$ & $\begin{array}{l}163.0 \\
(78 \%)\end{array}$ & $\begin{array}{c}0 \\
(0 \%)\end{array}$ \\
\hline $\begin{array}{l}\text { Predicted spawning } \\
\text { habitat - historic }\end{array}$ & 94.0 & 189.0 & 131.0 & 180.0 \\
\hline $\begin{array}{l}\text { Predicted spawning } \\
\text { habitat -current }\end{array}$ & $\begin{array}{c}4.5 \\
(4.8 \%) \\
\end{array}$ & $\begin{array}{c}53.5 \\
(28.3 \%) \\
\end{array}$ & $\begin{array}{c}4.5 \\
(3.4 \%) \\
\end{array}$ & $\begin{array}{c}173 \\
(96.1 \%) \\
\end{array}$ \\
\hline \multicolumn{5}{|c|}{$\begin{array}{l}\text { (a) Lower Columbia-just below Bonneville Dam to mouth of Snake River } \\
\text { Upper Columbia-mouth of Snake River to Grand Coulee Dam } \\
\text { Lower Snake-mouth of Snake River to Hells Canyon Dam } \\
\text { Upper Snake-Hells Canyon Dam to Shoshone Falls. }\end{array}$} \\
\hline
\end{tabular}


the historic riverine (i.e., free-flowing) habitat was used for spawning by fall chinook salmon. In contrast, only about $85 \mathrm{~km}$ of the mainstem Columbia River and $163 \mathrm{~km}$ of the mainstem Snake River is currently used for spawning. Essentially, all the current spawning is concentrated in the Hanford Reach and Hells Canyon Reach, although there is a greater amount of high-quality habitat and higher redd densities in the Hanford Reach (Dauble and Geist, in press). Since hydroelectric development, spawning habitat for fall chinook salmon has been reduced to 13 and $20 \%$ of historical habitat in the mainstem Columbia and Snake rivers, respectively.

As noted in Section 1.4, the level of detail for historical spawning data available to perform this analysis was highly variable. Only about $40 \%$ of the data (based on distances) had actual redd counts; the remainder was limited to presence/absence. The actual spawning sites within a reach of river were usually not documented with any precision; rather, the entire reach was stated as a spawning area. This made it impossible to assign a relative value in terms of quality to each of the spawning areas. The highest recorded redd densities for fall chinook salmon in the mainstem Snake River occurred upstream of the Hells Canyon Dam site (reference 28 in Figure 1.9). For example, the section of river between Marsing, Idaho, and Swan Falls Dam (rkm 683 to 737) had spawning densities of 49 redds/km before the hydro development period. This section is now blocked to anadromous fish access. The area upstream of the Swan Falls Dam was another important historic production area (e.g., references 31 and 32 Figure 1.9), but redd densities were not documented before Swan Falls Dam blocking access in the early 1900s. There is no historical evidence that the Hells Canyon Reach was extensively used by fall chinook salmon for spawning before hydro development (Dauble and Geist, in press). This part of the Snake River was used primarily as a migration corridor through which fish passed on their way to upstream and downstream production areas (Parkhurst 1950a). Thus, the total amount of historic spawning habitat (i.e., actual use area) is unknown for the Columbia River Basin.

Spawning locations for fall chinook salmon have been well documented during most of the hydro development period. This information, in addition to surveys conducted after all mainstem hydro projects were completed, provided a means to evaluate the relationship of various geomorphic features to spawning (Figure 1.12). Our spawning habitat model was based on longitudinal gradient $(<0.05 \%)$, geology ( $>50 \%$ unconsolidated), and the presence of bars and islands. These features were found in spawning reaches that contained spawning densities, greater than 10 redds per kilometer (defined as high spawning density areas 4, 6, 7, 9, 11, and 28 from Figure 1.9). When we applied the geomorphic model to the entire Columbia River Basin, it predicted that there were approximately 283 and $311 \mathrm{~km}$ of suitable spawning habitat for fall chinook salmon in the mainstem Columbia and Snake rivers during the pre-development period (Figure 1.12). This distance is about 40 to $50 \%$ less than what was documented as historic spawning habitat (Figure 1.13). When the model was applied to specific river reaches containing the highest known redd densities, it predicted that only 20 to $66 \%$ of the total habitat available for spawning was suitable spawning habitat (Figure 1.14). This analysis suggests that only a portion of river reaches where spawning was thought to occur were actually used. For example, the model predicted that only $58 \mathrm{~km}(60 \%)$ of the free-flowing sections of the mainstem Columbia River (Hanford Reach) were still suitable for spawning, while $\sim 178 \mathrm{~km}$ of free-flowing sections of the present day Snake River was predicted to be suitable spawning habitat. It is important to note that $97 \%$ of this Snake River habitat occurs upstream of present migration barriers to anadromous fish and is unavailable for spawning. None 

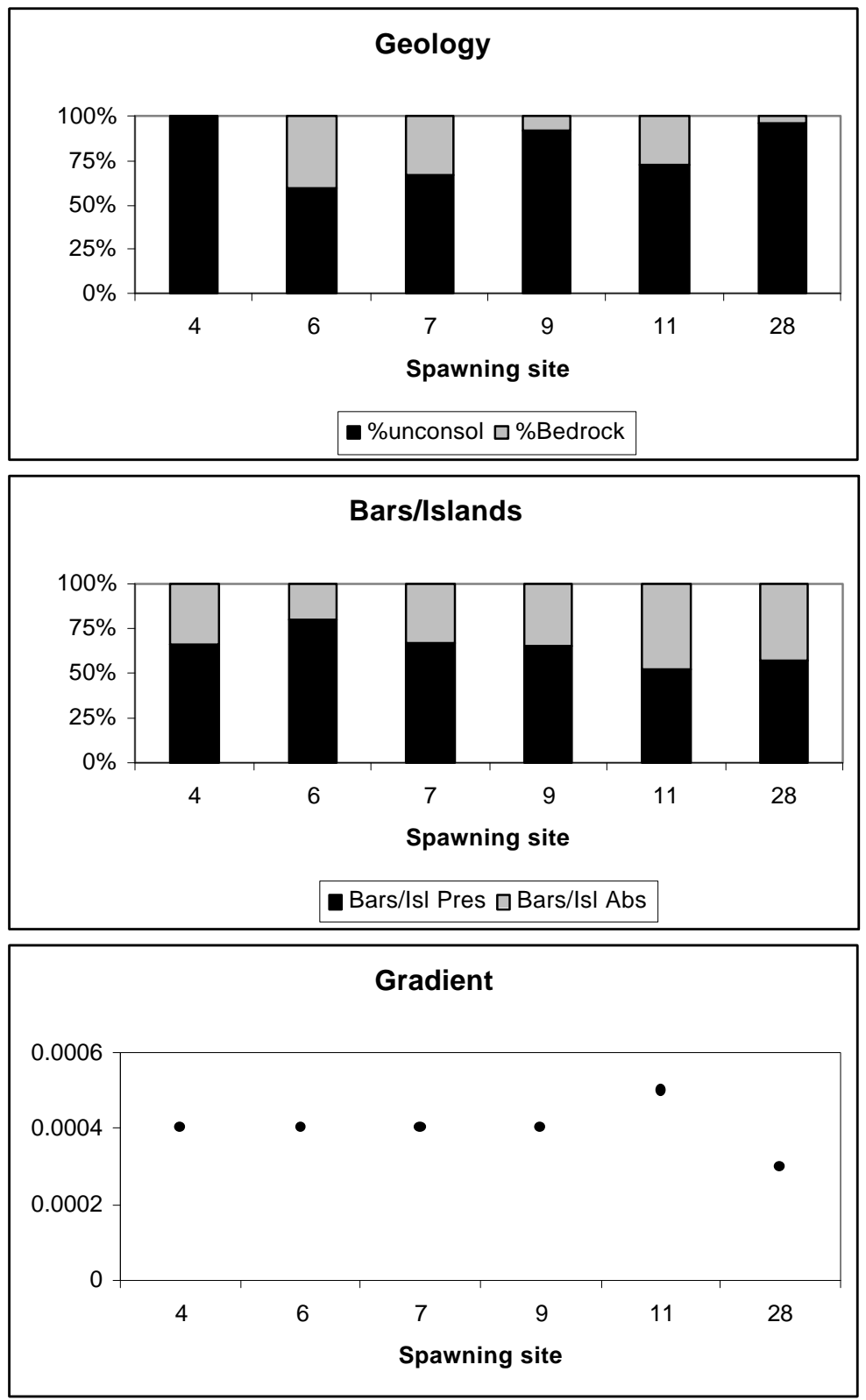

Figure 1.12. Comparison of Geomorphic Features (geology, bars/islands, and longitudinal gradient) in Spawning Sites Documented During the Pre- and Hydro Development Period and With Greater than 10 redds $/ \mathrm{km}$. Spawning sites 4 through 11 are on the mainstem Columbia River with $4=$ Hanford Reach, $6=$ Beverly to Vantage, $7=$ Vantage to Crescent Bar, $9=$ Rock Island Dam to Rocky Reach Dam, and $11=$ Wells Dam to Chief Joseph Dam, and spawning site 28 is on the mainstem Snake River between Marsing Idaho, and Swan Falls Dam. 


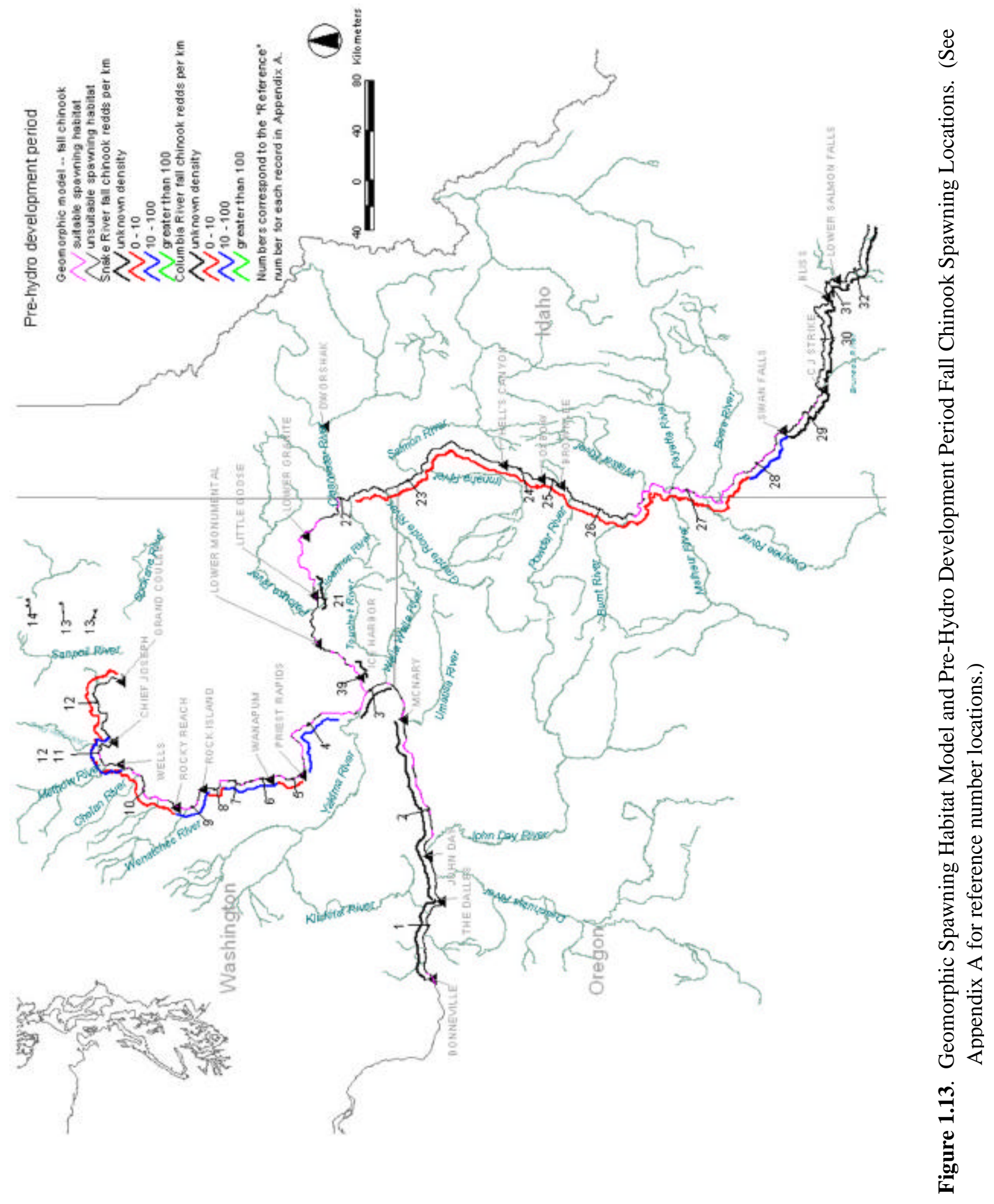




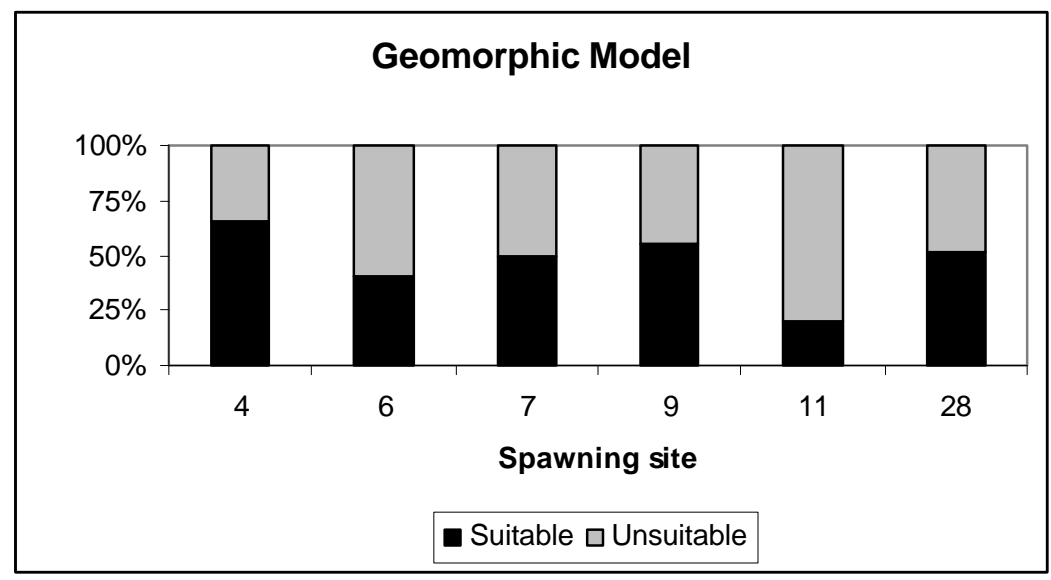

Figure 1.14. Application of the Geomorphic Model (suitable spawning habitat is $>50 \%$ unconsolidated sediment, bars/islands present, and longitudinal slope less than 0.0005) to Spawning Sites Documented During the Pre- and Hydro Development Period with Greater than $10 \mathrm{redds} / \mathrm{km}$. Spawning sites 4 through 11 are on the mainstem Columbia River with 4 = Hanford Reach, 6 = Beverly to Vantage, 7 = Vantage to Crescent Bar, $9=$ Rock Island Dam to Rocky Reach Dam, and $11=$ Wells Dam to Chief Joseph Dam, and spawning site 28 is on the mainstem Snake River between Marsing Idaho, and Swan Falls Dam.

of the Hells Canyon Reach of the Snake River was predicted to be suitable for spawning based on the geomorphic model. Collectively, this information indicates that actual use areas were less extensive then reported by Fulton (1968) and others.

Our analysis substantiated the assertion that historic spawning areas for fall chinook salmon occurred primarily within wide alluvial floodplains that were once common in the mainstem of the Columbia and Snake rivers (Lichatowich and Mobrand 1995; Stanford et al. 1996). These areas tended to possess more unconsolidated sediment, more bars and islands, and lower gradients than areas not extensively used for spawning. Geomorphic features with river floodplains affect the distribution of salmon spawning by creating a mosaic of habitats with different hydrological, physical, chemical, and biotic properties (Stanford et al. 1996). These geomorphic features are connected across spatial scales, with features at one scale affecting the form and function of geomorphic features at a lower level (Frissell et al. 1986; Grant et al. 1990; Gregory et al. 1991). The combination of geomorphic features used in our model reflects this interdependence between different spatial scales. Understanding the geomorphic features of mainstem production areas, in addition to knowledge of hydrologic regimes, provides a means to evaluate management actions for restoring salmon habitats.

\subsubsection{Rearing Habitat}

Because shoreline areas are important to juvenile fall chinook salmon (Dauble et al. 1989; Rondorf et al. 1990) that rear in the mainstem Columbia River, we used shoreline length as an index to quantify changes in potential rearing habitat. This analysis included an estimate of changes in riverine habitat characteristics in terms of the river surface area, length of shoreline, and complexity of channel 
configuration. The estimation of shoreline length for a given river segment included right-bank, left-bank, and islands. Channel complexity is an index representing the unit length of shoreline available for a unit area of surface water (i.e., shoreline length:surface area ratio), with higher index values indicating greater complexity. These measures provide indications of potential habitat changes for fall chinook rearing and staging and feeding areas for other species of anadromous salmonids (i.e., chinook and steelhead) during their downstream migration interval.

The construction of mainstem Columbia and Snake River dams increased the channel's surface area in all segments of the rivers, while also decreasing the amount of shoreline in most segments of the rivers (Table 1.7). Throughout all segments in both rivers, the complexity of the channel decreased from historic levels (Table 1.7). The lower Snake River from its mouth upriver to the confluence of the

Table 1.7. Summary of Surface Area, Shoreline Length, and Channel Complexity for the Mainstem Columbia and Snake Rivers Prior to Hydroelectric Development (historic) and Under Current Conditions

\begin{tabular}{|c|c|c|c|c|c|c|c|}
\hline \multicolumn{2}{|c|}{ River Segment } & \multicolumn{2}{|c|}{$\begin{array}{c}\text { Surface Area } \\
\left(\mathbf{k m}^{2}\right)\end{array}$} & \multicolumn{2}{|c|}{$\begin{array}{c}\text { Shoreline Length } \\
(\mathbf{k m})\end{array}$} & \multicolumn{2}{|c|}{ Complexity Index } \\
\hline From & To & Historic & Current & Historic & Current & Historic & Current \\
\hline \multicolumn{8}{|l|}{ Columbia River } \\
\hline Bonneville & The Dalles & 55 & 76 & 190 & 194 & 3.4 & 2.6 \\
\hline The Dalles & John Day & 18 & 35 & 133 & 97 & 7.4 & 2.7 \\
\hline John Day & McNary & 71 & 197 & 433 & 371 & 6.1 & 1.9 \\
\hline McNary & Snake River confluence & 34 & 109 & 229 & 168 & 6.6 & 1.5 \\
\hline Snake River confluence & Priest Rapids & 53 & 66 & 368 & 355 & 7.0 & 5.4 \\
\hline Priest Rapids & Wanapum & 13 & 31 & 81 & 85 & 6.5 & 2.8 \\
\hline Wanapum & Rock Island & 18 & 57 & 139 & 161 & 7.5 & 2.8 \\
\hline Rock Island & Rocky Reach & 8 & 12 & 73 & 73 & 9.5 & 5.8 \\
\hline Rocky Reach & Wells & 15 & 36 & 157 & 154 & 10.6 & 4.3 \\
\hline Wells & Chief Joseph & 11 & 33 & 107 & 106 & 10.0 & 3.2 \\
\hline Chief Joseph & Grand Coulee & 13 & 32 & 174 & 178 & 12.9 & 5.5 \\
\hline Grand Coulee & Canadian border & 52 & 325 & 593 & 801 & 11.5 & 2.5 \\
\hline \multicolumn{8}{|l|}{ Snake River } \\
\hline Snake River mouth & Ice Harbor & 5 & 8 & 52 & 42 & 11.4 & 5.5 \\
\hline Ice Harbor & Lower Monumental & 12 & 32 & 158 & 110 & 13.0 & 3.5 \\
\hline Lower Monumental & Little Goose & 9 & 26 & 117 & 114 & 12.4 & 4.4 \\
\hline Little Goose & Lower Granite & 14 & 39 & 143 & 137 & 10.2 & 3.5 \\
\hline Lower Granite & $\begin{array}{l}\text { Clearwater River } \\
\text { confluence }\end{array}$ & 10 & 28 & 114 & 107 & 10.8 & 3.8 \\
\hline $\begin{array}{l}\text { Clearwater River } \\
\text { confluence }\end{array}$ & Hells Canyon & 21 & 23 & 374 & 360 & 18.0 & 15.9 \\
\hline Hells Canyon & Oxbow & $*$ & $*$ & $*$ & $*$ & $*$ & $*$ \\
\hline Oxbow & Brownlee & $*$ & $*$ & $*$ & $*$ & $*$ & $*$ \\
\hline Brownlee & Darrows Islands & 17 & 56 & 213 & 399 & 12.8 & 7.2 \\
\hline
\end{tabular}


Clearwater River exhibited the greatest loss of complexity, with the complexity index decreasing from the historic level of 11.5 to the current level of 3.9. Complexity changes in the lower Columbia River were less significant. From Bonneville Dam upriver to the Snake River confluence, the complexity index decreased from the historic level of 5.5 to the current level of 2.0. The Columbia River from the Snake River confluence upriver to Grand Coulee Dam exhibited a complexity index decrease from the historic level of 8.4 to the current level of 4.1. Overall, these data suggest that hydroelectric development has reduced the total amount of available rearing habitat for juvenile anadromous salmonids.

\subsection{DISCUSSION}

Our assessment showed that historic production areas for fall chinook salmon returning to the Columbia River Basin once ranged from near The Dalles, Oregon, upstream to the Pend Oreille and Kootenai rivers in Idaho, and to the Snake River downstream of Shoshone Falls, or a combined distance of almost 1500 km (Gilbert and Evermann 1894; Fulton 1968). However, construction and operation of 36 hydroelectric dams in the mainstem Snake and Columbia rivers between 1907 and 1975 reduced the amount of available spawning habitat to less than $20 \%$ of that distance. Areas with the highest potential for production, still accessible to fall chinook salmon, have been reduced to $\sim 6 \%$ of those present historically. These changes in mainstem habitats have reduced the production capacity of the Columbia River for fall chinook salmon and other anadromous salmonids.

The limited remaining habitat has been further altered by flow regulation that occurred mainly during the latter half of the $20^{\text {th }}$ century. The maximum storage capacity of Columbia River dams now totals 50 million acre-feet (MAF); Snake River dams can store an additional 15 MAF (USACE et al. 1992). Flood control and hydropower loading practices have resulted in a dampening of the seasonal maximum and minimum discharge regimes in the Columbia and Snake rivers. In addition, power peaking operations have increased the weekly and daily fluctuations in water surface elevations throughout the system. One consequence of these flow alterations is a reduction in ability to support natural processes (Stanford et al. 1996; Poff et al. 1997). Because flows in the mainstem are highly regulated, the pre-development alluvial river ecosystem is not expected to be fully restored simply by operational modification of one or more dams.

Construction and operation of low-head reservoirs on the mainstem Columbia and Snake rivers has not produced a significant change in the average temperature of the two rivers (Jaske and Goebel 1963; Perkins and Richmond 1999). However, upstream storage projects have resulted in a delay in the transport of water through the reservoir system (Jaske and Goebel 1963), resulting in a temperature phase shift. This phase shift has implications related to migration timing and spawning. For example, Chapman et al (1994) speculated that fall chinook salmon in the mid-Columbia River now spawn about 1 month later than when Lewis and Clark visited the area. They felt that most spawning formerly occurred in late September and early October, in contrast to current peak spawning of early November, because water temperatures cooled earlier in the year than under current water storage practices. However, they also acknowledged that commercial fisheries in the latter half of the $19^{\text {th }}$ century may have also selectively removed the middle portion of the run (Thompson 1951). Quinn et al. (1997) recently noted that changing flow and temperature regimes over the last several decades has contributed to adult sockeye salmon arriving at Rock Island Dam 14 days earlier from 1933 to 1994. 
Historically, fall chinook salmon existed as a series of local populations that were composed of a larger regional population. The two most important spawning areas before hydroelectric development were thought to occur near the confluence of the Snake and Columbia rivers (US DOE 1942; DeVoto 1953) and upstream of Swan Falls on the Snake River (Evermann 1896). Metapopulation theory suggests that regional populations, such as these formed core areas that supply colonists to remote satellite populations (Rieman and McIntyre 1995). The assumption is that metapopulations overcome extinction risks by incorporating local populations that use more and different habitats. The resiliency of fall chinook salmon populations was evidenced by the presence of many scattered spawning areas throughout the Columbia River Basin. However, construction of mainstem dams fragmented mainstem populations by reducing the flow of colonists between local populations (Lichatowich and Mobrand 1995). The two remaining populations of fall chinook salmon have responded differently to habitat conditions they have been presented with. For example, fall chinook salmon have successfully exploited spawning and rearing habitat in the Hanford Reach as other mainstem production areas became inundated by storage reservoirs upstream of hydropower dams (Dauble and Watson 1997). In contrast, Snake River populations have declined to $<1,500$ adults over the past 10 years and were recently listed as Endangered under the Endangered Species Act.

The geomorphic-based spawning habitat model we used suggests that the upper John Day reservoir, the area adjacent to the Columbia/Walla Walla/Snake/Yakima rivers, and the Little Goose/Lower Granite pools afford the highest potential for restoration of salmon habitats. One additional advantage is the presence of local populations or "potential colonists" of wild or hatchery fish at each of these locations. The presence of tributary and hatchery populations of fall chinook salmon provides opportunities for reseeding restored mainstem habitats, assuming all life history requirements are met. However, it is unlikely that mainstem populations could be enhanced without restoring the riverine processes. This part of the equation would require the timing and magnitude of flushing flows be re-established (Hanrahan et al. 1998).

If anadromous salmonids are successful in mainstem habitats, they must be able to access the different resources required to carry out their life history requirements. In lotic ecosystems, physical habitat structure is of critical importance to the distribution and abundance of organisms (Poff and Ward 1990). Particular resources include suitable conditions for spawning and incubation, low velocity or edge habitats for rearing, and an adequate food supply. Habitat complementation, or the spatial proximity of different resources or habitat types required by a particular species (Dunning et al. 1992; Schlosser 1995), is an important concept to consider when evaluating restoration options. The spatial arrangement among adult holding, adult spawning, and juvenile rearing habitats, for example, would influence the temporal persistence and population size of fall chinook salmon populations. This arrangement appears to be suitable for Hanford Reach populations of fall chinook salmon, but may not be for Snake River populations. Temporal and spatial connectivity (after Stanford and Ward 1993; Poff et al. 1997) between required habitats is also essential to population maintenance and/or rebuilding strategies. Proximity of tributary and hatchery "seed" populations to mainstem habitats with greatest potential for restoration of riverine characteristics should also be considered. It is likely that all salmon populations in the Columbia River Basin will continue to decline unless restorative actions are taken to diversify some portion of mainstem habitats. 
We believe that the rehabilitation of riverine processes and salmon habitats depends on the extent to which alluvial characteristics can be restored. These features must be considered within any future management action, including status quo, reservoir drawdown, removal of hydroelectric projects, and establishment of "normative" flow scenarios (ISG 1996; Stanford et al. 1996). For example, re-establishment of functional floodplains (i.e., through peak flows, is required to scour and rearrange substratum and reconnect floodplain habitats with the channel [Stanford et al. 1996]). Thus, managing toward a more natural flow regime would also cause incremental changes of the river ecosystem toward some semblance of the alluvial attributes. The type and direction of potential changes would be generally predictable based on the range of hydrological conditions and the geomorphological characteristics present. Knowledge of both the historic and current template (i.e., large portions of the river channel have been altered and/or affected by sedimentation) is essential to assessing restoration potential.

Many biotic and abiotic forces shape the survival of anadromous and resident salmonids in the Columbia River Basin. In particular, availability of suitable rearing and migration habitat, including appropriate temperature, water quality, and nutrient regimes must be overlaid against available spawning habitat. For example, the Independent Scientific Group (ISG 1996) speculated that decreased production of aquatic insects and delayed migration resulting from the reservoir environment has affected the relative survival of subyearling fall chinook salmon emigrating from the Hells Canyon Reach of the Snake River. Another consequence of hydro-system development is the proliferation of non-native species (Stanford et al. 1996).

A functional Columbia and Snake river system entails more than merely increased flow rates that would result from dam modification. The climate, geology, and land cover of a catchment basin combine to form the hydrological, physical, chemical, and biotic properties that result in alluvial river ecosystems. Physicochemical factors (e.g., temperature, light intensity, oxygen concentrations) vary longitudinally and horizontally as a result of channel heterogeneity from headwaters to mouth (Townsend 1980). The primary variables driving the distribution and abundance of biota are usually abiotic (e.g., discharge, channel/floodplain geometry, temperature, substrate, nutrients) and are mostly determined by the geologic and climatic setting of the catchment basin (Stanford et al. 1996). In combination, all factors (e.g., hydrology, morphology, physicochemical, etc.) interact to determine the productive capacity of an alluvial river ecosystem. That some factors will still be missing after reservoir drawdown and/or flow manipulation (the most obvious restoration options), suggests that restoration objectives must be well defined.

\subsection{CONCLUSIONS}

It is clear that extensive hydroelectric development has altered mainstem riverine processes and habitat in the Columbia and Snake rivers. These changes have reduced the natural production capacity for all species of anadromous salmonids. Fall chinook salmon populations have been the most impacted by alterations to mainstem ecosystems because of their life-history requirements. Less than $20 \%$ of their historic production areas are available, current spawning areas are largely restricted to two locations, spatial connectivity between required resources is reduced, and remaining production areas are subject to 
highly regulated and variable flow regimes. These physical habitat modifications have also affected ecosystem processes and environmental conditions that influence the success of other salmon and steelhead populations.

We believe the primary actions required for recovery of anadromous salmonids in the Columbia River basin are establishment of natural flow regimes and maintenance of geomorphic features common to alluvial flood plains. Changes that occurred to these essential riverine processes have contributed to significant population declines in fall chinook salmon. Consequently, it is not possible to restore salmon populations without restoring those controlling factors and processes that supported their life history requirements.

The general framework for our assessment was based on developing relationships between attributes of alluvial rivers that are important to salmon production and the controlling factors that create them. This approach has been applied widely to identify habitat needs and management actions for recovery of aquatic systems. By focusing on the relationships between geomorphology and riverine processes affecting salmon habitats, we identified three river reaches downstream of present migration barriers with high potential for restoration: the lower Columbia River upstream of John Day Dam, the ColumbiaSnake-Yakima River confluence, and the lower Snake River upstream of Little Goose Dam. Restoration of any one of these reaches also requires that population genetics and viability of potential seed populations be considered. Establishing more normative flow regimes (i.e., sustained peak flows for scouring) would be essential to restoring the functional characteristics of existing, altered habitats. Finally, restoration goals need to recognize that other ecosystem changes and environmental pressures have reduced the natural production potential of mainstem habitats from that provided by the historic template.

\subsection{REFERENCES}

BCF (Bureau of Commercial Fisheries). 1960. Memo from R. T. Pressey to C. E. Atkinson, E. Mains, R. Larson, D. Marriage, W. Pitney, and F. Hauch, dated Sept. 13, 1960.

Beaty, R.E. 1996. Changes in size and age at maturity of Columbia River upriver bright fall chinook salmon (Oncorhynchus tshawytscha): implications for stock fitness, commercial value, and management. Technical Report 96-7. Columbia River Inter-Tribal Fish Commission. Portland, Oregon.

Bentley, W.W., and H.L. Raymond. 1976. Delayed migrations of yearling chinook salmon since completion of Lower Monumental and Little Goose dams on the Snake River. Transactions of the American Fisheries Society. 105:422-424.

Berggren, T J., and M.J., Filardo. 1993. An analysis of variables influencing the migration of juvenile salmonids in the Columbia River basin. North American Journal of Fisheries Management 13:48-63.

Bjornn, T.C., and D.W. Reiser. 1991. Habitat requirements of salmonids in streams. Pages 83-138 in W.R. Meehan (ed.). Influences of forest and rangeland management on salmonid fishes and their habitats. American Fisheries Society Special Publication 19, Bethesda, Maryland. 
Brunke, M., and T. Gonser. 1997. The ecological significance of exchange processes between rivers and groundwater. Freshwater Biology 37:1-33.

Bryant, F.G., and Z.E. Parkhurst. 1950. Special Scientific Report-Fisheries No. 37. Survey of the Columbia River and Tributaries. Part 4. Area III. Washington streams from the Klickitat and Snake Rivers to Grand Coulee Dam, with notes on the Columbia and its tributaries above Grand Coulee Dam.

Chapman, W.M. 1943. The spawning of chinook salmon in the main Columbia River. Copeia. 1943(3):168-170.

Chapman, D.W. 1986. Salmon and steelhead abundance in the Columbia River in the nineteenth century. Transactions American Fisheries Society 115:662-670.

Chapman, D.W., D.E. Weitkamp, T.L. Welsh, M.B. Dell, and T.H. Schadt. 1986. Effects of river flow on the distribution of chinook salmon redds. Transactions of the American Fisheries Society 115:537547.

Chapman, D.W. and K.L. Witty. 1993. Habitats of weak salmon stocks of the Snake River Basin and feasible recovery measures. Recovery Issues for Threatened and Endangered Snake River Salmon Technical Report 1 of 11. Bonneville Power Administration, Portland, Oregon.

Chapman, D. and 8 coauthors. 1994. Status of summer/fall chinook salmon in the mid-Columbia region. Don Chapman Consultants, Inc., Boise, Idaho.

Church, M., and D. Jones. 1982. Channel bars in gravel-bed rivers. pp 291-338. In R.D. Hey, J.C. Bathurst, and C.R. Thorne (eds) Channel Bar Rivers. John Wiley \& Sons, Ltd. Chichester.

Connor, W.P., A.H. Connor, and R.H. Taylor. 1994. Snake River flows and temperature during the 1992 Snake River fall chinook salmon brood year. Pages 20-38 in D.W. Rondorf and W.H. Miller (eds.). Identification of the spawning, rearing, and migratory requirements of fall chinook salmon in the Columbia River basin. U.S. Department of Energy, Bonneville Power Administration, Portland, Oregon.

Dauble, D.D., and D.R. Geist. Comparison of mainstem spawning habitats for two populations of fall chinook salmon in the Columbia River basin. Regulated Rivers. In press.

Dauble, D.D., and R.P. Mueller. 1993. Factors affecting the survival of upstream migrant adult salmonids in the Columbia River basin. Recovery Issues for Threatened and Endangered Snake River Salmon Technical Report 9 of 11. Bonneville Power Administration, Portland, Oregon.

Dauble, D.D., and D.G. Watson. 1997. Status of fall chinook salmon populations in the mid-Columbia River, 1948-1992. North American Journal of Fisheries Management. 17:283-300.

Dauble, D.D., R.L. Johnson, and A. Garcia. 1999. Fall chinook salmon spawning in tailraces of lower Snake River hydroelectric project. Transactions of the American Fisheries Society. 128:672-679. 
Dauble, D.D., T.L. Page, and R.W. Hanf, Jr. 1989. Spatial distribution of juvenile salmonids in the Hanford Reach, Columbia River. Fishery Bulletin 87:775-790.

DeVoto, B (ed). 1953. The journals of Lewis and Clark. Houghton Mifflin Company, Boston, Massachusetts.

Dunning, J.B., B.J. Danielson, and H.R. Pulliam. 1992. Ecological processes that affect populations in complex landscapes. Oikos 65:169-175.

Ebel, W.J., C.D. Becker, J.W. Mullan, and H.L. Raymond. 1989. The Columbia River-toward a holistic understanding. P. 205-219. In D.P. Dodge (ed) Proceedings of the International Large River Symposium. Canadian Special Publication Fisheries and Aquatic Science 106.

Edson, Q.A. 1958a. Biological Report. Rocky Reach Fisheries Research Program 1958. State of Washington Department of Fisheries. $25 \mathrm{p}+$ attachments.

Edson, Q.A. 1958b. Biological Report. Priest Rapids Fisheries Research Program 1958. State of Washington Department of Fisheries. 15 p.

Evermann, B.W. 1896. A preliminary report upon salmon investigations in Idaho in 1894. Bulletin of the U.S. Fish Commission 15:253-284.

Fish, F.F., and M.G. Hanavan. 1948. A report upon the Grand Coulee Fish-maintenance project 19391947. U.S. Department of Interior Fish and Wildlife Service Special Scientific Report No. 55. 63 p.

Frissell, C.A., W.J. Liss, C.E. Warren, and M.D. Hurley. 1986. A hierarchical framework for stream habitat classification: viewing streams in a watershed context. Environmental Management 10:1099-214.

Fulton, L.A. 1968. Spawning areas and abundance of chinook salmon (Oncorhynchus tshawytscha) in the Columbia River basin-past and present. Unites States Fish and Wildlife Service Special Scientific report-Fisheries No. 571. $26 \mathrm{p}$.

Fulton, L.A. 1970. Spawning areas and abundance of steelhead trout and coho, sockeye, and chum salmon in the Columbia River Basin- past and present. Special Scientific Report Fisheries No. 618. U.S. Department of Commerce, National Oceanic and Atmospheric Administration, National Marine Fisheries Service, Washington, D.C.

Gilbert, C.H., and B.W. Evermann. 1894. A report upon investigations in the Columbia River basin, with descriptions of four new species of fish. Bulletin of the United States Fish Commission 1:169-207.

Garcia, A.P., W.P. Connor, R.D. Nelle, R.D. Waitt, E.A. Rockhold, and R.S. Bowen. 1997. Fall chinook spawning ground surveys in the Snake River, 1995. Pages 1-17 in D.W. Rondorff and K.F. Tiffan (editors). Identification of the spawning, rearing, and migratory requirements of fall chinook salmon in the Columbia River Basin, 1995. Bonneville Power Administration, Portland, Oregon. 
Garcia, A.P., W.P. Connor, R.D. Nelle, R.D. Waitt, R.S. Bowen, T.A. Anderson, and P.E. Bigelow. 1999. Fall chinook salmon spawning around surveys in the Snake River upstream of Lower Granite Dam, 1996. Pages 1-22 in K.F. Tiffan, D.W. Rondorff, and H.L. Burge (editors). Identification of the spawning, rearing, and migratory requirements of fall chinook salmon in the Columbia River Basin, 1996-1997. Bonneville Power Administration, Portland, Oregon.

Geist, D.R., and D.D. Dauble. 1998. Redd site selection and spawning habitat use by fall chinook salmon: the importance of geomorphic features in large rivers. Environmental Management 22:655-669.

Gilbert, C.H., and B.W. Evermann. 1894. A report upon investigations in the Columbia River basin, with descriptions of four new species of fish. Bulletin of the United States Fish Commission 1:169-207.

Giorgi, A.E. 1992. Fall chinook salmon spawning in Rocky Reach pool: effects of a three foot increase in pool elevation. Research report to Chelan County Public Utility District.

Grant, G.E, F.J. Swanson, and M.G. Wolman. 1990. Pattern and origin of stepped-bed morphology in high-gradient streams, western Cascades, Oregon. Geological Society of American Bulletin 102:340-352.

Gregory, S.V., F.J. Swanson, W.A. McKee, and K.W. Cummins. 1991. An ecosystem perspective of riparian zones. BioScience 41:540-551.

Gray, R.H., and D.D. Dauble. 1976. Synecology of the Fish Community Near Hanford Generating Project and Assessment of Plant Operational Impacts, pp. 5.1 to 5.55. In: Final Report on Aquatic Ecological Studies Conducted at the Hanford Generating Project, 1973-1974. WPPSS Columbia River Ecology Studies Vol. 1. Prepared for Washington Public Power Supply System under Contract No. 2311201335 with United Engineers and Constructors, Inc., by Battelle, Pacific Northwest Laboratories, Richland, Washington. 216 pp.

Groves, P.A. 1993. Habitat available for, and used by, fall chinook salmon within the Hells Canyon Reach of the Snake River. Annual Progress Report 1992. Idaho Power Company, Boise, Idaho.

Groves, P.A., and J.A. Chandler. 1996. A summary of fall chinook salmon (Oncorhynchus tshawytscha) redd surveys within the Hells Canyon Reach of the Snake River, Idaho; 1991-1995. Idaho Power Company. Boise, Idaho.

Groves, P., and J. Chandler. 1999. Spawning habitat used by fall chinook salmon in the Snake River. North American Journal of Fisheries Management 19:912-922.

Haas, J.B. 1965. Fishery problems associated with Brownlee, Oxbow, and Hells Canyon Dams on the middle Snake River. Investigational Report No. 4. Fish Commission of Oregon. Portland, Oregon. $95 \mathrm{p}$. 
Hanrahan, T.P., D.A. Neitzel, M.C. Richmond, and K.A. Hoover. 1998. Assessment of drawdown from a geomorphic perspective using geographic information systems: Lower Snake River, Washington, Final Report to U.S. Army Corps of Engineers, Walla Walla District.

Horner, N., and T.C. Bjornn. 1979. Status of upper Columbia River fall chinook salmon (excluding Snake River populations). Idaho Cooperative Fishery Research Unit, University of Idaho, Moscow, Idaho. $45 \mathrm{p}$.

Hymer, J. 1992. Washington Columbia River and tributary stream survey sampling results, 1991. Columbia River Laboratory Progress Report 92-25. Washington Department of Fisheries. Battle Ground, Washington.

Hymer, J. 1997. Results of studies on chinook spawning in the mainstem Columbia River below Bonneville Dam. Columbia River Progress Report 97-9. Washington Department of Fish and Wildlife. Battle Ground, Washington.

Imhof, J.G., J. Fitzgibbon, and W.K. Annable. 1996. A hierarchical evaluation system for characterizing watershed ecosystems for fish habitat. Canadian Journal of Fisheries and Aquatic Sciences 53(Suppl.1):312-326.

Irving, J.S., and T.C. Bjornn. 1981. Status of Snake River fall chinook salmon in relation to the Endangered Species Act. Idaho Cooperative Fishery Research Unit, University of Idaho, Moscow, Idaho. $55 \mathrm{p}$.

Independent Scientific Group (ISG). 1996. Return to the river, restoration of salmonid fishes in the Columbia River ecosystem. Pre-publication copy dated September 10, 1996. Northwest Power Planning Council, Portland, Oregon.

Jaske, R.T., and J.B.Goebel. 1963. Effects of dam construction on temperatures of the Columbia River. Journal of the American Water Works Association 59:935-942.

Johnson, B. R., and G. L. Raines. 1996. Digital representation of the Idaho state geologic map: A contribution to the Interior Columbia River Basin Ecosystem Management Project, Open File Report 95690, U.S. Geological Survey.

Kellerhals, R., M. Church, and D.I. Bray. 1976. Classification and analysis of river processes, Journal of the Hydraulics Division, Proceedings of the American Society of Civil Engineers, 102(HY7), 813-829.

Kellerhals, R., and M. Church. 1989. The morphology of large rivers: characterization and management. Pages 31-48 in D.P. Dodge (ed.). Proceedings of the International Large River Symposium. Canadian Special Publication of Fisheries and Aquatic Sciences 106, Department of Fisheries and Oceans, Ottawa, Canada. 
Kenney, D. 1992. Memorandum on fish eggs and fry recovered in dredged material below Lower Monumental Project. U.S. Army Corps of Engineers, Walla Walla District, Walla Walla, Washington.

Lichatowich, J.A., and L.E. Mobrand. 1995. Analysis of chinook salmon in the Columbia River from an ecosystem perspective. Report to U.S. Department of Energy. DOE/BP-25105, Bonneville Power Administration. Portland, Oregon.

Mains, E.M., and J.M. Smith. 1964. The distribution, size, time, and current preferences of seaward migrant chinook salmon in the Columbia and Snake rivers. Washington State Department of Fisheries Research Papers 2:5-43.

Monan, G.E., R.J. McConnell, J.R. Pugh, and J.R. Smith. 1969. Distribution of debris and downstreammigrating salmon in the Snake River above Brownlee Reservoir. Transactions of the American Fisheries Society 98(2):239-244.

Northwest Power Planning Council (NPPC). 1986. Compilation of information on salmon and steelhead losses in the Columbia River Basin. Appendix D of the 1987 Columbia River Basin Fish and Wildlife Program. Portland, Oregon.

Parkhurst, Z.E. 1950c. Special Scientific Report-Fisheries No. 57. Survey of the Columbia River and Tributaries. Part 8. Area VII. Snake River, above Payette River to upper Salmon Falls. U.S. Fish and Wildlife Service. Washington, D.C.

Parkhurst, Z.E. 1950b. Special Scientific Report-Fisheries No. 40. Survey of the Columbia River and Tributaries. Part 7. Area VI. Snake River from above the Grande Ronde River through the Payette River. U.S. Fish and Wildlife Service. Washington, D.C.

Parkhurst, Z.E. 1950a. Special Scientific Report-Fisheries No. 39. Survey of the Columbia River and Tributaries. Part 6. Area V. Snake River system from the mouth through the Grande Rhonde River. U.S. Fish and Wildlife Service. Washington, D.C.

Perkins, W.A., and M.C. Richmond. 1999. Long-term, one-dimensional simulation of lower Snake River temperatures for current and unimpounded conditions. Draft Report. Pacific Northwest National Laboratory. Richland, Washington.

PNNL (Pacific Northwest National Laboratory). 1995. Biological Plan-Lower Snake River Drawdown. Technical Report Appendix G to Columbia River Salmon Mitigation Analysis System Configuration Study Phase I. Prepared for U.S. Army Corps of Engineers, Walla Walla, Washington.

Poff, N.L., and J.V. Ward. 1990. Physical habitat template of lotic systems: recovery in the context of historical pattern of spaiotemporal heterogeneity. Environmental Management 14:629-645.

Poff, N.L., and 7 coauthors. 1997. The natural flow regime. BioScience 47:769-784. 
Quinn, T.P., S. Hodgson, and C. Peven. 1997. Temperature, flow, and the migration of adult sockeye salmon (Oncorhynchus nerka) in the Columbia River. Canadian Journal of Fisheries and Aquatic Sciences 54:1349-1360.

Raines, G.L., and B.R. Johnson. 1996. Digital representation of the Washington state geologic map: A contribution to the Interior Columbia River Basin Ecosystem Management Project, Open File Report 95684, U S. Geological Survey.

Raymond, H.L. 1979. Effects of dams and impoundments on migrations of juvenile chinook salmon and steelhead from the Snake River, 1966 to 1975. Transactions of the American Fisheries Society 108:505529.

Raymond, H.L. 1988. Effects of hydroelectric development and fisheries enhancement on spring and summer chinook salmon and steelhead in the Columbia River basin. North American Journal of Fisheries Management 8:1-24.

Richards, K. 1982. Rivers form and process in alluvial channels. Methuen, London and New York.

Rogers, L.E., P.A. Beedlow, L.E. Eberhardt, D.D. Dauble, and R.E. Fitzner. 1989. Ecological Baseline Study of the Yakima Firing Center Proposed Land Acquisition A Status Report. PNL-6485. Pacific Northwest Laboratory, Richland, Washington.

Rieman, B.E., and J.D. McIntyre. 1995. Occurrence of bull trout in naturally fragmented habitat patches of varied size. Transactions of the American Fisheries Society 124:285-296.

Rondorf, D.W., G.A. Gray, and R.B. Fairley. 1990. Feeding ecology of subyearling chinook salmon in riverine and reservoir habitats of the Columbia River. Transactions of the American Fisheries Society. 119:16-24.

Schlosser, I.J. 1995. Stream fish ecology: a landscape perspective. BioScience 41:704-711.

Schlosser, I.J., and P.L Angermeier. 1995. Spatial variation in demographic processes of lotic fishes: conceptual models, empirical evidence, and implications for conservation. American Fisheries Society Symposium 17:392-401.

Smith, J.R. 1974. Distribution of seaward-migrating chinook salmon and steelhead trout in the Snake River and Lower Monumental Dam. Marine Fisheries Review 36(8):42-45.

Smith, C.L. 1979. Salmon fishers of the Columbia. Oregon State University Press, Corvallis, Oregon. $117 \mathrm{p}$.

Stanford, J.A., and J.V. Ward. 1993. An ecosystem perspective of alluvial rivers: connectivity and the hyporheic corridor. Journal of the North American Benthological Society 12:48-60. 
Stanford, J.A., J.V. Ward, W.J. Liss, C.A. Frissell, R.N. Williams, J.A. Lichatowoch, and C.C. Coutant. 1996. A general protocol for restoration of regulated rivers. Regulated Rivers: Research \& Management 12:391-413.

Suckley, G. 1860. No. 5. Report upon the fishes collected of the survey. Chapter I. Report upon the Salmonidae. In Explorations and Surveys to Ascertain the most practicable and economical route for a railroad from the Mississippi River to the Pacific Ocean. Made under the direction of the Secretary of War, in 1853-5, according to acts of Congress of March 3, 1853, May 31, 1854, and August 5, 1954. Volume XII. Book II. Senate 36th Congress 1st Session. Washington.

Swan, G.A. 1989. Chinook salmon spawning surveys in deep waters of a large, regulated river. Regulated Rivers: Research \& Management 4:355-370.

Thompson, W.F. 1951. An outline for salmon research in Alaska. University of Washington, Fisheries Research Institute Circular No. 18: 49 p.

Townsend, C.R. 1980. The ecology of streams and rivers. Studies in Biology No. 122. Edward Arnold, London. $68 \mathrm{pp}$.

U.S. Army. 1952. Columbia River and tributaries, northwestern United States. Letter from the Secretary of the Army. Volume VII. House Document No. 531. Washington, D.C.

USACE, BPA, and BOR (U.S. Army Corps of Engineers, Bonneville Power Administration, and Bureau of Reclamation). 1992. Columbia River Salmon Flow Measures Options Analysis/EIS.

USACE (U.S. Army Corps of Engineers). 1994. Columbia River Salmon Mitigation Analysis System Configuration Study Phase I. Lower Snake Reservoir Drawdown. Technical Report Appendix A.

USDOI (U.S. Department of the Interior). 1942. Report on the sources, nature, and extent of the fishing, hunting, and miscellaneous related rights of certain Indian tribes in Washington and Oregon together with affidavits showing locations of usual and accustomed fishing grounds and stations. Office of Indian Affairs Los Angeles, California.

van der Leen, F., F.L. Troise, and D.K Dodd. 1990. The Water Encyclopedia. 2nd edition. Lewis Publishers. Chelsea, Michigan.

Van Hyning, J.M. 1973. Factors affecting the abundance of fall chinook salmon in the Columbia River. Research Reports of the Fish Commission of Oregon 4:1-87.

WDFW/ODFW (Washington Department of Fisheries and Wildlife/Oregon Department of Fisheries and Wildlife). 1996. Status Report. Columbia River Fish Runs and Fisheries 1938-95. 194 p. 
Watson, D.G. 1973. Estimate of steelhead trout spawning in the Hanford Reach of the Columbia River. Report to U.S. Army Corps of Engineers by Battelle Pacific Northwest Laboratories, Richland, Washington. 


\section{CHAPTER TWO \\ OPTIONS FOR RESTORATION OF MAINSTEM HABITATS}

\subsection{INTRODUCTION}

As part of this project, the Northwest Power Planning Council (NWPPC) asked the Battelle/USGS research team to develop a list of mainstem restoration options. We chose to develop that list by soliciting input from regional experts. In August 1999, we held a 1-day workshop in Richland, Washington, to discuss potential options for restoring mainstem habitats of salmon and resident fish in the Columbia River basin. The list of invitees (see Appendix B) was limited to individuals in the region who have been or currently are involved with regional assessments of hydrosystem operations and their impacts on mainstem aquatic habitats. The intent was to focus on scientific issues related to restoration of riverine processes, rather than issues related to resource management, policy, and/or socioeconomics.

The goal of the workshop was to provide a detailed summary of possible options and locations for restoring mainstem habitats, including 1) potential risks and benefits to existing ecosystems (including reservoir systems upstream of current barriers to anadromous fish migration), 2) a ranked order of options with the highest potential to restore riverine processes important to salmon production, and 3) a list of key uncertainties related to the options of choice. The general process for conducting the workshop involved a review of overall project goals, initial brainstorming of restoration options, identification of related questions and issues, development of criteria for ranking options, discussion of restoration options, and final prioritization of options. A facilitator helped focus discussions on project objectives.

\subsection{IDENTIFICATION OF RESTORATION OPTIONS}

Participants were first asked to identify and briefly describe possible restoration options, including what action needed to occur, where it would be implemented, and over what time frame (e.g., immediately, phased, permanent). The participants were asked to identify options regardless of the perceived social, political, or economic costs of the activity. After each participant had the opportunity to identify potential restoration options, like options were combined into six general categories for further discussion. This provided a comprehensive list of 30 restoration options. The six categories covered a wide range of activities, including options ranging from complete restoration of riverine functions by removing various dams to no change in existing physical configuration and controlling non-native fish species (Table 2.1).

Risks and benefits of the 30 specific options for restoring mainstem habitat listed in Table 2.1 are described in Table 2.2. All the dam removal and reservoir drawdown options, and most of the flow and engineered options, provided benefits related to increased production of fall chinook salmon. Two major risks for dam removal included decreased water quality and possibly decreased juvenile survival if transportation programs were eliminated. Some flow options were also thought to have risks to water quality. The greatest uncertainties associated with risks and benefits were with engineered "fixes" of mainstem habitats (Table 2.2). 
Table 2.1. Initial List of Options for Restoring Mainstem Habitats of the Columbia and Snake Rivers

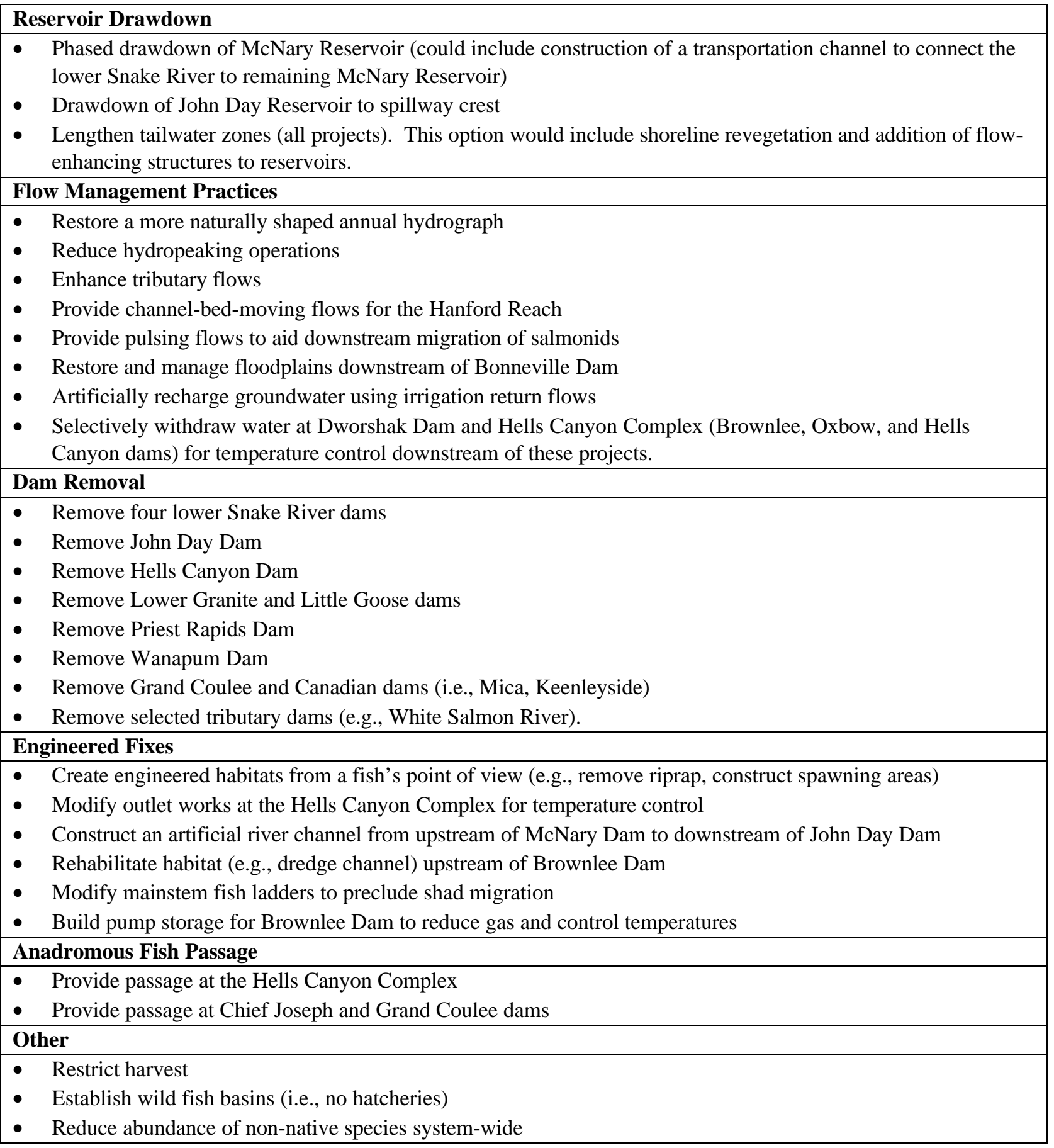


Table 2.2. Risks and Benefits of Different Restoration Options to Juvenile and Adult Anadromous Salmonids in Existing Aquatic Ecosystems and to Resident Salmonids Present in Reservoir Systems Upstream of Current Barriers to Anadromous Fish Migration.

\begin{tabular}{|c|c|c|}
\hline Dam Removal Options & Risks & Benefits \\
\hline $\begin{array}{l}\text { Remove all four lower Snake } \\
\text { River dams }\end{array}$ & $\begin{array}{l}\text { Eliminates the ability to transport } \\
\text { juvenile salmonids. }{ }^{\text {(a) }}\end{array}$ & $\begin{array}{l}\text { Expands production areas for fall } \\
\text { chinook salmon. Reduces the number } \\
\text { of passage barriers to migrating adults. } \\
\text { Decreases travel time of juveniles } \\
\text { through the lower Snake River. } \\
\text { Depending on species and site-specific } \\
\text { issues related to juvenile transportation } \\
\text { program, this may either increase or } \\
\text { decrease juvenile survival. }\end{array}$ \\
\hline Remove John Day Dam & $\begin{array}{l}\text { Eliminates the ability to transport } \\
\text { juvenile salmonids. }{ }^{\text {(a) }}\end{array}$ & $\begin{array}{l}\text { Improves conditions for adult salmonid } \\
\text { migration. Expands current production } \\
\text { areas for fall chinook salmon. }\end{array}$ \\
\hline $\begin{array}{l}\text { Remove Hells Canyon Dam } \\
\text { complex }\end{array}$ & $\begin{array}{l}\text { Risk to juvenile survival and } \\
\text { production from passage mortality } \\
\text { and negative effects on water } \\
\text { quality. }\end{array}$ & $\begin{array}{l}\text { Allows access of fall chinook salmon to } \\
\text { former production areas. Increases } \\
\text { connectivity of habitats used by resi- } \\
\text { dent fish. }\end{array}$ \\
\hline $\begin{array}{l}\text { Remove Lower Granite and } \\
\text { Little Goose dams }\end{array}$ & $\begin{array}{l}\text { Eliminates the ability to transport } \\
\text { juvenile salmonids. }\end{array}$ & $\begin{array}{l}\text { Increases production of fall chinook } \\
\text { salmon; increases juvenile survival } \\
\text { (however, see option above for all four } \\
\text { lower Snake River dams). }\end{array}$ \\
\hline Remove Priest Rapids Dam & None identified. & $\begin{array}{l}\text { Improves migration conditions for } \\
\text { adults and juveniles. Extends current } \\
\text { production areas for fall chinook } \\
\text { salmon. Increases juvenile survival by } \\
\text { providing increased rearing areas. } \\
\text { Improves water quality (i.e., reduced } \\
\text { temperature and dissolved gas) through } \\
\text { elimination of reservoir. }\end{array}$ \\
\hline Remove Wanapum Dam & None identified. & $\begin{array}{l}\text { Improves migration conditions for } \\
\text { adults and juveniles. Extends current } \\
\text { production areas for fall chinook } \\
\text { salmon. Increases juvenile survival by } \\
\text { providing increased rearing areas. } \\
\text { Improves water quality (i.e., reduced } \\
\text { temperature and dissolved gas) through } \\
\text { elimination of reservoir. }\end{array}$ \\
\hline $\begin{array}{l}\text { Remove Grand Coulee Dam and } \\
\text { Canadian storage dams }\end{array}$ & $\begin{array}{l}\text { Decreases survival of juvenile } \\
\text { salmon in mid- and lower } \\
\text { Columbia River. Reduces water } \\
\text { quality and increased downstream } \\
\text { transport of resident fish. }\end{array}$ & $\begin{array}{l}\text { Restores a natural hydrograph and } \\
\text { provides access to historic habitats. }\end{array}$ \\
\hline
\end{tabular}


Table 2.2. (contd)

\begin{tabular}{|c|c|c|}
\hline Dam Removal Options (contd) & Risks & Benefits \\
\hline Remove tributary dams & Loss of habitat for resident fish. & $\begin{array}{l}\text { Expands production areas for fall } \\
\text { chinook salmon. Reduces barriers to } \\
\text { migration by resident fish. }\end{array}$ \\
\hline Reservoir Drawdown Options & Risks & Benefits \\
\hline $\begin{array}{l}\text { Drawdown of McNary Reservoir } \\
\text { w/ bypass canal }\end{array}$ & Reduced fish passage efficiency. & $\begin{array}{l}\text { Extends current production areas of fall } \\
\text { chinook salmon. Bypass canal allows } \\
\text { continued fish transportation via } \\
\text { barges. }\end{array}$ \\
\hline $\begin{array}{l}\text { Drawdown of John Day } \\
\text { Reservoir }\end{array}$ & $\begin{array}{l}\text { Delays adult migration and } \\
\text { impacts juvenile passage. }\end{array}$ & $\begin{array}{l}\text { Expands production areas for fall } \\
\text { chinook salmon. Improves juvenile } \\
\text { salmon survival. }\end{array}$ \\
\hline Lengthen tailwater zones & $\begin{array}{l}\text { Could impact barging. Potential } \\
\text { effects on turbine efficiency and } \\
\text { juvenile mortality during } \\
\text { passage. }\end{array}$ & $\begin{array}{l}\text { Increases habitat in current tailwater } \\
\text { production areas. Improves juvenile } \\
\text { growth. }\end{array}$ \\
\hline Flow Options & Risks & Benefits \\
\hline Restore an annual hydrograph & $\begin{array}{l}\text { Decreases adult and juvenile } \\
\text { survival and increases migration } \\
\text { rate of adults in mid-to-lower } \\
\text { Columbia Rivers due to effects } \\
\text { on water quality and high flows. }\end{array}$ & $\begin{array}{l}\text { Increases production potential for fall } \\
\text { chinook salmon and steelhead. } \\
\text { Enhances juvenile growth and } \\
\text { migration rates. Increases connectivity } \\
\text { for resident and anadromous salmonids. } \\
\text { Restores natural processes and habitats. }\end{array}$ \\
\hline $\begin{array}{l}\text { Reduce hydropeaking and other } \\
\text { short-term reservoir water-level } \\
\text { manipulations. }\end{array}$ & None identified. & $\begin{array}{l}\text { Increases food-base production. } \\
\text { Increases juvenile survival and growth. } \\
\text { Restores riverine processes. }\end{array}$ \\
\hline Enhance tributary flows & $\begin{array}{l}\text { Increased connectivity might } \\
\text { result in expanded use by } \\
\text { salmonid predators. }\end{array}$ & $\begin{array}{l}\text { Increases production and juvenile } \\
\text { survival. Increases connectivity of } \\
\text { habitats for resident fishes. Improves } \\
\text { water quality and habitat. }\end{array}$ \\
\hline $\begin{array}{l}\text { Provide channel-bed-moving } \\
\text { flows for the Hanford Reach }\end{array}$ & $\begin{array}{l}\text { Could decrease adult and } \\
\text { juvenile survival and increase } \\
\text { migration rate of adults in mid- } \\
\text { to-lower Columbia Rivers due } \\
\text { to effects on water quality } \\
\text { (increased dissolved solids). }\end{array}$ & $\begin{array}{l}\text { Increases production potential for fall } \\
\text { chinook salmon and steelhead. } \\
\text { Enhances juvenile growth and migra- } \\
\text { tion rates. Increases connectivity for } \\
\text { resident and anadromous salmonids. } \\
\text { Restores natural processes and habitats. }\end{array}$ \\
\hline $\begin{array}{l}\text { Provide pulsing flows during the } \\
\text { spring }\end{array}$ & $\begin{array}{l}\text { Might increase mortality of } \\
\text { resident fish. }\end{array}$ & Might increase juvenile migration rate. \\
\hline $\begin{array}{l}\text { Restore floodplains downstream } \\
\text { of Bonneville Dam }\end{array}$ & None identified. & $\begin{array}{l}\text { Increases juvenile growth and } \\
\text { production. }\end{array}$ \\
\hline $\begin{array}{l}\text { Artificially recharge } \\
\text { groundwater from irrigation } \\
\text { return flows. }\end{array}$ & $\begin{array}{l}\text { Could decrease water quality } \\
\text { conditions. }\end{array}$ & $\begin{array}{l}\text { Increases production of anadromous } \\
\text { and resident populations via more } \\
\text { stable base flows and improved } \\
\text { temperature regimes in tributaries. }\end{array}$ \\
\hline
\end{tabular}


Table 2.2. (contd)

\begin{tabular}{|c|c|c|}
\hline Flow Options (contd) & Risks & Benefits \\
\hline $\begin{array}{l}\text { Selective water withdrawal at } \\
\text { Dworshak and Hells Canyon } \\
\text { Complex to control water } \\
\text { temperatures }\end{array}$ & $\begin{array}{l}\text { Decreases water quality (low } \\
\text { dissolved oxygen). Entrainment } \\
\text { of resident fish. }\end{array}$ & $\begin{array}{l}\text { Increases adult migration rate and } \\
\text { survival. Improves juvenile growth, } \\
\text { survival, and production. }\end{array}$ \\
\hline Engineered Options & Risks & Benefits \\
\hline $\begin{array}{l}\text { Create engineered habitats, e.g., } \\
\text { provide shoreline cover and } \\
\text { spawning gravel }\end{array}$ & Might not be achievable. & $\begin{array}{l}\text { Increases juvenile survival due to } \\
\text { decreased predation. Increases } \\
\text { spawning habitat. }\end{array}$ \\
\hline $\begin{array}{l}\text { Modify outlets at Hells Canyon } \\
\text { Complex to control water } \\
\text { temperatures }\end{array}$ & $\begin{array}{l}\text { Resident fish entrainment. Might } \\
\text { affect juvenile salmonid passage. }\end{array}$ & $\begin{array}{l}\text { Increases production through juvenile } \\
\text { growth/survival and adult survival. }\end{array}$ \\
\hline $\begin{array}{l}\text { Construct artificial river channel } \\
\text { from McNary to John Day dams } \\
\text { to provide a "riverine" } \\
\text { environment }\end{array}$ & $\begin{array}{l}\text { Might not be achievable. } \\
\text { Decreases survival of juvenile } \\
\text { salmon due to predation. }\end{array}$ & $\begin{array}{l}\text { Increases production areas for adult } \\
\text { salmon. Improves juvenile growth. }\end{array}$ \\
\hline $\begin{array}{l}\text { Rehabilitate lost habitat upstream } \\
\text { of Brownlee Dam via channel } \\
\text { modification and sediment } \\
\text { removal }\end{array}$ & $\begin{array}{l}\text { Might not be achievable. Impacts } \\
\text { secondary production. Increased } \\
\text { mortality of resident fish. }\end{array}$ & $\begin{array}{l}\text { Increases production and increased } \\
\text { juvenile survival and growth if passage } \\
\text { is provided. }\end{array}$ \\
\hline $\begin{array}{l}\text { Modify mainstem fish ladders to } \\
\text { preclude shad migration }\end{array}$ & Might affect adult migration. & $\begin{array}{l}\text { Expect improved adult migration and } \\
\text { increased juvenile survival. }\end{array}$ \\
\hline $\begin{array}{l}\text { Build pump storage for Brownlee } \\
\text { Dam }\end{array}$ & $\begin{array}{l}\text { Increases mortality of resident fish } \\
\text { through entrainment if no passage } \\
\text { is provided. Water level fluctua- } \\
\text { tions would reduce resident fish } \\
\text { production. }\end{array}$ & $\begin{array}{l}\text { Improves production and survival of } \\
\text { anadromous fish populations. }\end{array}$ \\
\hline Passage Options & Risks & Benefits \\
\hline $\begin{array}{l}\text { Provide passage at Hells Canyon } \\
\text { Complex }\end{array}$ & $\begin{array}{l}\text { Trap and haul activities might } \\
\text { decrease survival and production } \\
\text { of juvenile anadromous and } \\
\text { resident fish. }\end{array}$ & $\begin{array}{l}\text { Expands geographic range of } \\
\text { anadromous fish. }\end{array}$ \\
\hline $\begin{array}{l}\text { Provide passage at Chief Joseph } \\
\text { and Grand Coulee dams }\end{array}$ & $\begin{array}{l}\text { Decreases juvenile survival and } \\
\text { production of anadromous fish } \\
\text { populations. Genetic interactions } \\
\text { and disease might affect resident } \\
\text { fish. }\end{array}$ & $\begin{array}{l}\text { Expands geographic range of } \\
\text { anadromous fish. }\end{array}$ \\
\hline Other Options & Risks & Benefits \\
\hline Restrict harvest & $\begin{array}{l}\text { Does not restore mainstem } \\
\text { riverine habitats or processes. }\end{array}$ & Increases escapement. \\
\hline
\end{tabular}


Table 2.2. (contd)

\begin{tabular}{|l|l|l|}
\hline \multicolumn{1}{|c|}{ Other Options (contd) } & \multicolumn{1}{|c|}{ Risks } & \multicolumn{1}{c|}{ Benefits } \\
\hline Establish wild fish basins & $\begin{array}{l}\text { Does not restore mainstem } \\
\text { riverine habitats or processes. }\end{array}$ & $\begin{array}{l}\text { May result in increased fitness. May } \\
\text { reduce interactions between hatchery } \\
\text { and wild fish, including genetic } \\
\text { swamping and disease transmission. }\end{array}$ \\
\hline $\begin{array}{l}\text { Reduce abundance of non-native } \\
\text { species system-wide }\end{array}$ & $\begin{array}{l}\text { Reduction goals for some species } \\
\text { might not be achievable. Does not } \\
\text { restore mainstem riverine habitats } \\
\text { or processes. }\end{array}$ & $\begin{array}{l}\text { Improves adult passage. Increases } \\
\text { juvenile survival and growth through } \\
\text { less predation/competition. }\end{array}$ \\
\hline $\begin{array}{l}\text { (a) Depending on the species and site-specific issues, this could be a risk or benefit to juvenile salmonid } \\
\text { survival (e.g., fall chinook salmon appear to benefit from transportation while other species do not). }\end{array}$ \\
\hline
\end{tabular}

\subsection{EVALUATION CRITERIA}

After identifying the risks and benefits associated with various mainstem habitat restoration options, participants were asked to consider what criteria could be used as a measure of whether an implemented action actually resulted in restoration of riverine habitat. A list of criteria or attributes of an alluvial river system, developed before the workshop, was presented to participants for their consideration (Table 2.3) and the ecological significance or importance of these criteria to salmon production were presented for discussion. The initial response of workshop participants was that these criteria were useful, but that other criteria, specifically biotic processes, needed to be considered if we wanted to increase production of salmon in mainstem habitats. Participants added the following two criteria to the list in Table 2.3) maintenance of key trophic or community relationships, and 2) maintenance of appropriate water quality and temperature. The connection between temperature and flow regimes was brought up as an important criterion for maintaining salmon populations. Spatial connectivity or continuity of conditions was another important criterion. For example, you can't provide a normative hydrograph in one area and expect measurable improvements in population response throughout the watershed.

The primary purpose of having criteria was to give participants a defined basis for reviewing and ranking the relative value or benefits of each restoration option. That is, we asked participants to review the potential for each option to result in habitat characteristics or attributes provided in Table 2.3. If so, the option would be consistent with our goal of restoring riverine habitats and processes. Some attributes (e.g., diverse riparian plant community) might be less important in large systems like the Columbia and Snake rivers, while other attributes might need to be added to the list.

There was additional discussion of the spatial and temporal linkage between where and when adults spawn and when juveniles emerge and emigrate from the spawning areas to rearing areas. These spatial and temporal linkages were described as "windows of opportunity" in which fish select locations and time for spawning to optimize the environmental conditions that would be present when their offspring are present in the river. The participants wondered whether it would be possible to develop a subset of 
Table 2.3. Attributes of an Alluvial River System (compiled from several sources, primarily the Trinity River Restoration Program [Hoopa Valley Tribe 1997])

\begin{tabular}{|c|c|c|}
\hline Attribute & Description & Ecological Significance \\
\hline $\begin{array}{l}\text { Spatially complex } \\
\text { channel morphology }\end{array}$ & $\begin{array}{l}\text { Alternate bar mor- } \\
\text { phology, side channels } \\
\text { and backwater areas, } \\
\text { asymmetrical cross } \\
\text { sections, etc. }\end{array}$ & $\begin{array}{l}\text { Provides diverse salmonid habitat availability for all } \\
\text { life stages over wide-ranging flows. } \\
\text { - Supports diverse and productive biological } \\
\text { communities. } \\
\text { - Develops and maintains diverse riparian plant com- } \\
\text { munities in all stages of successional development. }\end{array}$ \\
\hline $\begin{array}{l}\text { Natural variability in } \\
\text { flows and water quality }\end{array}$ & $\begin{array}{l}\text { Natural periodicity, dura- } \\
\text { tion, and seasonal timing } \\
\text { of baseflows, spring/ } \\
\text { summer runoff, and } \\
\text { winter floods. }\end{array}$ & $\begin{array}{l}\text { - Inundates bar features during dispersion of riparian } \\
\text { plant seeds; discourages germination on bars. } \\
\text { - Creates variable water depths and velocities over } \\
\text { spawning gravels during salmonid spawning; } \\
\text { spatially distributes redds. } \\
\text { - Inundates alternate bar margins, including backwater } \\
\text { scour channels; creates shallow slack water areas } \\
\text { between late-winter and snowmelt periods for early } \\
\text { life stages of salmonids and amphibians. } \\
\text { - Provides favorable ranges of baseflows for main- } \\
\text { taining high-quality juvenile salmonid rearing and } \\
\text { macroinvertebrate habitat within an alternate bar } \\
\text { morphology. } \\
\text { - Provides late-spring outmigrant stimulus flows. } \\
\text { - In general, optimizes salmonid physical habitat } \\
\text { availability for all seasons. } \\
\text { - In general, restores groundwater/surface water } \\
\text { dynamics and maintains hyporheic habitats. } \\
\text { - In general, restores floodplain/riparian processes } \\
\text { associated with a snowmelt hydrograph. }\end{array}$ \\
\hline $\begin{array}{l}\text { Frequently mobilized } \\
\text { channelbed surface }\end{array}$ & $\begin{array}{l}\text { Coarse sediment surfaces } \\
\text { are mobilized by the } \\
\text { bankfull discharge, which } \\
\text { on average occurs every } \\
1 \text { to } 2 \text { years. }\end{array}$ & $\begin{array}{l}\text { - Reduces substrate embeddedness in riffle/run } \\
\text { habitats; increases survival of eggs and emerging } \\
\text { alevins. } \\
\text { - Scours and reduces sand storage in pools; creates } \\
\text { greater pool depths/volumes for adult fish cover and } \\
\text { holding. } \\
\text { - Provides turnover of spawning gravel deposits and } \\
\text { mobilizes those deposits several layers deep. } \\
\text { - Provides greater substrate complexity in riffle and run } \\
\text { habitats for improved macroinvertebrate production. } \\
\text { - Decreases riparian encroachment by scouring } \\
\text { seedlings on bars. } \\
\text { - In general, increases micro-habitat complexity. }\end{array}$ \\
\hline
\end{tabular}


Table 2.3. (contd)

\begin{tabular}{|c|c|c|}
\hline Attribute & Description & Ecological Significance \\
\hline $\begin{array}{l}\text { Periodic channelbed } \\
\text { scour and fill }\end{array}$ & $\begin{array}{l}\text { Channelbed and bars are } \\
\text { scoured deeper than the } \\
\text { coarse surface layer by } \\
\text { floods exceeding 3- to } \\
\text { 5-year annual maximum } \\
\text { flood recurrences. }\end{array}$ & $\begin{array}{l}\text { - Scours below-bed surface layer; rejuvenates spawn- } \\
\text { ing gravel deposits. } \\
\text { - Facilitates bar evolution (e.g., alternate, medial), } \\
\text { improving channelwide spawning and rearing habitat } \\
\text { complexity. } \\
\text { - Maintains and/or improves pool depths for adult } \\
\text { salmonid cover and holding. } \\
\text { - Increases diversity of surface particle size } \\
\text { distributions. } \\
\text { - Removes vegetation from bar surfaces, discouraging } \\
\text { riparian plant encroachment and bank accretion. } \\
\text { - Deposits fine sediment onto upper alternate bar and } \\
\text { floodplain surfaces, thereby reestablishing dynamic } \\
\text { riparian stands of vegetation in various stages of } \\
\text { succession. }\end{array}$ \\
\hline $\begin{array}{l}\text { Periodic channel } \\
\text { migration }\end{array}$ & $\begin{array}{l}\text { 'Typical' bank erosion } \\
\text { rates, floodplain deposi- } \\
\text { tion every } 3 \text { to } 5 \text { years, } \\
\text { and channel avulsions } \\
\text { every } 10 \text { years on } \\
\text { average. }\end{array}$ & $\begin{array}{l}\text { - Creates diverse age class structure of woody riparian } \\
\text { vegetation, producing and maintaining early- } \\
\text { successional riparian communities. } \\
\text { - Increases woody riparian overstory and understory } \\
\text { species diversity. } \\
\text { - Increases habitat quality and quantity for native } \\
\text { vertebrate species dependent on early successional } \\
\text { riparian stands. } \\
\text { - Produces high flow refuge and summer thermal } \\
\text { refuge for amphibians and juvenile fish provided in } \\
\text { rejuvenated scour channels. } \\
\text { - Improves salmonid habitat complexity through } \\
\text { creation of sloughs and side channels. } \\
\text { - Increases micro-habitat complexity from input of } \\
\text { large woody debris caused by bank erosion. }\end{array}$ \\
\hline $\begin{array}{l}\text { Balanced fine and coarse } \\
\text { sediment budgets }\end{array}$ & $\begin{array}{l}\text { Fine and coarse sediments } \\
\text { are exported at rates } \\
\text { approximately equal to } \\
\text { sediment inputs. Channel } \\
\text { morphology is maintained } \\
\text { in 'dynamic quasi- } \\
\text { equilibrium'. }\end{array}$ & $\begin{array}{l}\text { - Reduces fine sediment storage and maintains coarse } \\
\text { sediment storage; improves spawning habitat quality } \\
\text { without reducing quantity. } \\
\text { - Mobilizes coarse sediments and prevents mainstem } \\
\text { accumulation of fine sediments; increases pool depths } \\
\text { for adult salmonid cover and holding, and improves } \\
\text { physical complexity through bar evolution. } \\
\text { - Reduces fine sediment storage in banks; lessens bank } \\
\text { accretion, thereby allowing continual evolution of } \\
\text { channel morphology. } \\
\text { - Discourages bed elevation aggradation at tributary } \\
\text { deltas; maintains salmonid migration corridors. }\end{array}$ \\
\hline
\end{tabular}


Table 2.3. (contd)

\begin{tabular}{|c|c|c|}
\hline Attribute & Description & Ecological Significance \\
\hline Functional floodplain & $\begin{array}{l}\text { Areas where fine sedi- } \\
\text { ments can be removed } \\
\text { from the inner channel } \\
\text { and deposited. }\end{array}$ & $\begin{array}{l}\text { - Through scour and deposition, floodplain construc- } \\
\text { tion rates roughly equal floodplain loss as channel } \\
\text { migrates. } \\
\text { - Provides sufficient channel confinement such that } \\
\text { hydraulic processes can be maintained. } \\
\text { - Increases hydraulic roughness and allows greater } \\
\text { flow storage during high magnitude floods. } \\
\text { - Maintains riparian vegetation dynamics, such as } \\
\text { varying stages of successional development. }\end{array}$ \\
\hline $\begin{array}{l}\text { Infrequent channel } \\
\text { resetting floods }\end{array}$ & $\begin{array}{l}\text { Those that exceed the } \\
10 \text { - to } 20 \text {-year annual } \\
\text { maximum flood } \\
\text { recurrence. }\end{array}$ & $\begin{array}{l}\text { - Improves salmonid habitat complexity and quantity } \\
\text { through deep scour of channel features, significant } \\
\text { channel migration, and avulsion (creating sloughs and } \\
\text { side channels), and alternate bar scour and } \\
\text { redeposition. } \\
\text { - Maintains riparian vegetation dynamics, such as } \\
\text { varying stages of successional development } \\
\text { - Disturbs bar surfaces close to channel center to } \\
\text { discourage riparian encroachment. } \\
\text { - Provides habitat for riparian-dependent amphibian, } \\
\text { avian, and mammalian species. } \\
\text { - Improves bedload routing by minimizing impedance } \\
\text { of bedload transport past tributary deltas. }\end{array}$ \\
\hline $\begin{array}{l}\text { Self-sustaining diverse } \\
\text { riparian plant } \\
\text { communities }\end{array}$ & $\begin{array}{l}\text { Successional stages and } \\
\text { species composition } \\
\text { similar to other regional } \\
\text { unregulated river } \\
\text { corridors. }\end{array}$ & $\begin{array}{l}\text { - Increases species diversity and age class diversity. } \\
\text { - Increases riparian habitat complexity. } \\
\text { - Allows rehabilitation of evolving channel features } \\
\text { (e.g., alternate bars, sloughs). } \\
\text { - Creates vigorous woody riparian corridor that mode- } \\
\text { rates physical effects of extreme floods. } \\
\text { - Increases availability of habitat for riparian- } \\
\text { dependent amphibian, avian, and mammalian species. } \\
\text { - Moderates water temperatures at the micro-habitat } \\
\text { scale. }\end{array}$ \\
\hline $\begin{array}{l}\text { Interstitial flow pathways } \\
\text { and ground water/surface } \\
\text { water interactions }\end{array}$ & $\begin{array}{l}\text { Hyporheic habitats form } \\
\text { because of interstitial } \\
\text { pathways between surface } \\
\text { water and ground water. } \\
\text { Hydrology of floodplains, } \\
\text { terraces, sloughs, and } \\
\text { adjacent wetlands } \\
\text { fluctuate in response to } \\
\text { natural hydrograph of } \\
\text { river corridor. }\end{array}$ & $\begin{array}{l}\text { - Maintains off-channel habitats, including overflow } \\
\text { channels, oxbow channels, and floodplain wetlands. } \\
\text { - Promotes diversity of habitat types within entire river } \\
\text { corridor. } \\
\text { - Forms and maintains hyporheic habitats that diversify } \\
\text { salmonid spawning and rearing habitat (e.g., } \\
\text { increased interstitial flow through redds, temperature } \\
\text { refugia, water quality control, etc.). }\end{array}$ \\
\hline
\end{tabular}


attributes to explain how to link the attributes in Table 2.3 with life history requirements. This was noted as an interesting way to evaluate restoration options, but participants agreed it was beyond the scope of the workshop.

\subsection{PRIORITIZATION OF MAIN OPTIONS}

After discussing the criteria, participants were asked to 1) select one or any combination of restoration options for implementation, 2) evaluate its potential for successfully restoring mainstem habitat using the evaluation criteria, and 3) defend their choice to all other workshop participants (see Appendix C).

Following extensive discussion and spirited debate on whether participant choices were actually based on the agreed-upon selection criteria, each person voted on the initial list of 30 options for restoring mainstem habitats. Table 2.4 lists the top six options selected by workshop participants and the options' associated uncertainties. The first three options selected were to: 1) conduct a phased drawdown of McNary Reservoir, 2) restore an annual hydrograph, and 3) breach the four lower Snake River dams. These options captured $\sim 41 \%$ of the votes cast. The next three options selected were to breach John Day Dam, restore and manage the floodplain downstream of Bonneville Dam, and reduce the abundance of non-native fish system wide. These options captured $\sim 19 \%$ of the votes. Remaining options that received at least three votes each were to reduce hydropeaking, breach the Hells Canyon Dam, and breach Lower Granite and Little Goose dams. Clearly, the dam breaching and flow management categories were most favored by participants (each category with $32 \%$ of the total votes cast), followed by reservoir drawdown $(18 \%)$, and engineered fixes $(7 \%)$. Adult passage and "other" were the least favored categories.

\subsection{KEY UNCERTAINTIES}

During the workshop, participants raised some questions and issues related to some of the mainstem habitat restoration options. In particular, some wondered whether we could adequately define the geologic environment that salmon prefer for spawning and/or rearing. Knowing this would have assisted participants in identifying areas of the mainstem that were used historically for salmon spawning. In addition, the group wondered about the extent of our knowledge regarding the use of existing riverine areas for spawning. The workshop participants were not made aware of the analyses conducted in Chapter One of this report, which directly addresses these concerns.

Assuming that we can 1) identify areas where fall chinook salmon can spawn/incubate/rear, and 2) identify those areas that have the right attributes, but are not being used (need to determine the reasons why, i.e., passage, water quality, lack of seed populations, flow management, etc.), then we can either develop actions to get fish into suitable habitat or use restoration options to provide the attributes required by fish. It appears that most of the desired habitat is either inundated or blocked, and would require rehabilitation even if it were made available. These same habitats would probably require flow management changes to be maintained in a viable condition. Specific examples include the Snake River downstream of Lewiston and the Snake River upstream of Brownlee Dam. This approach was deemed consistent with the philosophy to "protect what you have, fix what's slightly broken, and cut losses on what is toasted." 
Table 2.4. Top Six Mainstem Habitat Restoration Options Selected by Workshop Participants and a Summary of Associated Uncertainties

\begin{tabular}{|c|c|}
\hline Option & Uncertainties \\
\hline $\begin{array}{l}\text { Lower McNary Reservoir in } \\
\text { stages (experimentally then } \\
\text { permanently); partial (spill- } \\
\text { way crest) with concept to } \\
\text { reconnect Wallula Gap to } \\
\text { reuse transportation; expand } \\
\text { Hanford Reach habitat }\end{array}$ & $\begin{array}{l}\text { - How much habitat will be gained? } \\
\text { - What will be the transportation impacts? } \\
\text { - Will metapopulation expansion occur (seeding new tributaries)? } \\
\text { - What will be the impacts on non-native predators and salmonids and native } \\
\text { residents? } \\
\text { - What will be the time lag to restoration? } \\
\text { - Will chill happen in terms of sediment quality and movement? } \\
\text { - Will there be blockage to upstream tributaries (access)? }\end{array}$ \\
\hline $\begin{array}{l}\text { Restore an annual } \\
\text { hydrograph }\end{array}$ & $\begin{array}{l}\text { - Will dissolved gas levels increase, decrease or stay the same? } \\
\text { - What will be the impacts on juvenile or adult fish passage survival? } \\
\text { - Will flooding occur? } \\
\text { - Will upstream passage (adult) be delayed? How much? } \\
\text { - What will be the impacts on reservoir refill; consequences to fish and } \\
\text { - What will be the sediment transport impacts? } \\
\text { - What will be the late summer temperature effects? }\end{array}$ \\
\hline $\begin{array}{l}\text { Breach the four lower Snake } \\
\text { River dams }\end{array}$ & $\begin{array}{l}\text { - How much habitat will be available? } \\
\text { - How long will it take to use the habitat (achieve riverine processes)? } \\
\text { - What will be the impacts of sediment transport on the McNary Reservoir? } \\
\text { - What will be the time lag to restoration? } \\
\text { - What will be the impacts on non-native predators, salmonids, and resident } \\
\text { - How much blockage will there be to upstream tributaries (access)? }\end{array}$ \\
\hline Breach John Day Dam & $\begin{array}{l}\text { - How much habitat will be available? } \\
\text { - How long will it take to use the habitat (achieve riverine processes)? } \\
\text { - What will be the impacts of sediment transport on the McNary Reservoir? } \\
\text { - What will be the time lag to restoration? } \\
\text { - } \text { species? } \\
\text { - How much blockage will there be to upstream tributaries (access)? } \\
\text { - Will Snake River fish be transported? } \\
\text { - Will predators be redistributed? }\end{array}$ \\
\hline $\begin{array}{l}\text { Restore and manage } \\
\text { floodplain (below } \\
\text { Bonneville Dam) }\end{array}$ & $\begin{array}{l}\text { - What will it cost? } \\
\text { - What habitat will be gained? } \\
\text { - What land will become available to restrict and manage? } \\
\text { - What will be the species population responses (will upstream be in sync with } \\
\text { plains)? }\end{array}$ \\
\hline $\begin{array}{l}\text { Reduce abundance of non- } \\
\text { native species from mouth } \\
\text { of Columbia River to Grand } \\
\text { Coulee Dam (e.g., system- } \\
\text { wide bass, lower Columbia } \\
\text { River shad) }\end{array}$ & $\begin{array}{l}\text { - Is it doable? } \\
\text { - Is it sustainable? } \\
\text { - Is it demonstrable? } \\
\text { - Will there be new invasions? } \\
\text { - How will native predators be affected and respond? } \\
\text { - How will species respond to other habitat restoration options? }\end{array}$ \\
\hline
\end{tabular}


Another issue that was discussed was whether habitats could be engineered to meet ecological requirements for fish at the site level with and without major modifications to existing systems. This might serve as a more reasonable alternative (from an economic and social standpoint) to dam removals and drawdowns. Examples might include tributary restoration, providing return flows from irrigation, creating better rearing habitats.

One of the most conspicuous trade-offs associated with mainstem habitat options for salmon restoration centered around the transportation or barging of juvenile salmon. Concerns were expressed regarding potential impacts of drawdowns and dam removal on the current transportation program. For example, what are the survival trade-offs between transportation and in-river travel? Which populations would be most affected, and how would this affect the geographic focus of mainstem habitat restoration options?

Finally, there was concern that workshop participants had focused our discussion on "parts" or a series of single options. One suggestion was that we should not only prioritize the "best" option, but also the best set of combined options.

\subsection{SUMMARY}

The stated goal of the workshop was to provide options for restoring riverine processes within the mainstem Columbia and Snake rivers. To that end, we identified about 30 possible actions (and combinations of actions) that could be undertaken to enhance, restore, or replace riverine processes and habitats. A key assumption is that if normative riverine processes are restored, the habitat within which salmon and steelhead evolved will be restored, and populations will respond positively. However, it is important to note that some restoration options selected as a priority by workshop participants did not necessarily restore mainstem riverine processes. Additionally, there was not total agreement among participants on the sequence of priorities, even though there was a group "trend" that favored some actions (e.g., drawdown of McNary Reservoir) over others. Participants in this workshop initially mostly focused on "parts" or single options for restoring mainstem habitats of anadromous salmonids. Changes in the hydrograph, reservoir drawdown, and dam breaching (12 different projects were mentioned) took up most of the discussion. Most participants felt that one or more hydroelectric projects would need to be breached, or a reservoir would need to be drawn down. These actions would have to be implemented in combination with providing a more normative hydrograph (through manipulation of upstream storage reservoirs).

Some participants argued that restoring the abiotic environment was one aspect of salmon recovery and that certain biotic factors also needed to be considered. For example, management of non-native animal and plant species was considered to be critical to restoring mainstem salmon and steelhead populations.

The actual condition of "restored" habitats is a major uncertainty for all proposed options. For example, to what extent would groundwater/surface water dynamics and hyporheic habitats be functional? Even if physical habitat were restored in the mainstem by an action such as reservoir drawdown, would the hydropower system be operated to resemble a natural hydrograph so that essential components 
of life history strategies could be completed? If not, gains derived from the reservoir drawdown could be negated by short-term fluctuating water levels. Additionally, some participants correctly pointed out that the performance of salmon relative to a change in physical habitat features, whether it be through reservoir drawdown or altered hydrological conditions, would be different now than during the period before the development of the hydroelectric system, because biotic conditions (e.g., secondary production, predator assemblages, floodplain connections, etc) have been changed.

Ensuring that connections between temperature and flow regimes are maintained or enhanced would be a key requirement of any restored habitat. Maintaining these conditions over the appropriate time period (temporal connectivity) and throughout the system (spatial connectivity) are also important. For example, providing a normative hydrograph in one part of the river system for spawning may not provide conditions required for rearing in another part of the river and at another point in time. The hydrograph is the single most important important controlling variable because it affects water quality (including dissolved gas), nutrient flow, and temperature.

Although both the geomorphologic and hydrologic aspects of the Columbia and Snake rivers will ultimately "control" the time required for restoration of riverine processes, there are a number of socioeconomic issues that will ultimately affect the actual timing of restoration. Socioeconomic and political aspects of the proposed actions were not factored into our discussions, but will likely "drive" the decisions that result in the implementation of any options for restoring mainstem habitats and riverine processes. These decisions must incorporate knowledge of existing geomorphological templates, hydrological processes, and life history options for both juvenile and adult salmonids. These variables, acting in consort, are necessary to restore the riverine processes that fall chinook salmon and other salmonids in the mainstem Columbia and Snake rivers require for successful spawning, incubation, and rearing. 


\section{CHAPTER THREE TESTS OF TWO RESTORATION STRATEGIES}

Based on knowledge of available data and the workshop results summarized in Chapter Two, the Battelle/USGS study team decided to conduct more detailed analyses of two strategy tests or options for restoring mainstem habitats and riverine processes: 1) drawdown of John Day reservoir, and a natural river drawdown of lower Snake River dams. The USGS team led the first analysis, building on previous work conducted by Sheer (1999). The Battelle team led the second analysis, using the extensive data base summarized in Hanrahan et al. (1998). The implications of different flow regimes or changes to the current hydrograph are discussed for both of these strategy tests.

\section{DRAWDOWN OF JOHN DAY RESERVOIR}

\subsection{INTRODUCTION}

This analysis considered possible measures to restore mainstem riverine habitats in the John Day reservoir on the Columbia River. John Day reservoir was created in 1968 with the construction of John Day Dam and is the longest reservoir $(122.2 \mathrm{~km})$ in the lower Columbia River. It is also is the most downstream reservoir in the system with significant flood storage capabilities. Before impoundment, this stretch of river supported significant fall chinook salmon (Oncorhynchus tschawytscha) spawning (estimated at close to 34,000 adults; USAEC 1951) and functioned as a migration and rearing corridor for juvenile salmonids (Fulton 1968). Currently, John Day reservoir functions primarily as a migration and rearing corridor for juvenile salmonids and a migration corridor for adult salmonids.

The objective of this analysis was to evaluate if physical habitat for spawning and rearing of fall chinook salmon could be restored in the John Day reservoir. Our analysis included characterizing the physical features of the reservoir under three operational scenarios: normal pool levels, spillway crest drawdown, and full drawdown or natural river channel. These features were then modeled under varying hydraulic conditions to determine the potential spatial distribution and extent of fall chinook spawning and rearing areas. The following sections review physical habitat characteristics used by fall chinook salmon, describe methods we used to estimate potential habitat, provide results of our analysis, and describe implications of the results to habitat restoration objectives.

\subsection{PHYSICAL HABITAT REQUIREMENTS}

\subsubsection{FALL CHINOOK SALMON SPAWNING}

Many environmental factors influence the selection and success of fall chinook salmon spawning, including water depth, lateral bed channel slope, gradient, water temperature, substrate—grain size of bed material or sediments—water velocity, and scour effects (Burner 1951; Vronskiy 1972; Chapman et al. 
1986; Chapman 1943; Conner et al. 1994). Measurements of redd locations in the Hanford Reach of the Columbia River showed that fall chinook salmon used spawning substrates ranging from 5 to $30 \mathrm{~cm}$ in diameter, with water depths from 0.3 to $9.0 \mathrm{~m}$, and water velocities from 0.4 to $2.0 \mathrm{~m} / \mathrm{sec}$ (Swan et al. 1988; Swan 1989; Chapman et. al. 1983). Fall chinook salmon redds in the Columbia and Snake rivers are also commonly associated with lateral slopes ranging from 0 to 5\% (Geist 1998; Conner et al. 1994).

Large-scale geomorphic features of rivers also can influence spawning locations. For example, Dauble and Watson (1990) found that redd locations in the Hanford Reach of the Columbia River were common in areas with complex channel patterns. Redds have also been found to occur in transition areas between pools and riffles (Bjornn and Reiser 1991) and at the heads of riffles, preceding the crests of rapids in areas of high subgravel flow (Vronskiy 1972). There is also some evidence that clustering of redds may be related to physical conditions associated with the hyporheic zones or areas where groundwater downwelling or upwelling occurs. These areas occur more commonly in river reaches with complex channel patterns (Brunke and Gonser 1997) and may be selected by adults for spawning because of the increased water flow and consequent high oxygenation through the bed materials (Iwamoto et al. 1978; Geist and Dauble 1998).

\subsubsection{FALL CHINOOK SALMON REARING}

After hatching in the spring, fall chinook salmon emerge from the gravel, rear in rivers and streams for 2 to 3 months, then migrate to the ocean during their first summer of life as subyearlings (Taylor 1990; Healey 1991). Subyearling fall chinook salmon rear mainly in shoreline areas within lotic habitats of the Snake and Columbia rivers (Mains and Smith 1964; Becker 1973; Dauble et al. 1980; Dauble et al. 1989), as well as in reservoirs downstream of spawning areas (Zimmerman and Rasmussen 1981; Bennett et al. 1990, 1991, 1993). Three physical factors influencing their shoreline orientation include depthgradient, velocity, and substrate. For example, Bennett et al. (1993) reported that areas with gentle sloping gradients were characteristic of rearing areas in Little Goose Reservoir. Key et al. (1996) found highest densities of subyearling fall chinook salmon in gradients of 35 to $40 \%$. Dauble et al. (1989) also noted that subyearling fall chinook preferred shoreline areas.

Several studies have shown that subyearling fall chinook salmon have an affinity for areas with low water velocity. Key et al. (1996) found the greatest number of fall chinook salmon in areas with velocities $\sim 0.2 \mathrm{~m} / \mathrm{s}$ on the Hanford Reach. Similarly, velocities of $0.35 \mathrm{~m} / \mathrm{s}$, or less, were important to fall chinook salmon that reared in the Hells Canyon Reach area of the Snake River (Garland and Tiffan, USGS, unpublished data).

Substrate type appears to be a less important habitat variable for rearing than are depth and velocity if the substrate is smaller than $250 \mathrm{~mm}$. Key et al. (1994a, 1994b) reported that subyearling chinook salmon occurred over substrates ranging from sand to cobble/boulder in both the free-flowing Snake and the Hanford Reach. In contrast, Curet (1993) and Bennett et al. (1993) reported that subyearling chinook salmon that reared in Lower Granite and Little Goose reservoirs preferred sandy areas. However, large substrates over $250 \mathrm{~mm}$ in size that are concentrated along shorelines, such as riprap, are avoided by subyearling chinook salmon and do not provide suitable rearing habitat (Garland et al. [In review]). 


\subsection{METHODS}

Normal operating pool, spillway crest, and natural river (full drawdown) levels were simulated at John Day Dam for three discharges: 100, 156, and $300 \mathrm{kcfs}$. Based on preliminary modeling analysis, normal operating pool elevation was $264 \mathrm{ft}(80.5 \mathrm{~m})$ above mean sea level (MSL) for each of the three modeled discharges. Spillway crest water surface elevation ranged from 219 to $231 \mathrm{ft}$ (66.7 to $70.4 \mathrm{~m}$ ) MSL, and the water surface elevation for natural river ranged from 159 to $160 \mathrm{ft}$ ( 48.5 to $48.8 \mathrm{~m}$ ) above MSL. The bed elevation surface upon which the hydraulic simulation was based was derived from a survey conducted by the USACE, Portland District, in 1994, and was supplemented in the shoreline areas using data from the USGS 30- x 30-m resolution digital elevation models.

Mean water column velocities were estimated for John Day reservoir under steady-state flow using a two-dimensional hydraulic model. The model (River2D) applies a two-dimensional finite element method to solve the shallow water flow equations. Ghanem et al. (1995) provide a detailed explanation of the model. Values for mean column water velocity were generated by the model at nodes spaced quasiuniformly with a horizontal distance of $\sim 90 \mathrm{~m}$ between neighboring nodes. By interpolating between the nodes, velocities and water depths were calculated for all cells (10- x 10-m resolution). The final data sets were developed as ARC/INFO grids.

We used geomorphic features, velocity, and water depth to classify the reservoir-river into habitat units of pools, runs, and riffles (after Bovee 1986). Pools, runs, and riffles were identified by calculating the Froude number and equating this value to one of the three meso-habitat types. The Froude number is the dimensionless function of velocity and depth $F r=V /(g D)^{0.5}$, where $V$ is the mean water column velocity, $D$ is the water depth, and $g$ is the acceleration due to gravity. This approach has been previously used to determine habitat types in streams (Yu and Peters 1997; Jowett 1993). Classification of habitat types for John Day Reservoir was based on the following Froude number ranges in Yu and Peters (1997): Pool, $F r\langle 0.2$; Run, $0.2>=F r>=0.4$; Riffle, $F r>0.4$.

\subsubsection{FALL CHINOOK SPAWNING HABITAT MODEL}

We identified potentially suitable habitat in John Day reservoir for fall chinook salmon spawning based on a physical limitation approach. It is important to note that this technique only provides an estimate of the maximum spatial extent of wetted areas that meet some key limiting factors for fall chinook spawning. The location and amount of potentially suitable habitat under each scenario should be used as a guideline for comparisons of relative amounts; the actual extent of suitable area if substrate and small-scale hydraulic features could be incorporated in the model would be reduced. Three important factors in defining fall chinook spawning requirements (water depth, water velocity, and meso-habitat or channel morphology [river geomorphology]) were used to locate areas meeting minimum habitat requirements. All three water levels (natural river, spillway crest, normal operating pool) were modeled. The discharges used were 100 and $156 \mathrm{kcfs}$ - levels similar to those found during fall chinook spawning in the Hanford Reach (Dauble and Watson 1997).

Hydrographic survey data and existing fisheries data were compiled in digital format and used to create GIS layers representing water depth and velocity for normal operating pool and natural river 
conditions. Specific criteria (water depth and velocity) and general morphological features (pools, runs, and riffles) were used to estimate potential spawning habitat for the two discharge conditions. Habitat was classified as potentially suitable where the mean column water velocity was $\geq 0.4 \mathrm{~m} / \mathrm{s}$ and $\leq 2.0 \mathrm{~m} / \mathrm{s}$, and where the water depth was $\geq 0.3 \mathrm{~m}$ and $\leq 9.0 \mathrm{~m}$. Areas located in riffle or near-riffle boundaries (based on Froude calculations) were also considered as optimal/preferential spawning areas. A GIS analysis was then performed to estimate the extent of fall chinook salmon habitat using all data layers. Substrate characteristics were not factored into the estimates because in-channel data were not available for the entire reservoir.

\subsubsection{REARING HABITAT MODEL}

Data collected from the Hanford Reach in 1994 and 1995 (Key et al. 1996) were used to develop a predictive model of physical parameters that affect subyearling chinook salmon rearing. These data were processed into a two-dimensional spatial coverage of rearing probabilities based on habitat information in a GIS. Fish and habitat data were collected across three habitat matrices: 1) velocity $\mathrm{x}$ depth, 2) velocity $\mathrm{x}$ substrate, and 3) depth x substrate and habitat measures (e.g., water temperature, depth, cover, turbidity, distance to shore) made at each point abundance electrofishing sample sites according to Persat and Copp (1990).

Habitat and catch data from the Hanford Reach were used to create a discriminant function from which to classify fall chinook salmon use of potential rearing habitat. However, because of GIS data requirements, our analysis of John Day reservoir was limited to only three habitat variables - velocity, depth, and distance from shore. To normalize the data, velocity and depth were square root transformed, and an inverse transformation was used for distance to shore. Depths $>1.6 \mathrm{~m}$ and velocities $>1.21 \mathrm{~m} / \mathrm{sec}$ were deemed not characteristic of juvenile fall chinook rearing habitat (Key et al. 1996) and were excluded from analyses. Because the data were highly collinear, principal components analysis was used to create a new data set of uncorrelated variables. The principal components scores of habitat variables were used to create a discriminant function to distinguish between catch values. This discriminant function was subsequently used to derive the probabilities of correctly classifying juvenile fall chinook salmon presence (0 or >10 fish) in different John Day reservoir habitats (SAS 1996).

Using GIS analysis, we created 10- x 10-m habitat cells for each of the three operational scenarios and the three discharge regimes. Data from each cell were analyzed using the discriminant function to classify fish presence or absence in each cell and the probability of each classification being correct. Areas of all cells having probabilities of $>10$ fish within each probability range were summed to determine the total rearing area. We defined cells with probabilities 0.7 that 10 or more chinook salmon were present as "high probability habitat." Cells with probabilities $<0.7$ were defined as "low probability habitat." Total acres of high and low probability habitats were calculated, as well as total surface, for all scenarios and flows modeled. Longitudinal differences in the amount of rearing habitat were determined by partitioning the river into seven, 10-mile reaches. 


\subsection{RESULTS}

\subsubsection{HYDRAULIC CONDITIONS}

The total wetted area or lateral extent of the river varied, depending on the water surface being modeled. Figure 3.1 indicates the difference in spatial extent of the river for normal operating pool, spillway crest, and natural river pool levels, for a discharge of $300 \mathrm{kcfs}$. Under the normal operating pool level, the water surface from John Day Dam to McNary Dam rises less than $1.2 \mathrm{~m}$, depending on the discharge level (Figures 3.2-3.4). At a discharge of $156 \mathrm{kcfs}$, the water surface is relatively constant from rkm 346 through rkm 462, with slight changes from rkm 462 upstream to McNary Dam at rkm 470 (Figure 3.3). The water surface of spillway crest pool levels rises $4.6 \mathrm{~m}$ from dam to dam during a discharge of $156 \mathrm{kcfs}$. Under spillway crest conditions at the same discharge, backwater effects from John Day Dam decrease near rkm 423. The natural river level has a gradual gradient or water surface change of $29 \mathrm{~m}$ from the upper to lower end of the 122-km long reservoir. Information on the preimpoundment river indicates that this stretch of river was characterized by a gradient of $0.2 \mathrm{~m} / \mathrm{km}$ for non-rapids areas and drops of 0.4 to $1.5 \mathrm{~m} / \mathrm{km}$ for rapids (USACE 1951).

Water velocities are relatively constant throughout the reservoir under normal operating conditions. At a discharge of $156 \mathrm{kcfs}$, the majority of the wetted area (99.6\%) under normal operating pool has mean column water velocities $<0.9 \mathrm{~m} / \mathrm{s}$ (Figure 3.5). Eighty-four percent of the wetted area is characterized by velocities $<0.9 \mathrm{~m} / \mathrm{s}$ under the spillway crest scenario. The remaining $16 \%$ of the wetted area (located in the upper end of the reservoir between rkm 423 and 468) is characterized by water velocities between

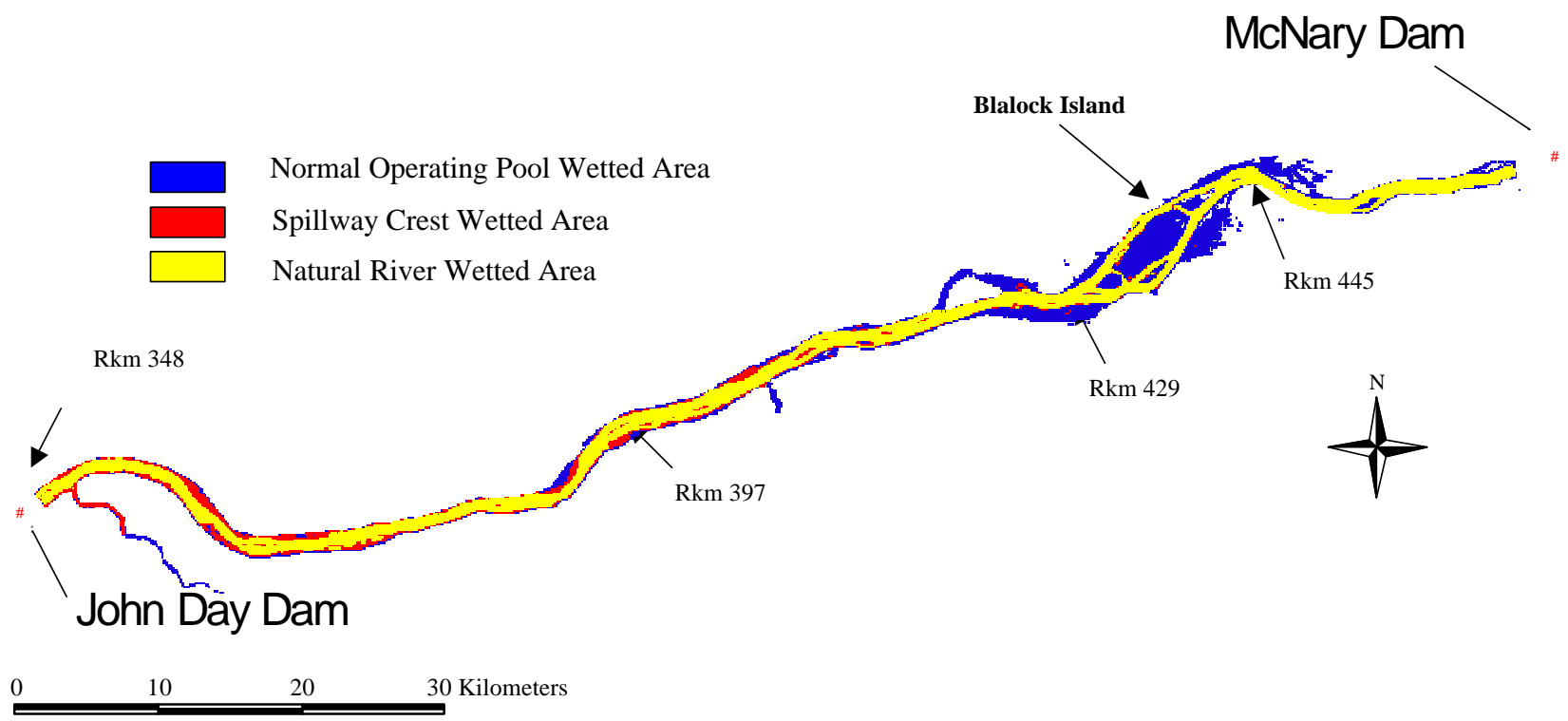

Figure 3.1. Spatial Extent of Wetted Surface Area of the Columbia River Between John Day and McNary Dams for Normal Operating Pool, Spillway Crest, and Natural River Scenarios for a Discharge of $300 \mathrm{kcfs}$ 


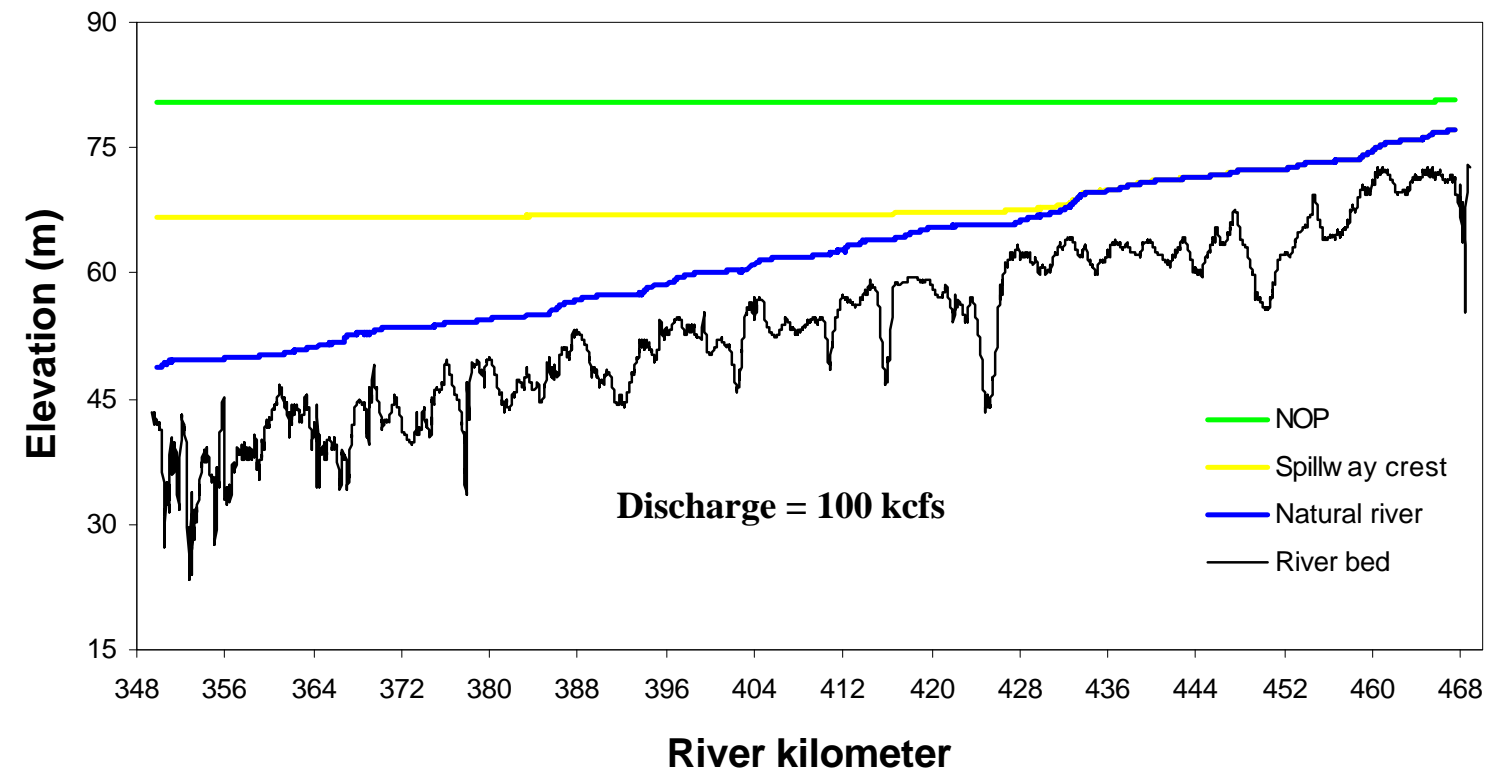

Figure 3.2. Longitudinal Profile of Water Surface Elevation for John Day Reservoir, With a River Discharge of $100 \mathrm{kcfs}$

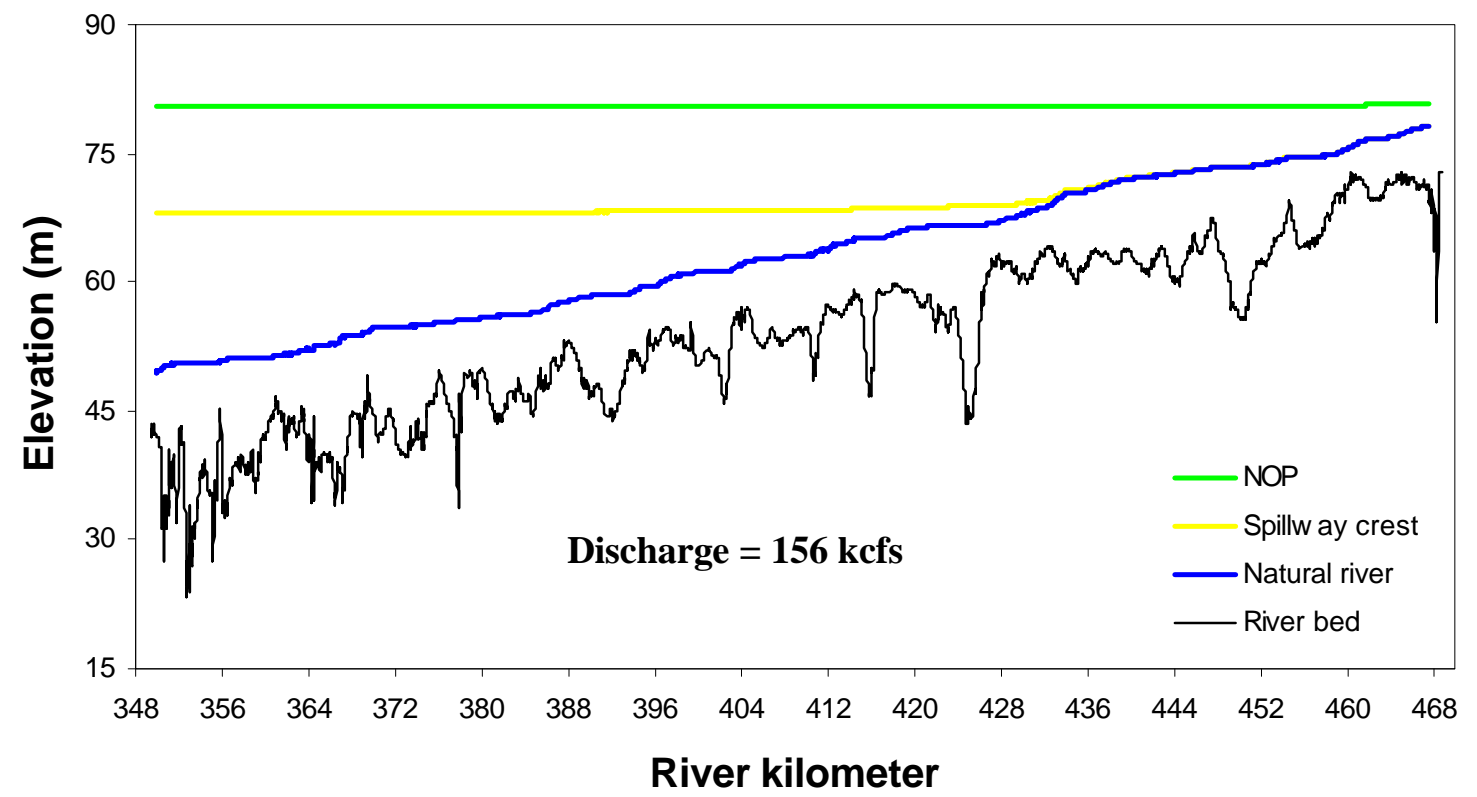

Figure 3.3. Longitudinal Profile of Water Surface Elevation for John Day Reservoir, With a River Discharge of $156 \mathrm{kcfs}$ 


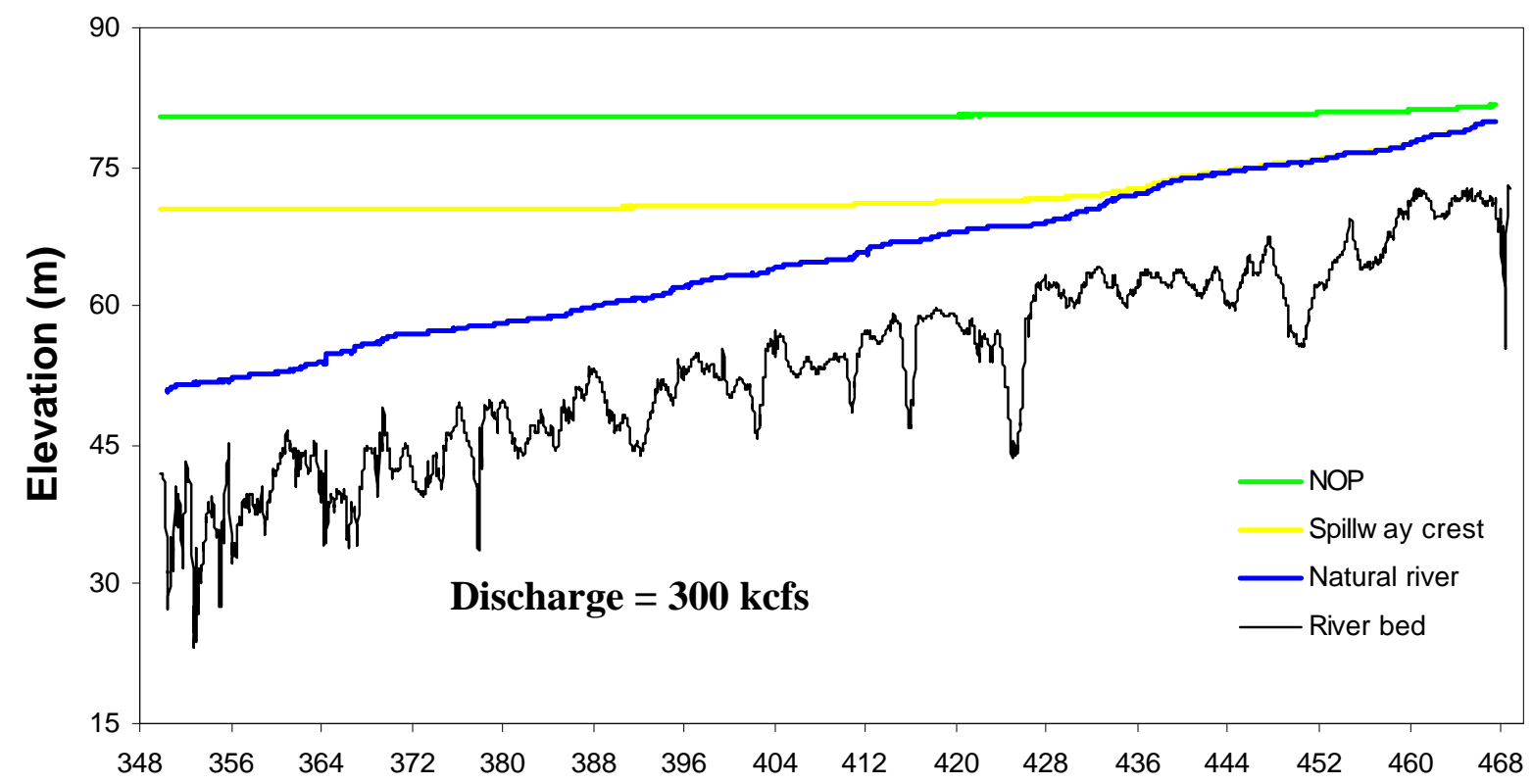

River kilometer

Figure 3.4. Longitudinal Profile of Water Surface Elevation for John Day Reservoir, With a River Discharge of $300 \mathrm{kcfs}$

0.9 and $2.4 \mathrm{~m} / \mathrm{s}$ (Figure 3.5). The natural river pool level has $49 \%$ of the wetted area characterized by velocities $<0.9 \mathrm{~m} / \mathrm{s}$, the majority of which are distributed in the lateral areas of the river channel (Figure 3.5). Twenty percent of the total area is characterized by water velocities between 1.5 and $2.4 \mathrm{~m} / \mathrm{s}$, and $29 \%$ of the wetted area has velocities between 0.9 and $1.5 \mathrm{~m} / \mathrm{s}$. These higher velocities are present, longitudinally, throughout the river.

For $156 \mathrm{kcfs}$ discharge and under normal operating conditions, the river is classified as $99.9 \%$ pool habitat (Figures 3.6, 3.7). Under the spillway crest water level scenario, the river is classified as 93\% pool and $7 \%$ run. The majority of run habitat occurs in the upper third of the reservoir (upstream of rkm 262; Figure 3.8). With drawdown to natural water levels, the river channel is classified as $76 \%$ pool habitat, 23\% run, and 1\% riffle habitat; these habitat types occur throughout the river (Figure 3.9).

\subsubsection{SPAWNING HABITAT}

The total area meeting spawning habitat criteria at the $156 \mathrm{kcfs}$ flow scenario is 607 ha (3\% of total wetted area) for the normal operating pool level, 2,650 ha (23\% of total wetted area) for spillway crest water level, and 4,600 ha (51\% of total wetted area) for the natural river level (Figures 3.10, 3.11). The amount of suitable habitat represents a liberal estimation because not all possible variables were included in the model (e.g., bed slope, bed scour, and substrate). Our estimates should be considered an indication of maximum potential spawning area; the actual spatial extent would be somewhere within the described habitat patches. For this reason, it is not appropriate to calculate relative salmon production numbers for each flow scenario. Patches suitable for spawning are distributed throughout the reservoir under natural 


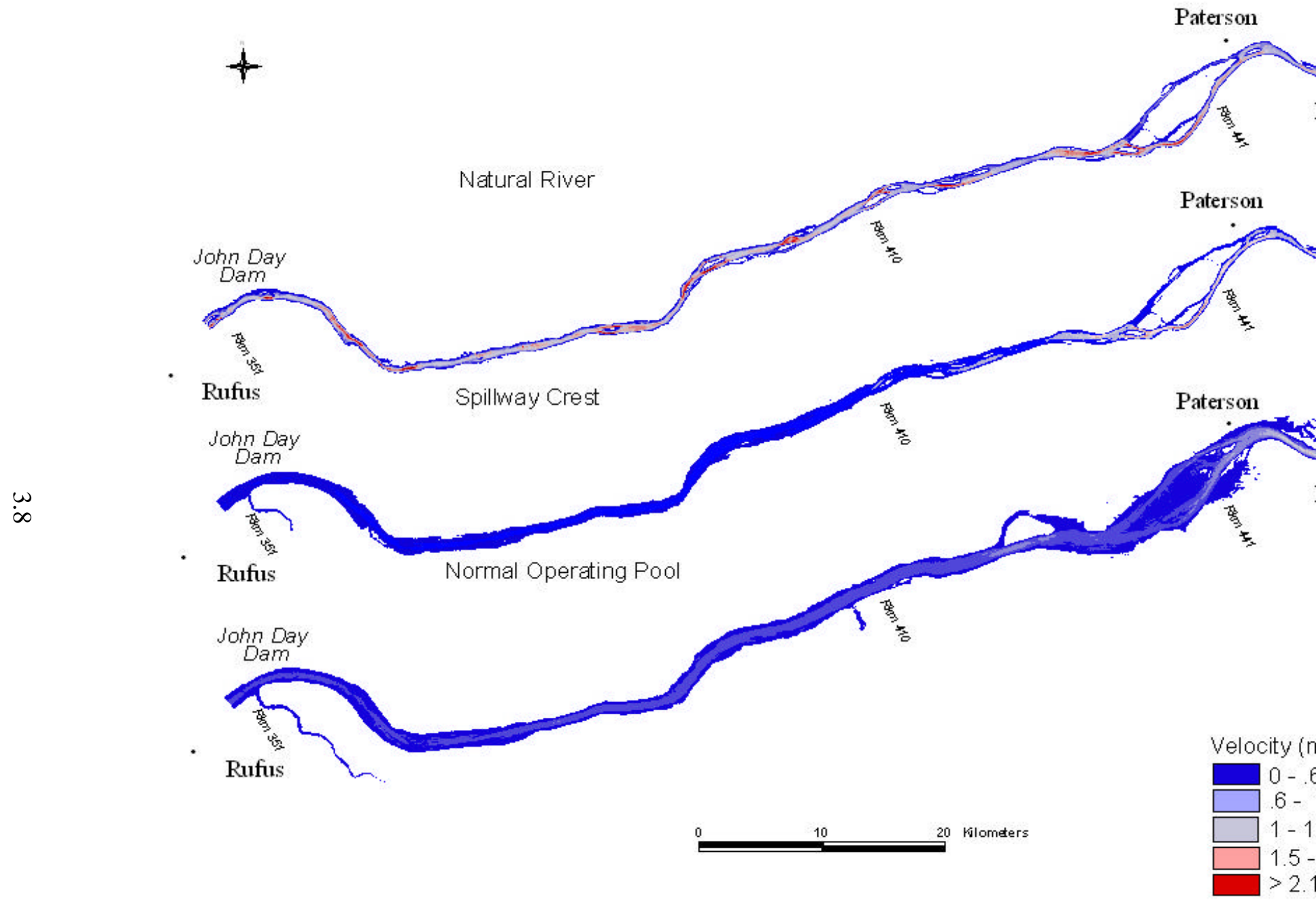

Figure 3.5. Distribution of Water Velocity (ft/s) Under Different Water Level Scenarios Based on Hydraul 
Normal Operating Pool

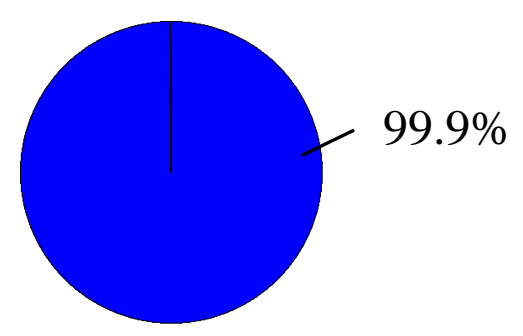

Spillway Crest

Pool

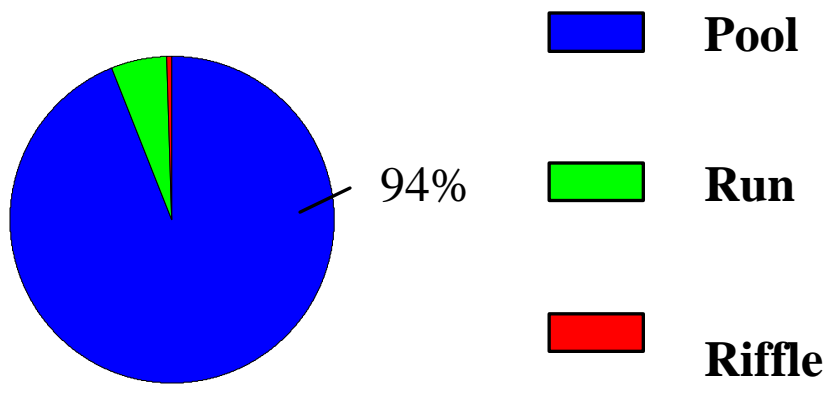

Natural River

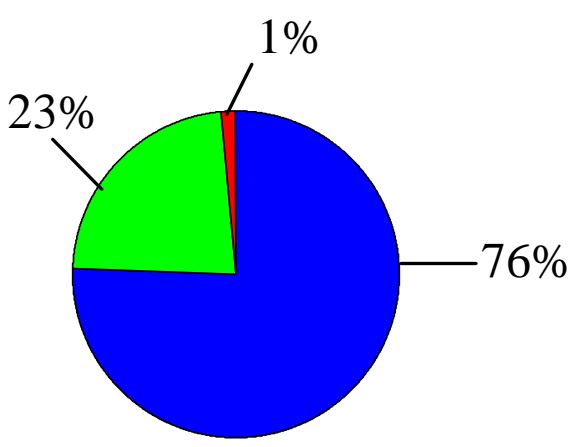

Summary of predicted meso-habitat features (in hectares)

\begin{tabular}{|l|r|r|r|}
\hline Condition & Pool (hectares) & Run (hectares) & Riffle (hectares) \\
\hline Natural $-\mathbf{1}$ & 6602 & 1521 & 145 \\
\hline Natural $-\mathbf{2}$ & 6844 & 2102 & 120 \\
\hline Spillway Crest $-\mathbf{1}$ & 10403 & 626 & 49 \\
\hline Spillway Crest $-\mathbf{2}$ & 10981 & 757 & 28 \\
\hline Normal Pool $-\mathbf{1}$ & 19808 & 0 & 0 \\
\hline Normal Pool $-\mathbf{2}$ & 19831 & 1 & 1 \\
\hline
\end{tabular}

Figure 3.6. Percent of Pool, Run, and Riffle Habitat Derived From Water Depth and Velocity. Pools, riffles, and run areas were derived from Froude number calculations. Summary table indicates the estimated total area for each habitat feature under the three operational scenarios. 


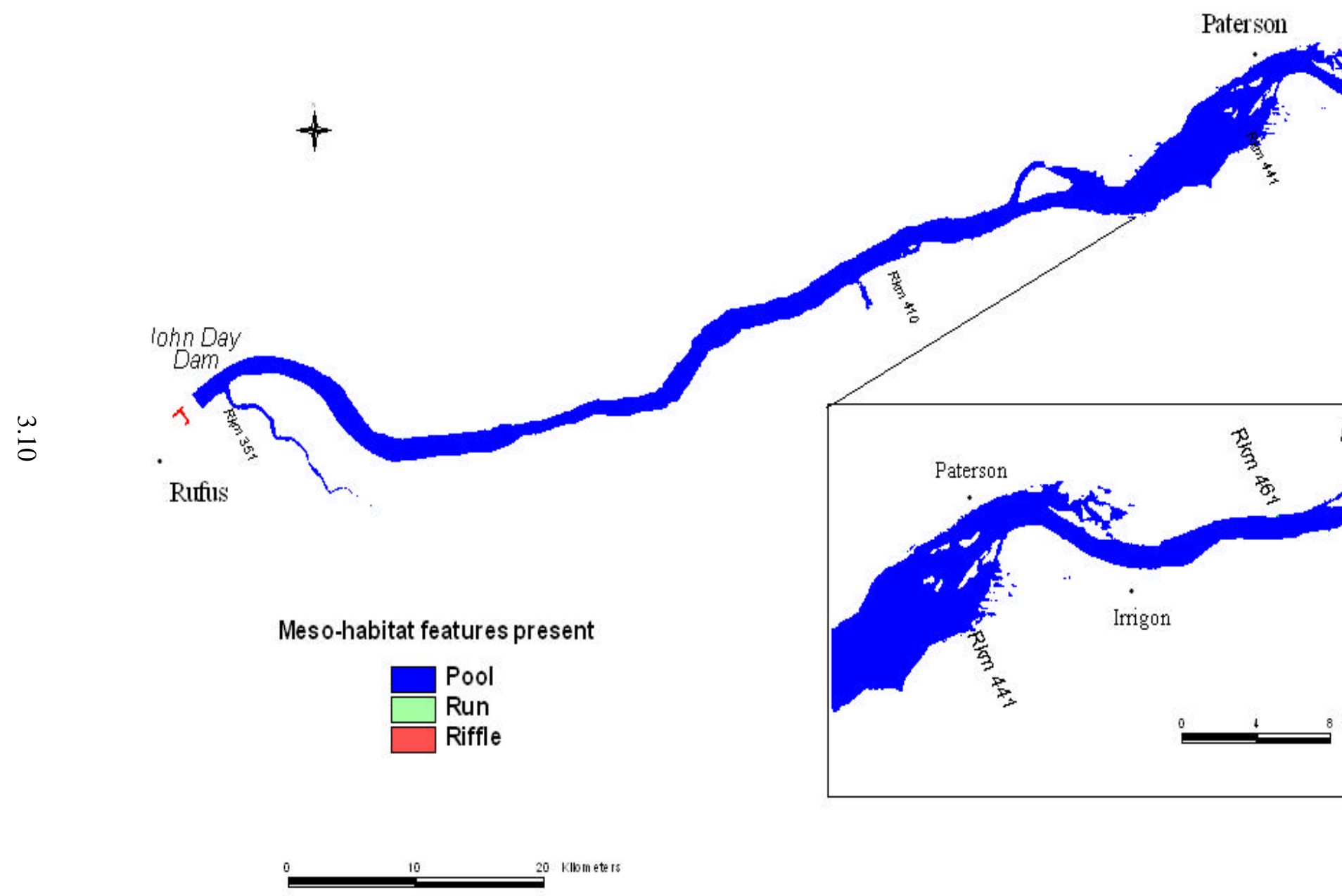

Figure 3.7. Distribution of Pools, Runs, and Riffles for Normal Operating Pool River Level (156 kcfs) Derived 


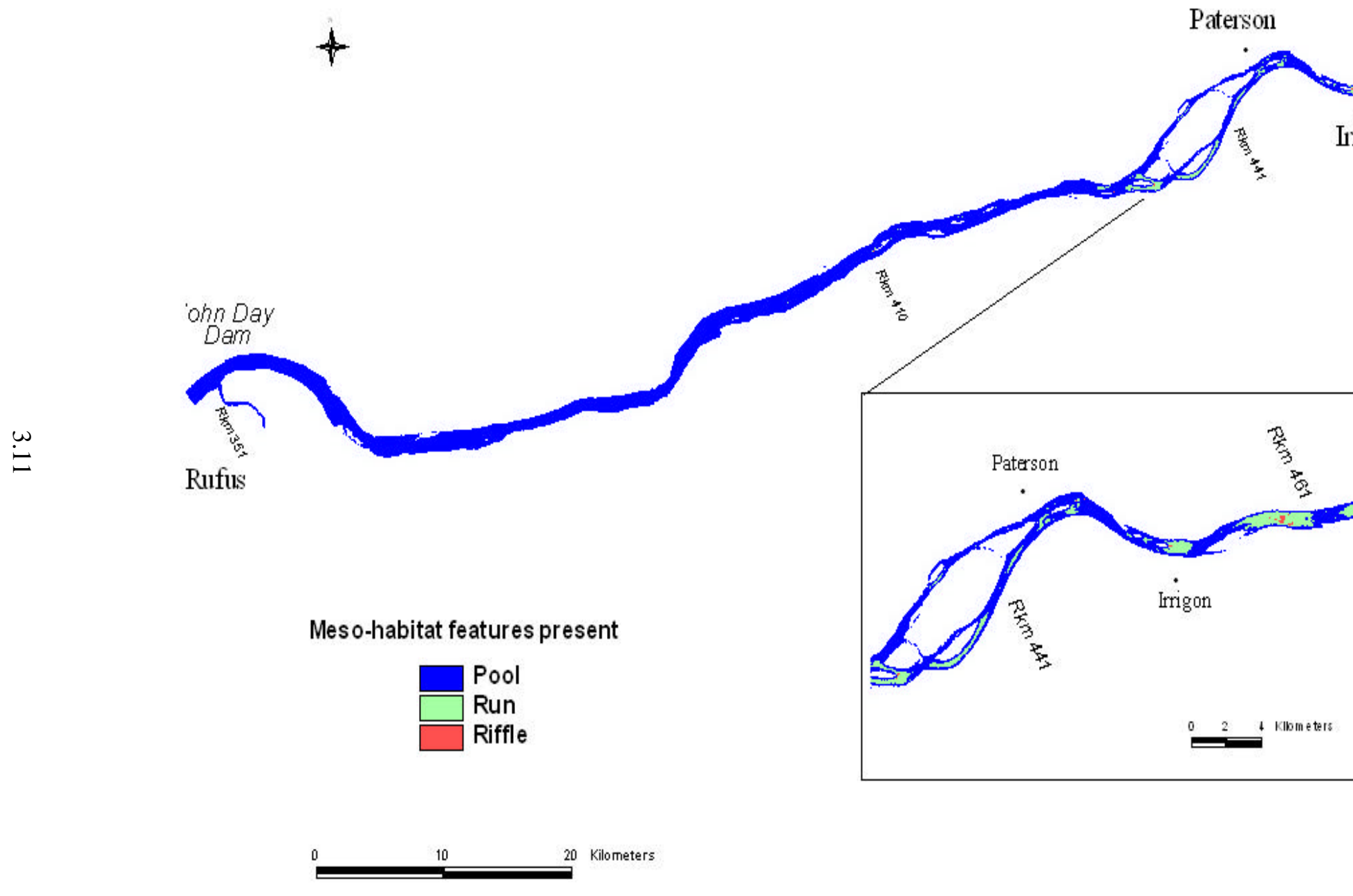

Figure 3.8. Distribution of Pools, Runs, and Riffles for Spillway Crest River Level ( $156 \mathrm{kcfs}$ ) Derived from 


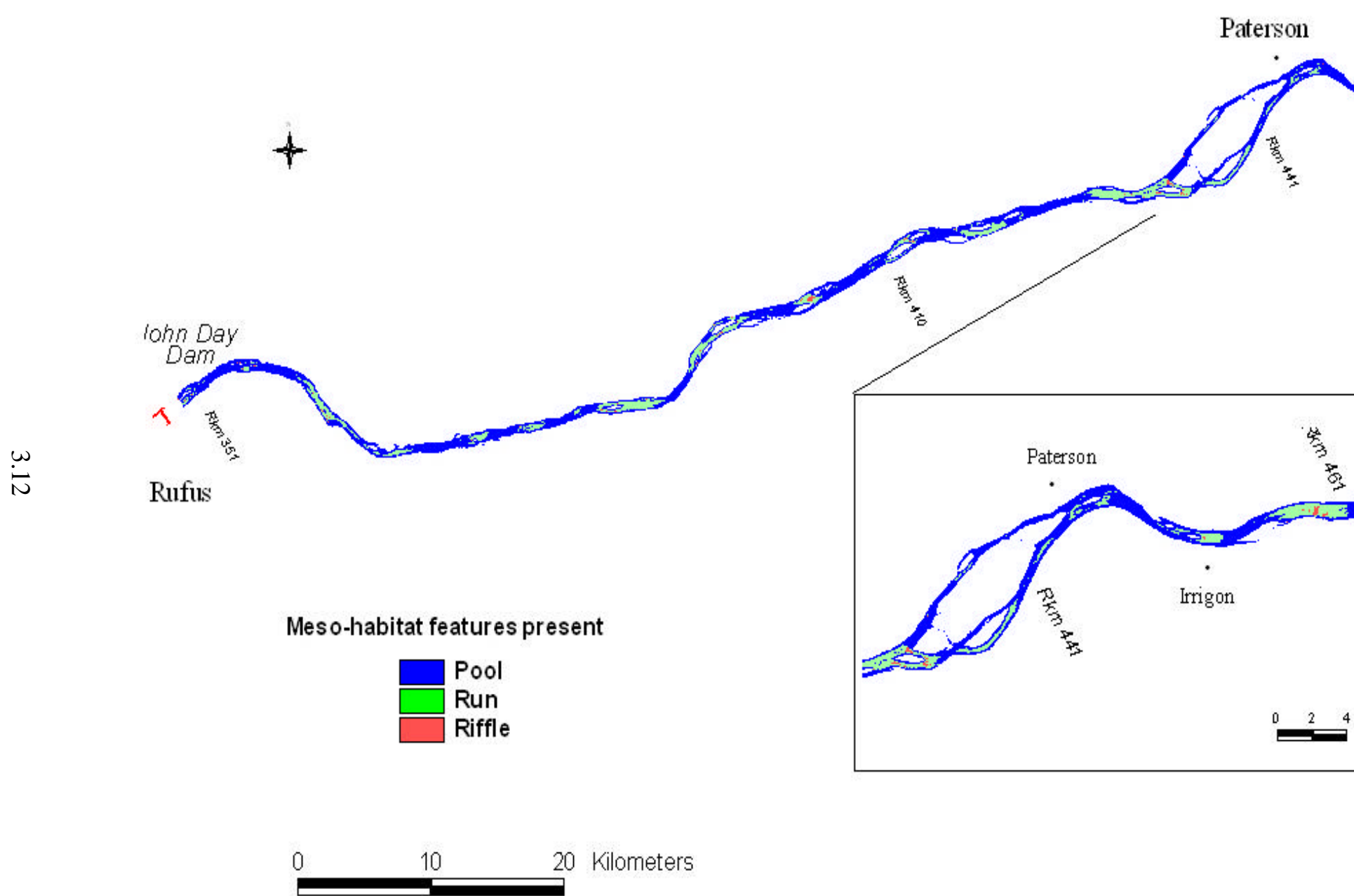

Figure 3.9. Distribution of Pools, Runs, and Riffles for Natural River Level (156 kcfs) Derived from Fr 


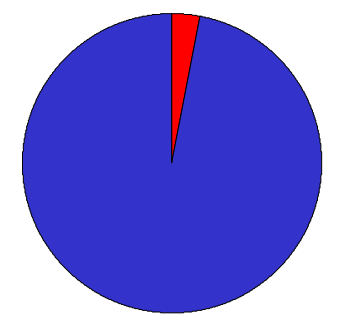

\section{Normal Operating Pool}

\section{Potentially \\ Suitable}

Not Suitable

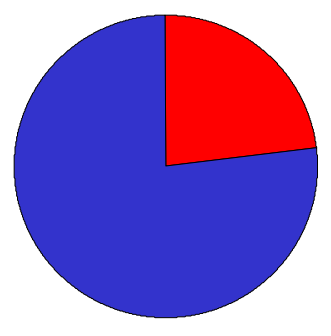

\section{Spillway Crest Pool}

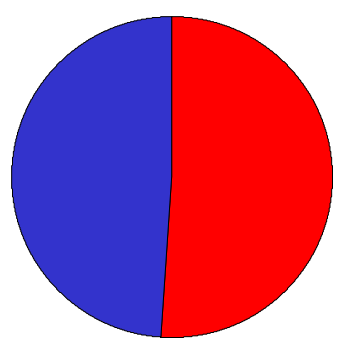

\section{Natural River}

\section{Summary of predicted habitat (in hectares)}

\begin{tabular}{|l|r|r|r|r|}
\hline condition & suitable (hectares) & \% of total & unsuitable (hectares) & $\%$ of total \\
\hline Natural $-\mathbf{1}$ & 4355 & 53 & 3922 & 47 \\
\hline Natural - & 4601 & 51 & 4472 & 49 \\
\hline Spillway Crest- 1 & 2455 & 22 & 8629 & 78 \\
\hline Spillway Crest- 2 & 2652 & 23 & 9118 & 77 \\
\hline Normal Pool - 1 & 434 & 2 & 19382 & 98 \\
\hline Normal Pool - 2 & 607 & 3 & 19233 & 97 \\
\hline
\end{tabular}

Figure 3.10. Percent of Suitable Fall Chinook Salmon Spawning Habitat Derived from Water Depth and Velocity. Summary table indicates an estimate of potentially suitable habitat acreage meeting the suitability criteria used. This is a liberal estimate of suitable habitat due to limitations in the availability of physical data sets. 


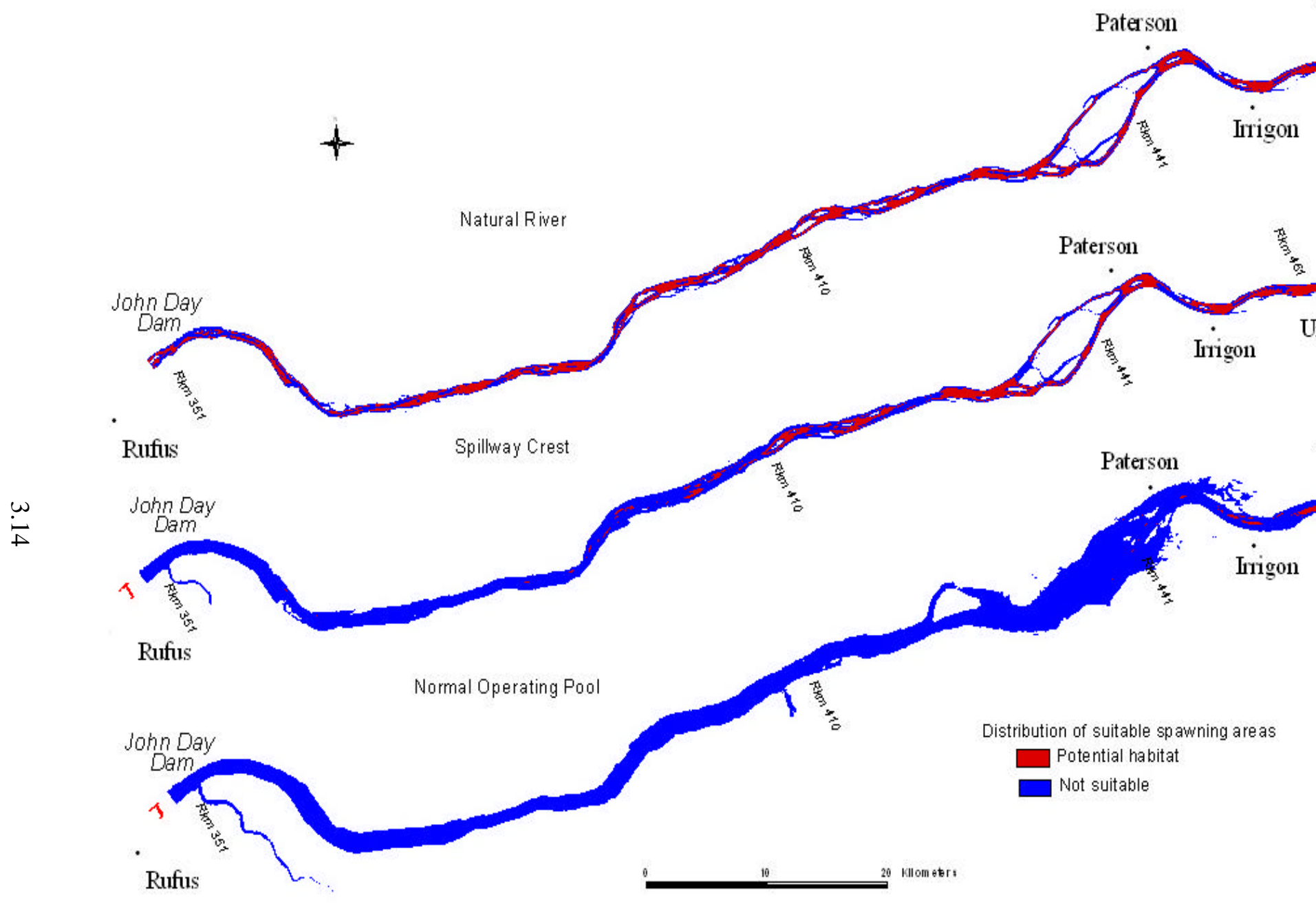

Figure 3.11. Distribution of Suitable and Unsuitable Fall Chinook Spawning Habitat Based on Water Depth Three Operational Scenarios 
river conditions, concentrated in the upper half of the pool (upstream of rkm 410) for spillway crest water level, and limited to the extreme upper end of the reservoir (upstream of rkm 455) for normal operating pool level.

\subsubsection{REARING HABITAT}

The amount of high probability rearing habitat for subyearling chinook salmon was highest for the natural river scenario at all flow regimes modeled (Table 3.1, Figure 3.12). Within the high probability habitat area, none was characterized as having probabilities $>0.85$ under normal operating pool. A general example of the differences between shoreline rearing habitat under normal operating pool and natural river level can be found in Figure 3.13. The normal operating pool scenario contained the lowest amount of high probability habitat, and the spillway crest scenario was intermediate for all flow regimes, except at $8495 \mathrm{~m}^{3} \mathrm{~s}^{-1}$. The natural river scenario contained 32, 28, and $13 \%$ more acres of rearing habitat than the normal operating pool scenario at 2832,4417 , and $8495 \mathrm{~m}^{3} \mathrm{~s}^{-1}$, respectively.

The total amount of rearing habitat for both natural river and spillway crest scenarios decreased as flow increased, whereas the total for the normal operating pool scenario increased slightly as flow increased. The amount of high probability rearing habitat at natural river decreased from 372 ha at 2832 $\mathrm{m}^{3} \mathrm{~s}^{-1}$ to 318 ha at $8495 \mathrm{~m}^{3} \mathrm{~s}^{-1}$ (Table 3.1). Similarly, rearing habitat at spillway crest decreased from 297 ha at $2832 \mathrm{~m}^{3} \mathrm{~s}^{-1}$ to 254 ha at $8495 \mathrm{~m}^{3} \mathrm{~s}^{-1}$. At normal operating conditions, the amount of rearing habitat increased from 253 ha at $2832 \mathrm{~m}^{3} \mathrm{~s}^{-1}$ to 278 ha at $8495 \mathrm{~m}^{3} \mathrm{~s}^{-1}$.

Table 3.1. Area (ha) and Percentages for Habitat Cells Containing 10 or More Subyearling Chinook Salmon Rearing Habitat for Normal Operating Pool, Spillway Crest, and Natural River Operational Scenarios at Flows Simulated at $2832 \mathrm{~m}^{3} \mathrm{~s}^{-1}$ (100 kcfs), $4417 \mathrm{~m}^{3} \mathrm{~s}^{-1}$ (156 kcfs), and $8495 \mathrm{~m}^{3} \mathrm{~s}^{-1}$ (300 kcfs) in John Day Reservoir. Habitat was classified as unusable, having a high probabilility $(>0.7)$, or having low probability $(<0.7)$. Areas having probabilities greater than 0.85 are included to illustrate the lack of the best habitat areas at normal pool operations. Total usable habitat is the sum of high and low probability areas.

\begin{tabular}{|c|c|c|c|c|c|c|c|c|c|}
\hline \multirow[b]{2}{*}{ Flow $\left(\mathrm{m}^{3} \mathbf{s}^{-1}\right)$} & \multicolumn{3}{|c|}{ Normal Operating Pool } & \multicolumn{3}{|c|}{ Spillway Crest } & \multicolumn{3}{|c|}{ Natural River } \\
\hline & 2832 & 4417 & 8495 & 2832 & 4417 & 8495 & 2832 & 4417 & 8495 \\
\hline Not used for rearing & 19,243 & 19,265 & 19,428 & 10,517 & 11,220 & 12,482 & 7,562 & 8,399 & 9,734 \\
\hline Probability $>0.85$ & 0 & 0 & 0 & 168 & 161 & 149 & 190 & 455 & 419 \\
\hline Probability $>0.7$ & 252 & 255 & 279 & 297 & 289 & 254 & 371 & 356 & 318 \\
\hline Probability $<0.7$ & 280 & 279 & 289 & 248 & 239 & 224 & 327 & 300 & 263 \\
\hline Total hectares & 19,775 & 19,799 & 19,995 & 11,062 & 11,748 & 12,861 & 8,260 & 9,055 & 10,315 \\
\hline Total usable & 532 & 534 & 568 & 545 & 528 & 478 & 698 & 656 & 581 \\
\hline$\%$ High probability & 1.3 & 1.3 & 1.4 & 2.7 & 2.5 & 2.0 & 4.5 & 3.9 & 3.1 \\
\hline$\%$ Total usable & 2.7 & 2.7 & 2.8 & 4.9 & 4.5 & 3.7 & 8.5 & 7.2 & 5.6 \\
\hline
\end{tabular}




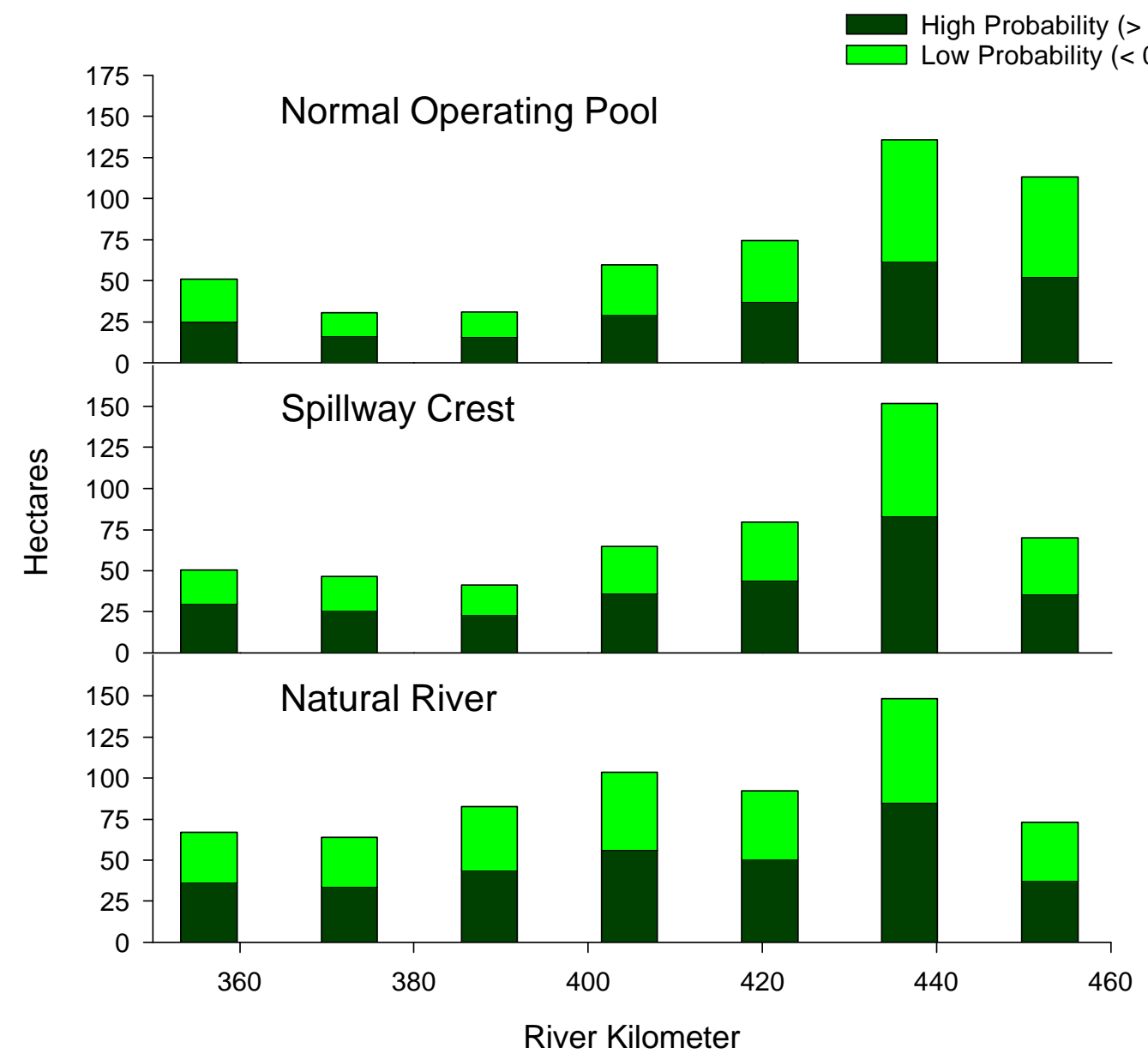

Figure 3.12. Acres of Rearing Habitat with High Probability $(>0.7)$ or Low Probability $(<0.7)$ for Habitat Cells Containing 10 or More Subyearling Fall Chinook Salmon at Normal Operating Pool, Spillway Crest, and Natural River Operational Scenarios in John Day Reservoir. Flows were simulated at $4417 \mathrm{~m}^{3} \mathrm{~s}^{-1}$ (156 kcfs).

A longitudinal profile of total rearing habitat in the John Day reservoir changed with operational scenarios and flow. For example, between rkm 348 and 397 the river channel was confined (Figure 3.1), but contained 39 to $59 \%$ more habitat under the natural river scenario than under normal operating pool scenario for all flows (Figure 3.14). Similarly, the spillway crest scenario resulted in an increase of high probability habitats compared to the normal operating pool (10 to 36\%).

Upstream of rkm 397, shoreline complexity increased, as did high probability rearing areas. This increase was particularly evident for the spillway crest and normal operating pool scenarios. Shoreline complexity and rearing habitat was greatest between rkm 429 and 445 (at Blalock Island) for all operational scenarios and flows. The natural river scenario resulted in the most total acres of rearing habitat followed by spillway crest and normal operating pool scenario at Blalock Island. However, upstream of Blalock Island, the normal operating pool scenario contained the most total acres of high probability rearing habitat followed by spillway crest and natural river scenarios. 

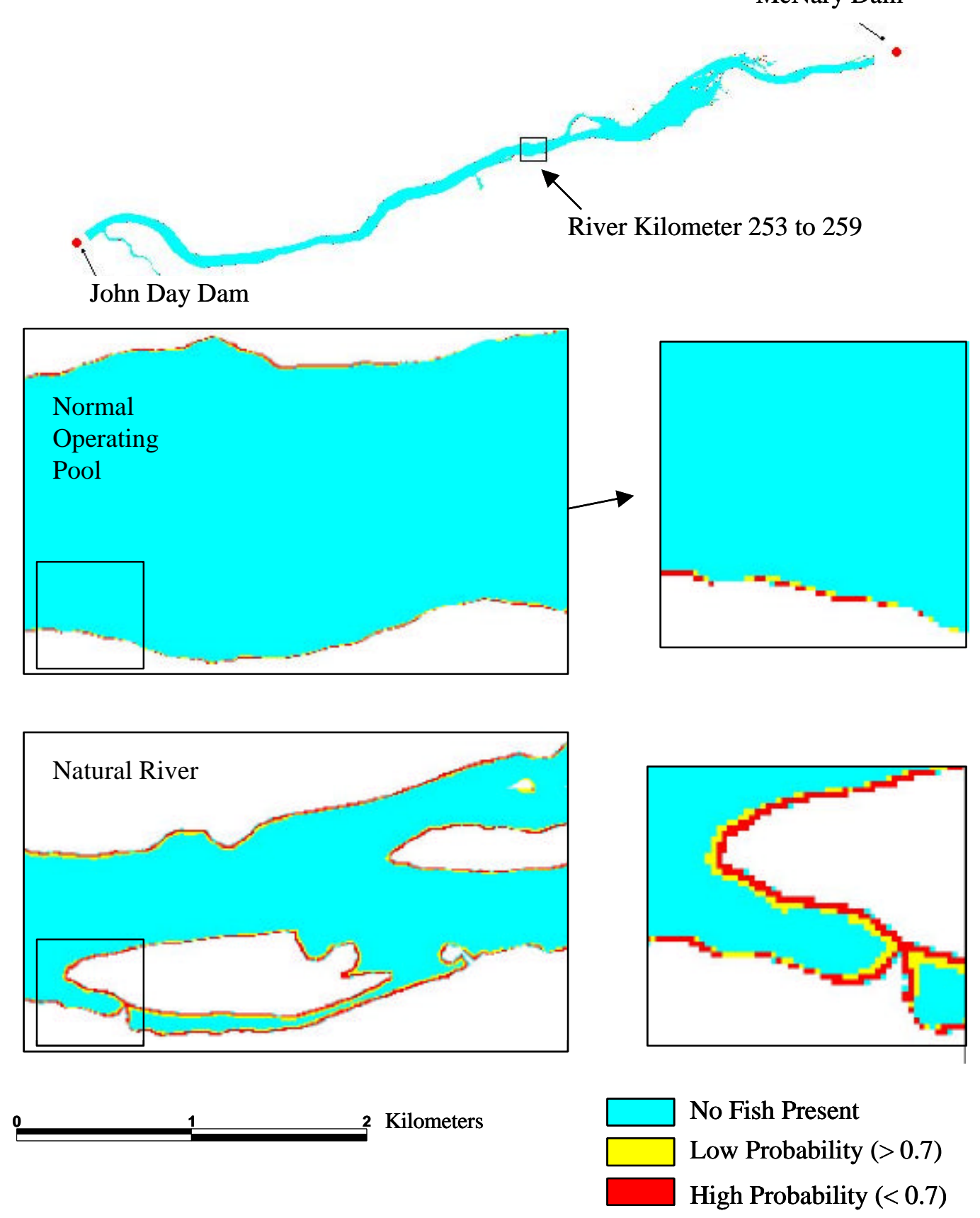

Figure 3.13. Example of Shoreline Fall Chinook Salmon Rearing Habitat Probabilities for John Day Reservoir at a Discharge of $4417 \mathrm{~m}^{3} \mathrm{~s}^{-1}$ (156 kcfs). Resolution of rearing habitat cells used in the analysis are $10 \mathrm{~m}^{2}$. 


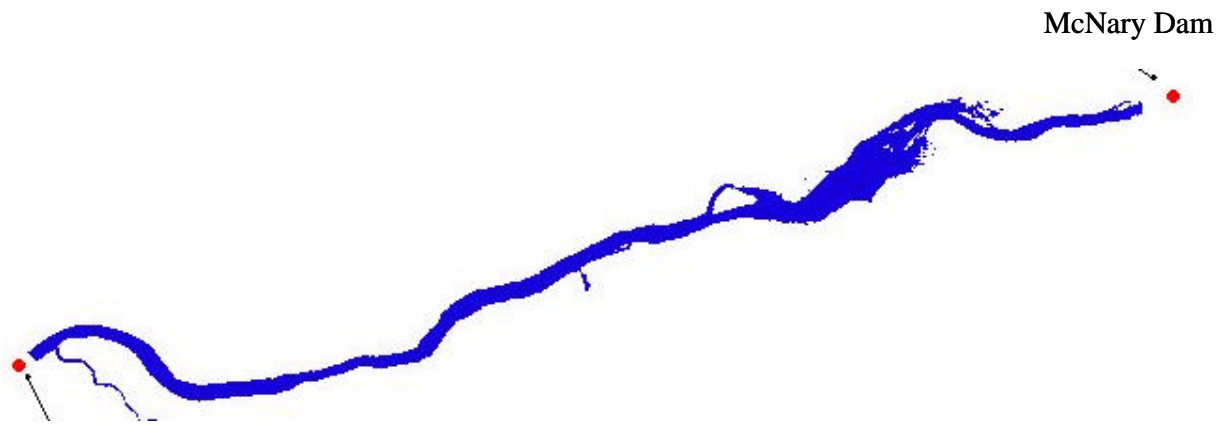

John Day Dam

High Probability $(>0.7)$

Low Probability $(<0.7)$

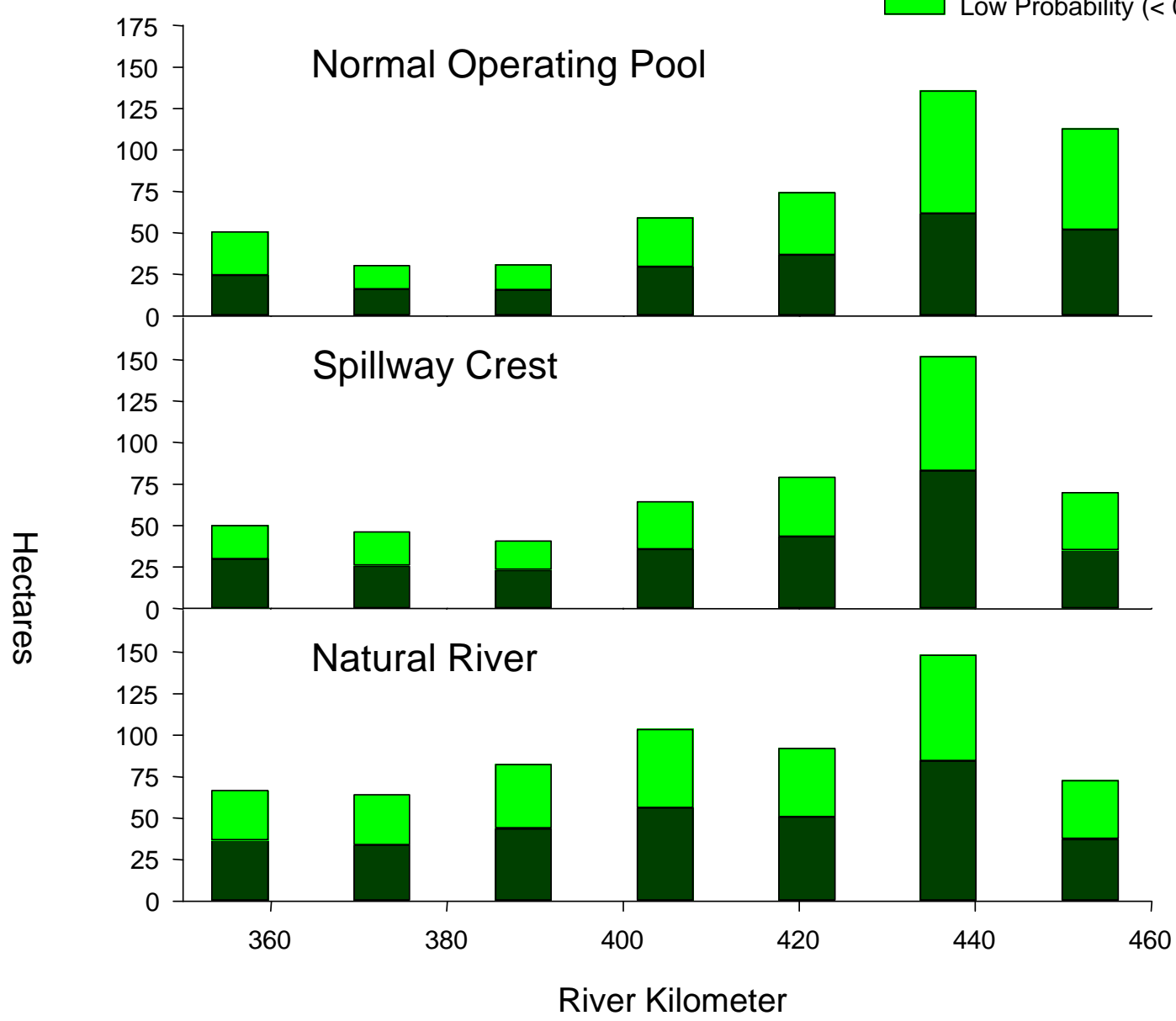

Figure 3.14. Acres of High Probability $(>0.7)$ and Low Probability $(<0.7)$ Subyearling Chinook Salmon Rearing Habitat by 16-km (10-Mile) Sections in John Day Reservoir, at Simulated Flows of $4417 \mathrm{~m}^{3} \mathrm{~s}^{-1}$ (156 kcfs) for Normal Operating Pool, Spillway Crest, and Natural River Operational Scenarios 


\subsection{DISCUSSION}

Complexity and diversity of aquatic habitat in John Day Reservoir varied with pool level and discharge scenarios. The reservoir is currently typified by deep-water habitat, with low channel complexity and a pool-run-riffle ratio skewed toward pools. The spillway crest restoration scenario provides increased complexity through the restoration of islands and shallow-water habitats in the upper third of the reservoir, while retaining deep-water habitats in the remainder of the reservoir. The natural river channel, now beneath John Day Reservoir, was typified by a complex channel pattern with a diversity of habitats in pools, runs, and riffles. Our analyses showed that changes in river morphology resulting from a reservoir drawdown to natural river water surface elevations provided significant increases in potential suitable spawning habitat for fall chinook salmon and slight increases in rearing habitat.

Partial or complete drawdown of the John Day Reservoir may restore historic habitats to some areas of the current reservoir, but other necessary hydrologic features must also be examined to fully assess the biological implications of this restoration strategy. Particular attention should be paid to the restoration of a seasonal hydrograph. For example, natural flood events and seasonal variations in river discharge historically had an important role in creating and maintaining the abiotic and biotic habitats in the river.

The scope of this study was limited by availability of existing data, and the results present a maximum-use scenario. Estimates of spawning and rearing habitat and meso-habitats presented used only distance from shore, water depths, and water velocities obtained by two-dimensional hydraulic modeling from existing digital data sets. The addition of more criteria would further refine the estimates of potential habitat.

Typically, habitat suitability models describing spawning habitats for salmon include features such as substrate, lateral bed slope, bed scour, and small-scale geomorphic river features such as hyporheic flow (Milhous 1979; Stalnaker 1979; Conner et al. 1994; Geist and Dauble 1998; Geist 1998). Geist (1998) found that water velocity and lateral bed slope were the most important variables in predicting redd sites in the Hanford Reach. The areas of potential spawning habitat described in our study indicate those potentially suitable for fall chinook spawning and may not reflect where redds were located historically. Our study predicts where spawning could occur, rather than predicting exactly where spawning would occur if reservoir drawdown were implemented.

We compared the amount of spawning habitat predicted for this study at rkm 418 through rkm 470 using methods described in Sheer (1999). Sheer (1999) estimated the spatial distribution of historic spawning habitat for fall chinook salmon under natural river conditions to be 1,514 ha or about $12 \%$ lower than the estimate for the present study. However, Sheer (1999) used riverbed elevations derived from historic maps to model natural river level water velocities, whereas the riverbed elevations used to model velocities for natural river level in this study were based on more recent information. Recent riverbed elevations have been affected by dredging and deposition of sediments that has occurred since the construction of John Day Dam. Sheer (1999) also modeled water velocities at a river discharge that was lower (75 kcfs) than the lowest discharge used in this study (100 kcfs). 
Comparison of the three water level scenarios showed that restoration to natural river water levels should result in more potential rearing habitat for fall chinook salmon than would maintaining normal operations or a reservoir drawdown to spillway crest. Shallow shoreline areas provide warmer water temperatures for faster growth, lower risk of predation from fish, and are preferred by juvenile fall chinook salmon (Key et al. 1994a, 1996). The greatest increases in rearing habitat would occur in the lower, more confined portion of the reservoir. In this area, the channel morphology under natural river water levels results in shallower water and lower lateral gradients near shore. In addition, shoreline water velocities are higher under natural river levels. Juvenile fall chinook salmon prefer these conditions over still-water habitats (Murphy et al. 1989; Key et al. 1994a).

Estimates of potential rearing habitat for fall chinook salmon in John Day reservoir are based on an analysis of existing measured river bed elevations, which were used as input into hydraulic models to derive other criteria such as water velocities, depths, and distance from shore. Using this derived information, the classifications of fish presence or absence within discrete habitat cells using our discriminant function were $47 \%$ better than random chance. The large-scale resolution of the available geographic data (10- x 10-m cells) limited the detection of fine-scale microhabitat variations, and may have biased our estimates of potential rearing habitat upward, particularly estimates under normal operating conditions. One habitat variable that was unavailable for inclusion in our GIS-based analysis was substrate. Garland et al. (in review) showed that juvenile fall chinook salmon avoid large substrates such as riprap. Since much of the shoreline of John Day reservoir is armored with riprap, it is unlikely that juvenile fall chinook salmon would use such habitats for rearing even if water depths and velocities were suitable. This means that fall chinook production is more limited under normal operating conditions than our analyses indicate. It was also not possible to account for more complex biological components of rearing habitat within the scope of this study. In spite of these limitations, our estimates of potential rearing habitat are useful for comparing operational and restoration strategies for fall chinook salmon in John Day reservoir.

River environments produce a more diverse and higher quality food supply for fall chinook salmon (Becker 1973; Dauble et al. 1980) than do reservoir habitats (Rondorf et al. 1990; Muir and Emmett 1988), and should have greater potential for production of fall chinook salmon. Higher water velocities found in riverine systems promote a diversity of substrates and microhabitats that result in richer, more abundant invertebrate communities similar to those found in the Hanford Reach and the Hells Canyon Reach (USGS, unpublished data). Currently, riverine conditions between John Day and McNary dams occur only in the extreme upper reaches of the reservoir. The analyses presented here show that lowering water levels at John Day Dam to spillway crest restores riverine conditions to about one third of the current reservoir. Lowering water levels to the natural river affords the greatest opportunity for riverine processes to shape habitats and increase fall chinook salmon production. 


\section{REMOVAL OF FOUR LOWER SNAKE RIVER DAMS}

\subsection{INTRODUCTION}

Snake River populations of salmon and steelhead have declined during the last 30 years, leading to their protection under the Endangered Species Act. In 1991, Snake River sockeye salmon (O. nerka) were listed under the ESA as endangered. In 1992, Snake River spring/summer and fall chinook salmon (O. tshawytscha) were listed as threatened. In 1998, Snake River steelhead (O. mykiss) were listed as threatened. These listings prompted the National Marine Fisheries Service (NMFS) to call for an evaluation of structural and operational modifications to the four hydroelectric dams operated by the USACE on the lower Snake River (NMFS 1995; NMFS 1998).

There has been a nearly continuous reservoir system on the lower Snake River since the construction of the four lower Snake River dams from 1961 to 1975 . The only areas currently exhibiting riverine characteristics are the tailraces downriver of each dam. The lack of riverine habitat has impacted the life history strategies (e.g., juvenile migration from tributary to ocean) for all populations of Snake River salmonids.

One option for restoring mainstem habitats and riverine processes important to Snake River salmon and steelhead is natural river drawdown. This management option entails removal of the earthen portion of each of the four lower Snake River dams, allowing the river to return to its pre-dam channel. Much of the infrastructure at each dam would remain in place, and a new channel would be routed around the remaining structures. The Independent Scientific Group (ISG 1996) and NMFS (1998) have suggested this option could be beneficial not only to migrating juvenile salmonids, but also to those salmonids that spawn and rear in the mainstem Snake River (e.g., fall chinook salmon and steelhead).

The research described herein set out to address the question, "To what extent can mainstem habitats and riverine processes required for salmon production be achieved by natural river drawdown?" We focused on three objectives for this study. The first objective was to describe the physical characteristics and habitats of the pre-dam river. Characterizing and quantifying the pre-dam channel morphology provides a starting point for determining future channel characteristics and habitats because it establishes the difference between known pre-dam channel morphology and current conditions. The second objective was to quantify the geomorphic features that describe salmon production areas. The third objective was to evaluate changes in the flow regime under natural river drawdown-perhaps the most important controlling factor of channel morphology and riverine processes. This objective is particularly important because the river will continue to be influenced by regulated flows from the operation of upstream storage reservoirs and hydropower facilities located on the mainstem Snake River and tributaries (e.g., the Hells Canyon Dam complex in the middle Snake River, and Dworshak Dam on the North Fork of the Clearwater River). The regulated flow regimes must be competent enough to erode and transport fine sediments accumulated in the reservoirs since dam construction and to maintain other geomorphic processes (e.g., channel bed mobilization). 


\subsection{STUDY AREA}

The study area extended from the mouth of the Snake River (at its confluence with the Columbia River) to $266 \mathrm{~km}$ upriver near the confluence with the Grande Ronde River (Figure 3.15). Mean annual discharge at the uppermost dam in the study area (Lower Granite Dam) is $1410 \mathrm{~m}^{3} \mathrm{~s}^{-1}$ (49,800 cfs), while mean annual peak discharge is approximately $5012 \mathrm{~m}^{3} \mathrm{~s}^{-1}(177,000 \mathrm{cfs})$. Elevations in the study area range from 90 to $1035 \mathrm{~m}$ (340 to $3000 \mathrm{ft}$ ) above MSL, including areas of broad valleys with gentle slopes and areas of deep, confined canyons with steep walls.

The lower Snake River valley has a complex geologic history. Basalt bedrock originating during periods of volcanism between 17 and 6 million years ago represents much of the current river valley (Schuster et al. 1997), forming steep, bedrock-exposed valley walls known as the Snake River breaks. About 14,500 years ago, Pleistocene Lake Bonneville in present-day northern Utah spilled over and flooded into the Snake River valley, depositing significant amounts of alluvium with clast diameter ranging in size from $<10 \mathrm{~cm}$ to $>10 \mathrm{~m}$ (O'Connor 1993). The flood followed the course of the presentday Snake and Columbia rivers before entering the Pacific Ocean (O'Connor 1993). Subsequent flood events (as many as 100) from glacial Lake Missoula between 14,500 and 12,000 years ago deposited immense amounts of gravel, sand, and silt over the Bonneville Flood deposits in the lower end of the study area (Baker and Bunker 1985; O’Connor 1993).

\subsection{METHODS}

\subsubsection{COARSE-SCALE GEOMORPHIC CHARACTERIZATION}

Characterization of the lower Snake River began with an evaluation of the watershed-scale controlling factors of channel morphology (e.g., geology, physiography, longitudinal profile, and discharge). This initial level of assessment allowed us to classify the 266-km study area into distinct geomorphic units. This classification was based on parameters that provided indicators of channel-forming processes, channel morphology at the reach scale, and reach-scale response potential to change.

The coarse-scale (level 1) classification was based on geology, physiography, and channel planform. The geologic data originated at a scale of 1:500,000 and contained descriptions of geologic formation, rock type, age, and major lithology (Johnson and Raines 1996; Raines and Johnson 1996). The lower Snake River valley was subsequently classified into three classes based on geologic formations: unconsolidated sediments, bedrock, and mixed unconsolidated/bedrock. The geologic classification was then compared with a 1:250,000 scale hard copy map of geologic features in the study area (Schuster et al. 1997). The geologic features within $1.6 \mathrm{~km}(1 \mathrm{mi})$ of the river channel were used in the level 1 classification.

Assessment of physiography involved evaluation of river valley morphology, including an interpretation of structural controls and lithology, landforms, and fluvial processes. Primary attention was given to the relation between the river channel and the valley walls, providing an indication of the lateral and vertical control the valley imposes on the river. Interpretation of these features and processes was based 


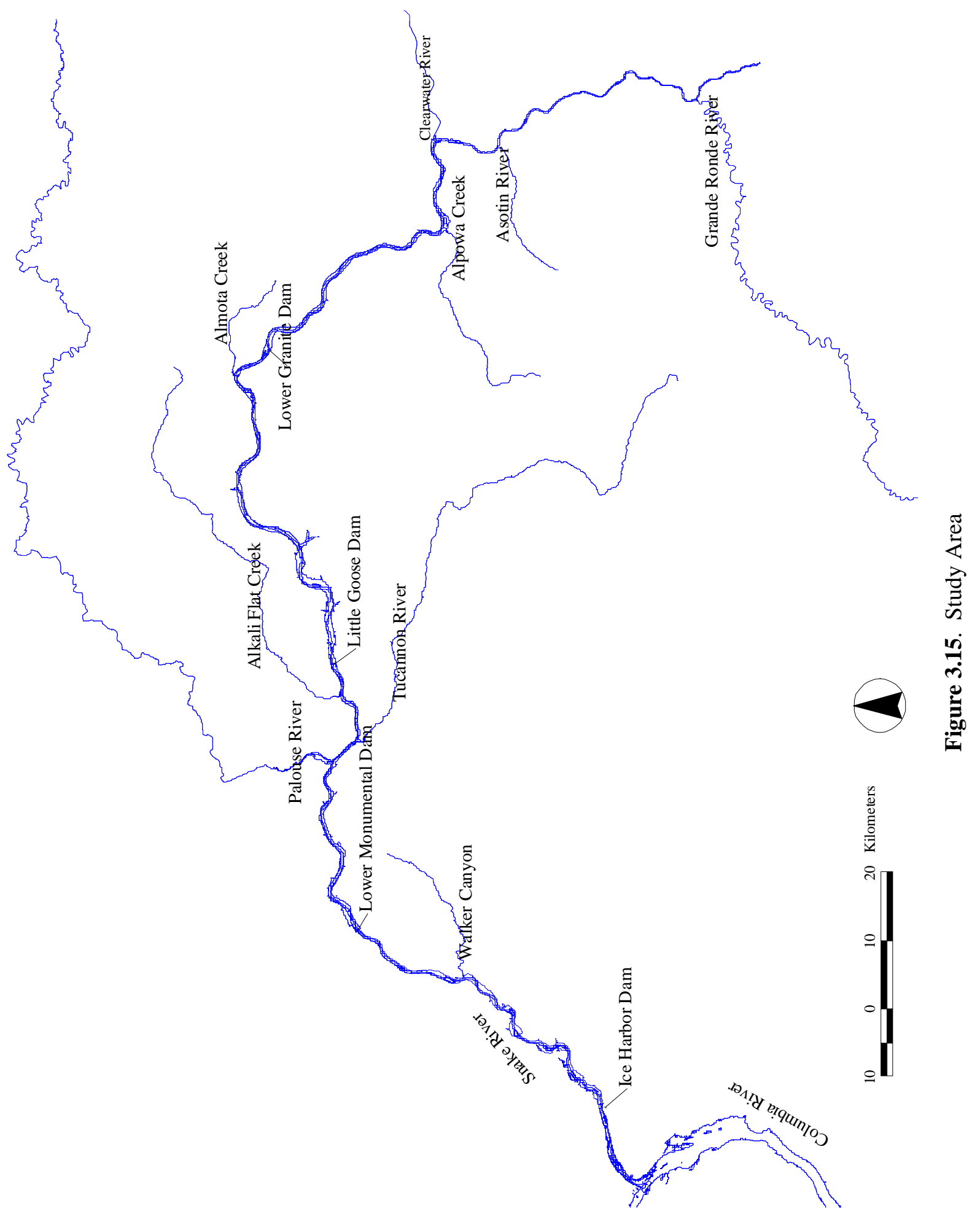


on models of landform that were incorporated into the GIS. Individual DEMs with a 30-m cell resolution and a scale of 1:24,000 were combined into one DEM for the entire study area. The resulting DEM was subjected to a hillshading algorithm, which allows for easy visual distinction of topographical relief. A similar hillshaded DEM model was built for the river channel (bathymetry) and near-shore topography for the entire study area. That DEM was based on depth soundings taken during low flow periods in 1933 and 1934 that the USACE mapped at 1:2000 for the entire study area. Near-shore topography up to several hundred feet in elevation was also mapped at 1:2000. These data were incorporated into the GIS and transformed into a three-dimensional surface for producing the hillshaded DEM. The resulting DEMs were interpreted for the presence of different valley types (i.e., broad, gently sloping valley walls vs. deep, confined, steep-sloped valley walls), structural containment by the valley walls, and fluvial processes (e.g., scour and fill) within the river channel. The physiographic interpretation resulted in two classes being used for the level 1 classification: confined and moderately confined. These two classes describe the degree of structural confinement of the channel within the valley walls. Confinement was generally indicated where the channel occupied the majority of the valley bottom, with little alternate bar (channel side bar) development.

Channel planform was the final parameter used in the level 1 classification. The 1:2000 scale predam USACE maps were incorporated into the GIS. The maps depict shoreline, islands, and bars at low flow. The level 1 classification included channel pattern (i.e., sinuosity) and depositional features (i.e., islands and bars). River sinuosity $P$ was used to indicate how the river has adjusted its slope relative to the slope of its valley. For a given river segment, $P$ was calculated as the ratio of river channel length to valley length (Richards 1982).

Planform depositional features were incorporated into the level 1 classification by delineating river segments into two classes: islands or bars present, islands or bars absent. Only genetic features-those constructed by the present-day river through the course of lateral shifting or flooding (Kellerhals et al. 1976; Kellerhals and Church 1989)-were included in the classification. The term "genetic features" is used to differentiate them from terraces deposited during cataclysmic events (e.g., the Bonneville Flood) that were constructed at elevations exceeding present-day peak flood stages. Genetic features were interpreted from the pre-dam maps and hillshaded DEMs based on their elevation relative to the water surface elevation.

The level 1 classification was completed by using GIS map overlay techniques based on data layers depicting geology, physiography, and channel planform. The data layers were combined to determine if spatial relationships occurred among the three characteristics.

\subsubsection{REACH-SCALE CLASSIFICATION (LEVEL 2)}

Characterization of the lower Snake River at the reach scale was based on analysis of hydraulic geometry and channel morphology at sampled cross sections. Hydraulics at each cross section were simulated using both one-dimensional (MASS1) and two-dimensional (MASS2) unsteady flow models developed at Pacific Northwest National Laboratory (Richmond and Perkins 1999). MASS1 was used to estimate cross-section averages of hydraulic parameters, while MASS2 was used to estimate depthaveraged hydraulic parameters in a horizontal plane (e.g., lateral variation in velocity). The physical basis 
for the cross sections was the pre-dam channel morphology data (i.e., bathymetry surface and planform characteristics) incorporated into the GIS from the 1934 USACE maps. A total of 338 cross sections, spaced 0.4 to $0.8 \mathrm{~km}$ apart, were placed in the $266 \mathrm{~km}$ study area for the MASS1 modeling. MASS2 modeling results were extracted at cross sections space $0.16 \mathrm{~km}(0.1 \mathrm{mi})$ apart to identify fine-scale lateral and longitudinal variations in the hydraulic parameters. The models were run for flow scenarios approximating the 10,50 , and $90 \%$ exceedence discharges $\left[Q_{10}=3157 \mathrm{~m}^{3} \mathrm{~s}^{-1}(111,500 \mathrm{cfs}), Q_{50}=898 \mathrm{~m}^{3} \mathrm{~s}^{-1}\right.$ (31,710 cfs), $\left.Q_{90}=472 \mathrm{~m}^{3} \mathrm{~s}^{-1}(16,680 \mathrm{cfs})\right]$, respectively) based on 67 year of mean monthly flow at Lower Granite Dam. At each cross section, MASS1 model outputs included average estimates of discharge, water surface elevation, velocity, thalweg elevation, cross-sectional area, and hydraulic radius. Three additional characteristics for each cross section were computed from these estimates: width to depth ratio $F$, water surface slope $S$, and entrenchment ratio $E R$. The level 2 classification used $F$ and $S$ values based on the $Q_{50}$ hydraulic results. The $E R$ characteristic for the level 2 classification was based on the ratio of the top width for the $Q_{10}$ flow (i.e., high flow) to the top width for the $Q_{50}$ flow. The ER characteristic is used as an index of channel shape and entrenchment, where values approaching one indicate an entrenched channel capable of containing a high flow within its banks (Rosgen 1996).

Channel substrate data were incorporated into the level 2 classification based on handwritten notations from the 1934 USACE maps. These notes provided only a general idea of grain sizes and spatial distribution and were incorporated into the GIS as point samples. The notes for each point sample were converted into one of five classes according to the appropriate AGU grain size classification (Table 3.2). The qualitative nature of the substrate data led to a further reclassification by grouping grain size classes (Table 3.2). A resulting substrate class was then assigned to each cross section (Hanrahan et al. 1999).

The level 2 classification proceeded by assigning a value for each characteristic $(D, F, S, E R)$ to each cross section (Table 3.3). The level 2 class of a given cross section was determined by combining its level 1 class with its $D, F, S$, and $E R$ values (see Table 3.4 for an example).

Table 3.2. Grain Size Classification

\begin{tabular}{|l|l|}
\hline \multicolumn{1}{|c|}{ Size Class } & Grain Diameter $(\mathbf{m m})$ \\
\hline Bedrock & \\
\hline Boulder & $>256$ \\
\hline Cobble & $64-256$ \\
\hline Gravel & $2-64$ \\
\hline Sand & $0.0625-2$ \\
\hline
\end{tabular}


Table 3.3. Level 2 Characteristics

\begin{tabular}{|l|l|l|}
\hline \multicolumn{1}{|c|}{ Level 2 Characteristic } & \multicolumn{1}{|c|}{ Definition } & \multicolumn{1}{c|}{ Code } \\
\hline Substrate $(D)$ & $\begin{array}{l}\text { Bedrock/boulder } \\
\text { Cobble/gravel } \\
\text { Sand }\end{array}$ & $\begin{array}{l}D 1 \\
D 34 \\
D 5\end{array}$ \\
\hline $\begin{array}{l}\text { Width:Depth ratio }(F) 50 \% \\
\text { exceedence flow }\end{array}$ & $\begin{array}{l}\text { Low to moderate, }<20 \\
\text { Moderate to high, >=20 }\end{array}$ & $F-$ \\
\hline $\begin{array}{l}\text { Water surface slope }(S) \text { 50\% } \\
\text { exceedence flow }\end{array}$ & $\begin{array}{l}\text { Low to moderate, }<0.001 \\
\text { Moderate to high, >=0.001 }\end{array}$ & $S-$ \\
\hline $\begin{array}{l}\text { Entrenchment ratio }(E R) \\
\text { Width of } 10 \% \text { to width of } \\
50 \% \text { exceedence flow }\end{array}$ & $\begin{array}{l}\text { Entrenched, }<1.4 \\
\text { Moderate, }>=1.4\end{array}$ & $E R-$ \\
\hline
\end{tabular}

Table 3.4. Example and Description of Level 2 Classification

\begin{tabular}{|l|l|l|l|l|l|}
\hline Level 2 Class: & \multicolumn{4}{|l}{ F_bi D34 F+ S- ER- } \\
\hline Characteristic: & F_bi & D34 & $F+$ & S- & ER- \\
\hline Description: & $\begin{array}{l}\text { See level } \\
1 \text { code }\end{array}$ & $\begin{array}{l}\text { Dominated by } \\
\text { cobble/gravel } \\
\text { substrate }\end{array}$ & $\begin{array}{l}\text { Moderately } \\
\text { high width to } \\
\text { depth ratio }\end{array}$ & $\begin{array}{l}\text { Low to } \\
\text { moderate water } \\
\text { surface slope }\end{array}$ & $\begin{array}{l}\text { Entrenched } \\
\text { within the } \\
\text { valley bottom }\end{array}$ \\
\hline
\end{tabular}

\subsubsection{ADDITIONAL HYDRAULIC AND GEOMORPHIC CHARACTERISTICS}

Hydraulic parameters and indices of channel shape were also summarized for each cross section. The $Q_{50}$ flow was used to calculate mean depth, width, and velocity, width to depth ratio $(F)$, maximum depth to mean depth ratio $\left(d_{\max } / d\right)$, and unit stream power $(\omega)$. Stream power per unit bed area was calculated as

$$
\omega=\rho g d v s_{e}
$$

where $\rho$ is the fluid density, $g$ is gravitational acceleration, $d$ is depth, $v$ is velocity, and $s_{e}$ is the energy slope approximated by the water surface slope.

Additional spatial assessment of pool, run, and riffle/rapid habitat features was completed based on hydraulic modeling results. Typical parameters used include combinations of velocity/depth ratio, Froude number, and water surface slope. These parameters are typically calibrated to visual assessments of pool, run, and riffle habitat types made during field visits. Once calibrated, the parameters are used to predict the quantity and spatial composition of the habitat features (Jowett 1993). The physical criteria used to delineate habitat features (e.g., velocity/depth ratio $<1.24$ indicates pool habitat) is specific to the river for which the criteria were developed and are generally not transferable to different rivers. This required us to correlate visual estimates of pool, riffle, run habitat from pre-dam maps with hydraulic parameters estimated through modeling. The spatial assessment of pool, run, and riffle/rapid habitats for the lower 
Snake River was based on the calculated velocity/depth ratio for the $Q_{50}$ flow. The linear (upstream/ downstream) extent of some rapids was depicted on the 1934 pre-dam maps and was digitized into a GIS data layer. Pool, riffle, or other similar habitat types were not depicted on the 1934 pre-dam maps, and therefore, could not be used for correlating hydraulic estimates. The extent of pre-dam rapids was plotted on the GIS on top of the data layer depicting velocity/depth ratio. This map overlay was used to determine the velocity/depth criteria distinguishing rapids from other habitats. Criteria distinguishing pool and run habitats was estimated based on an interpretation of the remaining velocity/depth ratios and channel morphology. The habitat criteria were based on the following velocity/depth ratios: pool $0.0-0.50$, run $0.51-1.20$, riffle/rapid: $>1.20$.

\subsubsection{GEOMORPHIC FEATURES AND SALMON PRODUCTION AREAS}

All quantitative data sets for fall chinook salmon spawning locations and associated redd densities, representing all hydro development periods (pre, concurrent, post), were incorporated into the GIS through the use of dynamic segmentation (see Chapter One for a description of spawning records). These data sets were built as linear event tables containing locational information (e.g., from rkm to rkm), attribute data, and data base keys linking to the reference source for the attribute data. The event tables were then linked to their location in the lower Snake River through the use of 1:100,000 scale PNW RRF obtained from the USGS and StreamNet. These files include GIS data layers containing line segments that represent the channel midline.

We used the geology and planform data layers to quantify the geologic composition and availability of depositional features along the lower Snake River. The 1:100,000 scale PNW RRF were segmented into 500-m linear sections and used as the base layer for delineating geologic and depositional features. The delineation of these features correlated spatially with the delineation of fall chinook spawning locations described earlier.

The geologic composition of the right and left bank (facing downriver) for each 500-m segment was estimated through the use of nearest neighbor analysis in the GIS. Each 500-m segment was assigned the geologic attributes (geologic formation, rock type, age, major lithology, and bedrock/unconsolidated classification) of the nearest right bank and left bank geologic unit. A composite geologic typing of each 500-m segment was calculated by averaging the right and left bank bedrock/unconsolidated classification. Thus, each 500-m segment could be one of three types: 100\% unconsolidated, 50/50\% unconsolidated/ bedrock, $100 \%$ bedrock. The same composite geologic typing was completed for longer contiguous river sections as well (e.g., 32-km spawning section), resulting in different percentages of geologic composition for these sections as a whole.

Planform depositional features (bars and islands) were interpreted from planform GIS data layers. The data layers used included those depicting right- and left-bank shorelines, cutoff channels, islands, and near-shore topography (contour lines and hillshaded DEMs). Depositional features were incorporated into the analysis by delineating each 500-m segment into one of three classes: islands or bars present, islands or bars absent, and unknown. Only genetic features were included in the classification. A 
composite depositional typing for contiguous river sections (e.g., 32-km) spawning section] was calculated by determining the proportion of a given contiguous section classified as depositional features present, absent, and unknown.

Based on the relationship between redd densities and the geomorphic features described above (see Chapter One for a full description), we created a geomorphic spawning habitat model where segments of river were considered usable if they contained greater than 50\% unconsolidated sediment, contained bars and/or islands, and were $<0.0005$ in longitudinal gradient. River segments that met these criteria were considered suitable fall chinook salmon production areas while those that failed to meet all the criteria were considered unsuitable spawning habitat.

\subsubsection{FLOW REGIME AND SEDIMENT TRANSPORT}

Flow records analyzed for this study represent discharge of the Snake River near the upriver end of the study area and downriver of the confluence with the Clearwater River. Daily discharge records for the period January 1, 1929 through December 31, 1973 were obtained from the USGS gage (13343500) near Clarkston, Washington. This gage was discontinued after December 31, 1973. To estimate daily discharge at the same location after this period, we summed the discharges from three different gages approximating the total aggregate flow to that location. Daily discharge records for the period January 1 , 1974 through June 30, 1996, were obtained from the USGS gages on the Snake River near Anatone (13334300), on Asotin Creek near Asotin, Washington (13334700), and on the Clearwater River at Spalding, Washington (13342500). The discharge record for Asotin Creek ends at June 30, 1996, but was extended through linear regression with the USGS gage on the Grande Ronde River (13333000) to be coincident with the time steps of the other gages. Total discharge for the period July 1, 1996, through September 30, 1998, was estimated by summing the daily records from the Anatone gage, the extended Asotin Creek records, and the Spalding gage.

The flow regime for the time period before major hydroelectric development (pre-major storage, 1929 to 1958) was assumed to be indicative of the flow regimes that shaped and maintained the river during that period. The flow regime after major hydroelectric development (post-major storage, 1959 to 1998) was assumed to be indicative of the flow regimes that will persist into the future, even after modification of the four lower Snake River dams. The constructed flow record represents discharge upriver of the four lower Snake River dams and downriver from the hydroelectric dams and storage reservoirs that will be unaffected by modifications to the lower Snake River dams.

The limited availability of present substrate conditions in the entire lower Snake River inhibits the estimation of sediment transport following natural river drawdown. The most data available are for that

area upriver of Lower Granite Dam. Estimates of the time required to remove sediment accumulated in Lower Granite reservoir were based on estimates of available sediment and one-dimensional hydrodynamic modeling simulations (see Hanrahan et al. [1998] for details). 


\subsection{RESULTS AND DISCUSSION}

\subsubsection{COARSE-SCALE GEOMORPHIC CHARACTERIZATION (LEVEL 1)}

Although when viewed in planform the lower Snake River exhibits a meandering course, geomorphologically it is a straight or slightly sinuous river $(P \leq 1.2)$. The river possesses the characteristics of passive meandering, where the planform pattern is imposed by the local landform (Richards 1982; Thorne 1997). This characteristic is distinct from completely self-formed alluvial channels that are actively and freely forming the valley bottom (active meandering). Because of the homogeneity of low $P$ values throughout the study area, sinuosity was not a primary determining factor in the coarse-scale classification.

The lower Snake River was delineated into three classes (Table 3.5). The study area contains $14 \%$ of the $\mathrm{C}_{\mathrm{bi}}$ class, $26 \%$ of the $\mathrm{F}$ class, and $60 \%$ of the $\mathrm{F}_{\mathrm{bi}}$ class (Figure $3.16 \mathrm{a}-\mathrm{c}$ ). Most alluvial or partially alluvial reaches of the lower Snake River fall under the level 1 classifications of $\mathrm{C}_{\mathrm{bi}}$ and $\mathrm{F}_{\mathrm{bi}}$. Bedrockconfined and colluvial reaches are found mostly in the areas of level $1 \mathrm{~F}$ classifications. Two general areas within the lower Snake River are classified as $\mathrm{C}_{\mathrm{bi}}$ : from the mouth upriver to approximately rkm 26, and near the confluence with the Clearwater River from rkm 216 to 229. For comparison, the Hanford Reach, the most important production area for fall chinook salmon in the Columbia River Basin (Dauble and Watson 1997), is also classified as $\mathrm{C}_{\mathrm{bi}}$ when using the same classification methods used in this study. Areas classified as $\mathrm{F}_{\mathrm{bi}}$ are sporadic, with one large contiguous section extending from approximately rkm 106 to 193 (rm 66 to 120). The distribution of areas classified as F is similarly patchy, although one large section extends from approximately rkm 71 to 106 . Within each level 1 class, a diversity of channel forms was classified at the cross section scale (level 2).

Table 3.5. Level 1 Classification

\begin{tabular}{|l|l|}
\hline \multicolumn{1}{|c|}{ Level 1 Code } & \multicolumn{1}{c|}{ Description } \\
\hline C_bi & $\begin{array}{l}\text { The major lithology is dominated by unconsolidated sedimentary rocks and } \\
\text { deposits. The river channel is moderately confined by the valley/canyon walls; } \\
\text { indicating it is neither totally confined nor totally unconfined. Bars and/or } \\
\text { islands are present. }\end{array}$ \\
\hline F_bi & $\begin{array}{l}\text { The major lithology is a mix of unconsolidated sedimentary rocks/deposits and } \\
\text { basalt bedrock. The river channel is moderately confined by the valley/canyon } \\
\text { walls; indicating it is neither totally confined nor totally unconfined. Bars and/or } \\
\text { islands are present. }\end{array}$ \\
\hline F & $\begin{array}{l}\text { The major lithology is a mix of unconsolidated sedimentary rocks/deposits and } \\
\text { basalt bedrock. The river channel is highly confined by the valley/canyon walls, } \\
\text { and occupies almost the entire valley bottom. Bars and/or islands are absent. }\end{array}$ \\
\hline
\end{tabular}




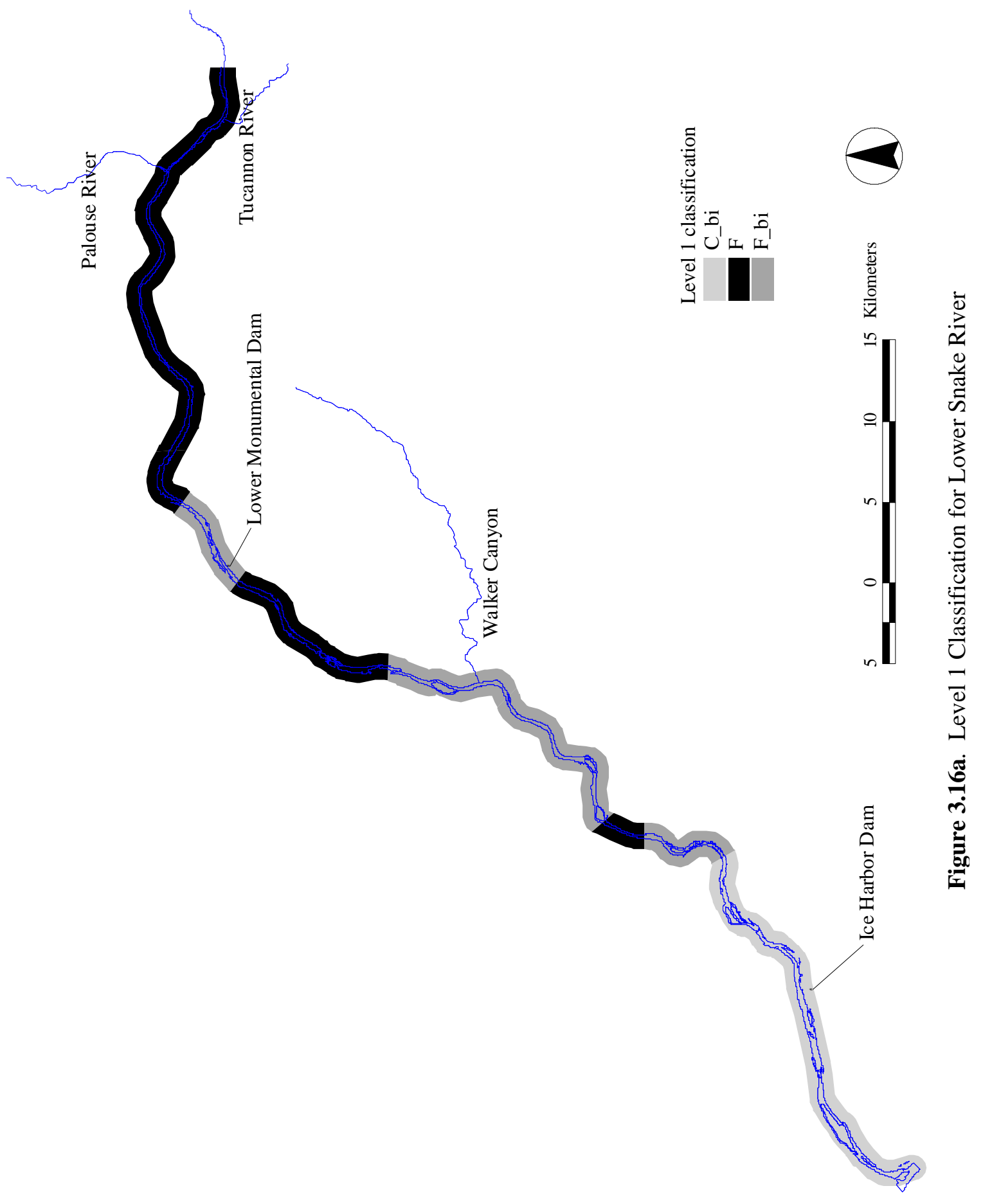




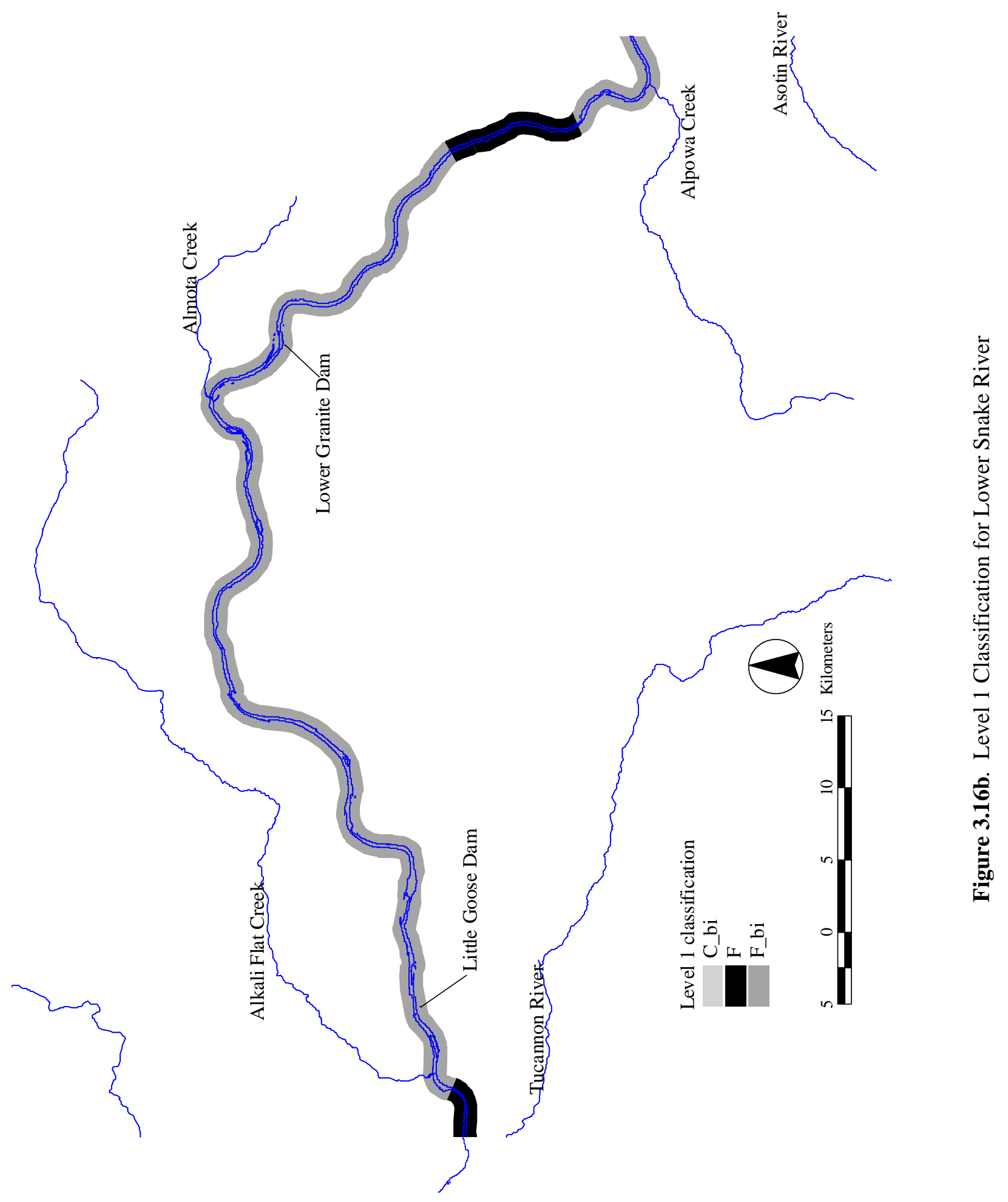



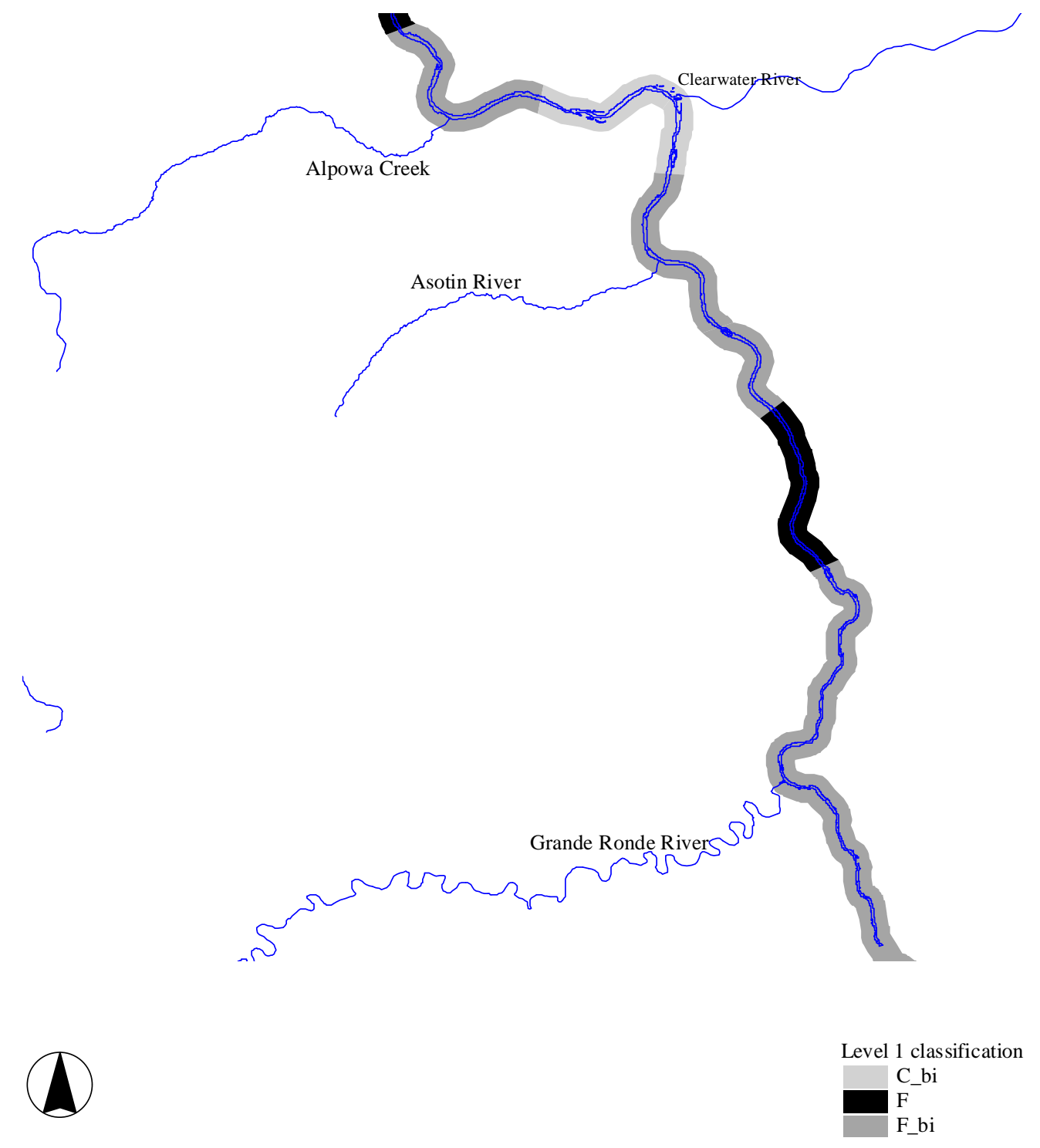

Figure 3.16c. Level 1 Classification for Lower Snake River 


\subsubsection{REACH-SCALE CLASSIFICATION (LEVEL 2)}

Although geomorphologically straight rivers such as the lower Snake River do not follow an actively sinuous path, many do possess a regularly meandering thalweg and filament of maximum velocity (Richards 1982; Thorne 1997). Results from the two-dimensional hydrodynamic modeling (MASS2) indicate a meandering thalweg (Figure 3.17) and filament of maximum velocity (Figure 3.18). These characteristics are closely related to vertical oscillations in bedforms (pool/riffle), which are in turn a dynamic response to non-uniform velocity, boundary shear stress, and sediment transport (Thorne 1997). These reach level characteristics were further evaluated through analysis of hydraulic geometry and longitudinal profiles in the reach-scale classification.

The level 2 classification resulted in 20 classes, including four within the level 1 class $\mathrm{C}_{\mathrm{bi}}$, eight within $\mathrm{F}_{\mathrm{bi}}$, and eight within $\mathrm{F}$ (Table 3.6). Again, most alluvial or partially alluvial reaches fall under the level 1 classes $\mathrm{C}_{\mathrm{bi}}$ and $\mathrm{F}_{\mathrm{bi}}$, while bedrock-confined and colluvial reaches are found mostly in the areas of level $1 \mathrm{~F}$ classifications. The level 2 class $\mathrm{F}_{\mathrm{bi}} 7$ represents the most common reach type, followed by F6, $\mathrm{C}_{\mathrm{bi}} 4$, and $\mathrm{F}_{\mathrm{bi}} 5$ (Table 3.7, Figure 3.19). Examples of Level 2 classifications for each cross section are depicted spatially on Figure 3.20, Figure 3.21, and Figure 3.22 according to level 1 class $\mathrm{C}_{\mathrm{bi}}$, $\mathrm{F}_{\mathrm{bi}}$, and F, respectively. On a dam-by-dam basis, the section between Little Goose Dam and Lower Granite Dam contains the largest number and percentage (100\%) of partially-alluvial reaches (Table 3.8). Similarly, the section upriver of Lower Granite Dam contains a considerable percentage of partially alluvial (62\%) and alluvial (20\%) reaches (Table 3.8), particularly near the confluence with the Clearwater River. Thus, the level 2 analysis provided additional detail on the location of alluvial reaches or areas with physical habitat characteristics important to production of salmon and steelhead (Stanford et al. 1996; Geist and Dauble 1998).

\subsubsection{ADDITIONAL HYDRAULIC AND GEOMORPHIC CHARACTERISTICS}

Mean velocity and mean depth for the $Q_{50}$ flow provide an indication of hydraulic conditions from cross section to cross section (e.g., Figure 3.23), including indications of pools and riffles. Unit stream power is a hydraulic parameter often used to describe a river's ability to transport sediment and perform geomorphic work (Bagnold 1977; Richards 1982; Thorne 1997). Stream power per unit bed area $(\omega)$ ranges from approximately 0 to $150 \mathrm{Watts} \mathrm{m}^{-2}$, oscillating in magnitude between river reaches (e.g., Figure 3.24). The oscillations in $\omega$ closely match the oscillations of the longitudinal bedform profile. When plotted with the water surface elevation at cross sections spaced $0.16 \mathrm{~km}$ apart, the longitudinal bedform profile is indicative of alternating pool/riffle channel morphology (e.g., Figure 3.25). Riffle spacing in straight alluvial rivers has been described as being fairly constant-between 5 to 7 channel widths apart (Leopold et al. 1964). Research on gravel- and cobble-bed rivers in England found a similar pattern, with riffle spacing ranging from 4 to 10 channel widths in length (Hey and Thorne 1986). In many segments of the study area, the riffle spacing ranges from 4 to 10 channel widths in length (e.g., Figure 3.25). This characteristic of non-uniform bed topography in a straight alluvial channel is indicative of sufficiently widely graded bed material such that selective entrainment, transport, and deposition produces systematic sorting of grain sizes between scour pools and riffle bars (Thorne 1997). 


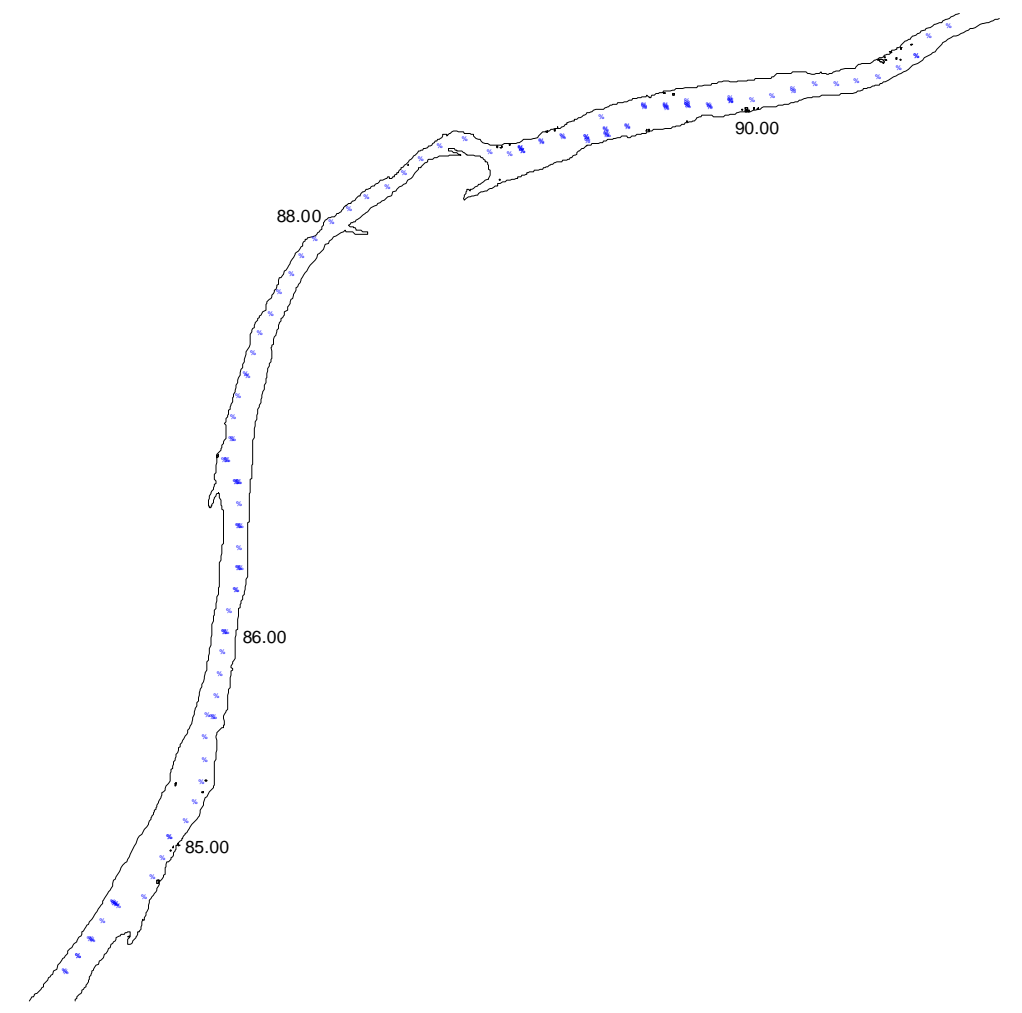

Figure 3.17. Example of Meandering Thalweg

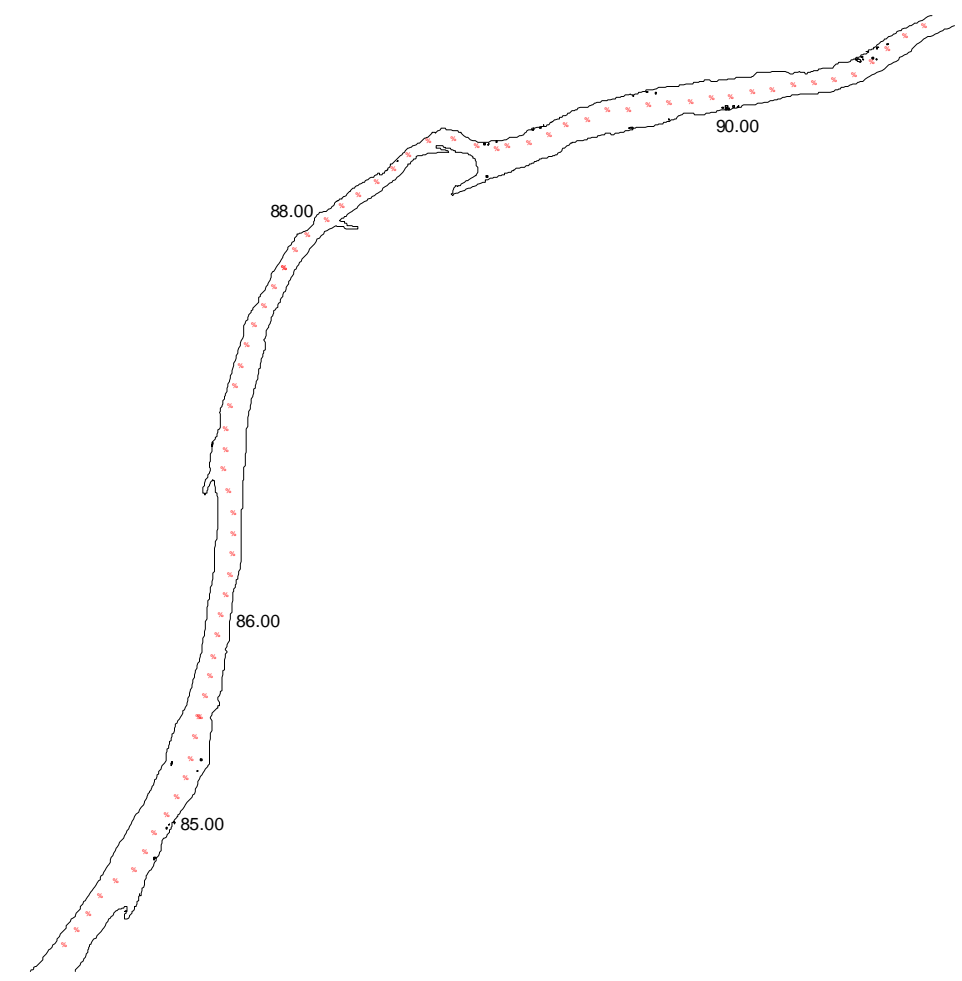

Figure 3.18. Example of Meandering Filament of Maximum Velocity 
Table 3.6. Level 2 Classification Descriptions by Level 1 Class

\begin{tabular}{|c|c|c|c|}
\hline Level 1 & Level 2 & $\begin{array}{l}\text { Level } 2 \\
\text { Code }\end{array}$ & Description \\
\hline \multirow[t]{5}{*}{ C_bi } & & & $\begin{array}{l}\text { The major lithology is dominated by unconsolidated sedimentary } \\
\text { rocks and deposits. The river channel is moderately confined by the } \\
\text { valley/canyon walls; indicating it is neither totally confined nor totally } \\
\text { unconfined. Bars and/or islands are present. }\end{array}$ \\
\hline & C_bi D34 F+ S+ ER+ & C_bi1 & $\begin{array}{l}\text { Cobble/gravel substrate, moderate to high } F \text {, moderate to high slope, } \\
\text { moderately entrenched }\end{array}$ \\
\hline & C_bi D34 F+ S+ ER- & C_bi2 & $\begin{array}{l}\text { Cobble/gravel substrate, moderate to high } F \text {, moderate to high slope, } \\
\text { entrenched }\end{array}$ \\
\hline & C_bi D34 F+ S- ER+ & C_bi3 & $\begin{array}{l}\text { Cobble/gravel substrate, moderate to high } F \text {, low slope, moderately } \\
\text { entrenched }\end{array}$ \\
\hline & C_bi D34 F+ S- ER- & C_bi4 & Cobble/gravel substrate, moderate to high $F$, low slope, entrenched \\
\hline \multirow[t]{9}{*}{ F_bi } & & & $\begin{array}{l}\text { The major lithology is a mix of unconsolidated sedimentary rocks/ } \\
\text { deposits and basalt bedrock. The river channel is moderately confined } \\
\text { by the valley/canyon walls; indicating it is neither totally confined nor } \\
\text { totally unconfined. Bars and/or islands are present. }\end{array}$ \\
\hline & F_bi D1 F+ S+ ER- & F_bil & $\begin{array}{l}\text { Bedrock channelbed, moderate to high } F \text {, moderate to high slope, } \\
\text { entrenched }\end{array}$ \\
\hline & F_bi D1 F+ S- ER+ & F_bi2 & $\begin{array}{l}\text { Bedrock channelbed, moderate to high } F \text {, low slope, moderately } \\
\text { entrenched }\end{array}$ \\
\hline & F_bi D1 F+ S- ER- & F_bi3 & Bedrock channelbed, moderate to high $F$, low slope, entrenched \\
\hline & F_bi D34 F+ S+ ER+ & F_bi4 & $\begin{array}{l}\text { Cobble/gravel substrate, moderate to high } F \text {, moderate to high slope, } \\
\text { moderately entrenched }\end{array}$ \\
\hline & F_bi D34 F+ S+ ER- & F_bi5 & $\begin{array}{l}\text { Cobble/gravel substrate, moderate to high } F \text {, moderate to high slope, } \\
\text { entrenched }\end{array}$ \\
\hline & F_bi D34 F+ S- ER+ & F_bi6 & $\begin{array}{l}\text { Cobble/gravel substrate, moderate to high } F \text {, low slope, moderately } \\
\text { entrenched }\end{array}$ \\
\hline & F_bi D34 F+ S- ER- & F_bi7 & Cobble/gravel substrate, moderate to high $F$, low slope, entrenched \\
\hline & F_bi D34 F- S- ER- & F_bi8 & Cobble/gravel substrate, low $F$, low slope, entrenched \\
\hline \multirow[t]{9}{*}{$\mathrm{F}$} & & & $\begin{array}{l}\text { The major lithology is a mix of unconsolidated sedimentary rocks/ } \\
\text { deposits and basalt bedrock. The river channel is highly confined by } \\
\text { the valley/canyon walls, and occupies almost the entire valley bottom. } \\
\text { Bars and/or islands are absent. }\end{array}$ \\
\hline & F D1 F+ S+ ER- & F1 & $\begin{array}{l}\text { Bedrock channelbed, moderate to high } F \text {, moderate to high slope, } \\
\text { entrenched }\end{array}$ \\
\hline & F D1 F+ S- ER+ & $\mathrm{F} 2$ & $\begin{array}{l}\text { Bedrock channelbed, moderate to high } F \text {, low slope, moderately } \\
\text { entrenched }\end{array}$ \\
\hline & F D1 F+ S- ER- & F3 & Bedrock channelbed, moderate to high $F$, low slope, entrenched \\
\hline & F D34 F+ S+ ER- & F4 & $\begin{array}{l}\text { Cobble/gravel substrate, moderate to high } F \text {, moderate to high slope, } \\
\text { entrenched }\end{array}$ \\
\hline & F D34 F+ S- ER+ & F5 & $\begin{array}{l}\text { Cobble/gravel substrate, moderate to high } F \text {, low slope, moderately } \\
\text { entrenched }\end{array}$ \\
\hline & F D34 F+ S- ER- & F6 & Cobble/gravel substrate, moderate to high $F$, low slope, entrenched \\
\hline & F D34 F- S- ER+ & F7 & Cobble/gravel substrate, low $F$, low slope, moderately entrenched \\
\hline & F D34 F- S- ER- & F8 & Cobble/gravel substrate, low $F$, low slope, entrenched \\
\hline
\end{tabular}


Table 3.7. Level 2 Classifications as Percent of Lower Snake River

\begin{tabular}{|l|c|}
\hline \multicolumn{1}{|c|}{ Level 2 Class } & \% of Total \\
\hline F_bi7 & 39.3 \\
\hline F6 & 18.9 \\
\hline C_bi4 & 10.7 \\
\hline F_bi5 & 8.6 \\
\hline F_bi6 & 8.0 \\
\hline F_bi4 & 2.7 \\
\hline F4 & 2.7 \\
\hline C_bi3 & 2.1 \\
\hline F1 & 1.8 \\
\hline F5 & 1.2 \\
\hline C_bi2 & 0.9 \\
\hline F3 & 0.6 \\
\hline C_bi1 & 0.6 \\
\hline F_bi1 & 0.3 \\
\hline F_bi2 & 0.3 \\
\hline F_bi3 & 0.3 \\
\hline F_bi8 & 0.3 \\
\hline F2 & 0.3 \\
\hline F7 & 0.3 \\
\hline F8 & 0.3 \\
\hline
\end{tabular}

Lower Snake River Level 2 Classification

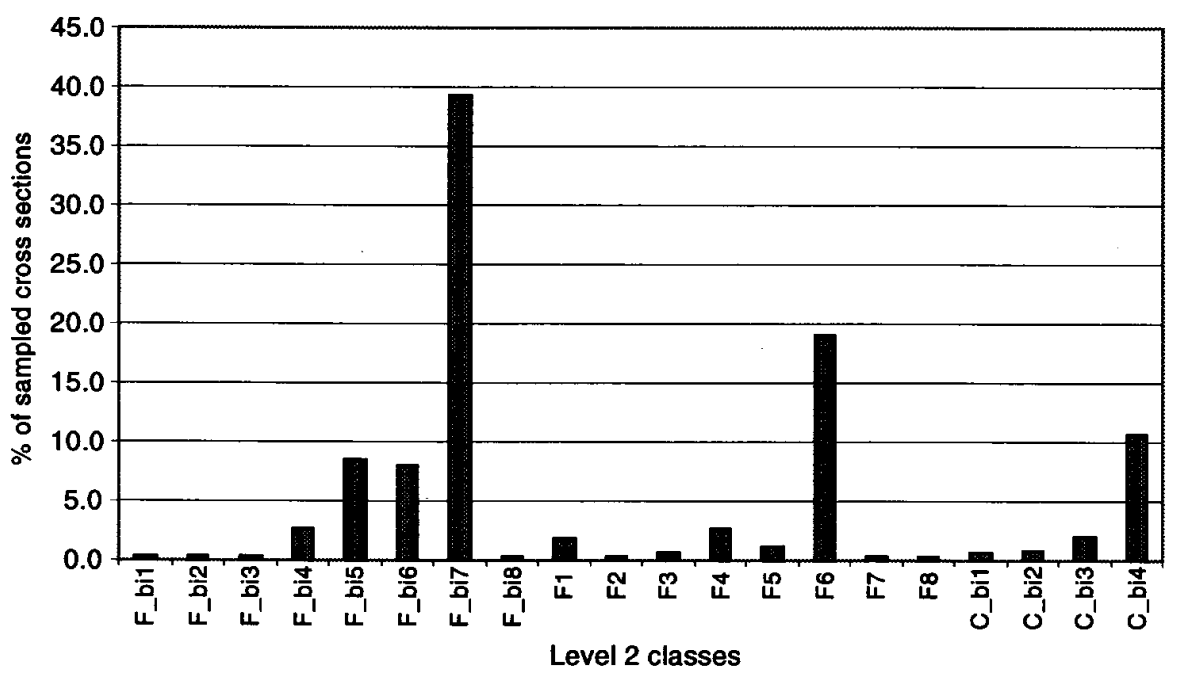

Figure 3.19. Level 2 Classifications as a Percent of Lower Snake River

Based on velocity:depth criteria given earlier, the pre-dam channel morphology and the $Q_{50}$ flow, the lower Snake River contained 4060 ha of pool habitat, 1792 ha. of run habitat, and 279 ha of riffle/rapid habitat (e.g., Figure 3.26). On a dam-by-dam basis, the section upriver of Lower Granite Dam contained 


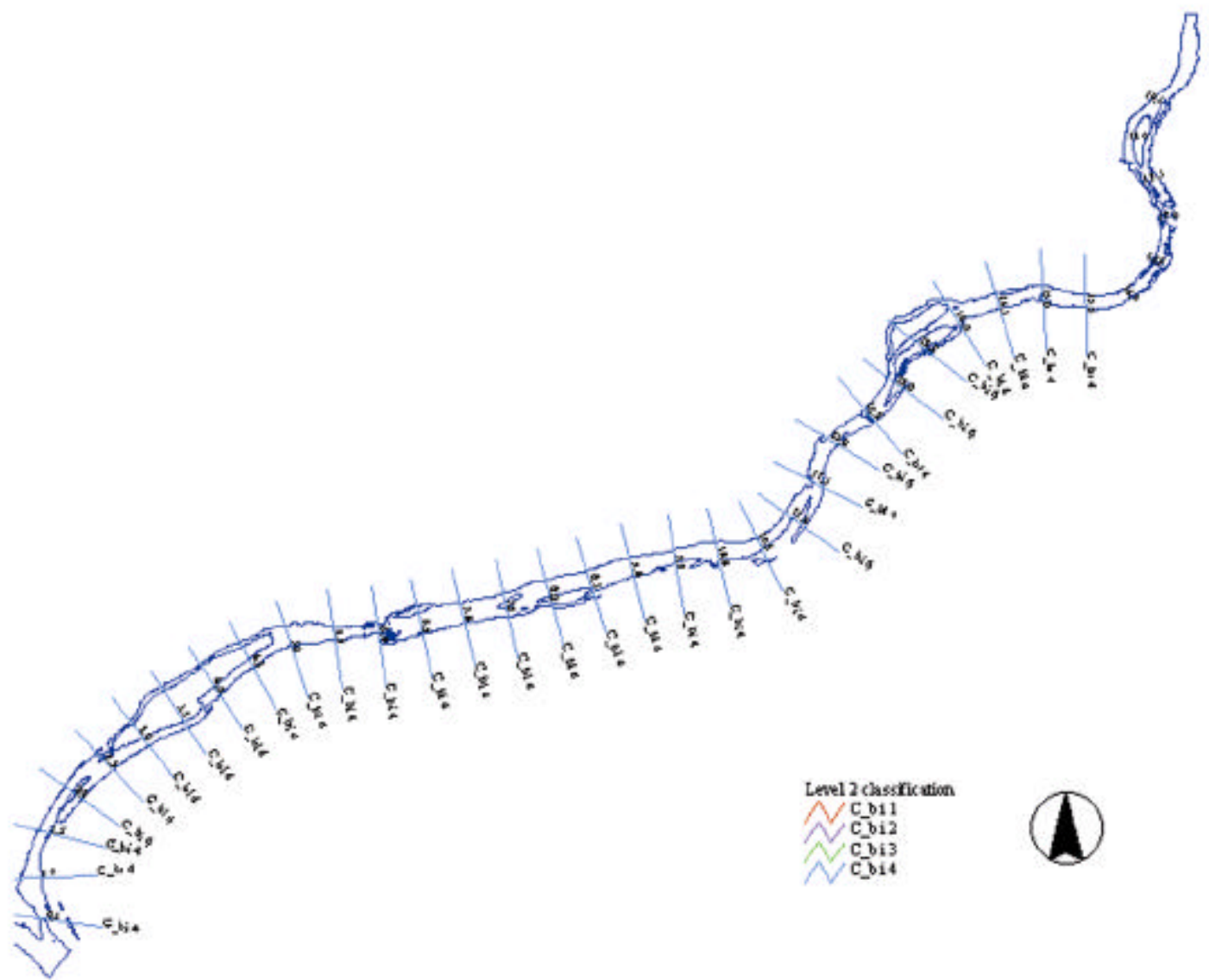

Figure 3.20. Level $2 \mathrm{C}_{\mathrm{bi}}$ Classification

the greatest percentage (70.5\%) of pool habitat (Table 3.9). The section between Little Goose Dam and Lower Granite Dam contained the greatest surface area of pool habitat ( 970 ha, 64\%), while the section between Lower Monumental Dam and Little Goose Dam was characterized by more riffle/rapid and run habitat (Table 3.9). These habitat features are generalized, as there are many variations within a particular habitat class (e.g., mid-channel pool, backwater pool). Even on the rivers where the criteria were calibrated, correct classification of habitat features is only moderately accurate. For example, in a study with extensive field-calibrated data, Jowett (1993) was only able to correctly classify $65 \%$ of the habitats. Additionally, the amount of pool habitat downriver of Ice Harbor Dam may be overestimated because the hydraulic model incorporates the reservoir elevation backwater effects near the Columbia River confluence caused by McNary Dam.

The cross-sectional form of natural channels are characteristically irregular and locally variable (Knighton 1984). The width to depth ratio $(F)$ is an important indicator of the distribution of available 


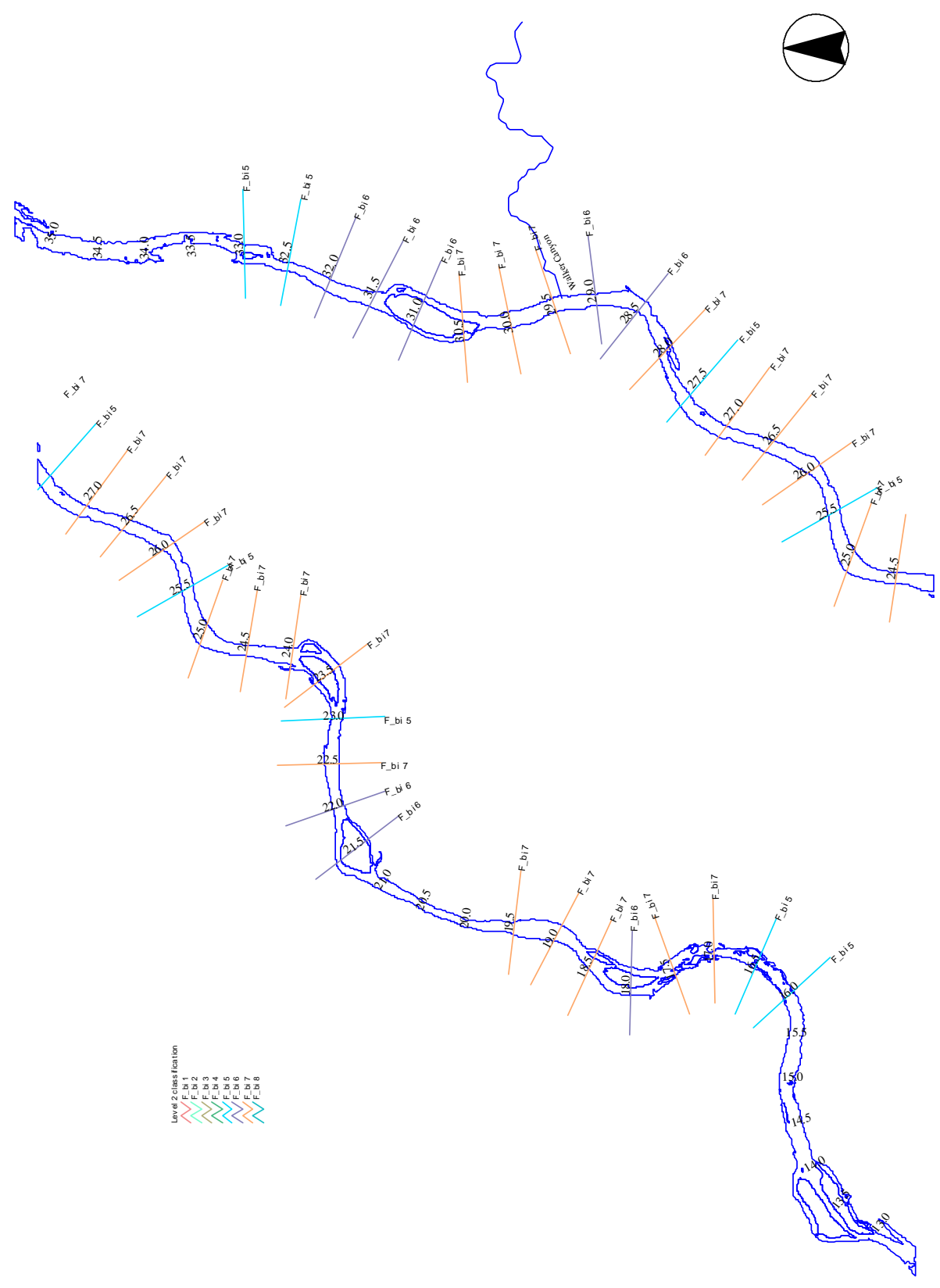

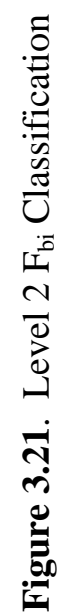




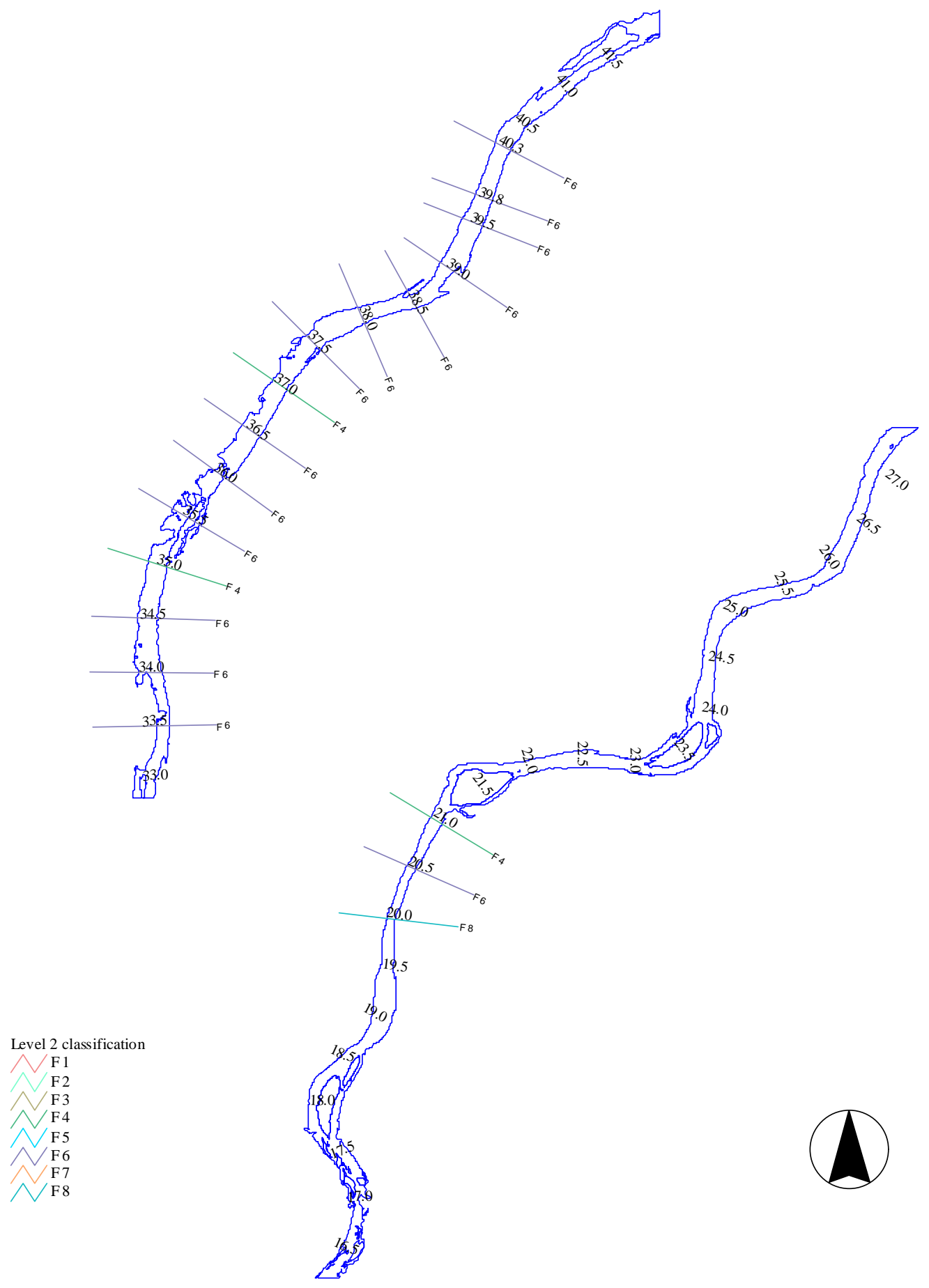

Figure 3.22. Level 2 F Classification 
Table 3.8. Level 2 Classifications as Percent of Lower Snake River Segments

\begin{tabular}{|l|c|c|c|c|c|}
\hline \multirow{2}{*}{ Level 2 Class } & \multicolumn{5}{|c|}{ Percent of Cross Sections in Each Segment } \\
\cline { 2 - 6 } & Mouth to IHR & IHR to LMN & LMN to LGO & LGO to LGR & Upriver of LGR \\
\hline C_bi 1 & 0 & 0 & 0 & 0 & 2.4 \\
\hline C_bi 2 & 0 & 0 & 0 & 0 & 3.5 \\
\hline C_bi 3 & 0 & 0 & 0 & 0 & 8.2 \\
\hline C_bi 4 & 100.0 & 18.8 & 0 & 0 & 5.9 \\
\hline F 1 & 0 & 0 & 8.3 & 0 & 1.2 \\
\hline F 2 & 0 & 0 & 1.7 & 0 & 0 \\
\hline F 3 & 0 & 0 & 3.3 & 0 & 0 \\
\hline F 4 & 0 & 4.7 & 10.0 & 0 & 0 \\
\hline F 5 & 0 & 0 & 5.0 & 0 & 0 \\
\hline F 6 & 0 & 21.9 & 45.0 & 0 & 12.9 \\
\hline F 7 & 0 & 0 & 1.7 & 0 & 0 \\
\hline F 8 & 0 & 1.6 & 0 & 0 & 0 \\
\hline F_bi 1 & 0 & 0 & 0 & 0 & 1.2 \\
\hline F_bi 2 & 0 & 0 & 0 & 0 & 1.2 \\
\hline F_bi 3 & 0 & 0 & 0 & 0 & 1.2 \\
\hline F_bi 4 & 0 & 0 & 0 & 6.7 & 2.4 \\
\hline F_bi 5 & 0 & 14.1 & 0 & 10.7 & 8.2 \\
\hline F_bi 6 & 0 & 12.5 & 1.7 & 14.7 & 5.9 \\
\hline F_bi 7 & 0 & 26.6 & 23.3 & 68.0 & 45.9 \\
\hline F_bi 8 & 0 & 0 & 0 & 0 & 0 \\
\hline Total & 100.0 & 100.0 & 100.0 & 100.0 & 100.0 \\
\hline
\end{tabular}

energy within a channel and the ability of various discharges to move sediment (Rosgen 1996).

Relatively high $F$ values such as those in the pre-dam lower Snake River (e.g., Figure 3.27) are often indicators of channel instability. This indication is based on the fact that channels with high $F$ values distribute energy and stress on the near bank region (Rosgen 1996). Whether a reach with high $F$ values is unstable depends on the erosion resistance characteristics of the bank material. Bank materials in the lower Snake River are predominantly highly erosion resistant.

The $d_{\max } / d$ parameter is an index of channel asymmetry. Channels with a $d_{\max } / d$ value approaching 1.0 are trapezoidal and regular in shape, while higher values indicate bedform diversity within a cross section. The cross sections in the pre-dam lower Snake River indicate variable $d_{\text {max }} / d$ values, with lower values roughly corresponding to lower $F$ values (e.g., Figure 3.27). The latter observation is indicative of narrow, deep river reaches that are trapezoidal in shape. A final parameter describing the variability in 

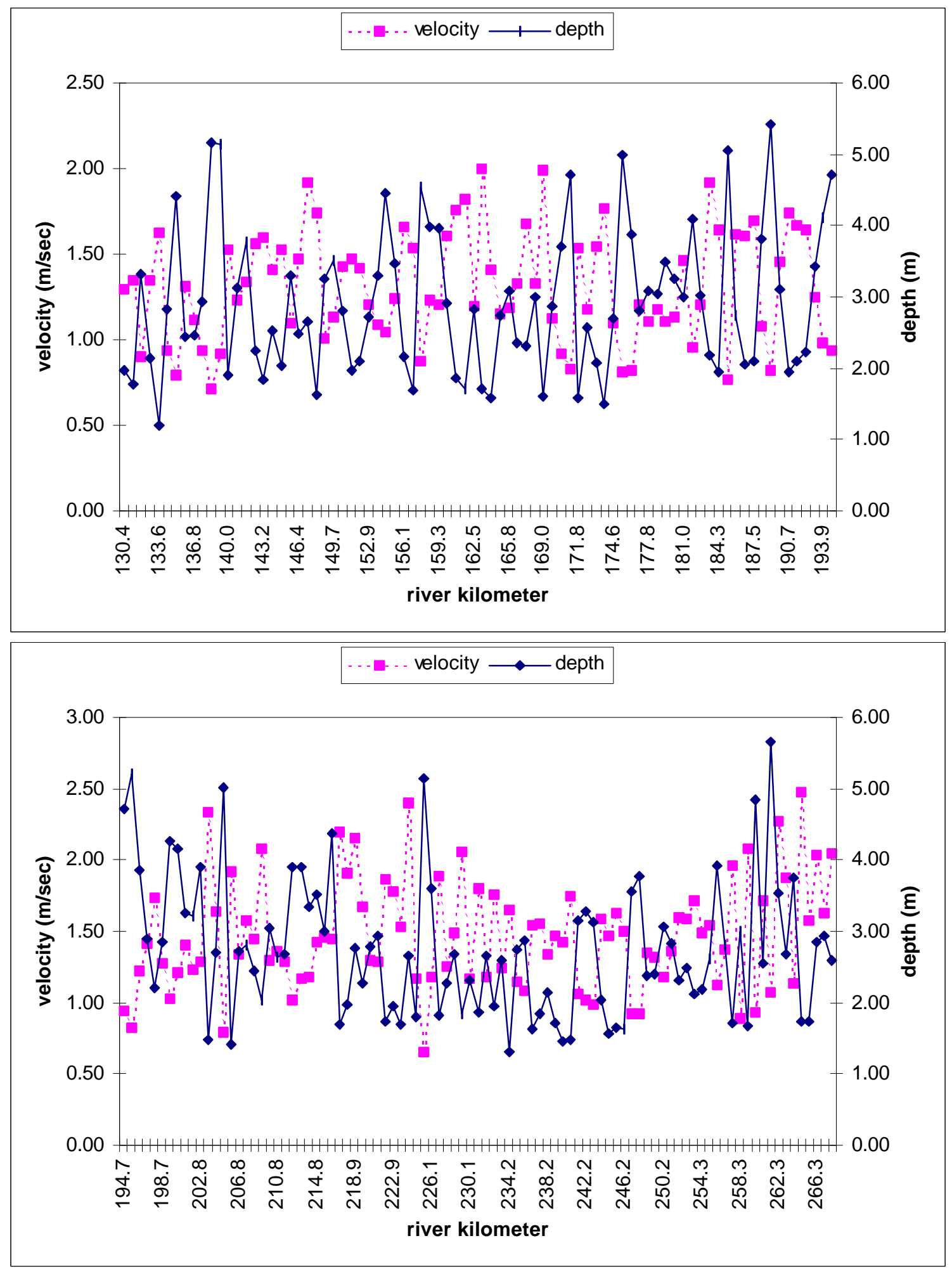

Figure 3.23. Mean Velocity and Mean Depth at Each Cross Section for $\mathrm{Q}_{50}$ Flow 

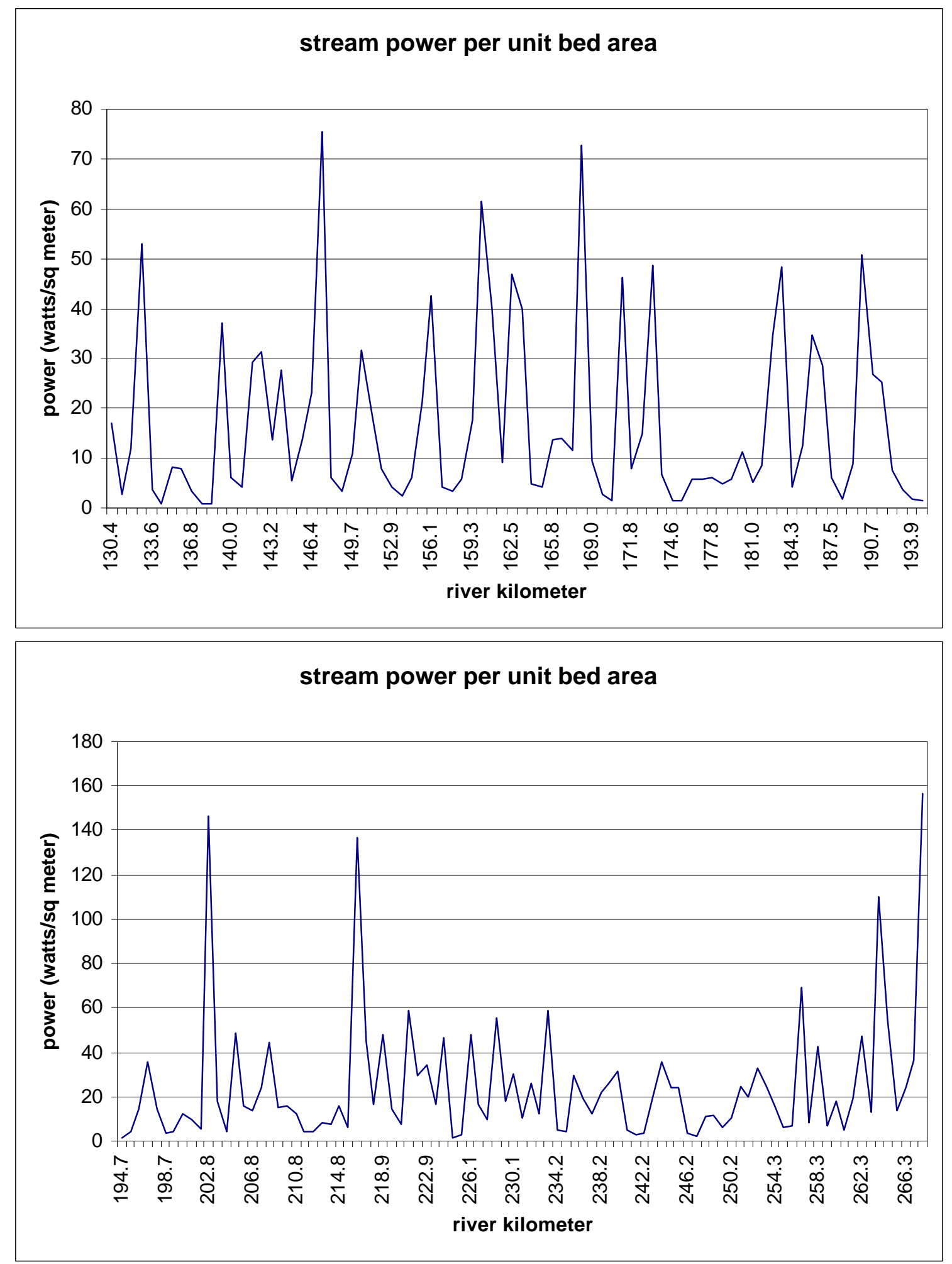

Figure 3.24. Stream Power at Each Cross Section for $\mathrm{Q}_{50}$ Flow 

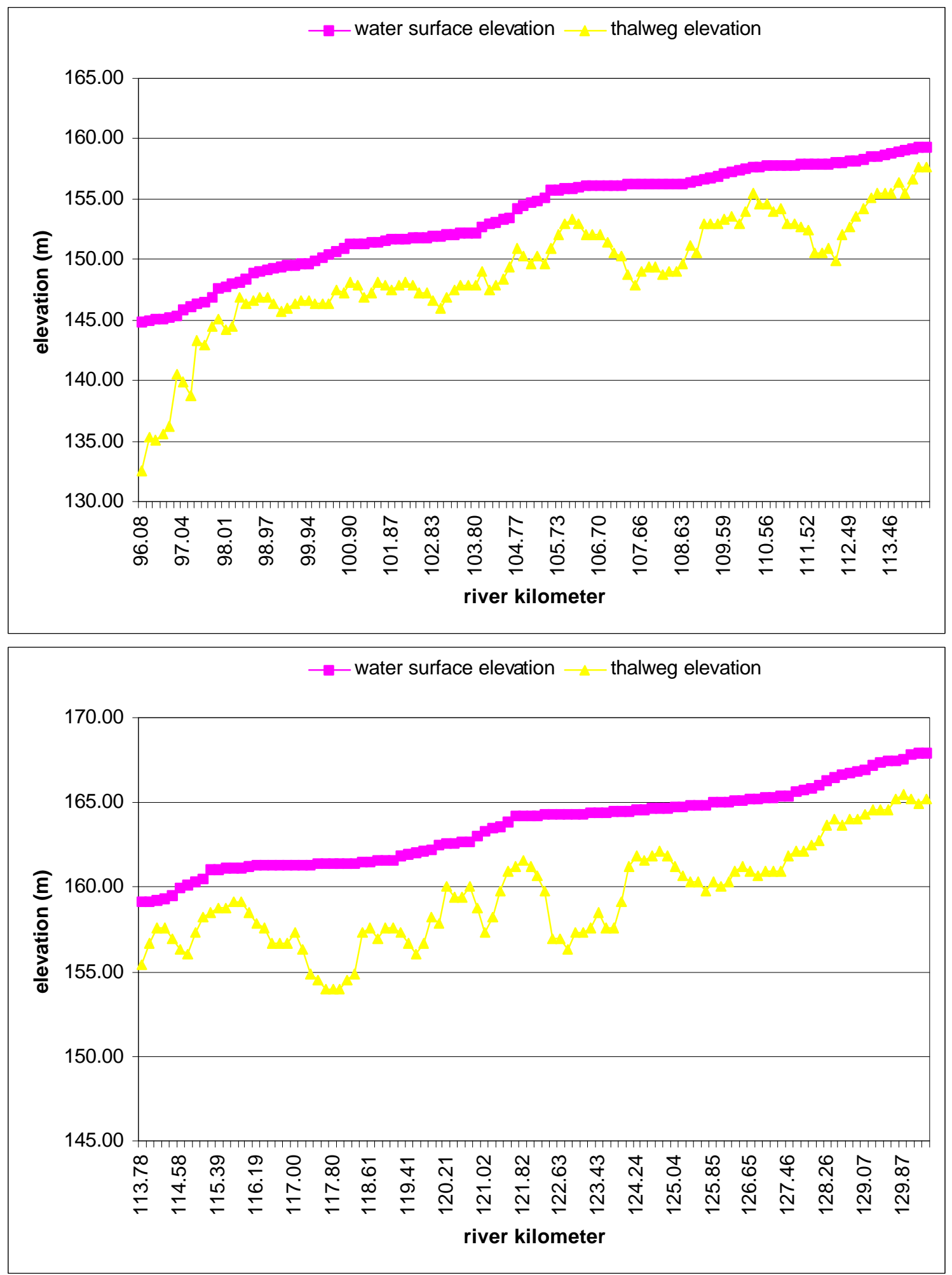

Figure 3.25. Longitudinal Profile of Water Surface and Thalweg Elevations for $\mathrm{Q}_{50}$ Flow 


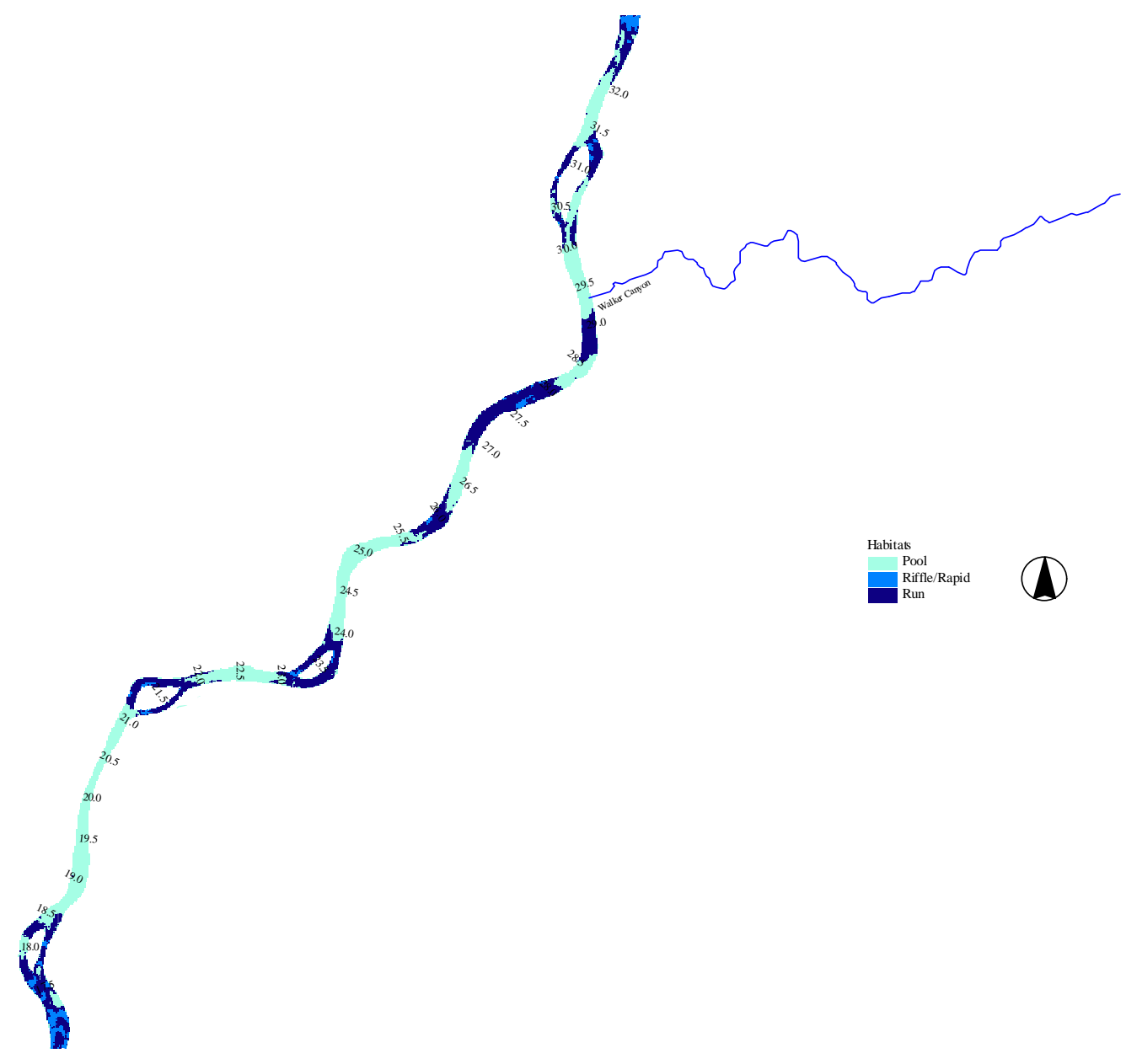

Figure 3.26. Pool, Run, and Riffle/Rapid Habitats

Table 3.9. Pool, Riffle/Rapid, Run Habitats of Lower Snake River Segments

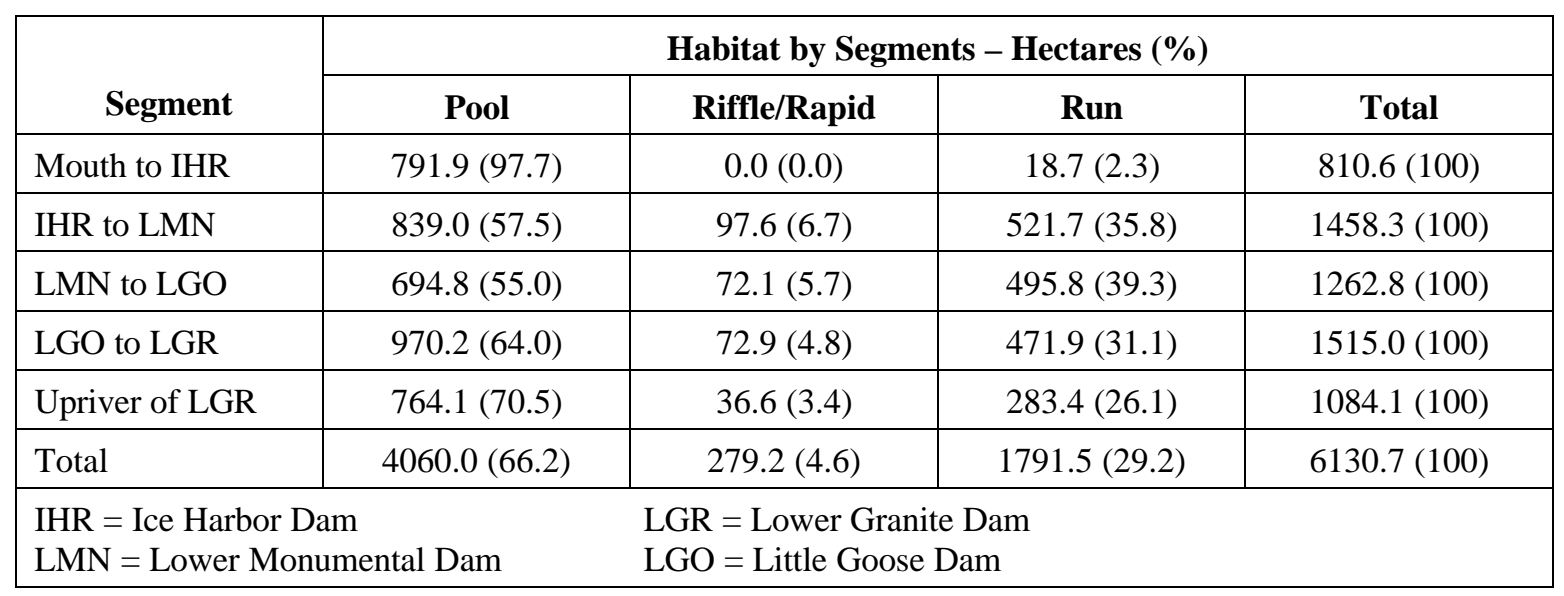



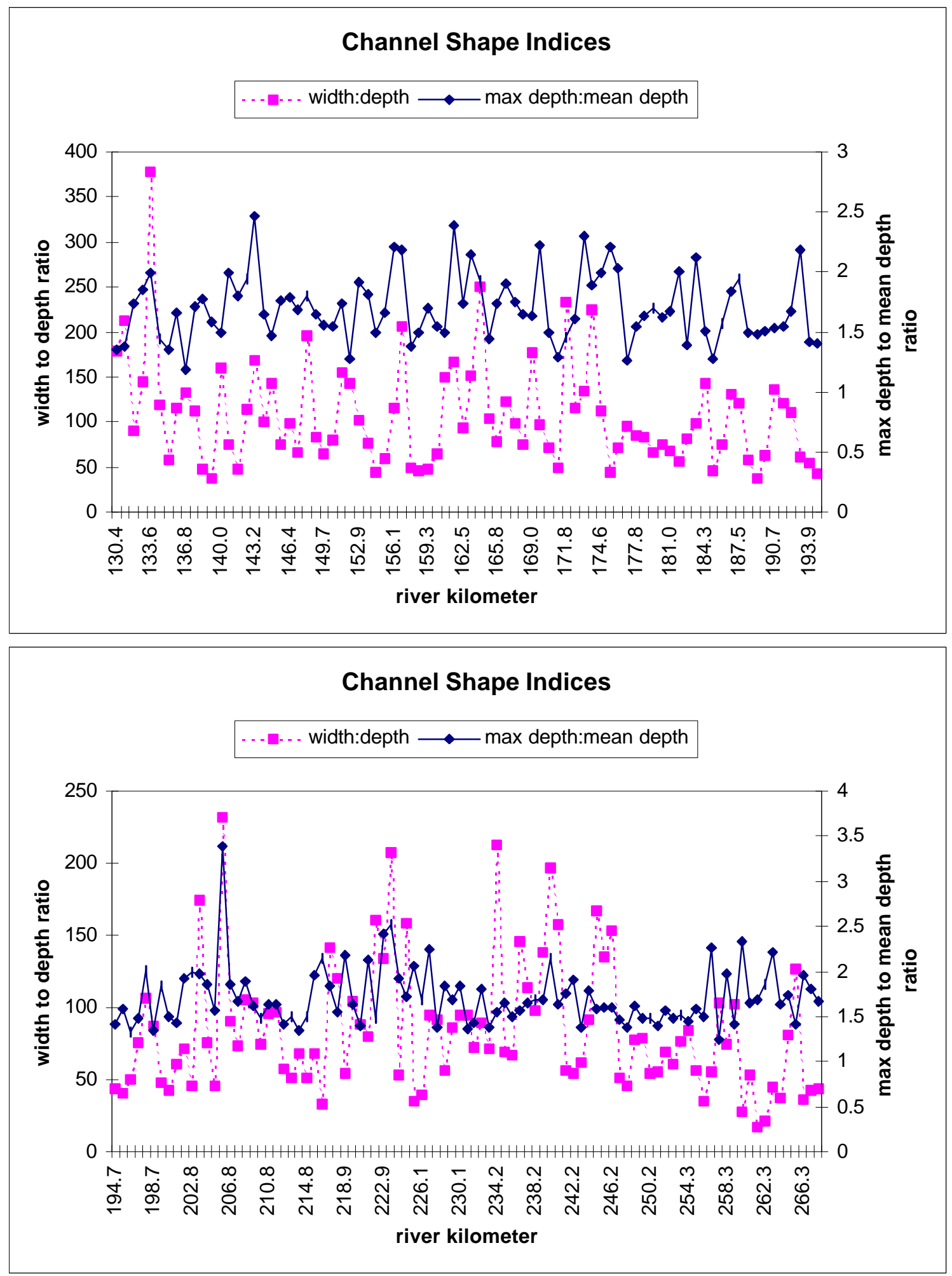

Figure 3.27. Channel Shape Indices at Each Cross Section for $\mathrm{Q}_{50}$ Flow 
natural channels is the planform characteristic of top width. Top width was calculated at each cross section based on the $Q_{50}$ flow. Top widths in the study area were highly variable from cross section to cross section (e.g., Figure 3.28), indicating planform channel asymmetry.

\subsubsection{GEOMORPHIC FEATURES AND SALMON PRODUCTION AREAS}

Redd density data are not available for fall chinook salmon spawning locations in the lower Snake River. However, such information has been well documented for the remainder of the Snake River during most of the hydro development period (see Chapter One for a full description) and provided a means to evaluate the relationship of various geomorphic features and spawning density in the Snake River.

When we applied the geomorphic spawning habitat model to the lower Snake River (from the mouth upriver to Tenmile Rapids at rkm 238.5-the upper limit of present day Lower Granite Dam reservoir), we estimated approximately $131 \mathrm{~km}$ of suitable spawning habitat may have been available during the prehydroelectric development period. This distance represents approximately 55\% of the lower Snake River. In contrast, historical accounts of fall chinook salmon spawning locations indicate that approximately $51 \mathrm{~km}$ or $21 \%$ of the lower Snake River was used as spawning habitat. Explaining the differences between these estimates is confounded by the quality and scarcity of historic spawning records for the lower Snake River. The historic records used were based on one account of estimated lineal river distance used for spawning, rather than repeated surveys, and therefore, may be an underestimate. In our analysis for the remainder of the mainstem Snake and Columbia rivers (see Chapter One) the geomorphic model predicted 40 to $50 \%$ less suitable spawning habitat than what was actually documented.

Historical accounts of fall chinook spawning include the area from rkm 11 to 30 (currently Ice Harbor Dam vicinity), from rkm 96 to 128 (upstream of the Palouse River) and near the confluence of the Clearwater River (Figure 3.29). The geomorphic model suggests that approximately $87 \%$ of the lineal river distance from Little Goose Dam upriver to Lower Granite Dam contains geomorphic characteristics conducive to fall chinook salmon spawning (Table 3.10; Figure 3.29), or the largest portion of potentially suitable fall chinook spawning habitat on a dam-by-dam basis.

The results of our geomorphic model were different than estimates of fall chinook spawning habitat based on traditional modeling characteristics of suitable depth, velocity, and substrate (USFWS 1999). The USFWS (1999) estimated that the section from Lower Monumental Dam to Little Goose Dam had the most potential spawning habitat under natural river drawdown (Table 3.11).

The geomorphic model helps refine where fall chinook salmon would spawn if the lower Snake River was returned to natural conditions; however, estimating surface area of a section of river used for spawning (microhabitat scale) requires the inclusion of finer scale geomorphic variables. This scaling discrepancy is evident in the Hanford Reach, where we have an extensive dataset of fine-scale fall chinook salmon spawning locations and density. For example, the geomorphic model predicts $66.5 \mathrm{~km}$ (67\%) of suitable spawning habitat in the Hanford Reach, while the surface area actually containing redds is only approximately $5 \%$. 

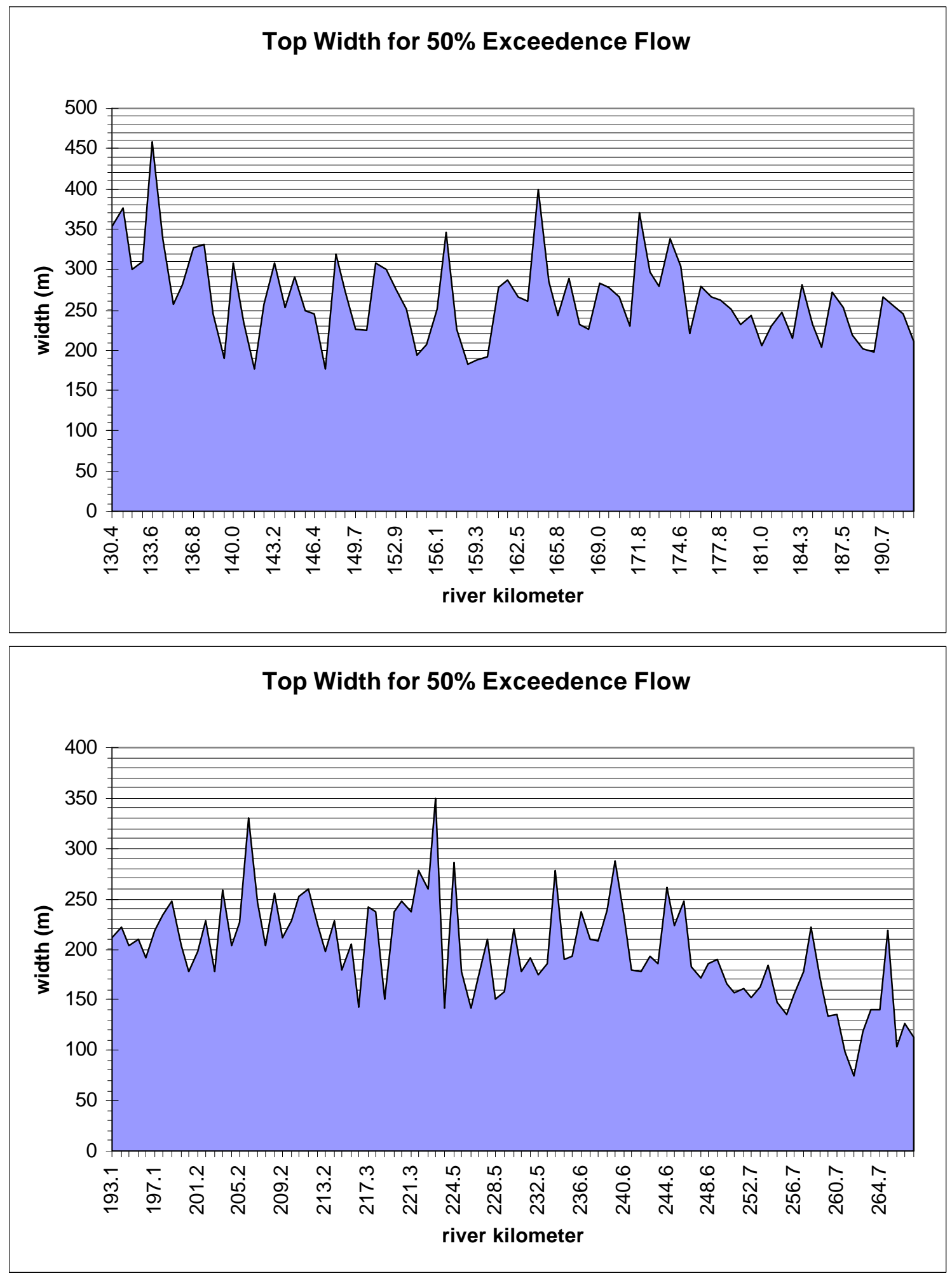

Figure 3.28. Top Width at Each Cross Section for $\mathrm{Q}_{50}$ Flow 


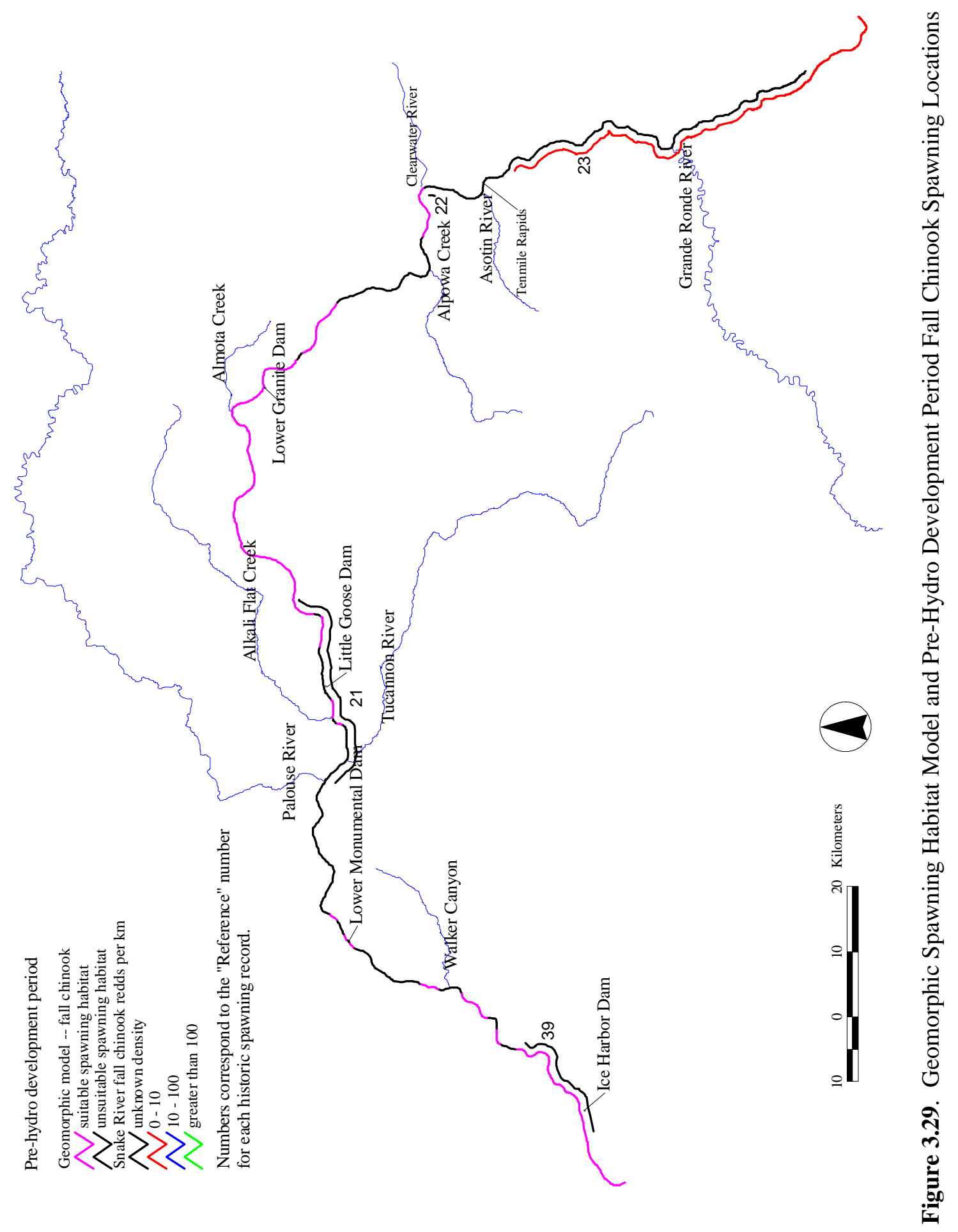


Table 3.10. Geomorphic Spawning Habitat Model Prediction for Lower Snake River Sections

\begin{tabular}{|l|c|c|c|}
\hline \multicolumn{1}{|c|}{ Section } & Section Length $(\mathbf{k m})$ & $\begin{array}{c}\text { Modeled Spawning } \\
\text { Suitability }(\mathbf{k m})\end{array}$ & \% of Section \\
\hline Mouth to IHR & 15.5 & 15.5 & 100 \\
\hline IHR to LMN & 50.5 & 28.5 & 56.4 \\
\hline LMN to LGO & 46.5 & 7.0 & 15.1 \\
\hline LGO to LGR & 59.5 & 52.0 & 87.4 \\
\hline LGR to 10 mi Rap. & 66.5 & 28.0 & 42.1 \\
\hline Lower Snake total & 238.5 & 131 & 54.9 \\
\hline $\begin{array}{l}\text { IHR = Ice Harbor Dam } \\
\text { LMN = Lower Monumental Dam }\end{array}$ & LGR = Lower Granite Dam \\
\hline
\end{tabular}

Table 3.11. Fall Chinook Spawning Habitat (\%) Under Natural River Conditions Based on Modeled Depths, Velocities, and Substrates (USFWS 1999)

\begin{tabular}{|l|c|c|c|c|c|c|}
\hline \multirow{2}{*}{ Suitability } & \multicolumn{5}{|c|}{ Location } & Mouth to \\
\cline { 2 - 7 } & IHR & IHR to LMN & LMN to LGO & LGO to LGR & $\begin{array}{c}\text { Upriver of } \\
\text { LGR }\end{array}$ & Total \\
\hline Not suitable & 63.7 & 57.2 & 39.2 & 79.9 & 92.3 & 66.6 \\
\hline Suitable & 32.9 & 31.0 & 40.7 & 12.2 & 2.8 & 23.5 \\
\hline Unknown & 3.5 & 11.8 & 20.2 & 7.9 & 4.9 & 10.3 \\
\hline
\end{tabular}

\subsubsection{FLOW REGIME AND SEDIMENT TRANSPORT}

Historical discharge records provided a means of comparing pre-major storage flow regimes with post-major storage flow regimes to determine if the latter has a geomorphic competency similar to the former. The annual maximum discharge, pre- and post-major storage, has not changed much (Figure 3.30). The mean of pre-major storage period annual maximum discharge is $5326 \mathrm{~m}^{3} \mathrm{~s}^{-1}$, while the mean for the post-major storage period is $4793 \mathrm{~m}^{3} \mathrm{~s}^{-1}$ (Table 3.12).

The geomorphic competency (erosional and depositional processes affecting morphological change) of a river is often determined by the bankfull flow (Hey 1997). The return period of bankfull flow for gravel-bed rivers is commonly determined as the 1 to 2-year flood, based on the annual maximum series (Leopold et al. 1964; Williams 1978). Because this method excludes lesser flood events above bed material transport thresholds, return periods based on partial duration series with a threshold discharge set at the initiation of bed material movement have been used as an alternative (Carling 1988; Hey and Heritage 1988; Hey 1997). This method yields a return period once every 0.9 years for bankfull flow in United Kingdom gravel-bed rivers (Hey and Heritage 1988; Hey 1997). To compare pre- and post-major storage geomorphic competency, we set the threshold value at the pre-major storage 1-year flood based on the annual maximum series. During the pre-major storage period this threshold discharge was equaled or exceeded $13 \%$ of the time. This percentage increased to $14 \%$ during the post-major storage period, 


\section{Annual peak Q (cfs)}

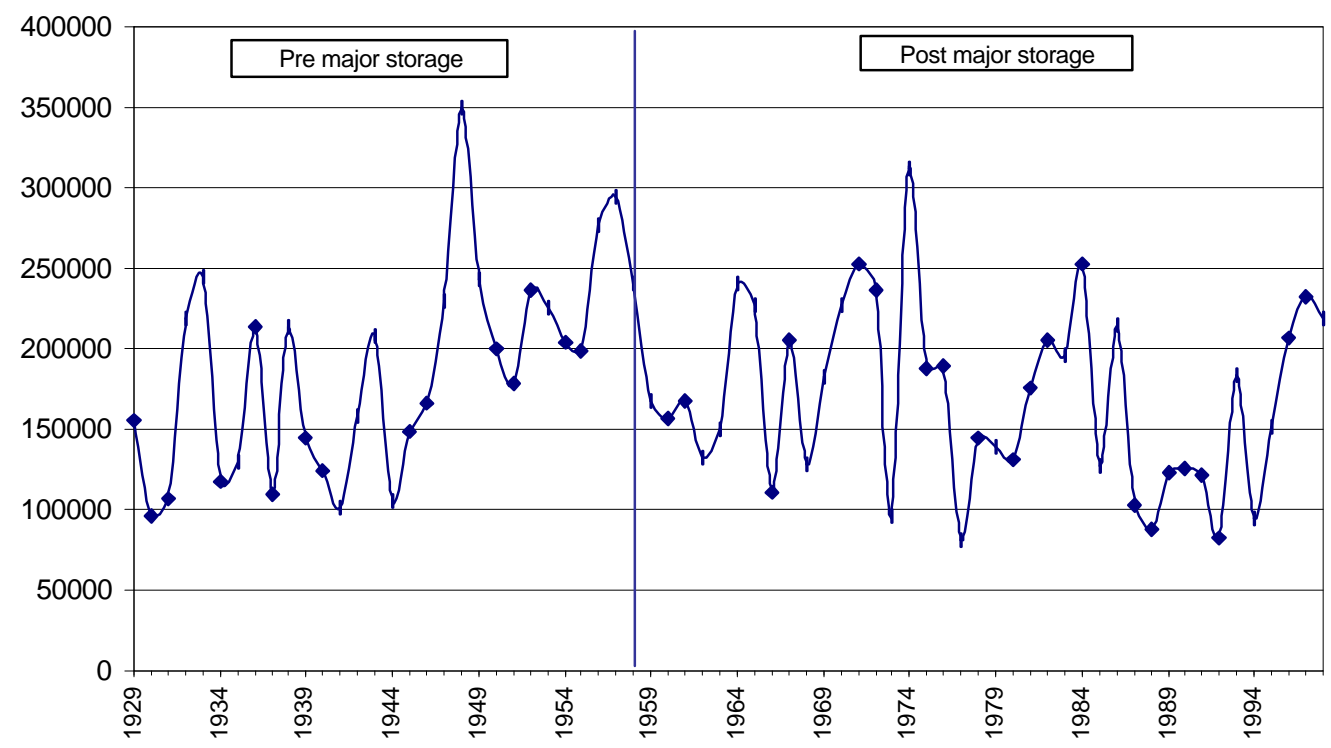

Figure 3.30. Lower Snake River Annual Peak Discharge, 1929 to 1998

Table 3.12. Lower Snake River Change in Annual Maximum Discharge for Pre- and Post-Major Storage Periods; Units are $\mathrm{m}^{3} \mathrm{~s}^{-1}(\mathrm{cfs})$

\begin{tabular}{|l|l|l|l|c|}
\hline & \multicolumn{1}{|c|}{ Pre-Major Storage } & \multicolumn{1}{|c|}{ Post-Major Storage } & \multicolumn{1}{c|}{ Change } & Post \% of Pre \\
\hline Mean & $5326(188,087)$ & $4793(169,257)$ & $533(18,830)$ & 90 \\
\hline Range & $7204(254,400)$ & $6556(231,539)$ & $647(22,861)$ & 91 \\
\hline Min & $2707(95,600)$ & $2290(80,882)$ & $417(14,718)$ & 85 \\
\hline Max & $9911(350,000)$ & $8847(312,421)$ & $1064(37,579)$ & 89 \\
\hline
\end{tabular}

suggesting no considerable difference in the geomorphic competency between the two periods. On an annual basis, the number of days the threshold discharge was equaled or exceeded ranged from 1 to 100 and 0 to 121 during the pre- and post-major storage periods, respectively.

The frequency of occurrence of the threshold discharge during any given year is particularly important in evaluating the time period expected for remobilization of the lower Snake River channelbed surface. The flow required for initiation of bedload transport can be much higher than typical criteria for rivers with a prolonged period of no sediment transport and containing infiltrated cohesive fine sediments that create a powerful cementation effect (Reid et al. 1997); conditions analogous to those in the impounded lower Snake River. During the first flood event following such conditions, bedload transport may be minimal, but will increase during subsequent flood events occurring with greater frequency (Reid et al. 1985). Therefore, the time period required for critical transport conditions in the lower Snake River will depend on the number of days the threshold discharge is equaled or exceeded in each year following drawdown. 
The geomorphic competency of the lower Snake River under the natural river drawdown scenario is also reflected in estimates of fine sediment transport. It was estimated that the majority of fine sediments currently accumulated in Lower Granite reservoir would be eroded and transorted within 5 years of removal of Lower Granite Dam (Figure 3.31; Hanrahan et al. 1998). In fact, most fine sediments would be removed in 2 years. These estimates are in agreement with observations made during the 1992 drawdown test of Lower Granite reservoir (USACE 1993) and with modeled estimates of sediment mobility in the lower Snake River as a whole (Richmond et al. 1999).

\section{Lower Granite Reservoir}

fine sediment removal estimate

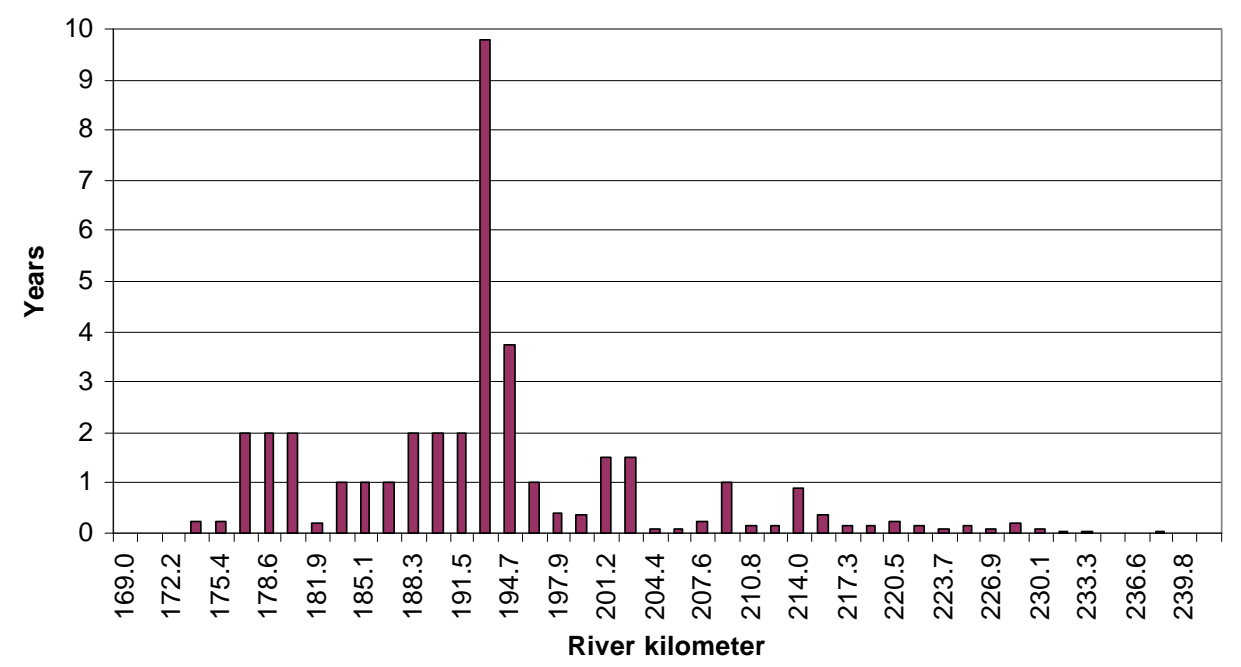

Figure 3.31. Estimated Time to Remove Fine Sediments from Lower Granite Reservoir Under Natural River Drawdown

\subsubsection{CONCLUSIONS}

Before impoundment, the lower Snake River exhibited heterogeneous characteristics ranging from those typical of alluvial reaches to those typical of bedrock-confined reaches in large rivers. In general, the pre-dam channel was a morphologically diverse, coarse-bedded, stable river possessing a meandering thalweg and classic pool-riffle longitudinal bedform profile.

The geomorphic model of fall chinook salmon spawning habitat suggests that several alluvial and partially alluvial reaches are particularly important areas with greatest potential for restoration. Two such areas within the lower Snake River are from the mouth upriver to approximately rkm 31, and near the confluence with the Clearwater River from rkm 215 to 229. One large contiguous section having geomorphic characteristics potentially suitable for fall chinook salmon spawning extends from approximately rkm 106 to 193, which includes much of Little Goose reservoir.

Analysis of historic and contemporary discharge records indicates that regulated flow regimes under natural river drawdown will be competent enough to maintain channel characteristics and riverine processes (e.g., channelbed mobilization). The time required before the realization of these characteristics 
and processes depends on many interrelated factors, including an initial 5- to 10-year period of erosion and transport of fine sediments accumulated in the reservoirs since dam construction. After the bulk of those fine sediments are removed, the regulated flow regime (particularly the annual maximum discharge) will be sufficient to mobilize the channelbed surface. The time required for the initiation of such processes depends on the annual flow regimes during the period following drawdown, particularly the frequency and duration of annual maximum discharge equaling or exceeding the pre-major storage period 1-year flood of $2707 \mathrm{~m}^{3} \mathrm{~s}^{-1}$.

\subsection{RECOMMENDATIONS}

The post-impoundment functioning of the lower Snake River could be regarded as more ecologically sustainable, as the functional and structural characteristics come closer to the alluvial river attributes described in Chapter Two. The rate and pathways for recovering these attributes in the lower Snake River depend on many interrelated factors, one of which is the physical template set by the river prior to impoundment (the pre-dam channel morphology described in this study). Other factors, yet to be addressed or resolved, governing the recovery of lower Snake River physical processes and characteristics include the following:

- post-impoundment management of the lower Snake River flow regime (magnitude, timing, duration, and frequency of base flows, bankfull flows, riparian flows, and floodplain flows)

- quantitative sediment budgets for the Snake River and its tributaries

- quantitative assessments of existing substrate composition in the lower Snake River

- quantitative assessments (e.g., spatial extent, composition, effects) of river channel alterations occurring between 1934 and completion of the first lower Snake River dam (1961), and from 1961 to present-day (e.g., channel/reservoir maintenance, dredging, in-channel disposal)

- quantitative assessments of the hydraulic and geomorphic effects from the dam structures remaining in place (e.g., navigation lock, spillway, powerhouse) after drawdown, existing shoreline protection, and velocity control structures.

These and other factors determine the rate and means by which the lower Snake River will evolve from its present condition to that described by the pre-dam channel morphology. This analysis of restoring mainstem habitats and riverine processes in the lower Snake River provides a starting point for continued analyses at a much finer scale.

\subsection{REFERENCES}

Bagnold, R.A. 1977. Bed load transport by natural rivers, Water Resources Research 13(2):303-312.

Baker, V.R., and R.C. Bunker. 1985. Cataclysmic late Pleistocene flooding from glacial Lake Missoula: A review, Quaternary Science Reviews 4:1-41. 
Becker, C.D. 1973. Food and growth parameters of juvenile chinook salmon, (Oncorhynchus tshawytscha) in central Columbia River. Fishery Bulletin 71(2):387-400.

Bennett, D.H., J.A. Chandler, and G. Chandler. 1991. Lower Granite Reservoir in-water disposal test: Results of the fishery, benthic and habitat monitoring program-Year 2 (1989). Completion report to U.S. Army Corp of Engineers, Walla Walla, Washington.

Bennett, D.H., J.A. Chandler, and L.K. Dunsmoor. 1990. Lower Granite Reservoir in-water disposal test: Results of the fishery, benthic and habitat monitoring program-Year 1 (1988). Completion report to U.S. Army Corp of Engineers, Walla Walla, Washington.

Bennett, D.H., T.J. Dresser, Jr., and T.S. Curet. 1992. Abundance of subyearling chinook salmon in Little Goose Reservoir Washington, spring 1991. Report to Corps of Engineers, Walla Walla, Washington.

Bjornn, T.C., and D.W. Reiser. 1991. Habitat requirements of salmonids in streams. Pages 83-138 in W.R. Meehan (ed.), Influences of forest and rangeland management on salmonid fishes and their habitats. American Fisheries Society Special Publication 19, Bethesda, Maryland.

Bovee, K.D. 1982. A guide to stream habitat analysis using the Instream Flow Incremental Methodology. Instream Flow Information Paper No. 12. Washington, D.C: U.S. Fish and Wildlife Service (FWS/OBS-82/26).

Brunke, M., and T. Gonser. 1997. The ecological significance of exchange processes between rivers and ground water. Freshwater Biology 37:1-33.

Burner, C.J. 1951. Characteristics of spawning nests of Columbia River salmon. Fishery Bulletin 52:95110.

Carling, P. 1988. The concept of dominant discharge applied to two gravel-bed streams in relation to channel stability thresholds, Earth Surface Processes and Landforms 13:355-367.

Chapman, D.W., D.E. Weitkamp, T.L. Welsh, and T.H. Schadt. 1986. Effects of river flow on the distributions of chinook Salmon redds. Transactions of the American Fisheries Society 115:537-547.

Chapman, D.W., D.E. Weitkamp, T.L. Welsh, and T.H. Schadt. 1983. Effects of minimum flow regimes on fall chinook spawning at Vernita Bar 1978-1982. Report to Grant County Public Utility District, Ephrata, Washington, by Don Chapman Consultants, McCall, Idaho, and Parametrix, Inc., Bellevue, Washington.

Chapman, W. M. 1943. The spawning of chinook salmon in the main Columbia river. Copeia (3):168170. 
Conner, W.P., A.P. Garcia, A.H. Connor, R.H. Taylor, C. Eaton, D. Steele, R. Bowen, and R.D. Nelle. 1994. Fall chinook salmon spawning habitat availability in the free-flowing reach of the Snake River. Pages 23-40 in D.W. Rondorf and K.F. Tiffan, editors. Identification of the spawning, rearing, and migratory requirements of fall chinook salmon in the Columbia River Basin - Annual Report 1993. Annual report to Bonneville Power Administration Report, Contract Number DE-AI79-91BP21708, Portland, Oregon.

Curet, T.S. 1993. Habitat use, food habits and the influence of predation of subyearling chinook salmon in Lower Granite and Little Goose Reservoirs, Washington. Masters Thesis. University of Idaho, Moscow, Idaho.

Dauble, D.D., and D.G. Watson. 1997. Status of fall chinook salmon populations in the mid-Columbia River, 1948-1992, North American Journal of Fisheries Management 17(2):283-300.

Dauble, D.D., R.H. Grey, and T.L. Page. 1980. Importance of insects and zooplankton in the diet of 0age chinook salmon (Oncorhynchus tshawytscha) in the central Columbia River. Northwest Science 52:253-258.

Dauble, D.D., T.L. Page, and R.W. Hanf, Jr. 1989. Spatial distribution of juvenile salmonids in the Hanford Reach, Columbia River. U.S. National Marine Fishery Service Fishery Bulletin 87:775-790.

Environmental Systems Research Institute. 1999. ArcInfo 7.2 Software and associated references.

Fulton, L.A. 1968. Spawning areas and abundance of chinook salmon (Oncorhynchus tshawytscha) in the Columbia River Basin--past and present. USFWS, Spec. Scie. Rep. No. 571.

Garland, R.D., D.W. Rondorf, K.F. Tiffan, and L.O. Key. In review. Subyearling fall chinook salmon use of shoreline riprap habitats in a reservoir of the Columbia River. North American Journal of Fisheries Management.

Geist, D.R. 1998. Redd site selection and spawning habitat use by fall chinook salmon. Doctoral dissertation. Oregon State University, Corvallis, Oregon.

Geist, D.R., and D.D. Dauble. 1998. Redd site selection and spawning habitat use by fall chinook salmon: the importance of geomorphic features in large rivers. Environmental Management 22(5):655669.

Ghanem, A.H., P.M. Steffler, F.E. Hicks, and C. Katopodis. 1995. Two-dimensional finite element modeling of aquatic habitats. Water Resources Engineering Report No. 95-S1, Department of Civil Engineering, University of Alberta, Edmonton, Alberta.

Hanrahan, T.P., D.A. Neitzel, M.C. Richmond, and K.A. Hoover. 1998. Assessment of drawdown from a geomorphic perspective using geographic information systems: Lower Snake River, Washington, Final Report to U.S. Army Corps of Engineers, Walla Walla District. 
Hanrahan, T.P., D.R. Geist, D.D. Dauble, and D.A. Neitzel. 1999. Pre-dam channel morphology of the lower Snake River, Draft Report to the U.S. Army Corps of Engineers, Walla Walla District.

Healey, M.C. 1991. Life history of chinook salmon. Pages 311-393 in C. Groot and L. Margolis, editors. Pacific salmon life histories. University of British Columbia Press, Vancouver, Canada.

Hey, R.D., and C. R. Thorne. 1986. Stable channels with mobile gravel beds, Journal of Hydraulic Engineering 112:671-689.

Hey, R. D., and G. L. Heritage. 1988 Dominant discharge in alluvial channels, in Proceedings of an International Conference on Fluvial Hydraulics, pp. 143-148, Budapest.

Hey, R.D. 1997. Stable river morphology, in Applied fluvial geomorphology for river engineering and management, edited by C.R. Thorne, R.D. Hey, and M.D. Newson, pp. 223-236, John Wiley and Sons, Chichester.

Huntington, C., W. Nehlsen, and J. Bowers. 1996. A survey of healthy native stocks of anadromous salmonids in the Pacific Northwest and California. Fisheries 21(3):6-14.

Independent Scientific Group. 1996. Return to the river: Restoration of salmonid fishes in the Columbia River ecosystem, Northwest Power Planning Council, Portland, Oregon. Draft.

Iwamoto, R.N., E.O. Salo, M.A. Madej, and R.L. McComas. 1978. Sediment and water quality: a review of the literature including a suggested approach for water quality criteria. U.S. Environmental Protection Agency, EPA 910/9-78-048, Seattle, Washington.

Johnson, B.R., and G.L. Raines. 1996. Digital representation of the Idaho state geologic map: A contribution to the Interior Columbia River Basin Ecosystem Management Project, Open File Report 95690, U.S. Geological Survey.

Jowett, I.G. 1993. A method for objectively identifying pool, run, and riffle habitats from physical measurements. New Zealand Journal of Marine and Freshwater Research 27:241-248.

Jowett, I.G. 1993. A method for objectively identifying pool, run, and riffle habitats from physical measurements, New Zealand Journal of Marine and Freshwater Research 27(2):241-248.

Kellerhals, R., and M. Church. 1989. The morphology of large rivers: characterization and management, edited by D.P. Dodge, pp. 31-48.

Kellerhals, R., M. Church, and D.I. Bray. 1976. Classification and analysis of river processes, Journal of the Hydraulics Division, Proceedings of the American Society of Civil Engineers, 102(HY7), 813-829. Key, L.O., J.A. Jackson, C.R. Sprague, and E.E. Kofoot. 1994a. Nearshore habitat use by subyearling chinook salmon in the Columbia and Snake Rivers. Pages 120-150 in Rondorf, D.W., and W.H. Miller, 
editors. Identification of the spawning, rearing, and migratory requirements of fall chinook salmon in the Columbia River Basin. 1992 Annual Report to Bonneville Power Administration, Contract DE-AI7991BP21708, Portland, Oregon.

Key, L.O., R.D. Garland, and E.E. Kofoot. 1994b. Nearshore habitat use by subyearling chinook salmon in the Columbia and Snake rivers. Pages 74-107 in Rondorf, D.W., and K.F. Tiffan, editors.

Identification of the spawning, rearing, and migratory requirements of fall chinook salmon in the Columbia River Basin. 1993 Annual Report to Bonneville Power Administration, Contract DE-AI7991BP21708, Portland, Oregon.

Key, L.O., R.D. Garland, and K. Kappenman. 1996. Nearshore habitat use by subyearling chinook salmon and non-native piscivores in the Columbia River. Pages 64-79 in D.W. Rondorf and K.F. Tiffan, editors. Identification of the spawning, rearing, and migratory requirements of fall chinook salmon in the Columbia River basin. Annual Report to the Bonneville Power Administration, contract DE-AI7991BP21708, Portland, Oregon.

Knighton, D. 1984. Fluvial forms and processes, 218 pp., Edward Arnold, New York.

Leclerc, M., A. Boudreault, J.A. Bechara, and G. Corfa. 1995. Two-dimensional hydrodynamic modeling: a neglected tool in the instream flow incremental methodology. Transactions of the American Fisheries Society 124(5):645-662.

Leopold, L.B., M.G. Wolman, and J.P. Miller. 1964. Fluvial processes in geomorphology, 522 pp., W.H. Freeman and Co., San Francisco, California.

Mains, E.M., and J.M. Smith. 1964. The distribution size, time, and current preferences of seaward migrant chinook salmon in the Columbia and Snake rivers. Washington State Department of Fisheries, Fisheries Research Papers 2(3):5-43, Olympia, Washington.

Milhous, R.T. 1979. The PHABSIM system for instream flow studies. Pages 440-446 in Proceedings of the 1979 summer computer simulation conference, Toronto, Ontario. Society for Computer Simulation, La Jolla, California.

Muir, W.D., and R.L. Emmett. 1988. Food habits of migrating salmonid smolts passing Bonneville dam in the Columbia River, 1984. Regulated Rivers: Research and Management 2:1-10.

Murphy, M.L., J. Heifetz, J.F. Thedinga, S.W. Johnson, and K.V. Koshi. 1989. Habitat utilization by juvenile Pacific salmon (Oncorhynchus) in the glacial Taku River, southeast Alaska. Canadian Journal of Fish and Aquatic Science 46:1677-1685.

National Marine Fisheries Service. 1998. A supplemental biological opinion to the March 2, 1995, Biological Opinion on operation of the Federal Columbia River Power System, National Marine Fisheries Service, Seattle, Washington. 
National Marine Fisheries Service. 1995. Biological Opinion on operation of the Federal Columbia River Power System, National Marine Fisheries Service, Seattle, Washington.

O’Connor, J. E. 1993. Hydrology, hydraulics, and geomorphology of the Bonneville Flood, Special paper 274, Geological Society of America, Boulder, Colorado.

Orth, D.K. 1983. Aquatic habitat measurements. Pages 61-84 in L.A. Nielsen and D.L. Johnson, editors. Fisheries Techniques. American Fisheries Society, Bethesda, Maryland.

Persat, H., and G.H. Copp. 1990. Electric fishing and point abundance sampling for the ichthyology of large rivers. Pages 197-209 in I.G. Cowx, editor. Developments in electric fishing. Blackwell Scientific Publications Ltd., Cambridge, Massachusetts.

Platts, W.S., W.F. Megahan, and G.W. Minshall. 1983. Methods for evaluating stream, riparian, and biotic conditions. General Technical Report INT-138 ed. U.S. Forest Service Intermountain Forest and Range Experiment Station, Ogden, Utah. 70 pp.

Raines, G.L., and B. R. Johnson. 1996. Digital representation of the Washington state geologic map: A contribution to the Interior Columbia River Basin Ecosystem Management Project, Open File Report 95684, U.S. Geological Survey.

Reid, I., J.C. Bathurst, P.A. Carling, D.E. Walling, and B.W. Webb. 1997. Sediment erosion, transport, and deposition, in Applied fluvial geomorphology for river engineering and management, edited by C.R. Thorne, R.D. Hey, and M.D. Newson, pp. 95-135, John Wiley and Sons, Chichester.

Reid, I., L.E. Frostick, and J.T. Layman. 1985. The incidence and nature of bedload transport during flood flows in coarse-grained alluvial channels, Earth Surface Processes and Landforms 10:33-44.

Reimers, P.E. 1973. The length of residence of juvenile fall chinook salmon in Sixes River, Oregon. Fish Commission of Oregon. Volume 4, Number 2.

Richards, K. 1982. Rivers: Form and process in alluvial channels, 361 pp., Methuen, London.

Richmond, M.C., and W.A. Perkins. 1999. A one-dimensional hydrodynamic and water quality model (MASS1), Pacific Northwest National Laboratory, Richland, Washington.

Richmond, M.C., W.A. Perkins, and C.L. Rakowski. 1999. Two-dimensional analysis of hydraulic conditions and sediment mobility in the lower Snake River for impounded and natural river conditions, Draft Report to the U.S. Army Corps of Engineers, Walla Walla District.

Rondorf, D.W., G.A. Gray, and R.B. Fairey. 1990. Feeding ecology of subyearling chinook salmon in riverine and reservoir habitats of the Columbia River. Transactions of the American Fisheries Society. 119:16-24. 
Rosgen, D.L. 1996. Applied river morphology, Wildland Hydrology, Pagosa Springs, Colorado.

SAS. 1996. SAS/STAT User's Guide, Release 6.12. SAS Institute, Inc., Cary, North Carolina.

Schuster, J.E., C.W. Gulick, S.P. Reidel, K.R. Fecht, and S. Zurenko. 1997. Geologic map of Washington: Southeast quadrant, Geologic Map GM-45, Washington State Department of Natural Resources, Division of Geology and Earth Resources, Olympia, Washington.

Sheer, M.B. 1999. An assessment of fall chinook (Oncorhynchus tschawytscha) spawning habitat for present and pre-impoundment river conditions in a section of the John Day reservoir, Columbia River. M.S. paper, Oregon State University, Corvallis, Oregon.

Stalnaker, C.B. 1979. The use of habitat preferenda for establishing flow regimes necessary for maintenance of fish habitat. Pages 321-337 in J.V. Ward and J.A. Stanford (eds.) The ecology of regulated streams. Plenum Publishing, New York.

Stanford, J.A, J.V. Ward, W.J. Liss, C.A. Frissell, R.N. Williams, J.A. Lichatowich, and C.C. Coutant. 1996. A general protocol for restoration of regulated rivers. Regulated Rivers: Research and Management 12:391-413

Steffler, P. 1997. Draft user manual - cdg2d Model - June 27, 1997. University of Alberta.

Swan, G.A. 1989. Chinook salmon spawning surveys in deep waters of a large, regulated river. Regulated Rivers: Research and Management 4:355-370.

Swan, G.A., E.M. Dawley, R.D. Ledgerwood, W.T. Norman, W.F. Cobb, and D.T. Hartman. 1988. Distribution and relative abundance of deep-water redds for spawning fall chinook salmon at selected study sites in the Hanford Reach of the Columbia River. NOAA, NMFS, Seattle, Washington.

Taylor, E.B. 1990. Environmental correlates of life-history variation in juvenile chinook salmon, Oncorhynchus tshawytscha (Walbaum). Journal of Fish Biology 37:1-17.

Thorne, C.R. 1997. Channel types and morphological classification, in Applied fluvial geomorphology for river engineering and management, edited by C.R. Thorne, R.D. Hey, and M.D. Newson, pp. 175-222, John Wiley and Sons, Chichester.

Titus, K., J.A. Mosher, and B.K. Williams. 1984. Chance-corrected classification for use in discriminant analysis: ecological applications. American Midland Naturalist 111:1-7.

U.S. Army Corps of Engineers. 1993. 1992 reservoir drawdown test, Lower Granite and Little Goose dams, Walla Walla District, U.S. Army Corps of Engineers, Walla Walla, Washington. 
U.S. Fish and Wildlife Service. 1999. Fish and Wildlife Coordination Act Report for the U.S. Army Corps of Engineers' Lower Snake River Juvenile Salmon Migration Feasibility Study, USFWS Upper Columbia River Basin Office, Columbia River Fisheries Program Office, and Idaho Fishery Resource Office.

U.S. Army Corps of Engineers. 1951. Fish and Wildlife in Columbia River Basin. Appendix L, p. 2509 -2746. in Columbia River and tributaries, Northwestern United States, vol VI, House Document No. 531. United States Government Printing Office, Washington, D.C. pp 2315-2746.

Vronskiy, B.B. 1972. Reproductive biology of the Kamchatka River chinook salmon [Oncorhynchus tshawytscha (Walbaum)]. Journal of Ichthyology 12:259-273.

Williams, G.P. 1978. Bank-full discharge of rivers, Water Resources Research 14(6):1141-1154.

Yu, S.L., and E.J. Peters. 1997. Use of Froude number to determine habitat selection by fish. Rivers. 6(1):10-18.

Zimmerman, M.A., and L.A. Rasmussen. 1981. Juvenile salmonid use of three Columbia River backwater areas proposed for subimpoundment. U.S. Fish and Wildlife Service, Ecological Services, Portland, Oregon. 


\section{EPILOGUE}

This study provided a systematic assessment of the extent and types of habitat modifications that have occurred to the mainstem Columbia and Snake rivers and identified strategies with greatest potential for restoring habitats and populations of concern. The general framework for our assessment was based on developing relationships between attributes of alluvial rivers important to salmon production and the controlling factors that create them. The conceptual approach was to analyze the extent to which normative river attributes can be achieved through modification of mainstem dam operations (e.g., reservoir drawdown, dam removal, flow management). Implicit to this approach was the assumption that those habitat attributes supporting healthy salmonid populations in the past have the capacity to do so following changes in operation of the hydroelectric system and in the hydraulic regime of the river.

The results of our study are highly applicable to regional discussions of restoration of mainstem river habitats in areas impacted from development and operation of the hydroelectric system. For example, we provide more detailed analysis of the potential risks/benefits and uncertainties of drawdown of mainstem reservoirs (e.g., John Day and the four lower Snake River reservoirs) than recently completed studies of hydropower system operations. In addition, our analysis provides a comprehensive view of the entire Columbia River basin and associated hydropower/water storage practices, rather than individual portions of the federal hydropower system.

The guidelines for this study included the provision that no new data were to be collected. The Battelle/USGS study team was successful in their approach because each entity had been involved for several years in research activities that allowed access to the basic information needed to meet the proposed objectives. Thus, the study team had access to or knowledge of various biological, physical, and historical data sets that could be readily incorporated into GIS. One major benefit was acquiring and capturing information contained in historical maps of the Columbia River basin. We also determined that water storage and release practices, and effects on water temperature and ecosystem dynamics, are a key feature of salmonid habitats.

Our analysis identified river reaches or mainstem habitats having the greatest potential for restoration of riverine processes. A parallel effort to this project, also conducted for the Council, involved assessing the genetic and population structure of Columbia River salmon and how this structure has been altered by hydroelectric development. Synthesizing the results from these two Council projects will allow BPA and regional fisheries managers to make decisions on restoration options based on habitat use - within the context of metapopulation theories. More detailed studies are also required to assess the relationship between production potential and other system-level influences (e.g., flow variables, population genetics, ecosystem processes, and hatchery management practices, including supplementation).

There is also a need to collect new data (e.g., detailed bathymetry and substrates) and to refine existing data sets to better account for key uncertainties in the rearing and spawning habitat models used in our analyses. For example, a reviewer suggested additional empirical data was needed to refine estimates that were "largely a function of spatial averaging and scaling-up of simplified habitat association functions." Incorporating refined data sets in the analysis would provide a greater understanding of how rearing habitat and changes in food availability are affected by changes in water 
level and the relative amount of reservoir habitat. Another reviewer proposed an intensive research effort to generate the empirical data necessary to provide a first-order analysis for all affected fish species and life stages. A logical next step would involve a further integration of the results of the habitat assessment and the drawdown scenario analyses (i.e., Chapters 1 and 3) into the restoration options presented in Chapter 2. Although beyond the scope of this effort, there is also a need to thoroughly examine the socioeconomic impacts or economic costs/benefits of the different restoration options. 


\section{APPENDIX A \\ SUMMARY OF FALL CHINOOK SALMON SPAWNING IN MAINSTEM COLUMBIA AND SNAKE RIVERS}

Reference number is for relating GIS data tables back to this source of descriptive information-all GIS data table records for this spawning data contain a reference number.

(A.) Pre-development and hydro-development period (pre 1910 to 1975)

\begin{tabular}{|c|c|c|c|c|}
\hline $\begin{array}{l}\text { Columbia } \\
\text { River km }\end{array}$ & Landmarks & Remarks & $\begin{array}{l}\text { Reference } \\
\text { Number }\end{array}$ & Reference \\
\hline $235-306$ & Bonneville Dam reservoir & $\begin{array}{l}\text { Not specific where in reservoirs } \\
\text { but indicated that they inundated } \\
\text { former spawning areas }\end{array}$ & 1 & $\begin{array}{l}\text { Various cites Fulton } \\
\text { (1968) }\end{array}$ \\
\hline $310-470$ & $\begin{array}{l}160 \text { km section of main- } \\
\text { stem below McNary Dam } \\
\text { (i.e., The Dalles and John } \\
\text { Day reservoirs) }\end{array}$ & $\begin{array}{l}\text { Evidence exists that a large popu- } \\
\text { lation of fall chinook salmon } \\
\text { spawned in this reach. }\end{array}$ & 2 & $\begin{array}{l}\text { Various cites in Fulton } \\
\text { (1968) }\end{array}$ \\
\hline$\sim 504-540$ & $\begin{array}{l}\text { Mouths of Walla Walla, } \\
\text { Snake, and Yakima (near } \\
\text { Bateman Island, Tri-Cities) } \\
\text { rivers }\end{array}$ & $\begin{array}{l}\text { Large number of salmon observed } \\
\text { drying in racks on shores by } \\
\text { Lewis and Clark. Report by } \\
\text { Gilbert and Evermann notes } \\
\text { spawning observed at the mouths } \\
\text { of Yakima and Snake rivers. }\end{array}$ & 3 & $\begin{array}{l}\text { DeSoto 1953; Gilbert and } \\
\text { Evermann } 1894\end{array}$ \\
\hline $558-635$ & Hanford Reach & $\begin{array}{l}\text { Entire Hanford Reach used for } \\
\text { spawning (see Dauble and } \\
\text { Watson's redd counts since } \\
\text { 1943). However, a noted fishing } \\
\text { place of Wanapum Indians was in } \\
\text { the vicinity of White Bluffs at the } \\
\text { lower end of Locke Island. }\end{array}$ & 4 & $\begin{array}{l}\text { Dauble and Watson } \\
\text { (1997); historic fishing } \\
\text { place based on testimony } \\
\text { of Johnny Buck as } \\
\text { recorded by the U.S. } \\
\text { Dept. of Interior, Office of } \\
\text { Indian Affairs (1942) }\end{array}$ \\
\hline $635-659$ & Priest Rapids to Beverly & $\begin{array}{l}45 \text { redds counted between } 1947- \\
1957\end{array}$ & 5 & Edson (1958a) \\
\hline $659-674$ & Beverly to Vantage & $\begin{array}{l}2140 \text { redds counted between } \\
1947-1957\end{array}$ & 6 & Edson (1958a) \\
\hline $674-706$ & Vantage to Crescent Bar & $\begin{array}{l}1941 \text { redds counted between } \\
1947-1957\end{array}$ & 7 & Edson (1958a) \\
\hline $706-725$ & $\begin{array}{l}\text { Crescent Bar to Rock } \\
\text { Island }\end{array}$ & $\begin{array}{l}277 \text { redds counted between } 1947- \\
1957\end{array}$ & 8 & Edson (1958a) \\
\hline $730-764$ & $\begin{array}{l}\text { Rock Island Dam to Rocky } \\
\text { Reach Dam }\end{array}$ & Limited spawning in 1956-57 & 9 & French and Wahle (1960) \\
\hline $764-830$ & $\begin{array}{l}\text { Rocky Reach to Wells } \\
\text { Dam }\end{array}$ & & 10 & Horner and Bjornn (1979) \\
\hline $830-878$ & $\begin{array}{l}\text { Wells Dam to Chief Joseph } \\
\text { Dam }\end{array}$ & & 11 & Horner and Bjornn (1979) \\
\hline $804-955$ & $\begin{array}{l}\text { Chelan River to Grand } \\
\text { Coulee Dam (note overlap } \\
\text { to interval above) }\end{array}$ & 102 redds counted in 1946 & 12 & Fish and Hanavan (1948) \\
\hline
\end{tabular}


(A.) Pre-development and hydro-development period (pre 1910 to 1975) (contd)

\begin{tabular}{|c|c|c|c|c|}
\hline $\begin{array}{l}\text { Columbia } \\
\text { River km }\end{array}$ & Landmarks & Remarks & $\begin{array}{l}\text { Reference } \\
\text { Number }\end{array}$ & Reference \\
\hline $\begin{array}{l}1093 \text { and } \\
1061\end{array}$ & $\begin{array}{l}\text { Daisy and Rogers Bar } \\
\text { (about } 32 \mathrm{~km} \text { and } 64 \mathrm{~km} \\
\text { below Kettle Falls) }\end{array}$ & $\begin{array}{l}\text { Spawning beds toward the right } \\
\text { side of the river. Indians were } \\
\text { observed spearing fish at Daisy } \\
\text { and Rogers Bar. Probably } \\
\text { included both summer and fall } \\
\text { runs. }\end{array}$ & 13 & $\begin{array}{l}\text { Gilbert and Evermann } \\
\text { (1894); Chapman (1943); } \\
\text { Fulton (1968) }\end{array}$ \\
\hline $1121-1125$ & $3.2 \mathrm{~km}$ below Kettle Falls & $\begin{array}{l}\text { Salmon formally spawned in the } \\
\text { vicinity of Kettle Falls as late as } \\
1878 \text { (Gilbert and Evermann). In } \\
1938, \sim 15-20 \% \text { of the total run of } \\
\text { fall chinook passing above Rock } \\
\text { Island Dam spawned in this area } \\
\text { (Chapman 1943). }\end{array}$ & 14 & $\begin{array}{l}\text { Gilbert and Evermann } \\
\text { (1894); Chapman (1943) } \\
\text { as cited in Fulton (1968) }\end{array}$ \\
\hline $\begin{array}{c}\text { Snake River } \\
\text { km }\end{array}$ & Landmarks & Remarks & $\begin{array}{l}\text { Reference } \\
\text { Number }\end{array}$ & Reference \\
\hline $11-30$ & Near Ice Harbor Dam & Unknown density & 39 & $\begin{array}{l}\text { BCF (1960) cited in } \\
\text { Chapman and Witty } \\
(1993)\end{array}$ \\
\hline $96-128$ & $\begin{array}{l}32 \mathrm{~km} \text { section upstream of } \\
\text { the Palouse River }\end{array}$ & $\begin{array}{l}\text { Scattered throughout mainstem } \\
\text { Snake, especially in this location. }\end{array}$ & 21 & Fulton (1968) \\
\hline$\sim 225$ & Near Lewiston/ Clarkston & $\begin{array}{l}\text { Scattered throughout mainstem } \\
\text { Snake, especially in this location. }\end{array}$ & 22 & Fulton (1968) \\
\hline $240-398$ & $\begin{array}{l}\text { Asotin, Washington to } \\
\text { Hells Canyon Dam, i.e., } \\
\text { Hells Canyon Reach }\end{array}$ & $\begin{array}{l}\text { Spawning on scattered riffle areas } \\
\text { (Fulton). Peak redd counts were } \\
568(\sim 3.6 \text { redds/km) in } 1969 \text { ( } 2 \\
\text { years after construction of Hells } \\
\text { Canyon Dam) (Irving and } \\
\text { Bjornn). "no value to salmon } \\
\text { because of the steep gradient and } \\
\text { bedrock" (Parkhurst) }\end{array}$ & 23 & $\begin{array}{l}\text { Fulton (1968); Irving and } \\
\text { Bjornn (1981); original } \\
\text { redd count data?; } \\
\text { Parkhurst (1950B) }\end{array}$ \\
\hline $398-440$ & $\begin{array}{l}\text { Hells Canyon Dam to } \\
\text { Oxbow Dam }\end{array}$ & $\begin{array}{l}\text { Peak redd counts in this section } \\
207 \text { ( } 5 \text { redds/km) } \\
\text { in } 1963 . \text { Around } 1965, \text { the } \\
\text { majority of salmon spawn in this } \\
\text { reach (Haas) }\end{array}$ & 24 & Haas (1965) \\
\hline $440-459$ & $\begin{array}{l}\text { Oxbow Dam to Brownlee } \\
\text { Dam }\end{array}$ & $\begin{array}{l}\text { Peak redd counts were } 24(1.3 \\
\text { redds } / \mathrm{km}) \text { in } 1958\end{array}$ & 25 & Haas (1965) \\
\hline $459-565$ & $\begin{array}{l}\text { Brownlee Dam to Weiser, } \\
\text { Idaho }\end{array}$ & $\begin{array}{l}\text { Scattered spawning and fishing } \\
\text { areas, especially near mouth of } \\
\text { Burnt River (Rkm 528) } \\
\text { (Evermann) }\end{array}$ & 26 & Evermann (1896) \\
\hline $565-683$ & $\begin{array}{l}\text { Weiser, Idaho to Marsing, } \\
\text { Idaho }\end{array}$ & $\begin{array}{l}\text { Scattered spawning and fishing } \\
\text { areas, especially near mouth of } \\
\text { Boise (Rkm 630) and Owyhee } \\
\text { (Rkm 632) rivers (Evermann). } \\
\text { Not prime spawning habitat by } \\
1942 \text { (Parkhurst). Peak redd } \\
\text { count was } 34 \text { (<1 redd/km) in } \\
1957 \text { (Haas) }\end{array}$ & 27 & $\begin{array}{l}\text { Evermann (1896); } \\
\text { Parkhurst (1950c); Haas } \\
(1965)\end{array}$ \\
\hline
\end{tabular}


(A.) Pre-development and hydro-development period (pre 1910 to 1975) (contd)

\begin{tabular}{|c|c|c|c|c|}
\hline $\begin{array}{l}\text { Columbia } \\
\text { River km }\end{array}$ & Landmarks & Remarks & $\begin{array}{l}\text { Reference } \\
\text { Number }\end{array}$ & Reference \\
\hline $683-737$ & $\begin{array}{l}\text { Marsing, Idaho to Swan } \\
\text { Falls Dam }\end{array}$ & $\begin{array}{l}\text { Good spawning area just } \\
\text { upstream of Walters Ferry (Rkm } \\
713 \text { ) in } 1942 \text {, with last good run } \\
1929 \text { or } 1930 \text { (Parkhurst); Highest } \\
\text { redd count during surveys } 1947 \text { to } \\
1962 \text { were in this section; peak } \\
\text { was } 3804 \text { redds (70 redds/km) in } \\
1947 \text { (Haas). Major spawning } \\
\text { area prior to } 1958 \text { (Irving and } \\
\text { Bjornn) }\end{array}$ & 28 & $\begin{array}{l}\text { Parkhurst (1950c); Haas } \\
\text { (1965); Irving and Bjornn } \\
\text { (1981) }\end{array}$ \\
\hline $737-792$ & $\begin{array}{l}\text { Swan Falls Dam to CJ } \\
\text { Strike Dam }\end{array}$ & $\begin{array}{l}\text { From Swan Falls to Grand View, } \\
\text { Idaho (Rkm 780), marginal } \\
\text { spawning habitat due to the steep } \\
\text { gradient and bedrock. Upstream } \\
\text { of Grand View the valley widens. }\end{array}$ & 29 & Parkhurst (1950c) \\
\hline $792-902$ & $\begin{array}{l}\text { CJ Strike Dam to Bliss } \\
\text { Dam }\end{array}$ & $\begin{array}{l}\text { Vicinity of Glen Ferry to King } \\
\text { Hill (Rkm 853-879) "there is said } \\
\text { to be some spawning" } \\
\text { (Evermann); Vicinity of Bliss } \\
\text { there is some spawning } \\
\text { (Parkhurst); "It is certain that they } \\
\text { (salmon) visit Glen's Ferry and } \\
\text { the stretch of stream between } \\
\text { there and a point } 2 \text { or } 3 \text { miles } \\
\text { above Upper Salmon Falls in } \\
\text { large numbers and spawn mainly } \\
\text { in the bed of the stream..." } \\
\text { (Gilbert and Evermann) }\end{array}$ & 30 & $\begin{array}{l}\text { Evermann (1896); } \\
\text { Parkhurst (1950c); Gilbert } \\
\text { and Evermann (1894) }\end{array}$ \\
\hline $902-939$ & $\begin{array}{l}\text { Bliss Dam to Upper } \\
\text { Salmon Falls Dam }\end{array}$ & $\begin{array}{l}\text { Immediately below Lower } \\
\text { Salmon Falls the river is not used } \\
\text { much for spawning (Evermann). } \\
\text { Spawning in considerable } \\
\text { numbers just downstream of } \\
\text { Upper Salmon Falls - "most } \\
\text { important spawning area in Snake } \\
\text { River" (Evermann) }\end{array}$ & 31 & Evermann (1896) \\
\hline $939-977$ & $\begin{array}{l}\text { Upper Salmon Fall Dam to } \\
\text { Auger Falls }\end{array}$ & $\begin{array}{l}\text { Salmon pass over Salmon Falls in } \\
\text { "considerable numbers" (Gilbert } \\
\text { and Evermann; Evermann). } \\
\text { Immediately below Auger Falls } \\
\text { (Rock Creek) was an important } \\
\text { spawning area in late 1800s } \\
\text { (Gilbert and Evermann; } \\
\text { Evermann) }\end{array}$ & 32 & $\begin{array}{l}\text { Gilbert and Evermann } \\
\text { (1894); Evermann (1896) }\end{array}$ \\
\hline $977-990$ & $\begin{array}{l}\text { Auger Falls to Shoshone } \\
\text { Falls Dam }\end{array}$ & $\begin{array}{l}\text { Not many fish made it over Auger } \\
\text { Falls but a few did (Evermann) }\end{array}$ & 33 & Evermann (1896) \\
\hline
\end{tabular}


(B) Post-hydro development period (>1975)

\begin{tabular}{|c|c|c|c|c|}
\hline $\begin{array}{l}\text { Columbia } \\
\text { River km } \\
\end{array}$ & Landmarks & Remarks & $\begin{array}{c}\text { Reference } \\
\text { Number }\end{array}$ & Reference \\
\hline 232 & $\begin{array}{l}\text { Ives Island and Hamilton } \\
\text { Slough, "tailrace" of } \\
\text { Bonneville Dam }\end{array}$ & Recently document spawning & 15 & Hymer (1997) \\
\hline 468 & Tailrace of McNary Dam & Pre-1979 & 16 & Horner and Bjornn (1979) \\
\hline $558-635$ & Hanford Reach & $\begin{array}{l}\text { Entire Hanford Reach used for } \\
\text { spawning (see Dauble and } \\
\text { Watson's redd counts since 1943). }\end{array}$ & 17 & $\begin{array}{l}\text { Dauble and Watson } \\
\text { (1997) }\end{array}$ \\
\hline $664-666$ & Wanapum tailrace & $\begin{array}{l}\text { Surveys in } 1989,1990, \text { and } 1991 \\
\text { found } 492,130, \text { and } 257 \text { redds }\end{array}$ & 18 & $\begin{array}{l}\text { Rogers et al. (1988); } \\
\text { Dauble, unpublished data }\end{array}$ \\
\hline 728 & & & 19 & Horner and Bjornn (1979) \\
\hline 828 & Wells Dam tailrace & 85 redds counted in 1990 & 20 & Giorgi (1992) \\
\hline $\begin{array}{c}\text { Snake River } \\
\text { km }\end{array}$ & Landmarks & Remarks & $\begin{array}{c}\text { Reference } \\
\text { Number }\end{array}$ & Reference \\
\hline 15 & Ice Harbor Dam tailrace & One redd in 1996 & 34 & Dauble et al. (in press) \\
\hline$\sim 66$ & $\begin{array}{l}\text { Lower Monumental Dam } \\
\text { tailrace }\end{array}$ & Eggs recovered in dredge spoils & 35 & Kenney (1992) \\
\hline 113 & Little Goose Dam tailrace & $\begin{array}{l}\text { Surveys } 1993-1997 \text { found } 4,4,4 \text {, } \\
\text { and } 1 \text { redds }\end{array}$ & 36 & Dauble et al. (1999) \\
\hline 172 & $\begin{array}{l}\text { Lower Granite Dam } \\
\text { tailrace }\end{array}$ & $\begin{array}{l}\text { Surveys } 1993-1997 \text { found } 14,5 \text {, } \\
0, \text { and } 0 \text { redds }\end{array}$ & 37 & Dauble et al. (1999) \\
\hline $240-398$ & $\begin{array}{l}\text { Asotin, Washington to } \\
\text { Hells Canyon Dam, i.e., } \\
\text { Hells Canyon Reach }\end{array}$ & $\begin{array}{l}\text { Spawning on scattered riffle areas } \\
\text { (Fulton). Peak redd counts were } \\
132 \text { (<1 redds/km) in } 1978 . \\
\text { Recent counts } 50-125 \text { (Garcia } \\
\text { et al.; Groves and Chandler). }\end{array}$ & 38 & $\begin{array}{l}\text { Fulton (1968); Garcia } \\
\text { et al. (1999); Groves and } \\
\text { Chandler }(1996,1999)\end{array}$ \\
\hline
\end{tabular}




\section{APPENDIX B NAMES AND ADDRESSES OF WORKSHOP PARTICIPANTS}

\begin{tabular}{|c|c|c|c|}
\hline Name & Organization & Phone Number & Email \\
\hline Chris Frissell & $\begin{array}{l}\text { Flathead Lake Biological } \\
\text { Station, University of } \\
\text { Montana }\end{array}$ & $406982-3301$ & frissell@selway.umt.edu \\
\hline John Pizzimenti & HARZA & $503244-6922$ & jpizziminti@harza.com \\
\hline $\begin{array}{l}\text { Billy Connor (unable to } \\
\text { participate in workshop) }\end{array}$ & $\begin{array}{l}\text { U.S. Fish and Wildlife } \\
\text { Service }\end{array}$ & $208476-7242$ & william_connor@fws.gov \\
\hline Jim Ruff & $\begin{array}{l}\text { Northwest Power } \\
\text { Planning Council } \\
\end{array}$ & $503222-5161$ & jruff@nwppc.org \\
\hline $\begin{array}{l}\text { Dave Bennett (unable to } \\
\text { participate in workshop) }\end{array}$ & University of Idaho & $208885-6337$ & dbennett@uidaho.edu \\
\hline $\begin{array}{l}\text { Allan Ruger (unable to } \\
\text { participate in workshop) }\end{array}$ & $\begin{array}{l}\text { Bonneville Power } \\
\text { Administration }\end{array}$ & $503230-5813$ & aw.ruger@bpa.gov \\
\hline Jim Anderson & University of Washington & $206543-4772$ & Jim.fish@washington.edu \\
\hline Phil Groves & Idaho Power Company & $208388-2597$ & pag3414@idahopower.com \\
\hline Steve Reidel & Battelle & $509376-9932$ & sp.reidel@pnl.gov \\
\hline Dennis Dauble & Battelle & $509376-3631$ & dd.dauble@pnl.gov \\
\hline David Geist & Battelle & $509372-0590$ & dr.geist@pnl.gov \\
\hline Tim Hanrahan & Battelle & $509376-0972$ & tim.hanrahan@pnl.gov \\
\hline Mindi Sheer & $\begin{array}{l}\text { U.S. Geological Survey, } \\
\text { Biological Resources } \\
\text { Division }\end{array}$ & $\begin{array}{l}509538-2299 \\
\times 252\end{array}$ & mindi_sheer@usgs.gov \\
\hline Dennis Rondorf & $\begin{array}{l}\text { U.S. Geological Survey, } \\
\text { Biological Resources } \\
\text { Division }\end{array}$ & $\begin{array}{l}509538-2299 \\
X 228\end{array}$ & dennis_rondorf@usgs.gov \\
\hline Jim Petersen & $\begin{array}{l}\text { U.S. Geological Survey, } \\
\text { Biological Resources } \\
\text { Division }\end{array}$ & $509538-2299$ X236 & jim_petersen@usgs.gov \\
\hline Mike Parsley & $\begin{array}{l}\text { U.S. Geological Survey, } \\
\text { Biological Resources } \\
\text { Division }\end{array}$ & $509538-2299 \times 247$ & michael_parsley@usgs.gov \\
\hline
\end{tabular}

B.1 


\section{APPENDIX C \\ SYNOPSIS OF RESTORATION OPTIONS AS PRESENTED BY INDIVIDUAL PARTICIPANTS}

The following list of actions was derived from comments made by individual participants. Presentation and discussion of these options occurred before final prioritization. Where possible, those options with a common theme were grouped together.

\section{Actions with Focus on Reservoir Drawdown and/or Dam Breaching:}

Action - Institute permanent drawdowns of or breach McNary Dam, in conjunction with engineering fixes, including restoration of the lower Yakima and Walla Walla rivers Discussion - This option provides incremental gains in all but flow.

Action - Draw down McNary, John Day, and the four Lower Snake River dams (focused in areas containing desirable physical characteristics) in concert with habitat creation (e.g., gravel bar/island complexes) and temporal flow management (mimic natural hydrograph).

Discussion - This option provides spatially complex channel morphology, but leads to huge risks and uncertainties in ecology and socioeconomics.

Action - Partially draw down selected dams in phases.

Discussion - If tailrace restoration could be made successful, the possibility exists of increasing the area of habitat by gradual drawdown over a number of years. The vision is to extend the free-flowing tailrace section as demonstrated spawning in the tailrace occurs. This gradual drawdown scheme allows for learning with drawdown. It does not run the risk of an immediate drawdown, which would produce a drastic change in the environment. The decadal length of this drawdown project assumes that spawning habitat expansion is most successful as an expansion of existing redds. In this manner, fish first establish spawning in the tailrace then extend the tailrace area by a gradual drawdown over years or decades. This is an alternative to the redd (field) of dreams approach, which proposes that if we build it, they will come (i.e., draw the reservoirs down and expect spawning to take place). Progressive drawdown would occur over a few feet a year and require monitoring tailraces for establishment of spawning habitat. Study areas for progressive drawdowns would include the 1) upper Hanford Reach and Priest Rapids Dam forebay, and 2) Bonneville Dam tailrace drawdown by releasing less water.

Action - Partially breach or draw down dams.

Discussion - This option is more politically practical than full breaching. Suggest using historical data and current knowledge of sedimentation patterns to identify candidate areas that may contain "geologic" areas that are acceptable to salmon. Using this initial cut, do some surveys to see if the areas meet the necessary geologic criteria. Then determine which options would restore the environment to a salmonfriendly habitat. This action would not exclude any other option for restoring the environment — the point is to first find areas and then "engineer" the solution to restore the area to a riverine environment. 
Action - Consider spill crest drawdown of McNary Dam, but only if major new spawning areas can be created at the mouth of Yakima and Snake rivers.

Action - Remove Priest Rapids Dam to expand the Hanford Reach production area. If this works, remove Wanapum Dam.

Action - Breach or draw down John Day Dam, and breach the four lower Snake River dams. Discussion - This would create possible production areas throughout John Day Reservoir (76 miles), the lower Snake River (107 miles), and the area above Asotin or the lower Hells Canyon Reach (40 miles). In effect, this would create a stretch of relatively uninterrupted Snake River (160 miles) habitat, which would/could possibly allow for or meet the criteria for fall chinook salmon production. There would be a gap of about 40 miles between the mouth of the Snake River and McNary Dam, but with possible spawning habitat available continuing below McNary Dam down to John Day Dam. Recolonization or reseeding of the John Day Reservoir would have a good chance of happening because of its location downstream of the Hanford Reach, in addition to a newly established lower Snake River population base. This action would reestablish the greatest linear distance of the attributes of alluvial river systems. Attributes that would be achieved include increased channel complexity, improved water quality (maybe temperature, too), and velocity. It might also result in some channel migration and a functional floodplain in some areas. There would be slightly more natural hydrographs (from the lack of dams). Also, tributary influence would affect the hydrograph more because of the lack of regulation in the mainstem. Two large patches of possible production areas might be created by these actions. It would provide connections between the lower Columbia River (John Day Reservoir) and the Hanford Reach populations, with the populations/production areas that may be established in the lower Snake River, and with the already free-flowing section on the Snake River (the Hells Canyon Reach)—in essence 200 miles of usable spawning/rearing habitat in the mainstem.

Action - Do a near-term test of drawdown at one or two dams. Possible locations include the following 1) breach the four lower Snake River dams, 2) draw down John Day Dam, 3) lower McNary Reservoir in stages, 4) breach Wanapum Dam, and 5) breach Priest Rapids Dam.

Discussion - Small "fixes" involving changes in the biotic environment, passage conditions, and flow operations will result in only incremental improvements and do not restore attributes of a river system.

Action - Breach the Hells Canyon Complex.

Discussion - Meets all criteria.

Actions - Draw down the John Day Reservoir to the spillway crest, breach McNary Dam, breach Wanapum Dam, breach the four lower Snake River dams, and breach the Hells Canyon Complex. Discussion - We need to restore riverine processes to the Snake River to restore ESA-listed stocks of fall chinook salmon. The "patch size" of these mainstem areas should be sufficient to expect a real change in population status. Collectively, these actions would provide more functional floodplains and groundwater/surface water flow pathways. They would lead to a more natural hydrograph that would lead to less flood control but less spilling (and reduced dissolved gas). It would provide connectivity to geologic conditions required for spawning/production and to existing seed populations. These actions 
would likely require hatchery supplementation to jump start populations in these new habitats. A question or uncertainty is whether this action would require some control of reservoirs upstream of the Hells Canyon Complex to improve temperature regimes.

Action - Conduct partial drawdowns of all reservoirs to restore riverine habitat in the upper reaches of reservoirs. Drawdown could be to spillway crest or between minimum operating pool (MOP) and spillway (SW) crest.

Discussion - It's doable. It shouldn't affect upstream passage because facilities could be modified. It should improve spawning and juvenile downstream passage, provide a functional floodplain, provide for mobilized channel surface in upper reaches, allow for

channel bed scour (but no fill), and improve complex channel morphology.

Action - Draw down McNary Reservoir with flow regulation and provide a barge canal through Wallula Gap to move river commerce between the McNary Reservoir and the Snake River.

Discussion - This action would restore channel bed scour/deposition in the Hanford Reach. Reduced hydropeaking would increase production areas by enhancing hyporheic flows (groundwater/surface water) in the lower end of the Hanford Reach. It would increase habitat utilization, scour out side channels, and get periodic channel bed scour/fill. It would approach a more natural hydrograph, and it would enhance production potential at the mouths of the Yakima and Snake rivers. Metapopulation expansion would occur into the lower Yakima, Walla Walla, and Snake rivers.

Action - Breach John Day Dam (eliminates barging).

Action - Institute experimental drawdowns at McNary Reservoir and The Dalles.

\section{Actions Related to Restoration of More Natural Flow and/or Temperature Regimes:}

Action - Manage the Hells Canyon Complex and upper Snake storage for normative flow/temperature/ water quality regime to the lower Snake River and through John Day Reservoir. This would be initiated with several "enhanced" spring flushing flow events (post breaching).

Action - Conduct an experimental evaluation of seasonal/annual and daily hydrograph normalization in the Hanford Reach (test for unintended enhancement of non-native fishes).

Action - Naturalize the hydrograph and reduce hydropeaking and fluctuating reservoir elevations (could operate dams within normal rule curves to increase floodplain).

Discussion - This option keeps reservoirs and physical facilities intact and provides a functional floodplain and natural variability in flows. If reservoir levels could be manipulated seasonally to restore floodplain, mobilize sediments, and restore riparian vegetation; this might increase invertebrate production and restore varying lengths of riparian habitat in upper reaches.

Action - Modify the outlet works at the Hells Canyon Complex to improve volume/temperature controls. 
Action - Improve habitats downstream of Bonneville Dam via tailrace improvements and natural flows through Bonneville Dam flow re-regulation.

Action - Evaluate groundwater effluent reaches.

\section{Actions that Specifically Linked Drawdown/Breaching with Changes in the Hydrograph:}

Action - Breach the four lower Snake River dams and John Day Dam to provide connectivity to metapopulations. At the same time, implement operational measures to restore a more normative hydrograph (natural variation in flows) and a more natural temperature regime conducive to spawning, incubation, emergence, rearing, and migration of salmon. Constrain hydropeaking operations, especially below Priest Rapid Dam (Hanford Reach) and below Bonneville Dam. This would entail reducing temperatures in the lower Snake River during summer/early fall period by selective withdrawal releases from either Dworshak Dam or Brownlee Dam or both. Also, implement system-wide gas abatement measures to help reduce total dissolved gas during higher spring flows.

Action - A combination of activities should be considered that include the following:

- temporal drawdown and flow management in the lower Snake River and at Dworshak Dam on the Clearwater River system, as well as modifying shoreline reservoir habitat to be more fall chinook "friendly"

- some form of adult and juvenile fish passage (could include a combination of flow management and passage) at the Hells Canyon Complex to allow for recolonization of historic habitats

- rehabilitation of historic habitat upstream of Brownlee Dam

- modification of flows from Hells Canyon Complex to improve survival and habitat downstream of Hells Canyon Dam in current habitat.

Discussion - The costs of implementation and restoration potential of current habitat are uncertain. Will the proposed measures improve juvenile downstream survival? This begs the question of maintaining or increasing or eliminating transportation.

Action - Lower the McNary Reservoir through drawdown and restore an annual hydrograph, with reduced power peaking. Restoration of an annual hydrograph might also include temperature adjusting flows from Grand Coulee Dam.

Discussion - This option basically extends a known productive area, the Hanford Reach, without some costs associated with complete dam removal. Alluvial processes/attributes in the Hanford Reach and the McNary Reservoir would be improved. Other benefits include increased adult spawning production, increased juvenile survival/growth, and connectivity to existing free-flow reach.

Action - Implement a partial experimental drawdown at Lower Granite and or Little Goose reservoirs, as well as at McNary Reservoir, to determine additional mainstem spawning and rearing habitat for fall chinook salmon, especially in tailraces or headwaters of reservoirs. At the same time, implement operational measures to restore a more normative hydrograph (natural variation in flows) and a more natural temperature regime conducive to spawning, incubation, emergence, rearing, and migration of salmon. Constrain hydropeaking operations, especially below Priest Rapid Dam (Hanford Reach) and 
below Bonneville Dam. This would entail reducing temperatures in the lower Snake River during summer/early fall period by selective withdrawal releases from either Dworshak Dam or Brownlee Dam or both.

\section{Actions Related to Protection or Enhancement of Existing Habitats:}

Action - Improve tailrace environments.

Discussion - We need to describe attributes in terms of "windows of opportunity" units for spawning that maximize the chance of survival to emergence. The principal temporal factors to consider must include temperature and flow patterns. Strictly speaking, water quality factors are of secondary importance to survival to emergence unless they are sub-optimum to a degree where they degrade survival chances from the optimum for any temperature or flow regime. We also need to consider the geomorphology, which has a temporal variation (e.g., year or decade) and involves shifting morphology that replenishes gravel beds making them suitable for redds. The tailrace habitat under a tailrace reparations program would then categorize an areal extent of the temperature/velocity/geomorphological intersection for each dam. Questions of seeding spawners in these habitats would be addressed from knowledge of naturally seeded (e.g., Bonneville Dam) tailraces.

Action - Institute a floodplain management program in the lower Columbia River. This would involve disinvestments/buyouts/regulation of development/dike renovations/highway and railroad relocation or reconstruction.

Action - Purchase easements/properties around critical areas to prevent degradation of existing quality habitat, e.g., the Hanford Reach. This may prevent further development that puts fish/habitat at risk.

Action - Make all breaching projects include considerations of land management overlays and active rehabilitation measures to remove or modify artificial constraints to channel development and floodplain function and any impediment to natural vegetation development.

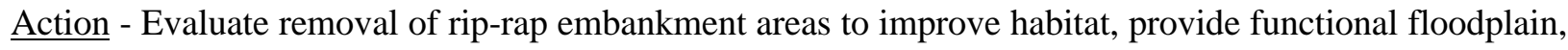
and periodic channel migration.

Action - Construct an artificial river channel between McNary and John Day dams. Discussion - This would open a new production area downstream of the now larger metapopulation (Hanford Reach and McNary Reservoir). This engineered solution would maintain production potential while allowing for movement of river commerce

\section{$\underline{\text { Actions Related to Altering Tributary Flows }}$}

Action - Draw down tributary reservoirs.

Discussion - Establish tributary reservoirs to improve flows to mimic natural flows and possibly improve habitat at the river confluence. 
Action - Improve tributary flows (not mainstem) to improve spring chinook/steelhead habitat. This by itself will improve habitat in mainstem, especially at the mouth of tributaries.

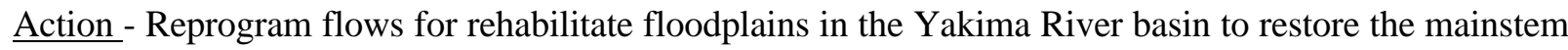
habitat there.

Action - Remove tributary dams with low hydro potential that have no anadromous fish passage, but do have habitat potential.

\section{The Following List of Actions Were also Discussed But Did not Meet the Stated Objective of Restoring Riverine Habitat:}

Action - Transport all juvenile migrants until it is proven that in-river passage yields higher returns or dams are removed or made safe for fish passage (i.e., $95 \%$ project survival).

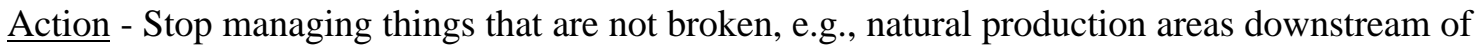
Bonneville Dam.

Action - Eliminate harvest in alternate years. When harvesting, select hatchery stocks to the exclusion of wild fish using terminal fisheries and live catch methods (weirs, fish wheels, seines, but not gill nets).

Action - Establish wild basins for restoration of wild stocks. Eliminate hatchery programs that do not meet the $80 \%$ wild fish survival standard.

Action - Put in place a biotic management program focused on trapping and removing predators that are immigrating into major tributaries from breached and drawdown pools. This would be an experimental project with pre- and post-breaching evaluation and continued if deemed necessary and effective. 